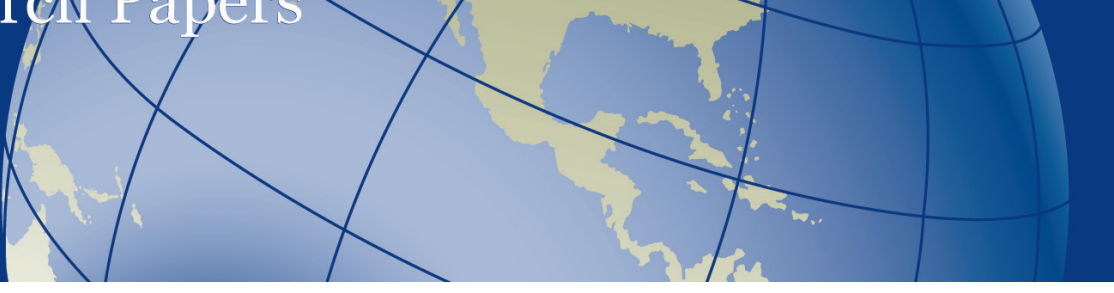

\title{
RISKY BUSINESS: THE ISSUE OF TIMING, ENTRY AND PERFORMANCE IN THE ASIA-PACIFIC LNG MARKET ${ }^{*+}$
}

\author{
M.C. Moore, D. Hackett, L. Noda, J. Winter, R. Karski and M. Pilcher \\ The School of Public Policy
}

\section{SUMMARY}

Canada's federal government has championed the prospect of exporting liquefied natural gas (LNG) to overseas markets. The government of British Columbia is aggressively planning to turn itself into a global LNG-export hub, and the prospect for Canadian LNG exports is positive. However, there are market and political uncertainties that must be overcome in a relatively short period of time if Canada is to become a natural gas exporter to a country other than the United States. This report assesses the feasibility of Canadian exports and examines the policy challenges involved in making the opportunity a reality.

Demand for natural gas in the Asia-Pacific region is forecast to grow over 60 per cent by 2025. LNG trade is expected to make up nearly two-thirds of global natural gas trade by 2035. Supply in the Asia-Pacific region is limited, requiring significant LNG imports with corresponding infrastructure investment. This results in substantial price differentials between North America and the Asia-Pacific countries, creating a potentially lucrative opportunity for Canada.

The lower North American prices are a reflection of the fact that there is a surplus of gas on this continent. Canada's shipments to its sole export market, the United States, are shrinking in the face of vast increases in American production of shale and tight gas. Canada has a surplus of natural gas and there is growing demand in the Asia-Pacific region. Proponents argue that all Canada needs to do is build and supply facilities to liquefy gas and ship it across the Pacific; the reality is not so simple.

Timing is one of the key challenges Canada faces. Producers around the world - including in the newly gas-rich U.S. - are racing to lock up market-share in the Asia-Pacific region, in many cases much more aggressively than Canada. While this market is robust and growing, the nature of the contracts for delivery will favour actors that are earliest in the queue; margins for those arriving late will be slimmer and less certain over time. As supply grows, so too does the likelihood of falling gas prices in the Asia-Pacific region, making later projects less lucrative. LNG projects are feasible only on the basis of long-term contracts; once a piece of market share is acquired, it could be decades before it becomes available again. Currently, there are more proposed LNG-export projects around the world than will be required to meet projected demand for the foreseeable future.

Delays beyond 2024 risk complete competitive loss of market entry for Canadian companies. B.C. is behind schedule on the government's goal of having a single terminal operational by 2015. Of equal concern is the lack of policy and regulatory co-ordination, with disagreements between governments over standards, process and compensation for those stakeholders involved in the potential LNG industry. Issues as basic as taxing and royalty charges for gas shipments between provinces and locating facilities and marine-safety standards remain unsettled in Canada. The B.C. government has announced plans to levy special taxes on LNG, a policy that could render many current proposals uncompetitive.

The LNG market is much more complicated than current discussions suggest; this report delves into every aspect relevant for Canada as a potential exporter. The prospect for Canada expanding into the Asia-Pacific market is entirely viable. Canada has almost everything going for it: political stability, free-market principles, immense resources, extensive infrastructure and industry experience. Everything, that is, except a co-ordinated regulatory and policy regime. Without that, Canada could be shut out, stuck relying on a single U.S. gas-export market that, increasingly, does not need us.

This research was financially supported by the Government of Canada via a partnership with Western Economic Diversification

The authors wish to acknowledge the helpful comments of the anonymous referees. The authors would also like to thank Brian Conger and Stephanie Symonds for excellent research assistance. 


\title{
UN PARI RISQUÉ : L'ENJEU DE LA CONJONCTURE, DE L'ACCĖS ET DU RENDEMENT DANS LE MARCHÉ DU GNL DE LA RÉGION ASIE-PACIFIQUE* ${ }^{*}$
}

\author{
M.C. Moore, D. Hackett, L. Noda, J. Winter, R. Karski et M. Pilcher,
}

École de politiques publiques

\section{RÉSUMÉ}

Le gouvernement fédéral du Canada a encouragé l'exportation de gaz naturel liquéfié (GNL) dans les marchés étrangers. Le gouvernement de la Colombie Britannique s'emploie activement à devenir un pôle d'exportation mondial de GNL, et la perspective est encourageante pour les exportations de GNL du pays. Cependant, le Canada devra surmonter relativement rapidement certaines incertitudes commerciales et politiques s'il veut exporter du gaz naturel ailleurs qu'aux États Unis. Les auteurs du présent rapport évaluent la faisabilité des exportations canadiennes et examinent les défis stratégiques à relever en vue d'atteindre cet objectif.

On prévoit que la demande en gaz naturel dans la région Asie-Pacifique croîtra de plus de 60 pour cent d'ici 2025. Le commerce du GNL devrait constituer près des deux tiers du commerce mondial du gaz naturel d'ici 2035. La région Asie-Pacifique, dont l'approvisionnement en gaz naturel est limité, nécessitera d'importantes importations de GNL et des investissements en infrastructure pour les acheminer. II en résultera des écarts de prix substantiels entre l'Amérique du Nord et les pays d'AsiePacifique, créant ainsi un débouché potentiellement lucratif pour le Canada.

La baisse des prix nord-américains correspond aux excédents de gaz naturel pour ce continent. Les livraisons du Canada vers son seul marché d'exportation, les États Unis, diminuent en raison des vastes augmentations de la production américaine de gaz de schiste et de gaz de formation imperméable. Le Canada possède des excédents de gaz naturel, une ressource qui fait de plus en plus défaut dans la région Asie-Pacifique. Certains soutiennent que le Canada n'a qu'à construire et à approvisionner des installations afin de liquéfier le gaz et de l'expédier à travers l'océan Pacifique; la réalité n'est pas si simple.

L'une des principales difficultés pour le Canada consiste à profiter de la conjoncture pendant qu'elle est encore favorable. Les producteurs du monde entier - dont les États Unis, devenus récemment riches en gaz - se disputent les parts de marché dans la région Asie-Pacifique, souvent bien plus activement que le Canada. Ce marché est vigoureux et en pleine croissance, mais il faut savoir que les contrats de livraison reposent sur la règle du « premier arrivé, premier servi » : les marges de profit des retardataires seront donc plus minces et moins sûres au fil du temps. Plus l'offre augmentera, plus les prix du gaz risqueront de diminuer dans la région Asie-Pacifique, ce qui réduira la rentabilité des projets lancés tardivement. Les projets de GNL ne sont possibles que dans le cadre de contrats à long terme; par conséquent, un concurrent qui accapare une part du marché pourrait la conserver pendant des décennies. Par ailleurs, à l'heure actuelle, l'offre cumulée des projets d'exportation de GNL proposés dans le monde dépasse la demande projetée pour un avenir prévisible.

Si le Canada tarde à agir d'ici 2024, les entreprises canadiennes risquent de perdre tout accès concurrentiel au marché. Or, on sait déjà que le gouvernement de Colombie-Britannique n'arrivera pas à se doter d'un terminal opérationnel en 2015, comme prévu. À cela s'ajoute l'absence de coordination des politiques et des règlements, qui est tout aussi préoccupante; en effet, les gouvernements n'arrivent pas à s'entendre sur les normes, le processus et l'indemnisation pour les intervenants qui agiraient dans le secteur du GNL. C'est pourquoi des questions aussi fondamentales que la taxation et les redevances pour les livraisons de gaz entre les provinces, l'emplacement des installations et les normes en matière de sécurité maritime ne sont toujours pas réglées. En outre, le gouvernement de la Colombie-Britannique a annoncé son intention de percevoir des taxes spéciales sur le GNL, une politique qui enlèverait toute compétitivité à de nombreuses propositions.

Le marché du GNL est beaucoup plus compliqué que les discussions actuelles ne le laissent entendre; le présent rapport se penche sur l'ensemble des aspects pertinents pour le Canada, en tant qu'exportateur potentiel. La perspective d'accroître les exportations du pays dans le marché Asie-Pacifique est tout à fait viable, le Canada disposant de presque tous les atouts : une stabilité politique, des principes de libre marché, d'immenses ressources, de vastes infrastructures et une grande expérience dans ce secteur. II ne lui manque qu'une chose : un régime de politiques et de règlements coordonnés. Faute de quoi, ce nouveau débouché pourrait lui échapper, le laissant ainsi contraint d'exporter exclusivement son gaz aux États-Unis, un pays qui a de moins en moins besoin de nous.

Cette recherche a été soutenue financièrement en partie par le gouvernement du Canada via Diversification de l'économie de I'Ouest Canada.

Les auteurs tiennent à remercier les lecteurs critiques anonymes de leurs commentaires pertinents. Ils aimeraient également remercier Brian Conger et Stephanie Symonds, qui ont été d'excellents assistants à la recherche. 


\section{INTRODUCTION}

The goal of this report is to analyze the potential for future deliveries of Canadian natural gas ${ }^{l}$ to countries in the Asia-Pacific region, in terms of demand in those countries and the cost competitiveness of Canadian supply. By definition, this report creates a distinction between natural gas supplies sourced from Canadian provinces, and the physical system (liquefied natural gas, or LNG) used to transport them. This distinction is important because of the need for Canadian producers to gain access to domestic tidewater ports using new or repurposed pipeline systems, to gain access to sufficient capital for construction of new facilities, and to secure contracts for delivery of reliable quantities of natural gas.

In all of this, costs and benefits to Canadian citizens are at issue, as are political and regulatory relationships. While costs and benefits for Canadians are critical areas for discussion, the regulatory arena, where projects are approved or denied, is the appropriate place to evaluate those costs and benefits. ${ }^{2}$ We do not discuss these issues in this paper, other than by reference (such as the success or failure of permits for pipeline and port construction) where they are factored into our analysis in terms of cost and timing. We do not evaluate the effect of a new gas export industry on the economy either in terms of consumer impacts, government revenues, the land impacts on First Nations lands or the extension of those impacts on Aboriginal groups with and without treaty rights, although we acknowledge that the LNG industry will not develop until these issues are resolved. Our goal is to evaluate the demand for natural gas in the Asia-Pacific region, and assess the feasibility of Canadian exports relative to other competitors.

This report is divided into nine sections. Following the introduction, we provide in the second section a brief overview of LNG pricing and contracts, supplies from Canada, and expected demand in the Asia-Pacific region. Third, we provide further detail on the structure of global LNG markets. Fourth, we detail demand for natural gas and LNG in the Asia-Pacific region. Fifth, we outline Canada's competitors in supplying LNG to Asian markets. Sixth, we discuss Canada's potential as an LNG supplier, including a discussion of expected costs. Seventh, we discuss the nature of risk in LNG markets. In the eighth section, we detail the policy implications of an LNG industry expansion in Canada, and draw final conclusions in section nine.

The value of this report lies in examining the dynamic public policy prescriptions in Canada in the context of the competitive role of Canadian natural gas exports. Ultimately, in order to access Asia-Pacific markets, new policies dealing with interprovincial infrastructure agreements, environmental standards, tariffs and taxes, and rights of way, must be developed, all in the context of timely access to markets for Canadian gas supplies. This report also points out the need for consistent policies and guidelines for tidewater-port choice and development standards.

\footnotetext{
1 We use dry gas as a reference point; natural gas with liquids (NGL) commands a higher price currently, but market circumstances for that commodity are currently in a state of flux and consequently we cannot estimate the role of NGLs in a future Asia-Pacific market. See Appendix B for details on natural gas characteristics.

2 Before the National Energy Board (NEB) grants export permits, it must formally assess and determine that impacts on Canadian domestic service are fully mitigated and will not result in significant price impacts (See section 6.2 for details).
} 
The expansion of shale gas production in Canada and the United States has created opportunities to export LNG from both countries. This is reflected in the current price differential between Asian importing countries and the wellhead price for gas in North America. Overall, demand in the Asia-Pacific region is forecast to grow approximately 4.4 per cent a year to $2025 .^{3}$

The risks and rewards represented by entry into the LNG market in the Asia-Pacific region are substantial. Surplus Canadian natural gas, not consumed domestically, is currently shipped exclusively to the United States, where market prices are low and projected to remain so for the foreseeable future. This problem of persistently low prices is amplified by the increasing development of shale gas and other unconventional sources ${ }^{4}$ in the United States, leading to declining shares in one of Canada's traditional markets. ${ }^{5}$ Since the current price for natural gas in the Asian market reflects robust and growing demand, finding shipping access to this market commands a high priority.

There is a wide range of risks associated with developing this market, from public or environmental quality to potentially misdirecting capital assets. A key element of risk is that of the final price, which will naturally fluctuate over time with changes in supply and demand balances. While the return on investment depends on both the capital cost and the margin between delivered price and variable costs, a margin as low as US \$4/MMBTU (\$3.79/GJ) can still result in a pre-tax rate of return above 10 per cent for projects with relatively low capital costs.

A great deal of regulatory and policy co-operation and co-ordination is required to gain permission to build necessary facilities and convince demand sources and potential investors of the reliable and consistent delivery of gas from Canada in order to capture viable market shares. The role of the various actors is important in this arena since, ultimately, the business community develops and serves new markets and raises the necessary capital for investment.

However, there are many proposed liquefaction projects around the world and the longer Canadian projects take to move forward, the more likely it becomes that Canadian supplies will be displaced by these other projects. The capital requirements to build these facilities mean long-term contracts are necessary to obtain adequate financing; delays mean contracts from Asian countries will be signed with other suppliers.

Thus, it is difficult to overstate the importance of acting before the equivalent market share is acquired by competitive nations and companies with price levels and contract commitments that represent costs of delivery below Canadian delivered resources. A race to the bottom risks diversion and stranding of capital assets that might not be readily re-deployed. The advantage of a consistent and timely plan for entering the market is represented by a combination of longterm resource delivery contracts, as well as a strong industry investment domestically.

3 BP, BP Energy Outlook 2030 (2013).

4 "Unconventional gas" is an umbrella term used to describe production of natural gas that does not meet the criteria for conventional gas production - production where geological pressure, reservoir and fluid characteristics are sufficient for the resource to flow to the surface - that is a function of resource characteristics and available technology, among other things. Further details are available in Appendix D (Definitions and Glossary).

5 In the past five years, there has been a shift from western Canadian gas being exported to the Eastern U.S. via Eastern Canada, to natural gas from the Eastern U.S. supplanting western Canadian gas in supplying Eastern Canada. 


\section{OVERVIEW AND BACKGROUND}

There is no demand for LNG per se; there is only demand for natural gas. LNG is simply natural gas cooled to a liquid state at $-162^{\circ} \mathrm{C}$ so that it can be transported in ships across oceans to markets where the demand for natural gas exceeds the supply of natural gas from local sources. It is therefore useful to put the "demand" for LNG in context with the demand for natural gas. In 2012, global natural gas consumption (demand) was about 3,300 billion cubic metres (BCM), equivalent to 117 trillion cubic feet (TCF) or 9 billion cubic metres per day (BCM/d). ${ }^{6}$ Global demand (total imports) for LNG in 2012 was about 240 million tonnes (MMT), equivalent to about $330 \mathrm{BCM}$ of natural gas.? Hence, the global demand for LNG, natural gas in liquid form, represents only 10 per cent of the total global demand for natural gas.

Natural gas provides about one-fifth of the world's primary energy supplies. About 70 per cent of global gas production is consumed in the country where it is produced, and about 30 per

\section{NATURAL GAS UNITS OF MEASUREMENT}

The unit of measure for natural gas and LNG is not standardized across or within countries. Natural gas is often measured by volume - cubic metres (CM) or cubic feet (CF) - or by heat content: joules $(J)$ or British thermal units (BTU). In contrast, LNG is often measured by its mass (tonnes).

Terms used inconsistently and often interchangeably in the gas and LNG market include:

\section{VOLUME AND COMBUSTION UNITS}

$\mathrm{MCM} \quad=$ thousand cubic metres

$\mathrm{MCM} / \mathrm{BCM} / \mathrm{TCM}=$ million/billion/trillion cubic metres

MMCM $=$ million cubic metres

$\mathrm{MCF} / \mathrm{BCF} / \mathrm{TCF}=\mathrm{million} / \mathrm{billion} /$ trillion cubic feet

MT/MMT $=$ million (metric) tonnes

MBTU/MMBTU $=$ million British thermal units

$\mathrm{PJ} / \mathrm{GJ} / \mathrm{MJ} / \mathrm{J}=$ petajoule $/$ gigajoule $/$ megajoule $/$ joule

\section{RATE UNITS}

MTPA $=$ million (metric) tonnes per annum

MMTPA $\quad=$ million (metric) tonnes per annum

$\mathrm{CF} / \mathrm{d} \quad=$ cubic feet per day

$\mathrm{CM} / \mathrm{d}=$ cubic metres per day

Additional details on units and conversion rates are available in Appendix D.

In this paper, the primary unit of measurement for natural gas is cubic metres (CM). For LNG, we will measure in tonnes $(T)$. For facility capacity, the unit is tonnes per annum (TPA). For prices, as BTU is the international standard, we will use U.S. dollars per MMBTU, and also report dollars per GJ. In all cases, million will be represented by MM. cent of global gas production is exported across international borders. In 2012, about 1,030 BCM of natural gas was exported, of which about $700 \mathrm{BCM}$ was exported through cross-border pipelines, while about $330 \mathrm{BCM}$ (32 per cent) was transported in the form of LNG. ${ }^{8}$ Figure 2.1 shows major natural gas trade flows via pipeline and LNG for 2012 .

6 BP, BP Statistical Review of World Energy 2014 (2014), http://www.bp.com/en/global/corporate/about-bp/energyeconomics/statistical-review-of-world-energy.html.

7 BP, BP Statistical Review of World Energy 2014

8 BP, BP Statistical Review of World Energy 2014 
FIGURE 2.1: MAJOR NATURAL GAS TRADE MOVEMENTS IN 2012 (BCM)

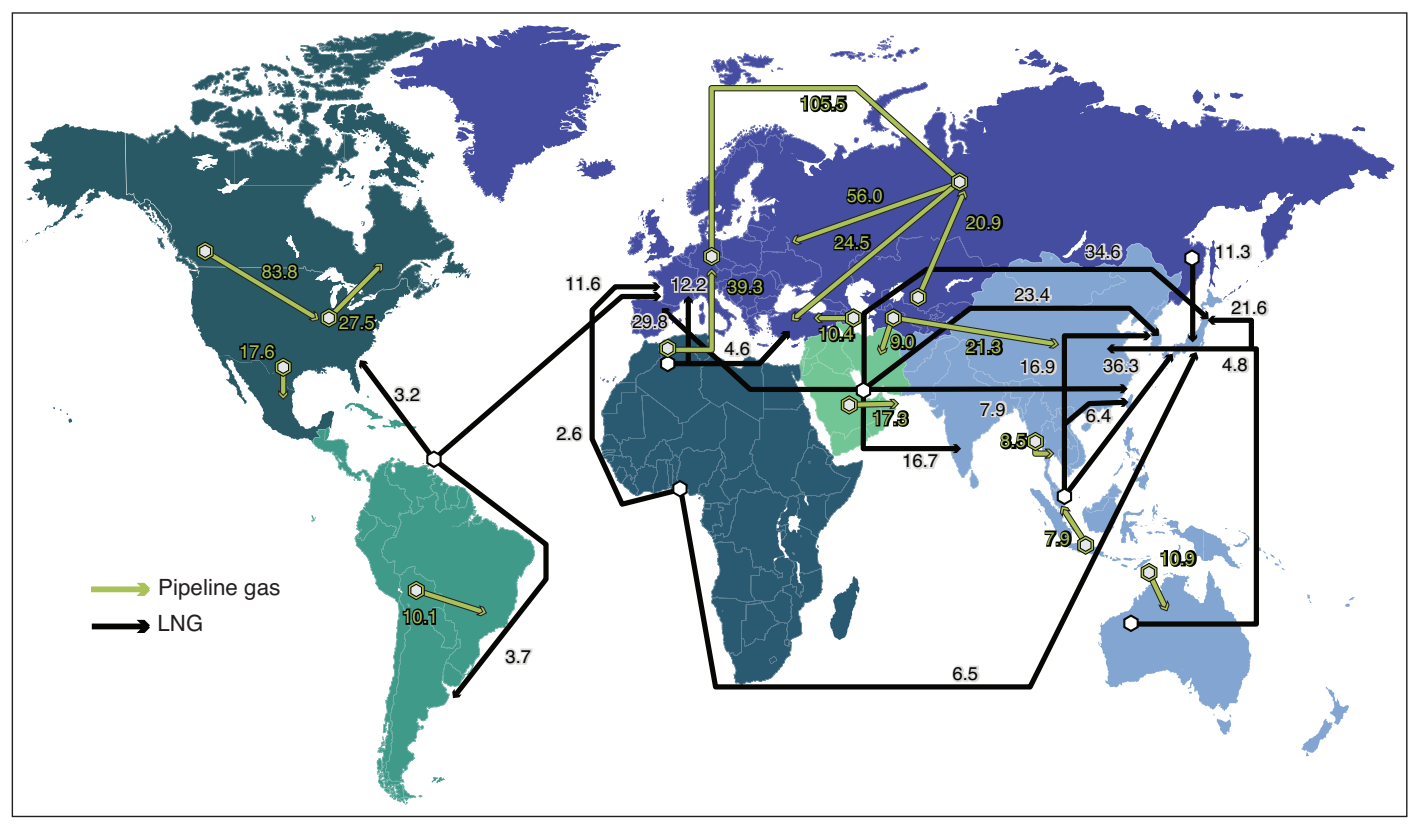

Notes: The above figure does not show minor trade movements, such as imports to the Canaport facility in Saint John, N.B. According to National Energy Board (NEB) data, Canaport import volumes peaked at 3.35 BCM in 2011, and were 1.71 BCM in 2012, 49 per cent from Trinidad and Tobago and 51 per cent from Qatar.

Source: BP, BP Statistical Review of World Energy June 2013 (2013).

In North America, Canadian sedimentary basins and more recently developed shale deposits (see Figure 2.5, below) supported a large fraction of U.S. demand and Canadian interprovincial domestic needs. ${ }^{9}$ Around 2008, U.S. domestic production increased, leading to diminished demand for Canadian gas and, in the case of Eastern Canada, reversed flows.

The availability of Canadian gas is increasing, based on technological improvements allowing access to unconventional shale and tight gas plays. Given the reality of lower demand for Canadian gas in the continental U.S., a key to the economic development of Canada's natural gas resources lies in gaining tidewater access using LNG facilities and shipping. This potential export market is evolving rapidly as other nations also work to develop export capacity. While the National Energy Board has issued export permits for many proposed projects in B.C., ${ }^{10}$ this is but one step of many. A lengthy regulatory process for site permitting and supply pipelines has the potential to delay projects to the point where there is no market to supply. Appearances of policy and regulatory uncertainty will affect access to financing, another potential source of project failure. Much of the success of future development for Canadian exports of natural gas will depend directly on development of adequate tidewater-port capacity that will serve national as well as provincial interests, and ultimately involve Aboriginal as well as public land holdings.

9 Additional details on historical Canadian natural gas markets are available in Sections 6.1 and 6.2.

10 National Energy Board website, "LNG Export License Applications," http://www.neb-one.gc.ca/clfnsi/rthnb/pplctnsbfrthnb/lngxprtlencpplctns/lngxprtlcncpplctns-eng.html\#s2 . 
There are substantial rewards, both public and private, to overcoming challenges and expanding this sector, including diversifying the Canadian energy economy. Lack of natural gas export infrastructure in North America, combined with increased production, has led to natural gas prices in Canada and the U.S. being lower than those in other markets. Natural gas has been promoted as a "bridge fuel" that allows the transition away from carbon-intensive energy sources. ${ }^{l l}$ Its advantage is most apparent in terms of energy density, ease of transfer, storage stability and comparatively attractive environmental impacts in terms of carbon emissions from combustion. ${ }^{12}$ Power systems based on natural gas are beginning to displace older, less-efficient thermal combustion, such as coal. There is some early indication that compressed natural gas $(\mathrm{CNG})$ and passenger-vehicle use of natural gas may increase. Some demand growth for natural gas liquids has been appearing and some chemical industries based on natural gas are coming back onshore. In short, both domestically and internationally, natural gas markets are seen as having great growth and revenue potential.

Overall, natural gas demand has increased in developed as well as developing countries. For instance, in 2012, for the first time, South America imported a larger volume of LNG compared to North America, a reflection of increased demand in South America as well as growing self-sufficiency in the United States from domestic gas supplies and its subsequent curtailment of imports. Simultaneously, the Asia-Pacific region has been reaching as far away as the Middle East and Africa to satisfy growing import demands. Natural gas demand in Japan and South Korea is supplied by waterborne LNG because there are no pipeline connections to producing regions. All (current and future) LNG exporters benefit from limited pipeline networks in the Asia-Pacific region.

Challenges facing entrants to the Asia-Pacific market, however, are formidable if the full potential of serving this market is going to be achieved. This includes the cost of new facilities or upgrading/modifying existing facilities, in addition to securing project financing and contracts with countries in the region. Investment in these new markets is attracting established exporters who can target new capacity to growth areas in these countries and dominate the emerging marketplace. Since Canada may arrive late ${ }^{13}$ to this market, the key challenge is to obtain contract agreements as early as possible, with firm commitments to production and access through accessible and safe port facilities.

Additionally, the rapid increase of both exporters and new import facilities has dramatically increased the complexity of the market and created price pressures for the existing trading-price system. For example, LNG importers are pushing for contracts linked to North American prices (currently much lower than Asian pricing points) rather than the traditional oil-linked prices.

11 Christina Nunez, "Can Natural Gas Be a Bridge to Clean Energy?" National Geographic, March 18, 2014, http://environment.nationalgeographic.com/environment/energy/great-energy-challenge/big-energy-question/cannatural-gas-be-a-bridge-to-clean-energy/.

12 Natural gas power generation produces lower levels of NOx, SOx and particulates than does other thermal electric generation such as coal. Transitioning from hydrocarbons, such as coal, requires consistent policy support ranging from subsidies for preferred fuels to environmental standards and enforcement - literally a bridge from current to future energy systems.

13 Other projects appear to be moving faster in securing contracts and proceeding to a final investment decision. U.S. Gulf Coast projects have a cost advantage from converting regasification facilities to liquefaction; while they are further from Asia than is the B.C. coast, the U.S. projects have the potential to supply Europe, which would divert cargoes from suppliers such as Qatar, which supplies both Asia and Europe. 
Additional challenges specific to Canada include:

- Some uncertainty in domestic reserves based in unconventional supplies, adding risk to new import facility investment.

- Potential new supplies from the Gulf Coast region will offer new challenges in terms of price competition and volume.

There are associated opportunities in these markets as well including:

- Arbitrage opportunities based on large price differentials between North America and AsiaPacific countries.

- The demand for new LNG deliveries has helped drive the development of a more modern shipping fleet, with safer operating characteristics and large average volume per trip.

\subsection{Pricing and Contracts}

In the United States and Canada, the price of natural gas is set in competitive markets based on many variables including overall supply and demand, production and exploration levels, storage injections and withdrawals, weather patterns, pricing and availability of competing energy sources and market participants' views of future trends in any of these or other variables. Monthly natural gas demand (and prices) tends to fluctuate due to changes in wholesale natural gas prices that, in turn, reflect seasonal demand for heating and power generation (with corresponding twin peaks in winter and summer) and industrial base-loads.

Natural gas trades on real-time (spot) markets as well as futures markets on exchanges such as the New York Mercantile Exchange (NYMEX). The NYMEX natural gas futures contracts are widely used as an international benchmark price and have been used in conjunction with oil prices as a core index of value. ${ }^{14}$ Natural gas prices in North America reflect an integrated supply-and-demand network, and are linked through an integrated North American marketplace and pipeline system where the price of natural gas is largely determined based on supply and demand.

The physical nature of natural gas makes it less fungible than oil. As a result, regional markets have developed, each with their own pricing point and energy-content characteristics. ${ }^{15}$ These pricing points, or hubs, reflect physical manifolds or redistribution of gas to other regional markets or storage points. The most common price point is at the Henry Hub in Louisiana; it lends its name to the pricing point for natural gas futures contracts traded on the NYMEX, and the over-the-counter swaps ${ }^{16}$ traded on the Intercontinental Exchange (ICE). The pricing arrangements are for spot as well as futures for most of the world, although there are other hub and transfer points, such as AECO in Alberta, where a price quote can be derived.

${ }^{14}$ Gas futures contracts trade in units of 10,000 million British thermal units (MMBTU). The price is based on delivery at the Henry Hub in Louisiana, the centre of 16 intrastate and interstate natural gas pipeline systems that draw supplies from the region's prolific gas deposits. The pipelines serve markets throughout the U.S. East Coast, Gulf Coast and Midwestern U.S.

15 For an overview of different world pricing mechanisms, see: The Pricing of Internationally Traded Gas, ed. J. Stern (Oxford: Oxford University Press, 2012).

16 In this context, a commodity swap is a contract or agreement whereby a floating (market or spot) price is traded for a fixed price over a specified period. 
Most Canadian gas is sourced from Alberta (with a significant future supply likely to come from Northeast British Columbia). This gas is traded at the AECO hub, where the AECO "C" spot price provides a differential benchmark to Henry Hub pricing in the United States. Although Henry Hub pricing is a reference standard, it is not ubiquitous worldwide, and primarily serves as a norm in the U.S.

Monthly natural gas prices for major global pricing points are shown in Figure 2.2; there is clearly regional variation and substantial volatility in the prices shown. Henry Hub and AECO move together, tied by the North American pipeline network. Most interesting is the divergence in North American prices from the other three series near the end of 2008. The financial crisis led to the fall in prices worldwide, and production from newly accessible unconventional gas plays kept prices low in North America while other regions recovered. Shortfalls in North Sea fields have begun to appear in recent periods for natural gas supplied to the U.K. market. The dramatic increase in gas demand in Japan following the Fukushima nuclear disaster has driven a resurgence of interest in LNG in the Asia-Pacific region, a shift that may continue far into the future.

FIGURE 2.2: MONTHLY GLOBAL GAS PRICES 2004 - 2013

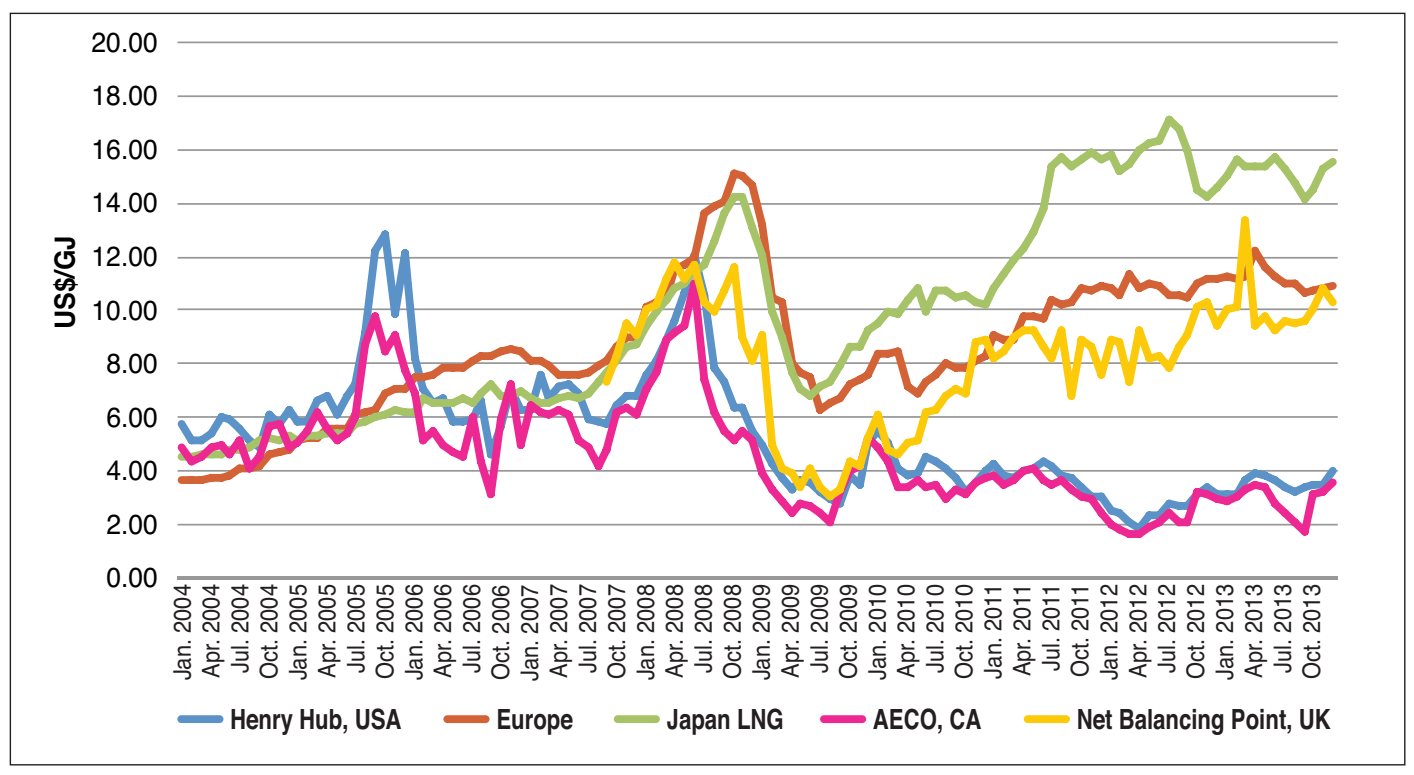

Notes: The Europe price is composed of the average import border price and a spot price component, beginning April 2010 including the U.K.; during June 2000 - March 2010, prices exclude the U.K.

Source: World Bank Commodity Price Data (Henry Hub, Europe, Japan LNG); Bloomberg (AECO, NGCDAECO; UK Net Balancing Point, NBPGWTHN).

In contrast to North America, gas markets in the Asia-Pacific region are dominated by longterm contracts with the LNG price linked to the price of oil. ${ }^{17}$ The reason for oil-linked prices is historical - Japan's contracts in the 1970s had LNG linked to oil prices, as those were the two main fuels used in power generation. ${ }^{18}$ Long-term contracts have three components: the oil

\footnotetext{
17 Jonathan Stern, "International gas pricing in Europe and Asia: A crisis of fundamentals," Energy Policy 64, 1 (2014): 43-48.

18 Stern, "International gas pricing."
} 
price benchmark, the "price slope," and a fixed term. ${ }^{19}$ The most common oil price benchmark used is Japan Customs-cleared Crude (JCC), and the fixed term is generally related to shipping costs. The main focus of contract negotiations between buyers and sellers is the indexation to oil - known as the "price slope" - which determines the extent to which the LNG price changes in response to a change in the price of crude oil. Ernst and Young notes that the contract slope is usually around 14 or 15 per cent, slightly lower than the heat equivalence between a barrel of oil and 1 million BTUs of natural gas. ${ }^{20}$ In addition, some contracts adjust the slope percentages at different oil prices. One such example is a contract that has a flatter slope at lower oil prices to protect sellers and a flatter slope at higher oil prices to protect buyers, called an "S-curve." Other contract variations protect only the seller (via a lower limit on the oil price) or only the buyer (via an upper limit on the oil price). Figure 2.3 shows example contracts.

\section{FIGURE 2.3: EXAMPLE LNG CONTRACT SLOPES}

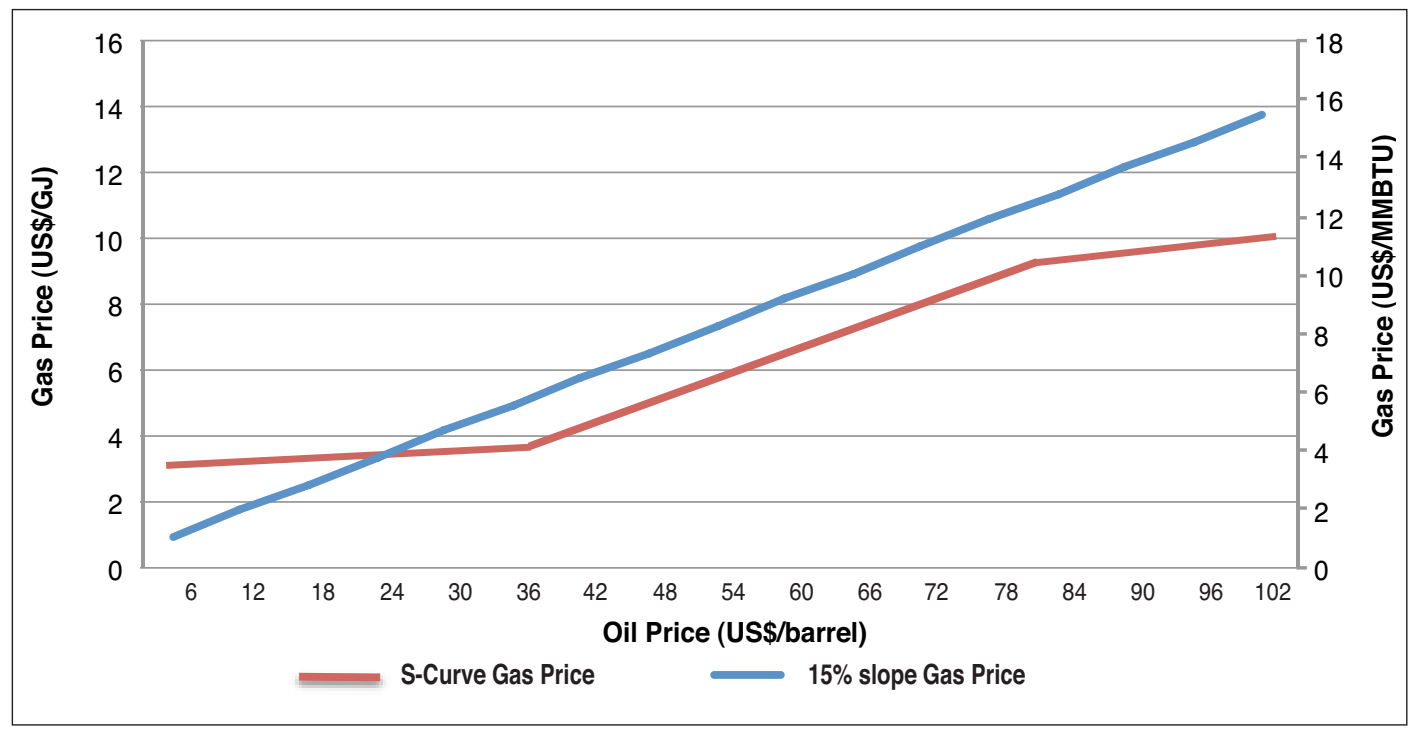

A consequence of the gas boom in Canada and the U.S. is the rash of proposals to export LNG from Canada's West Coast, the U.S. Gulf Coast and the U.S. West Coast. However, this has created a shakeup in the LNG pricing world for two reasons. The first is that Henry Hub is an alternative pricing point to JCC; the second is that new supplies have created additional competition previously lacking. ${ }^{21}$ The Sabine Pass project in the U.S. Gulf Coast entered into contracts with Asian buyers in 2011 and 2012 on a "Henry Hub-plus" basis. ${ }^{22}$ With a large price differential between Henry Hub and Asian price points, it is no surprise that Asian buyers appear eager for Henry Hub-linked prices rather than the traditional oil-linked contracts.

\footnotetext{
19 Ernst and Young, "Global LNG: Will new demand and new supply mean new pricing?" (2013).

20 Ernst and Young, "Global LNG."

21 Stern, "International gas pricing."

22 Edward Klump and Rakteem Katakey, "Korea Gas to Buy U.S. LNG as Gas Slump Attracts Asian Importers," Bloomberg, January 30, 2012, http://www.bloomberg.com/news/2012-01-30/cheniere-agrees-to-sabine-pass-exportdeal-with-korea-gas-1-.html.
} 
FIGURE 2.4: ILLUSTRATIVE LNG PRICING OPTIONS: OIL-INDEXED VERSUS HENRY HUB-INDEXED

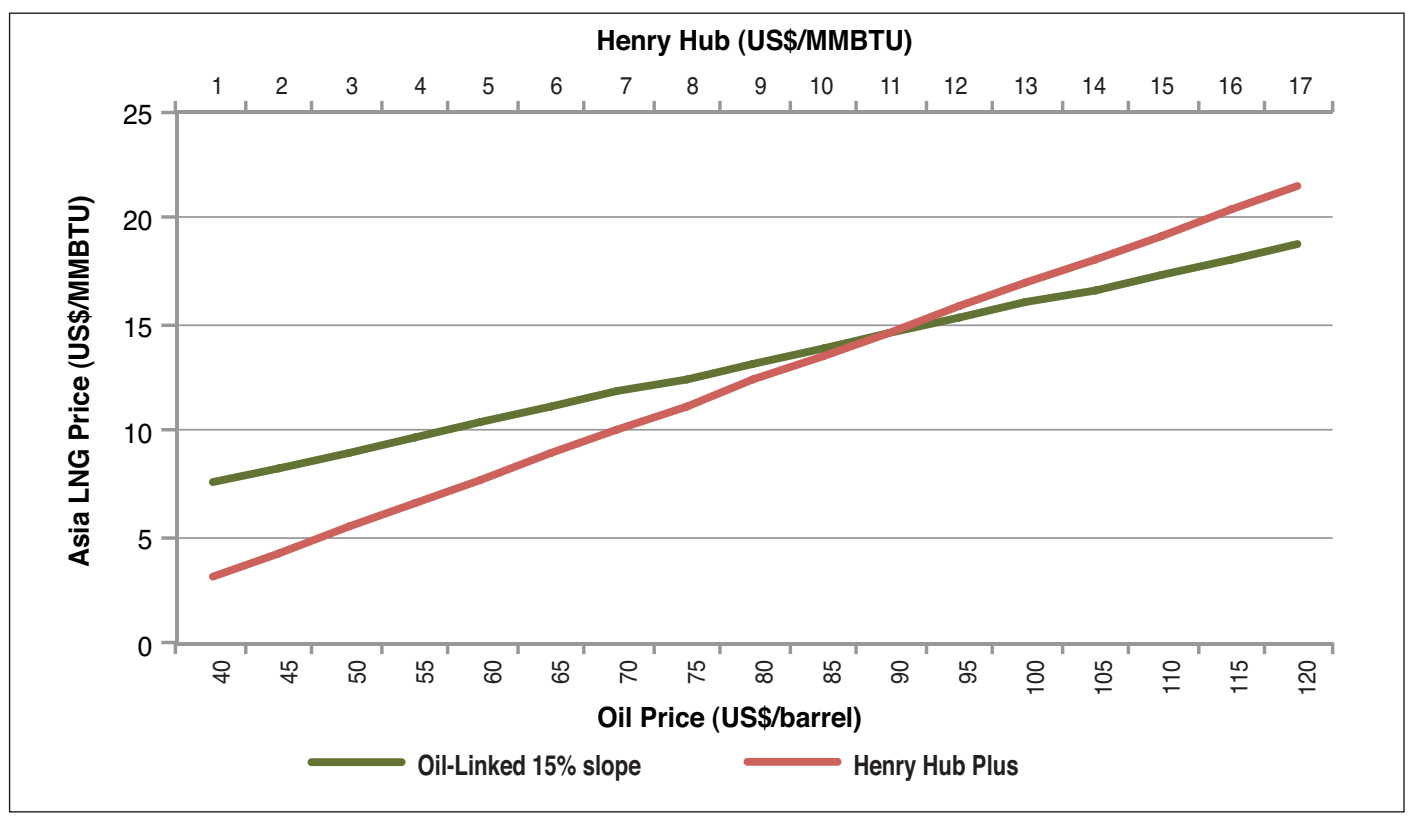

Note: The oil-linked price $=$ Oil $\times 0.15+2$. Henry Hub-plus $=H H \times 1.15+2$. Pricing formulas from: The Pricing of Internationally Traded Gas, ed. J. Stern (Oxford: Oxford University Press, 2012), Chapter 11, “LNG Pricing in Asia."

Figure 2.4 shows LNG pricing when it is indexed to oil prices and indexed to Henry Hub. We see from the figure that for oil prices below $\$ 90 \mathrm{USD} /$ barrel and Henry Hub prices below $\$ 11$ USD/MMBTU, a Henry Hub-indexed contract favours the buyer. However, as the slope on the oil-linked price decreases, the contract line becomes flatter, lowering the oil price where Henry Hub-plus is less than the oil-linked LNG price. Similarly, if the negotiated fixed component of the Henry Hub-plus contract increases to \$3 USD/MMBTU, the oil-linked contract is again more appealing to buyers.

\subsection{Canadian Gas Supply and Markets}

Canadian natural gas supplies are limited by the location of existing gas reserves in sedimentary basins and unconventional shale deposits, primarily in western provinces (Figure 2.5). These gas-producing regions are tightly locked to U.S. distribution and consumption centres in key ways, including existing long-term delivery contracts, existing infrastructure and a lack of export access points. Coastal tidewater access is limited, with few ports and overland access routes. 


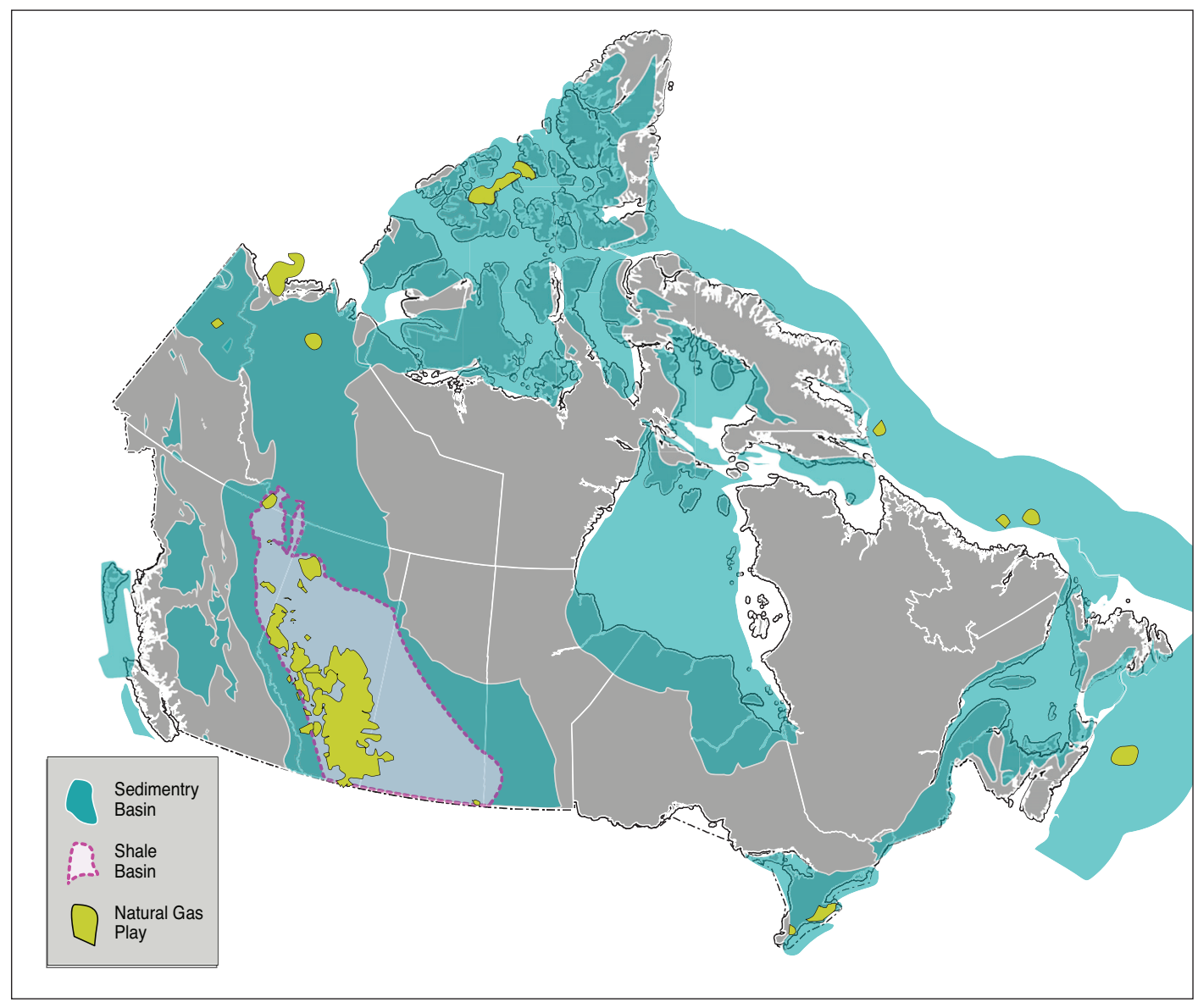

Source: Sedimentary Basins from Natural Resources Canada, "Crude Oil and Natural Gas Resources, 2006," map, http://atlas.gc.ca/site/english/maps/energy.html; Shale basins from U.S. EIA, "World Shale Gas Resources: An Initial Assessment of 14 Regions Outside the United States," April 2011.

Canadian gas has historically served two markets: exports to the United States and domestic use. The gas pipeline system in Canada and the U.S. is based around collection/distribution hubs that serve as pricing points, illustrated in Figure 2.6. While Henry Hub is the main North American pricing point, there are several additional sub-pricing points based on the location of the resource, and the pipeline system delivering product to demand centres. Representative gas flows are displayed in Figure 2.6. Historically, gas from the Western Canadian Sedimentary Basin has supplied Eastern Canada, the U.S. Midwest, and the U.S. West Coast. Since 2007, annual Canadian exports have been decreasing, while imports have been increasing since 2005. More details on historical markets are available in Section 6.1. 
FIGURE 2.6: REPRESENTATIVE NATURAL GAS HUBS AND TRADE FLOWS

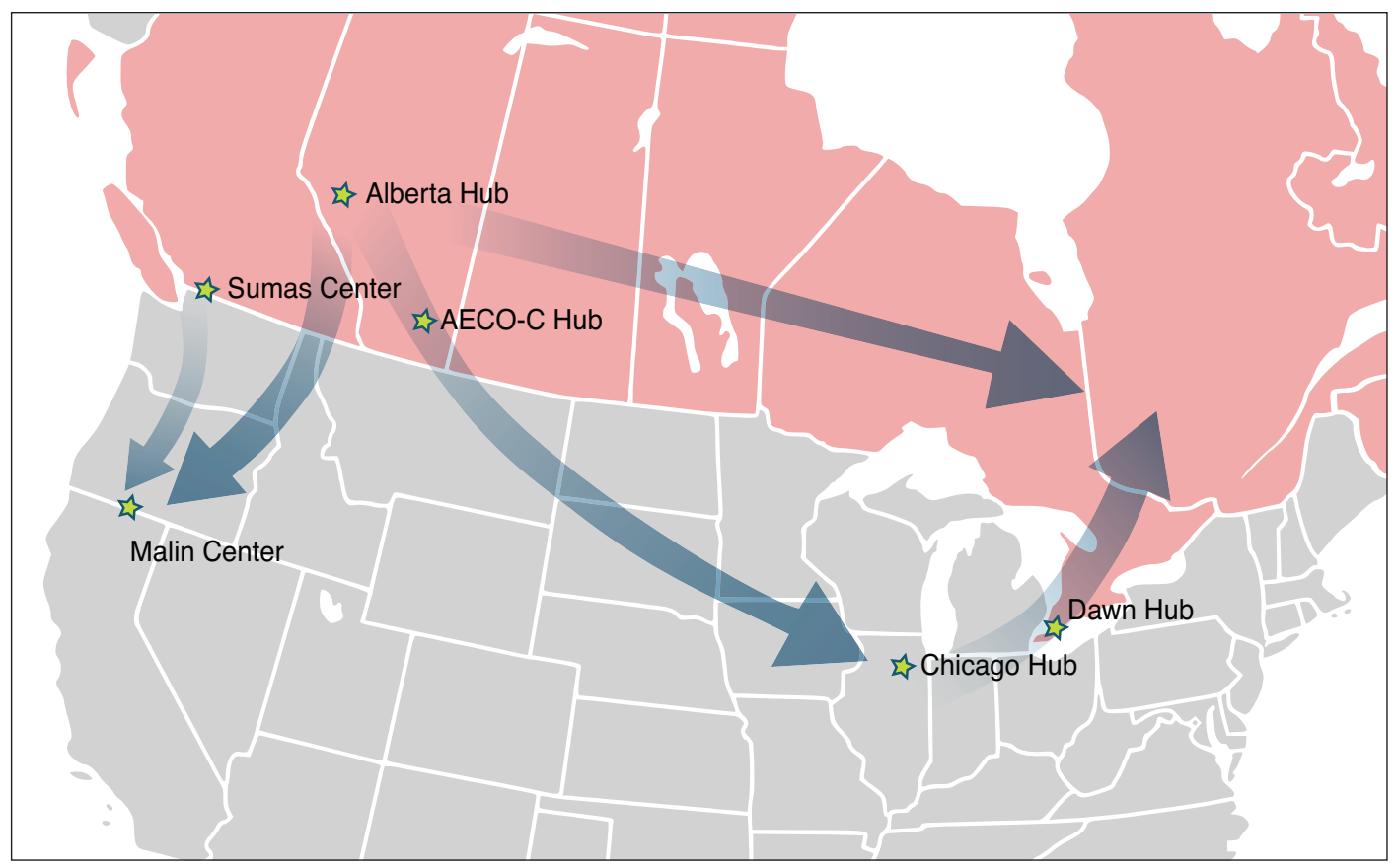

Source: Based on National Energy Board Commodity Statistics database, "Gas - Historical Summary by Port."

Net Canadian exports to the U.S. have fallen from the peak of $0.3 \mathrm{BCM}$ per day $(\mathrm{BCM} / \mathrm{d})$ in 2007 to $0.22 \mathrm{BCM} / \mathrm{d}$ in $2013 .{ }^{23}$ Bentek forecasts that this trend will continue, at least in the short term, with Canadian gas exports to the U.S. possibly falling as low as $0.09 \mathrm{BCM} / \mathrm{d}$ by $2018 .{ }^{24}$ Canadian gas production, as a consequence, has fallen from $0.6 \mathrm{BCM} / \mathrm{d}$ in 2000 to 0.5 $\mathrm{BCM} / \mathrm{d}$ in $2013 .^{25}$ The National Energy Board expects marketable gas production to decline to $0.32 \mathrm{BCM} / \mathrm{d}(11.2 \mathrm{BCF} / \mathrm{d})$ in 2018; from 2019 onwards, potential price increases and LNG exports would support more drilling, causing production to increase, reaching $0.49 \mathrm{BCM} / \mathrm{d}$ (17.4 BCF/d) in $2035 .^{26}$

Canadian gas producers are facing the slow collapse of gas exports to the U.S. The primary source of the decline can be found in the increase in U.S. shale gas production, coupled with the construction of new pipelines to deliver U.S. gas to U.S. domestic buyers. Newly accessible unconventional gas reserves are found widely throughout the U.S., and current costs of production create strong incentives to build new domestic pipeline facilities to gain access to this relatively inexpensive resource. In a unique and unexpected reversal, low-cost gas from the Marcellus is now being imported into eastern Canadian markets at Niagara Falls.

\footnotetext{
23 Authors' calculations from: Statistics Canada, CANSIM Table 131-0001, "Supply and disposition of natural gas."

24 Bentek Energy, LNG Exports: The Global Thirst for North American Shale Gas (Denver: Platts, 2013).

25 Authors' calculations from: Statistics Canada, CANSIM Table 131-0001, "Supply and disposition of natural gas."

26 National Energy Board, "Canada's Energy Future 2013: Energy Supply and Demand Projections to 2035 - Natural Gas Outlook Highlights," November 20, 2013, http://www.neb-one.gc.ca/clfnsi/rnrgynfmtn/nrgyrprt/nrgyftr/2013/fctshtntrlgs-eng.html.
} 
This represents a shift in terms and deliveries for the U.S. (Canada's sole export client) and, other than regional changes (Maine to Montreal and Atlantic Canada), a slow contraction of demand for Canadian gas. The loss of contracted flows from west to east on the TransCanada mainline reflects these changes domestically within Canada as well. ${ }^{27}$ In the absence of new export markets, it is probable that Canadian production will remain stagnant, serving only domestic and some U.S. demand.

Low domestic gas prices, linked with increased foreign demand, has stimulated interest in developing alternative methods of shipping Canadian gas to offshore markets, where prices are currently more robust than in Canada and the continental United States. Potential Canadian LNG terminal locations are illustrated in Figure 2.7.

There are currently 14 proposed liquefaction projects along the British Columbia coast, plus an additional two in Oregon that will be supplied by Canadian natural gas. Eleven of these projects have secured LNG export licences from the National Energy Board (NEB). ${ }^{28}$ The total approved export capacity is 183 MMTPA (249 BCM), compared to Canada's 2013 marketable natural gas production of $141 \mathrm{BCM}^{29}$

We have identified six zones for the proposed facilities on the B.C. coast, illustrated in Figure 2.7. In addition, there are seven natural gas pipelines planned to service the region, though the success of the pipelines will undoubtedly depend on the success of proposed LNG export facilities. Additional details on the proposed projects can be found in Section 6.3 and Appendix C.

\section{FIGURE 2.7: POTENTIAL LNG TERMINALS IN BRITISH COLUMBIA}

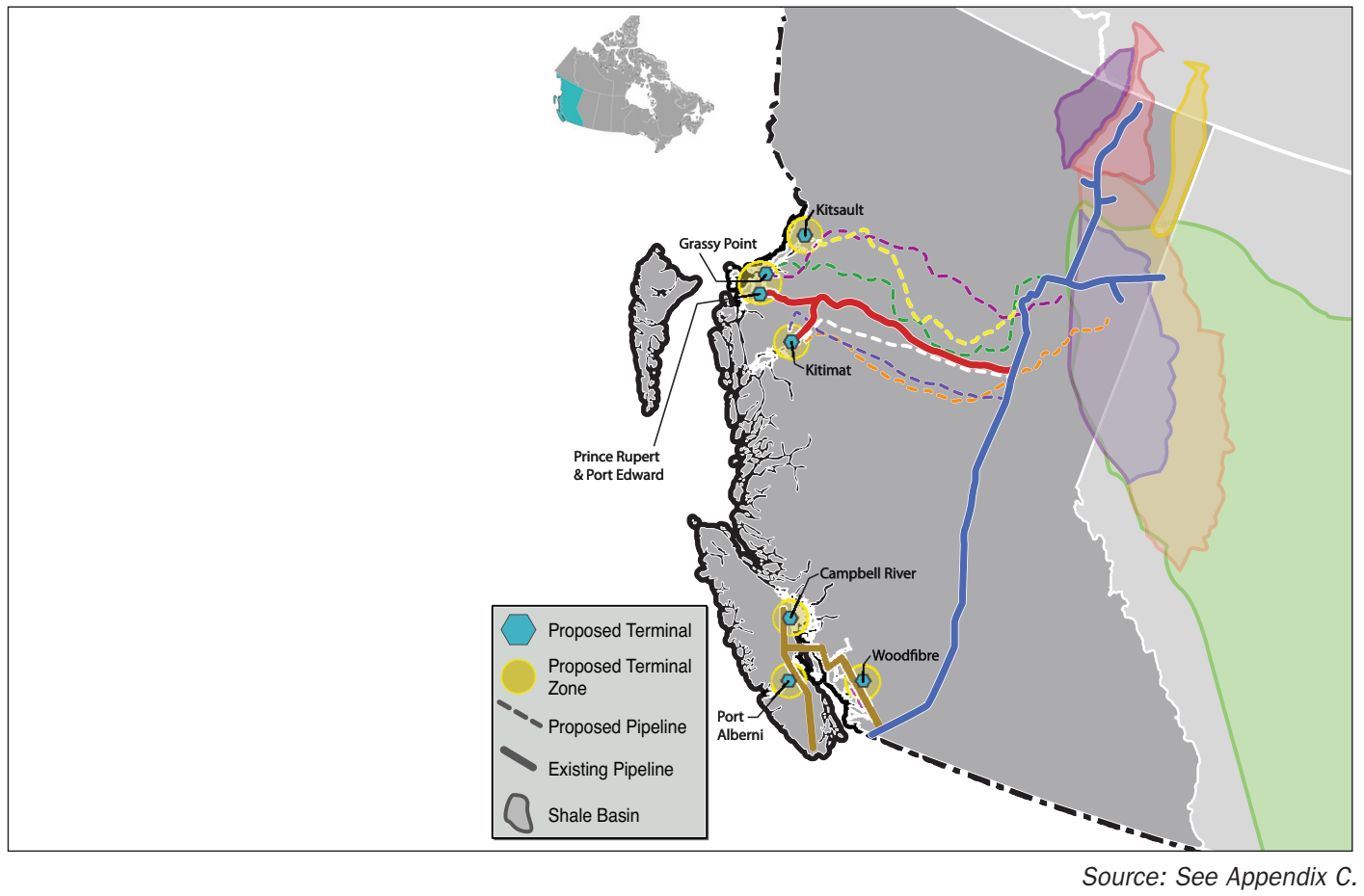

27 Darren Campbell, “TransCanada launches open season for mainline conversion," Alberta Oil, April 2, 2013, http://www.albertaoilmagazine.com/2013/04/transcanada-launches-open-season-for-mainline-conversion/.

28 Before the NEB grants export permits, it must formally assess impacts on Canadian domestic service and determine that they are fully mitigated and will not result in significant price impacts.

29 Authors' calculations, from CANSIM Table 131-0001. 


\subsection{Asia-Pacific Demand Overview}

The Pacific Basin is a term of art, variously used to describe the ocean area separating North America from Asia, but occasionally expanded to include the western areas of Central and South America and their trading ports in the Pacific Basin. For this report, we are concerned with the practical market opportunities for Canadian natural gas in the Northern Hemisphere of the Pacific Basin, broadly including Japan, China, Taiwan, South Korea, Indonesia and India.

One of the difficulties faced by exporters is the physical challenge of navigating narrow channels such as the Straits of

\section{DEFINING "ASIA-PACIFIC"}

The IEA defines the Asia-Pacific region as including $O E C D$ AsiaOceania (minus Israel), non-OECD Asia, and China. Alphabetically: Australia, Bangladesh, Brunei Darussalam, Taiwan (Chinese Taipei), India, Indonesia, Japan, Korea, Malaysia, Myanmar, New Zealand, Pakistan, China (including Hong Kong), the Philippines,

Thailand, Vietnam, and "other." Malacca, or a passage such as the Panama Canal. Speeds are reduced in these areas, safety is potentially at risk from collisions, and vessel size is constrained. Smaller ships influence the number of trips made to complete contracts and, while they do not strictly limit the potential to meet market demand, the constraints do influence the price floor for the commodity.

FIGURE 2.8: LNG IMPORTERS AND EXPORTERS IN THE PACIFIC BASIN

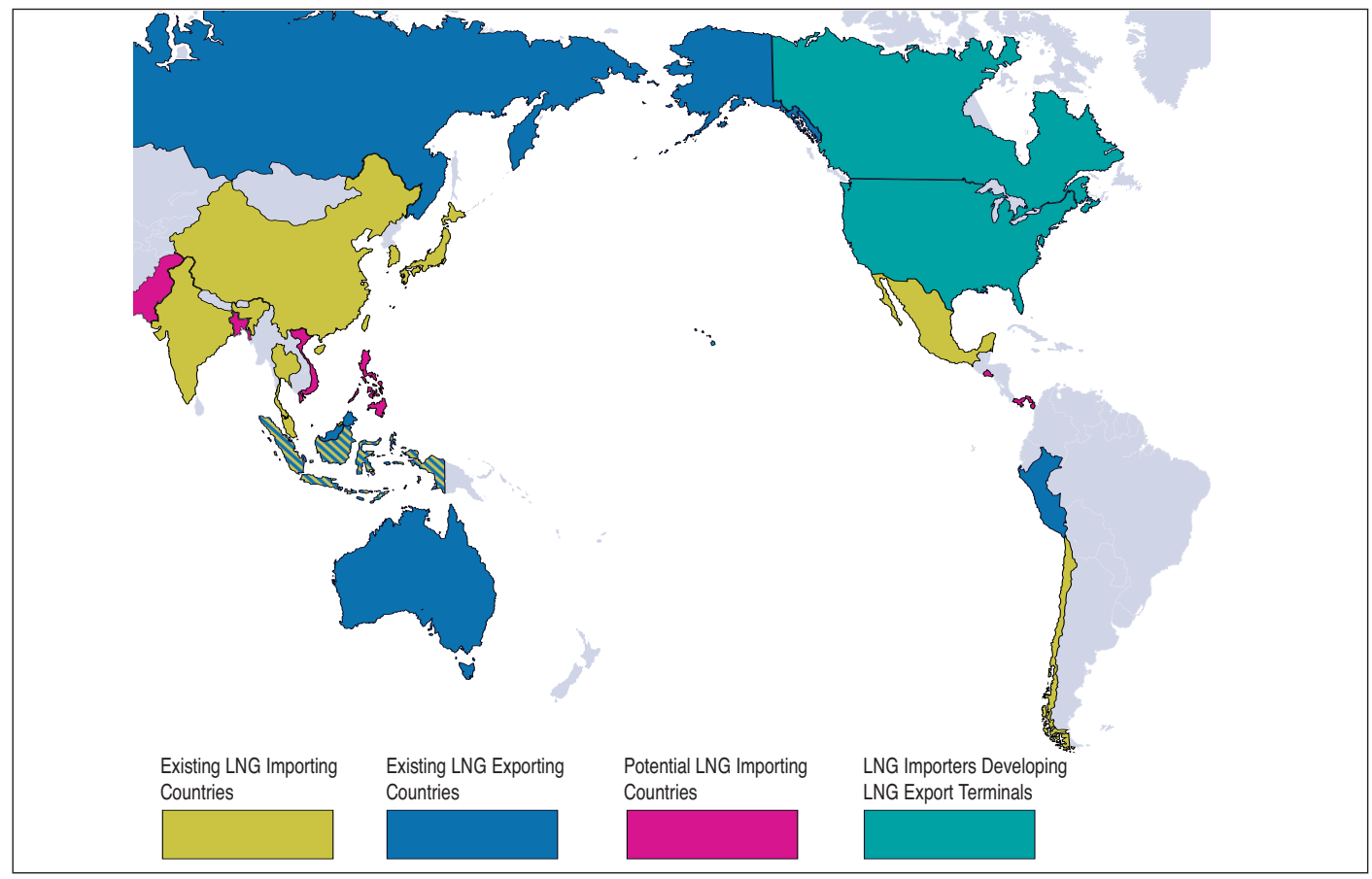

Source: See Appendix E amd F.

As noted by the International Energy Agency (IEA), the Asia-Pacific natural gas market is fragmented, and not highly interconnected by pipelines, as is the case in Europe and North America. ${ }^{30}$ It can be argued that the region has three separate markets. The first is the developed markets of Japan, South Korea and Taiwan, considered to be traditional LNG buyers, with limited future growth. The second is the emerging large consumers of India and China, expected to have considerable future natural gas demand. The third market is in Southeast Asia, with several large natural gas and LNG producers, in addition to limited pipeline interconnections.

30 IEA, Developing a Natural Gas Trading Hub in Asia (Paris: 2013). 
The world demand for natural gas delivered as LNG increased 275 per cent between 1993 and 2012, equivalent to a compound annual average growth rate of 7.21 per cent. ${ }^{31}$ In the AsiaPacific region, recent strong growth in LNG imports is concentrated in China and India, though year-over-year growth in Asia excluding China has averaged 12.9 per cent between 2009 and $2012 .{ }^{32}$

Growth in regasification capacity is a convenient proxy for the demand growth in the AsiaPacific basin since 2008 as LNG buyers expanded capacity in anticipation of increased imports. Table 2.1 and Figure 2.9 show capacity utilization (imports divided by capacity) for the major Asian LNG importers. ${ }^{33}$

TABLE 2.1: MAJOR LNG IMPORTERS' REGASIFICATION CAPACITY AND UTILIZATION (BCM)

\begin{tabular}{|l|l|r|r|r|r|r|}
\hline & & $\mathbf{2 0 0 8}$ & $\mathbf{2 0 0 9}$ & $\mathbf{2 0 1 0}$ & $\mathbf{2 0 1 1}$ & $\mathbf{2 0 1 2}$ \\
\hline \multirow{3}{*}{ China } & Capacity & 9.1 & 10.7 & 13.4 & 26.8 & 31.8 \\
& Utilization & $50.55 \%$ & $71.31 \%$ & $85.82 \%$ & $61.90 \%$ & $60.09 \%$ \\
\multirow{3}{*}{ Japan } & Capacity & 11 & 16.8 & 16.8 & 16.8 & 18.4 \\
& Utilization & $101.45 \%$ & $74.46 \%$ & $73.57 \%$ & $85.00 \%$ & $91.85 \%$ \\
South Korea & Capacity & 252.6 & 263.4 & 264.2 & 252.1 & 273.8 \\
& Utilization & $37.76 \%$ & $35.27 \%$ & $37.39 \%$ & $46.20 \%$ & $44.42 \%$ \\
Taiwan & Capacity & 107.6 & 110 & 110 & 124.6 & 128 \\
& Utilization & $34.59 \%$ & $30.65 \%$ & $39.84 \%$ & $37.50 \%$ & $37.34 \%$ \\
& Capacity & 33.8 & 33.8 & 33.8 & 14.2 & 15.7 \\
\hline
\end{tabular}

Source: IEA, Natural Gas Information 2009-2013, 93-97.

Four of the major importers in the Asia-Pacific region increased regasification capacity between 2008 and 2012; China by almost 250 per cent. Taiwan is the sole country with a capacity decrease. Capacity utilization increased in all five major importers, reflecting increased demand for natural gas. It is noteworthy that China's utilization rate is only 10 percentage points lower in 2012 than in 2009, despite almost it tripling its regasification capacity. This is graphically demonstrated in Figure 2.9 below in the context of year over year growth in percentage by country (not total volume).

\footnotetext{
31 Authors' calculations, based on: IEA, "World - Natural Gas imports by origin," IEA Natural Gas Information Statistics (database), 2013, doi: 10.1787/data-00555-en.

32 ibid.

33 In some cases utilization is over 100 per cent. This can occur if imported natural gas is stored, by operators increasing pressure in storage tanks, or if functional capacity is greater than designed capacity (similar to red-lining a car engine). However, both GIIGNL and IEA report a sudden decrease in Taiwanese regasification capacity, with a loss of 53 per cent in 2012 or 57 per cent in 2011, respectively. In that time period, it does not appear that any regasification facility in Taiwan closed, went offline, or was damaged. No note addressing this decrease was available in each respective report. The IEA did not report a change in the number of vaporization units at any of Taiwan's facilities during this time. The most likely explanation of this change was the correction of a reporting or statistical error.
} 
FIGURE 2.9: MAJOR LNG IMPORTERS' REGASIFICATION CAPACITY UTILIZATION

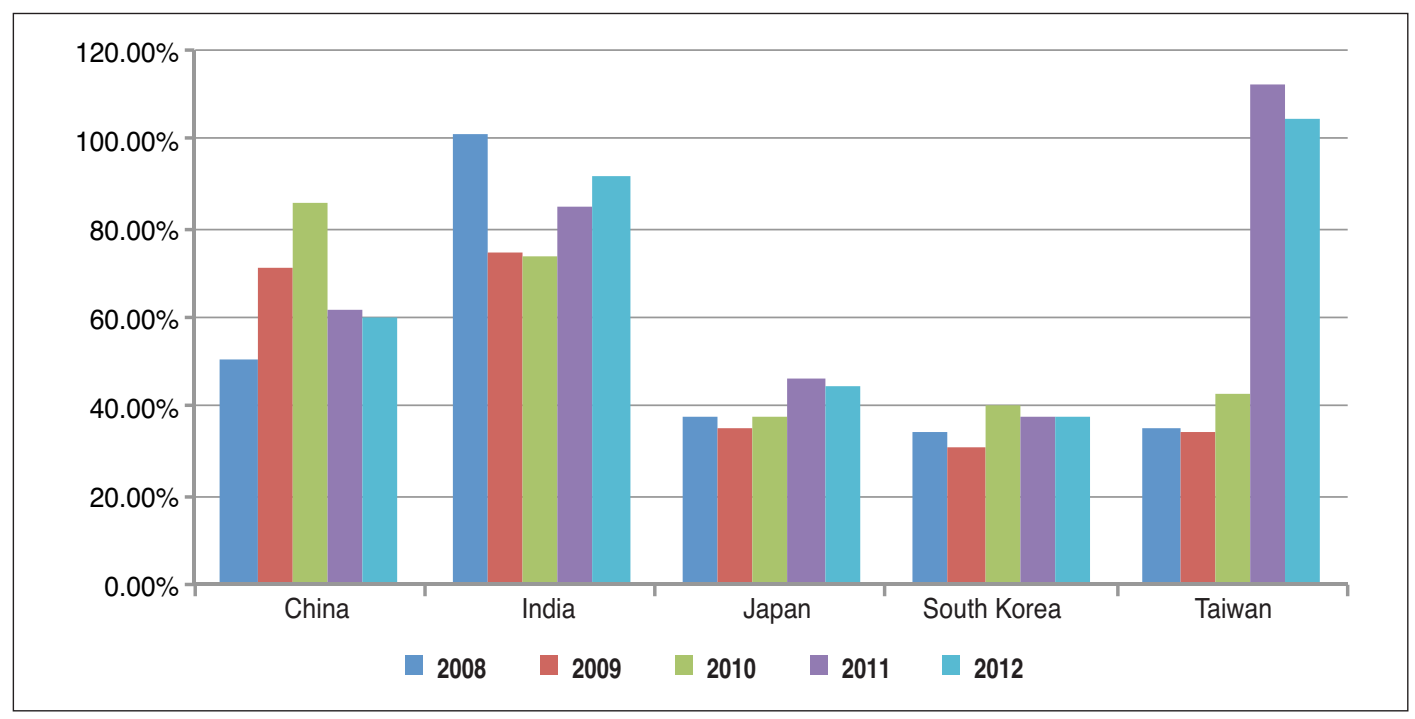

Source: IEA, Natural Gas Information 2009-2013, 93-97.

As seen in Table 2.2, power generation dominates the demand for natural gas, while industrial shares are relatively low, with the exception of Indonesia, which has a large petro-chemical sector. In countries such as Japan, South Korea and Taiwan, the source most relied upon is LNG.

TABLE 2.2: ASIA-PACIFIC NATURAL GAS DEMAND (2011)

\begin{tabular}{|l|c|c|c|c|c|c|}
\hline & \multirow{2}{*}{$\begin{array}{c}\text { Share of Gas } \\
\text { in Energy Mix }\end{array}$} & $\begin{array}{c}\text { Per cent of Total } \\
\text { Gas Supplied } \\
\text { as LNG }\end{array}$ & \multicolumn{4}{|c|}{ Gas Demand By Sector* } \\
\cline { 4 - 7 } & & $97 \%$ & $68 \%$ & $8 \%$ & $0 \%$ & $26 \%$ \\
\hline Japan & $21 \%$ & $99 \%$ & $47 \%$ & $18 \%$ & $3 \%$ & $32 \%$ \\
South Korea & $16 \%$ & $98 \%$ & $78 \%$ & $8 \%$ & $0 \%$ & $9 \%$ \\
Taiwan & $12 \%$ & $12 \%$ & $24 \%$ & $17 \%$ & $8 \%$ & $27 \%$ \\
China & $6 \%$ & $27 \%$ & $41 \%$ & $18 \%$ & $5 \%$ & $0 \%$ \\
India & $7 \%$ & $2 \%$ & $68 \%$ & $10 \%$ & $6 \%$ & $0 \%$ \\
Thailand & $29 \%$ & $0 \%$ & $25 \%$ & $30 \%$ & $0 \%$ & $0 \%$ \\
Indonesia & $19 \%$ & & & & & \\
\end{tabular}

*Note: Demand shares do not add to 100 per cent because of other demand sources.

Source: PFC Energy, Global LNG Demand and Supply Study (May 2013).

Much of the 2012 LNG sourced to Japan and other Asia-Pacific nations (approximately 40 per cent) came from within the Pacific Basin - primarily from Australia, Malaysia and Indonesia. ${ }^{34}$ The Middle East (Qatar, Oman, the United Arab Emirates and Yemen) provided another 40 per cent, with the balance secured from other exporting countries. However, supply sources for individual countries vary widely; for example, India sourced 80 per cent of its LNG from Qatar in 2012, with the remainder from other Middle Eastern countries. ${ }^{35}$ At the other extreme, China imported 55 per cent from in-region and 25 per cent from Qatar in 2012; Japan imported 43 per cent from in-region and 11 per cent from Qatar. The 2012 supply-demand balance for Asia-Pacific is reported in Table 2.3.

\footnotetext{
34 BP, BP Statistical Review (2014).

35 IEA, "World - Natural Gas imports."
} 
TABLE 2.3: 2012 ASIA-PACIFIC NATURAL GAS SUPPLY AND DEMAND BY COUNTRY (BCM)

\begin{tabular}{|l|c|c|c|c|c|}
\hline Country & $\begin{array}{c}\text { Proved } \\
\text { Reserves }\end{array}$ & $\begin{array}{c}\text { Domestic } \\
\text { Production }\end{array}$ & $\begin{array}{c}\text { Domestic } \\
\text { Consumption }\end{array}$ & $\begin{array}{c}\text { LNG } \\
\text { Imports }\end{array}$ & $\begin{array}{c}\text { LNG } \\
\text { Exports }\end{array}$ \\
\hline China* & 3,100 & 107.2 & 146.6 & 20 & \\
India & 1,300 & 40.2 & 54.6 & 20.5 & 118.8 \\
Japan & & & 8.3 & & \\
Singapore & & & 50 & 49.7 & \\
South Korea & 300 & 41.4 & 16.3 & 16.9 & \\
Taiwan & 3,800 & 49 & 25.4 & & \\
Thailand & 300 & 12.6 & & & \\
Australia & 2,900 & 71.1 & 35.8 & & \\
Brunei & 1,300 & 65.2 & 33.3 & & \\
Indonesia & 200 & 12.7 & & & \\
Malaysia & 600 & 41.5 & 41.5 & & \\
Myanmar & 200 & 21.8 & 21.8 & & \\
Pakistan & & & & \\
Bangladesh & & & & \\
\hline
\end{tabular}

* China includes the Hong Kong Special Administration Region, but not Singapore. All figures exclude pipeline imports.

Japan imports the most LNG in the Asia-Pacific region and is also the world's largest importer, sourcing between 87 and 90 MMT (118 to $122 \mathrm{BCM}$ ) in 2012. ${ }^{36}$ This reflects an increase in LNG demand (around 16.8 MMT, depending on the source) as a result of the increased demand for gas-fired power generation after the Fukushima nuclear incident led to policy shifting away from nuclear power. Future demand for LNG in Japan is highly contingent upon the government's policies with respect to nuclear power. Japan's LNG demand is not expected to grow much beyond 89 MMTPA, since this reflects a "high-water mark" for LNG demand, with all nuclear facilities shut down. Further substitution away from nuclear to coal- or natural gas-based electricity to support demand growth would only have a marginal effect on LNG demand, as new natural gas plants are expected to be more efficient than Japan's existing natural gas power facilities.

South Korea's LNG demand is expected to exceed 40 MMT by 2020, while demand in Taiwan is expected to pass $15 \mathrm{MMT} .^{37}$ In non-OECD Asia, the economies of China and India are expected to command the most interest in natural gas and LNG, according to the EIA. ${ }^{38}$ China is expected to increase LNG demand from 15 MMT in 2012 to 50 MMT in $2020 .{ }^{39}$ Existing contracts will provide India with $18.55 \mathrm{MMT}$ in $2020,{ }^{40}$ but PFC Energy suggests that actual imports could be much higher, at $30 \mathrm{MMT}^{41}$

\footnotetext{
${ }^{36}$ Note that the reported imports vary by source; IEA data report 90 MMT in 2012, while GIIGNL and BP report 88 MMT, and IGU reports 87 MMT.

37 PFC Energy, "Global LNG Supply and Demand Study," 2013.

38 EIA, International Energy Outlook 2013 (Washington, D.C.; U.S. Department of Energy, 2013). Under the reference case, non-OECD Asia is the only regional grouping that changes from a natural gas exporter to a natural gas importer.

39 PFC Energy, "Global LNG."

40 Bloomberg POTN (Poten \& Partners) LNG Contract database.

41 PFC Energy, "Global LNG."
} 
Demand by country and sources of supply for the Asia-Pacific region are described in greater detail in Section 4.1, but the extent to which new natural gas demand will be supplied by LNG depends heavily on the extent to which inter-regional pipelines are developed. The current lack of pipeline interconnection suggests new demand will be supplied via LNG imports, but this may change. In particular, China's choices will be particularly influential.

\section{OVERVIEW OF GLOBAL LNG MARKETS}

The supply system for natural gas is a function of a complex set of interdependent systems and installed capacity ranging from wells, gathering and processing, and transport to market via pipeline or liquefaction and regasification. On the demand side this includes power generation, heating for industrial buildings, plastics, chemical and fertilizer production and ultimately town gas for distributed customers. Increasing demand is emerging for transportation systems. Global demand for natural gas has been increasing as a function of increased energy demand in developing countries as well as new environmental policies designed to phase out coal-fired electricity generation, among other things.

\subsection{Commercial Structure of LNG Markets}

LNG markets operate as a subcategory of general natural gas development and delivery. In the tidewater delivery of natural gas, when terrestrial pipelines cannot be used, LNG ships carry out the transportation and handling function, linking export tidewater ports to tidewater importing and regasification facilities for importing nations. LNG markets depend on a supply system that is large and typically diverse in order to assure adequate sourcing and quality. These supplies are guaranteed in various iterations of delivery contracts including take or pay, firm delivery and (less often) spot-market purchases. Because of the nature of the delivery stream serving key clients such as utilities for power generation, supply contracts are subject to penalties for failure to deliver or interruptions of service.

The market is built on access to shipping and special-purpose refrigeration ships capable of holding chilled gas from exporting to importing nations. These purpose-built fleets are unique in design and structure and travel predictable and uniform routes from exporter to importer on regular schedules. Pricing for LNG delivered gas typically includes all costs of operation of the ships, including net generation demands from on-board gas to power the vessel. As discussed above, LNG markets are a special sub-category of natural gas markets. The simplified process that natural gas goes through to become LNG is illustrated in Figure 3.1. 
FIGURE 3.1: PHYSICAL FLOW OF LNG MARKETS

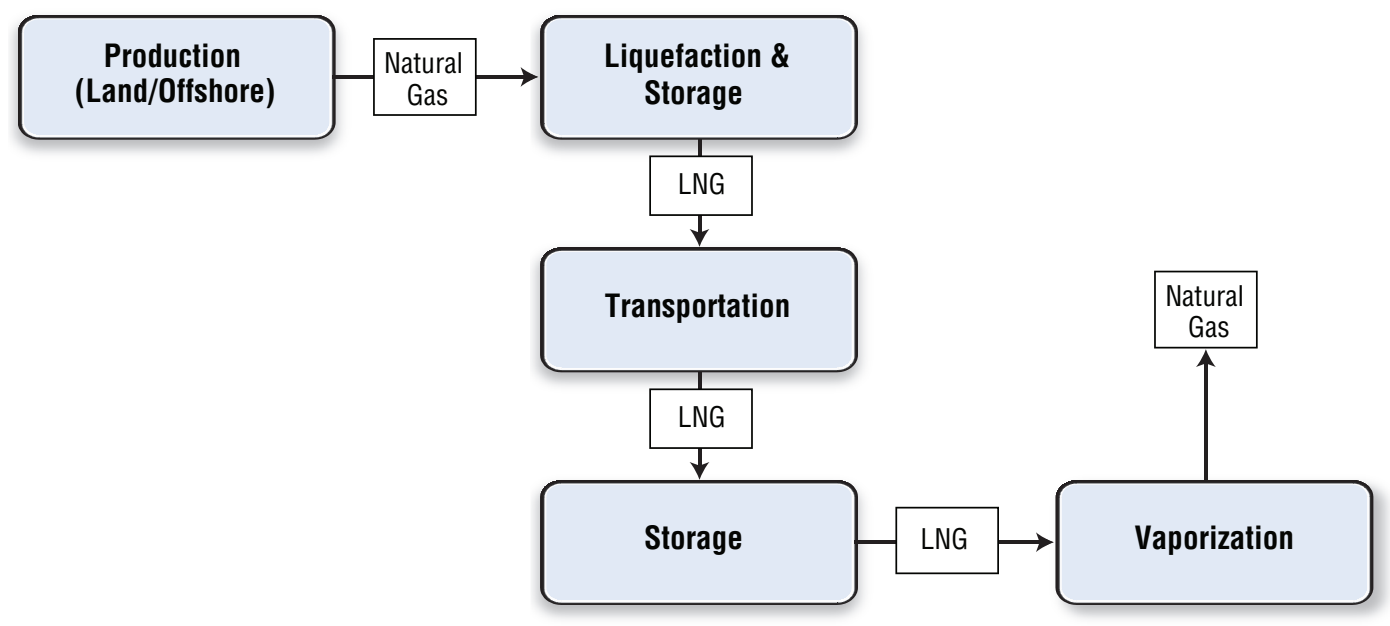

Source: Based on Philip R. Weems and Monica Hwang, "Overview of issues common to structuring, negotiating an documenting LNG Projects," Journal of World Energy Law and Business 6, 4 (2013).

\section{COMPONENTS OF NATURAL GAS MARKETS}

Gas Producers - These companies perform exploration and development activities, from drilling and producing wells to field gas gathering and separation of produced gas, hydrocarbon liquids and water. They range from large, integrated producers (majors) to small operators with limited facilities.

Gas Processing - Processing companies gather gas from gas producers, separate natural gas and hydrocarbon liquids, and remove additional impurities in the gas to meet transmission-pipeline quality specifications.

Transmission Pipelines - Pipeline capacity is necessary for consolidating, transporting, and in-line temporary storage of delivered gas to appropriate markets.

Natural Gas Storage - Natural gas storage operations act as buffers in managing the delivery of gas supplies to consumers (due to daily and seasonal demand fluctuations, facility upsets, etc.).

Marketing - Most of the gas in North America is handled by natural gas marketers in the form of managing physical delivery and arranging financial compensation and accounting. The volume of nonphysical natural gas that passes through the hands of marketers is very large, and can be much greater than the actual physical volume consumed, when both domestic and export volumes are taken into account.

Local Distribution Companies - Local distribution from regional or district pipelines is accomplished using these companies that maintain delivery capacity to final users.
This report deals with LNG as a marketchanging phenomenon; it is important to note that LNG is a transportation and fuel-phase system. In reality, the demand for LNG, and the nature of LNG markets, is rooted in the demand for natural gas as a fuel or feedstock. The heart of LNG markets is based in a traditional natural gas market, replacing pipeline transmission as the primary transportation mechanism between markets.

According to Weems and Hwang, LNG projects were historically developed as an integrated supply chain with dedicated facilities and associated activities (gas production, transmission, liquefaction and storage in the exporting country; marine transport; and regasification and distribution in the importing country). ${ }^{42}$ They note that "in a fully integrated LNG chain, all parties are effectively exposed to all risks in the LNG chain since failure in any part of the chain affects all other parts." However, commercial structures vary across projects, and there is no worldwide standard for determining

42 Philip R. Weems and Monica Hwang, "Overview of issues common to structuring, negotiating an documenting LNG Projects," Journal of World Energy Law and Business 6, 4 (2013). 
project structure. Participation, financing, gas supply, revenue sharing, transfer pricing and the contracts determining these components all must satisfy the requirements of the project developers, resulting in commericial structures unique to each project. However, there are types of structures that have evolved such that the majority of projects can be classified as: project company, tolling company and unincorporated joint venture (JV).

Under the project-company structure, the project sponsors are shareholders in a company that owns the LNG export plant. The project company purchases gas from upsteam producers, liquefies the gas, sells the LNG to third parties, and receives revenue from the LNG sale. The revenues are distributed to the participants as dividends. The project-company structure has been used in the countries of Trinidad and Tobago, Australia, Malaysia, Qatar, and Russia, among others. Figure 3.2 illustrates the typical commericial structure of a project-company framework..$^{43}$ An interesting feature of the project-company framework is that shareholders can participate in some parts of the LNG supply chain but not others. ${ }^{44}$

FIGURE 3.2: PROJECT COMPANY COMMERCIAL STRUCTURE

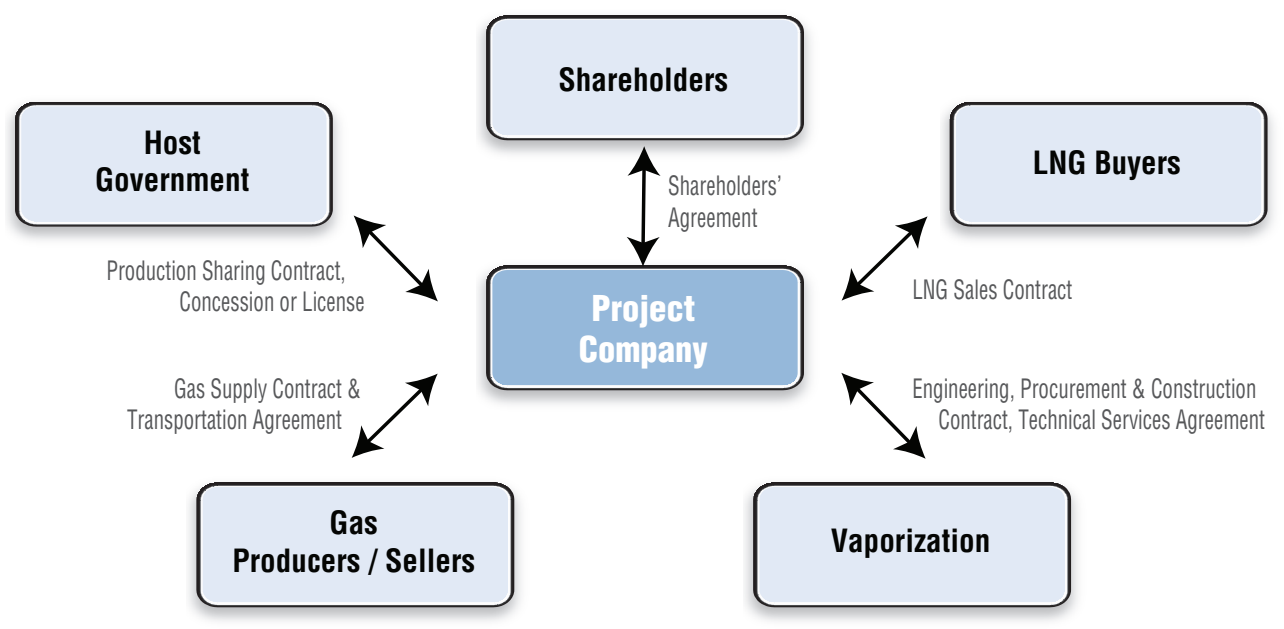

Source: Philip R. Weems and Monica Hwang, "Overview of issues common to structuring, negotiating an documenting LNG Projects," Journal of World Energy Law and Business 6, 4 (2013).

Under the tolling-company structure, the tolling company provides liquefaction services to the gas owners for a fee. In the Indonesian version of a tolling-company structure, the tolling facility is owned and operated by the government of Indonesia on a non-profit basis, with all revenues passed through to the government and upstream gas producers. Many of the U.S. LNG export projects (e.g., Freeport LNG and Cameron LNG) use a tolling-company structure, where the tolling company provides liquefaction services for a negotiated fee. Figure 3.3 illustrates the typical commericial structure of a tolling-company framework. ${ }^{45}$

\footnotetext{
43 Weems and Hwang, "Overview of issues."

44 Further details are available in Weems and Hwang, "Overview of issues."

45 Weems and Hwang, "Overview of issues."
} 
FIGURE 3.3: TOLLING COMPANY COMMERCIAL STRUCTURE

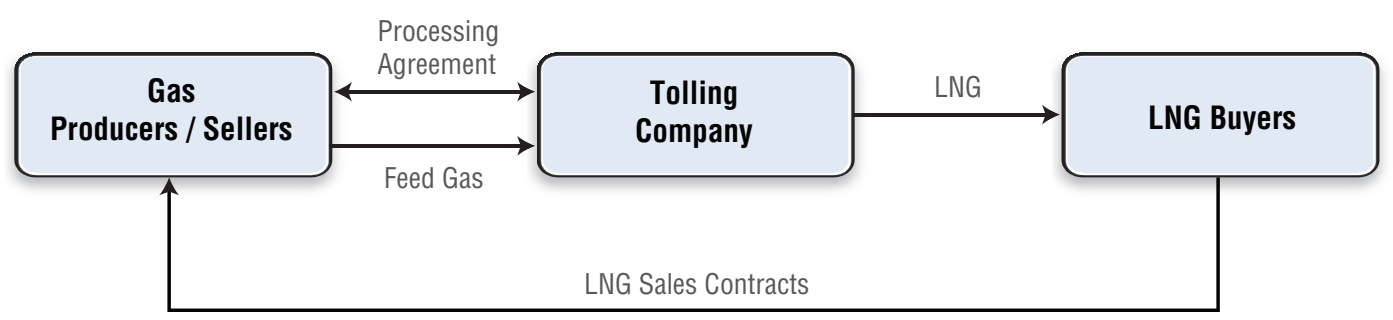

Source: Philip R. Weems and Monica Hwang, "Overview of issues common to structuring, negotiating an documenting LNG Projects," Journal of World Energy Law and Business 6, 4 (2013).

The unincorporated-JV approach to LNG structure is common for large upstream or integrated oil and gas companies looking for alternative markets, similar to the environment in Canada. One notable example of the unincorporated-JV structure is the Northwest Shelf Project in Australia. Each participant in this project owns one-sixth of the LNG plant, supplies one-sixth of the feed gas, and receives one-sixth of the revenues, although the participation shares could have been different, as they are in most unincorporated-JV projects. ${ }^{46}$ The governing document for the management and operation of an unincorporated-JV is a joint-venture project agreement. Figure 3.4 illustrates a simplified version of an unincorporated-JV framework.

FIGURE 3.4: SIMPLE UNINCORPORATED JOINT VENTURE COMMERCIAL STRUCTURE

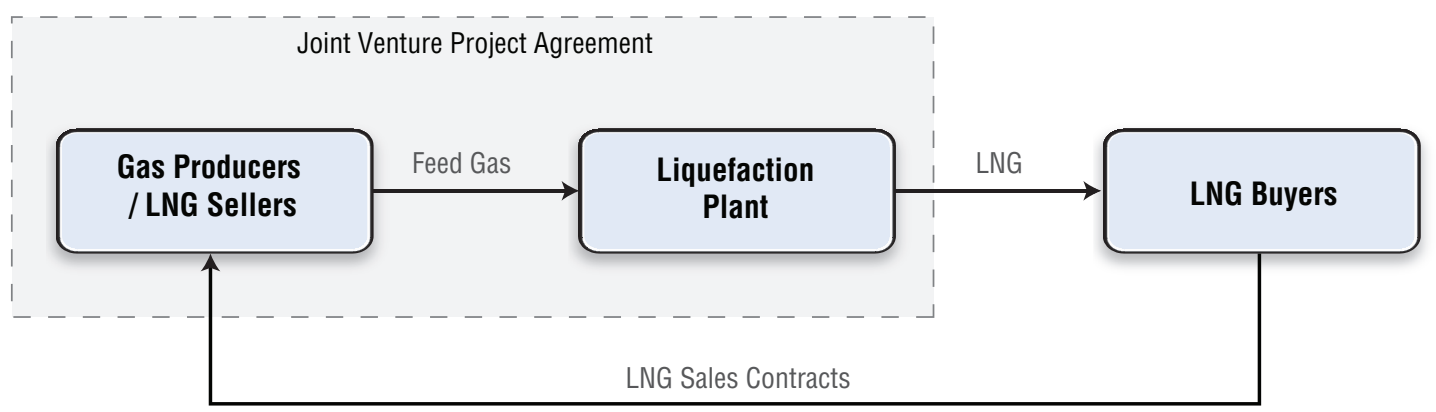

Source: Stillwater Associates.

It is anticipated that most of the Canadian LNG export projects will be structured as unincorporated-JVs. A more detailed framework for a Canadian joint venture is likely to have the physical and commercial components illustrated in Figure 3.5.

46 Weems and Hwang, "Overview of issues," 283. 


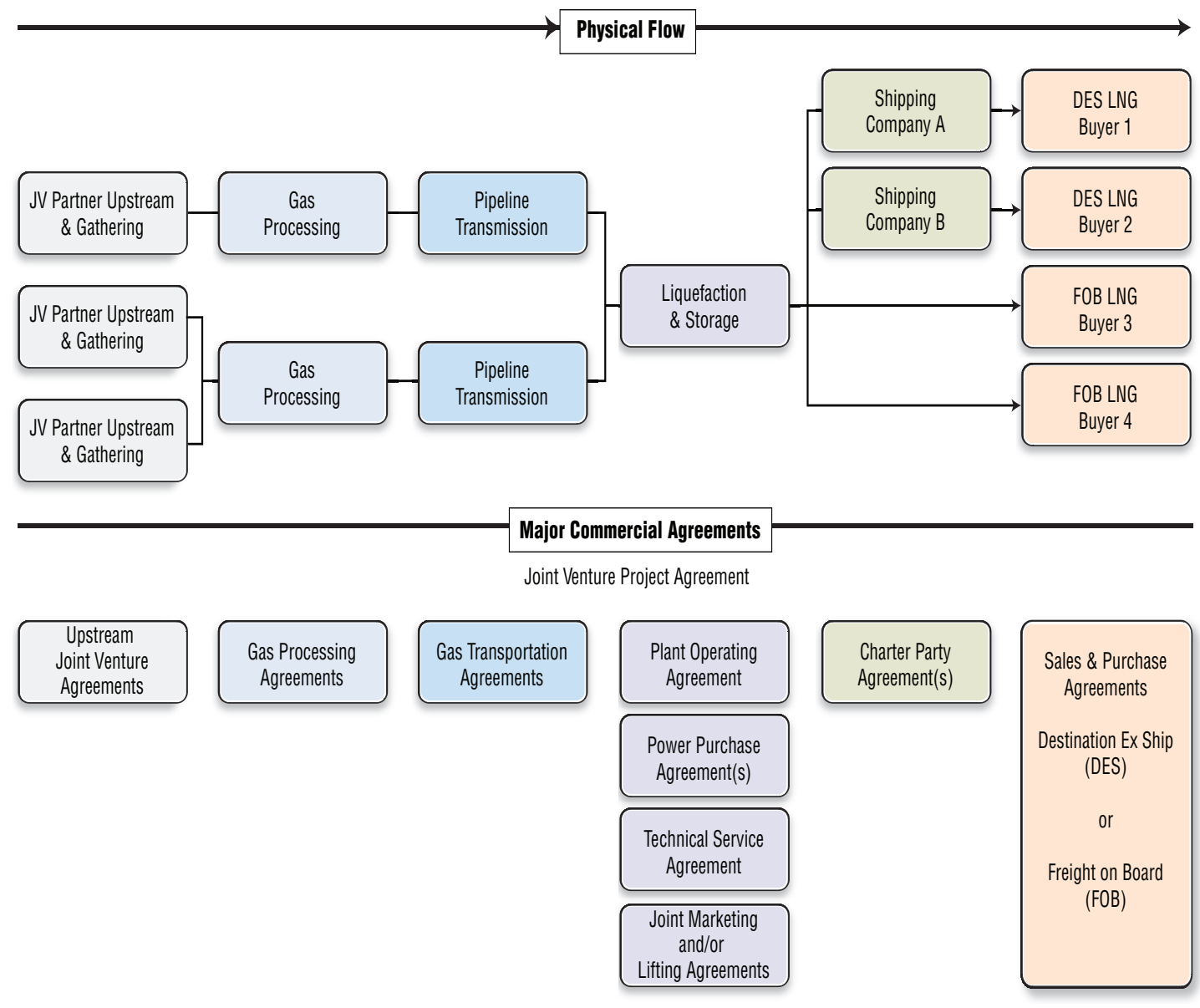

Source: Stillwater Associates.

The financing of capital-intensive liquefaction facilities is underpinned by long-term (15-30 year) LNG contracts or sales-and-purchase agreements (SPAs). Typically, liquefaction projects require that long-term sale-and-purchase agreements representing at least 80 per cent of plant capacity be executed before a final investment decision (FID) is taken and a notice to proceed (NTP) is issued to start construction. The project sponsors, and their financiers, usually require a portfolio of buyers to mitigate performance risk. The balance of plant capacity is available for incremental sales to long-term customers, for short-term (zero to four years) and mediumterm (five to 15 years) sales, and spot sales (individual cargoes). Spot cargoes are traded in individually negotiated transactions, often based on pre-negotiated master sales agreements put in place in advance, between sellers and buyers with longstanding relationships.

\subsection{Recent Activity in LNG markets}

Finance and financing arrangements appear to be the major driver in $\operatorname{spot}^{47}$ and short-term trades in the LNG market. Following a long period of stable shipping arrangements, this market has seen an increase in volatility according to the International Gas Union (IGU), an

\footnotetext{
47 Spot and short term are contracts that trade at current delivered price or less than "long-term" contracts that are greater than five years in the future. They may also include those contracts serviced in addition to existing take-orpay arrangements per shipment.
} 
industry association. ${ }^{48}$ The IGU cites a considerable increase in divertible options, and more flexible contracts have allowed trading companies to arbitrage shipments, greatly enhancing the volumes and value of the market overall.

LNG has been delivered under long-term arrangements between buyers and sellers and traded on a spot and short-term basis in the Asian markets at the end of a contract delivery. Prior to 2000 , spot and short-term sales comprised less than five per cent of total deliveries in terms of volume..$^{49}$ By 2005 this had changed, growing to nearly 20 per cent by 2010 , and 25 per cent in $2012 .^{50}$ The increase in short-term and spot sales is the result of "tail-end" sales from projects that have passed their original long-term contract periods; the increased flexibility of the industry resulting from the growing number of suppliers and buyers; the expanding role of portfolio suppliers; and the diversion of deliveries from the U.S. to Asia due to the shale gas revolution in the U.S. and the huge spike in LNG demand in post-Fukushima Japan. The inability of buyers in Japan and South Korea to commit to long-term LNG purchases due to policy uncertainties, and negotiating standoffs between suppliers and buyers over prices, has continued to underpin demand for spot and short-term purchases in the Asia-Pacific region.

In the current market, Asian buyers made up 72 per cent of spot LNG in 2012. ${ }^{51}$ Of this, Japan, South Korea, and India combined accounted for 61 per cent. ${ }^{52}$ Before 2000 , spot and shortterm sales were estimated to be less than five per cent of total volume traded, expanding to as high as 73.5 MMT by $2012-31$ per cent of global sales (driven in large measure by Japan replacing lost nuclear generating-capacity). ${ }^{53}$

In 2012, LNG shipments fell by 1.9 per cent from 240.4 MMT in 2011 to $235.6 \mathrm{MMT}^{54}{ }^{5} \mathrm{Japan}$ and South Korea were the most significant importers, in part due to the Fukushima accident, capturing 52.8 per cent of the world market, up three per cent from 2011. World spot and shortterm LNG sales were 73.5 MMT in 2012, or 31 per cent of total volumes, an increase from 65.1 MMT in 2011. ${ }^{55}$ The International Gas Union states that almost half of spot export volumes were supplied by Qatar and Nigeria. ${ }^{56}$ Much of this demand reflects the structure of regional gas systems that are limited by national borders, and a lack of domestic production in Japan, South Korea and Taiwan, forcing a greater dependency on spot-market supplies when demand increases beyond contracted volumes.

\footnotetext{
48 International Gas Union, World LNG Report (2013), 7.

49 ibid., 13.

50 International Group of LNG Importers (GIIGNL), The LNG Industry in 2012 (Paris: GIIGNL, 2012), http://www.giignl.org/system/files/publication/giignl_the_lng_industry_2012.pdf. The International Gas Union reports that spot trades accounted for 31 per cent of total volume in 2012. (International Gas Union, World LNG)

51 International Gas Union, World LNG.

52 ibid., 7.

53 ibid., 13.

54 Authors' calculations, based on: IEA, "World - Natural Gas imports."

55 International Gas Union, World $L N G$.

56 ibid.
} 
The LNG market is highly dependent on adequate shipping capacity. According to the International Gas Union, "at the end of 2012, the global LNG fleet consisted of 362 vessels of all types, with a combined capacity of $54 \mathrm{BCM}$... This is more than one and a half times the size of the fleet at the end of 2006." ${ }^{, 57}$ Additional detail on LNG shipping is available in Section 3.5.2, below. In recent years, seven countries re-exported LNG imported from other countries. In 2012, 3.5 MMT of LNG was re-exported, primarily from Europe, where natural gas demand was weak, to South America and the Asia-Pacific, where demand was stronger and prices were higher. ${ }^{58}$ The number of cargoes re-loaded rose from 44 in 2011 to 75 in 2012..$^{59}$

\subsection{North American Natural Gas and LNG Prices}

Natural gas prices in North America ${ }^{60}$ have been volatile, especially when viewed over an extended period (see Figure 3.6). Over the short term, natural gas prices have a normal seasonal volatility. ${ }^{6 l}$ However, over the longer term, the natural gas prices also reflect the supply and demand balance of North American gas production to the demand for natural gas supply that is served by the gas pipeline infrastructure.

Figure 3.6 shows monthly prices for AECO and Henry Hub since 1995. The underlying price trends were upward until late 2008 when the price declined sharply, driven by the advancements that made shale gas reserves available. The Henry Hub price reached a low monthly average of \$1.93/GJ (\$2.04 per million BTU) in May 2012 but has since drifted back up to the four-dollar range.

Linked by a pipeline infrastructure system, Canadian gas prices are closely tied to U.S. prices. For instance, the price of Canadian gas at AECO closely tracks that of Henry Hub, but reflects the slight discount applied for distance, as seen in Figure 3.6. The close linkage of the U.S. and Canadian markets via the well-developed pipeline infrastructure ties the price destiny of

Canadian gas to U.S. gas.

57 ibid., 7.

58 ibid.

59 GIIGNL, The LNG Industry in 2012.

60 Although natural gas markets include flows from Canada, the United States and Mexico, the primary pricing hub for North America is in the United States at Henry Hub.

61 Space heating in the winter generally increases natural gas consumption. Typically this seasonal demand exceeds pipeline delivery capacity, creating a need for local or regional storage to balance supplies, typically filling during the summer months when production exceeds demand. However, the seasonal nature of demand for natural gas is changing throughout North America. This suggests that the balancing roles for storage are changing and new outlets for excess natural gas supplies will be needed - whether from new domestic demand or in the form of LNG exports. 
FIGURE 3.6: AECO AND HENRY HUB MONTHLY PRICES

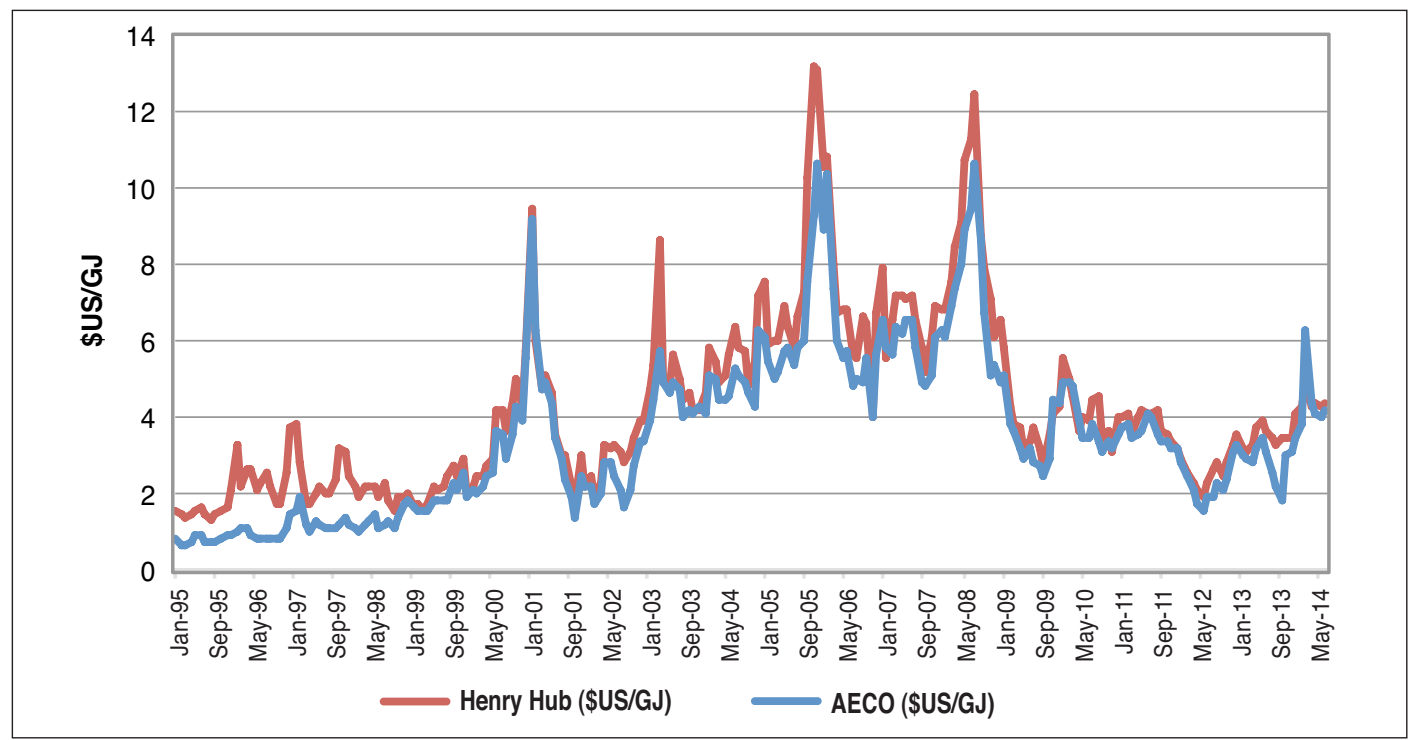

Note: AECO price is 30-day spot, Henry Hub price is NYMEX close. Conversion of AECO price from Canadian to U.S. dollars used Sproule exchange rate. Original prices in \$/MMBTU; conversion factor used is 0.947817.

Source: Sproule website, "Forecasts," http://www.sproule.com/forecasts

The recent developments that have opened reserves of shale gas in the U.S. and Canada (but not yet in Mexico) have led many to project that gas prices will remain at current levels (reflecting the cost of development) for the foreseeable future. ${ }^{62}$

In contrast to North America, the Asia-Pacific region lacks the gas resources and regional gaspipeline networks to lace the region into a single market. Instead, natural gas and oil must be imported and are, in effect, competing fuels. Thus, oil has served as the marker price for gas in Asia-Pacific.

LNG pricing in the Asian market is less influenced by short- and mid-term supply and demand for gas because it has long been underpinned by long-term supply contracts with formula pricing. Japan has historically defined the market since it has been the major LNG customer. As demand developed in other Asian countries, the Japanese pricing model was basically followed. The primary index used is the JCC price, which is the average price of customscleared crude oil imports into Japan (formerly the average of the top 20 crude oils by volume) as reported in customs statistics - nicknamed the "Japanese crude cocktail."

JCC is a commonly used index in long-term LNG contracts in Japan, South Korea and Taiwan. The data to calculate JCC are published by the Japanese government every month. These are the raw- and crude-oil import prices in yen per kilolitre, the daily dollar yen exchange rate, and the total Japanese imports of all commodities for the month.

The fact that Asian natural gas prices have been high relative to other markets is a function of the effect of limited gas supply on gas competition due to a lack of inter-country pipeline links and existing 20-year rolling contracts that are based on JCC. Recently, the loss of nuclear baseload capacity in Japan has put short-term, upward pressure on LNG prices.

62 The EIA predicts natural gas prices will remain low, at \$4.57/GJ (\$4.33/MMBTU) in 2015. See: EIA website, "Short Term Energy Outlook - Natural Gas," http://www.eia.gov/forecasts/steo/report/natgas.cfm. 
There is currently a great deal of attention being paid to alternative pricing mechanisms to eliminate the linkage to oil markets and to price deliveries closer to world market prices. One of these alternative pricing mechanisms arises from the development of American LNG export terminals. The pricing model in the U.S. is Henry Hub-cost-plus, where pipeline gas is tolled through the liquefaction plant and transported to its destination. Thus, the price to the customer is the Henry Hub price, plus the fee to toll through the liquefaction plant, plus the cost of transport. In this model, the developer of the liquefaction plant may be completely independent of the gas producer, pipeline transporter, LNG transporter, LNG marketer and LNG customer.

\subsection{World LNG Demand}

Demand for LNG is derived solely from the demand for natural gas where there is a lack of adequate domestic production or terrestrial pipeline delivery capacity. In 2012, global natural gas consumption (demand) was about 3,300 BCM, while global demand (total imports) for LNG was about 240 million tonnes (MMT), equivalent to about $330 \mathrm{BCM}$ of natural gas. ${ }^{63}$ Today the global demand for LNG, natural gas in liquid form, represents only 10 per cent of the total global demand for natural gas.

The EIA's 2013 International Energy Outlook ${ }^{64}$ projects that world energy consumption will grow by 56 per cent between 2010 and 2040. Total world energy use in non-OECD countries is expected to increase by 90 per cent; in OECD countries, the expected increase is 17 per cent. The EIA expects total natural gas trades, both by pipeline and by shipment in the form of LNG, to increase steadily over the next decade. In North Africa and Southeast Asia, domestic natural gas consumption is forecast to have higher value than exports, leading to the underutilization of liquefaction facilities in those countries during this period.

As mentioned previously, world LNG demand (proxied by trade volume) grew by 275 per cent between 1993 and 2012, equivalent to a compound annual rate of 7.2 per cent. Figure 3.7 plots the world's natural gas trade between 1993 and 2012. While pipeline trade dominates, the LNG share of the world's natural gas trade has increased from 18 per cent in 1993 to 31 per cent in 2012. World demand for natural gas is forecast to grow on average at 1.6 per cent per year to 2035 , and inter-regional gas trade by two per cent per year, with LNG trade projected to account for 60 per cent of this increase in trade, showing its growing importance as an alternative to pipeline supplies. ${ }^{65}$

63 BP, BP Statistical Review (2013).

64 EIA, International Energy Outlook 2013.

65 IEA, World Energy Outlook 2013 (London: IEA, 2013), http://www.worldenergyoutlook.org/publications/weo-2013/. 
FIGURE 3.7: WORLD NATURAL GAS TRADE 1993 - 2012 (BCM)

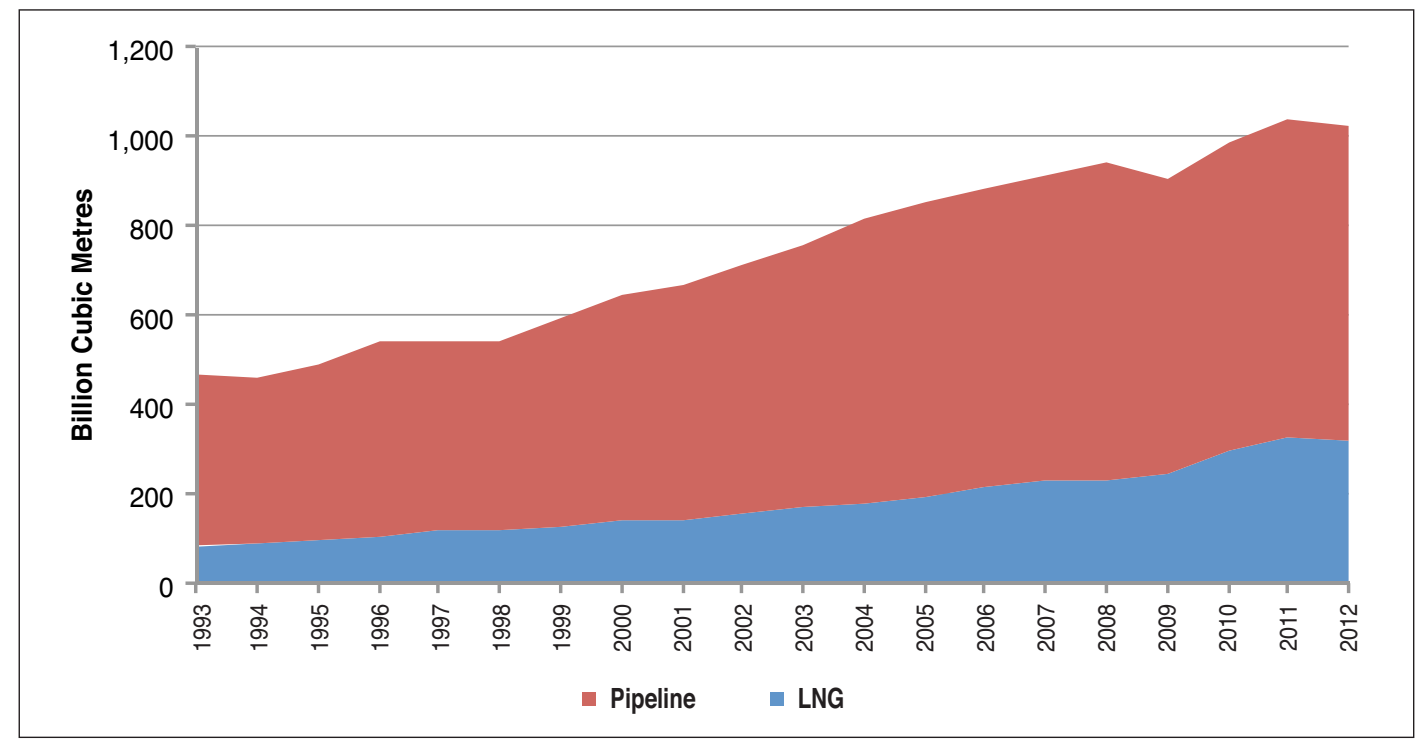

Source: IEA, “World - Natural Gas imports by origin," IEA Natural Gas Information Statistics (database), 2013, doi: 10.1787/data-00555-en.

\subsubsection{WORLD LNG-RECEIVING TERMINALS}

LNG facilities delivering natural gas to the marketplace rely on specialized shipping to move product between tidewater ports. Regasification terminals receive natural gas, expand the gas from its liquid state, and store or transfer it via pipeline to client storage. These facilities allow it to come back to normal conditions of temperature and pressure before being used.

Regasification facilities are dispersed throughout the world, with slightly less than two-thirds of capacity in 2013 concentrated in Japan, South Korea and the U.S. (Figure 3.8). At the end of 2013, there were 100 regasification terminals in the world with a total regasification capacity of 689 million tonnes per annum. There is some expected growth in regasification capacity, with 94.6 MMTPA expected to be added by 2018, a 14 per cent increase.$^{66}$ However, 273 MMTPA in total is under construction, proposed or announced. A new development in this market is that Singapore and Malaysia are scheduled to construct their first import terminals by 2017. In addition, Indonesia - currently an LNG exporter - is constructing its first import terminal, also expected to be completed by $2017 . .^{67}$

\footnotetext{
${ }^{66}$ The increase in capacity is based on terminals under construction between 2013 and 2018, identified in Appendix F.

${ }^{67}$ Indonesia, Singapore and Malaysia are further discussed in Appendix B.
} 
FIGURE 3.8: REGASIFICATION CAPACITY BY COUNTRY IN 2013 AND 2018 (MMTPA)

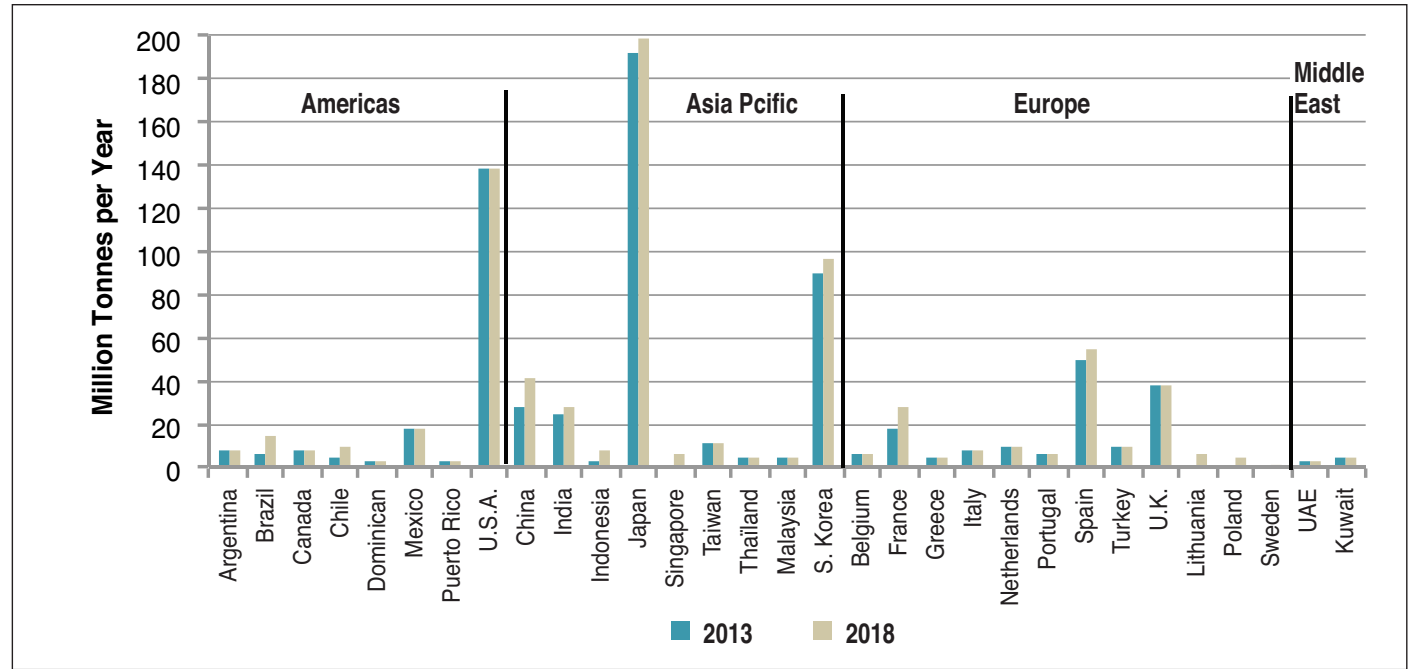

Note: Additional capacity for 2018 includes only regasification facilities currently listed as under construction, and does not account for proposed conversions to export terminals.

Source: See Appendix F

Historically, global utilization of existing LNG import terminals has been under 50 per cent due to the seasonal nature of many markets, and because gas infrastructure is not integrated in many countries. Utilization fell to 37 per cent in 2012 as a result of expanded capacity and slumping demand in Europe and the U.S. ${ }^{68}$

\subsection{World Supply Sources}

According to the EIA, LNG shipments are expected to more than double from about 280 billion cubic metres (205.8 MMT) in 2010 to around $560 \mathrm{BCM}$ (411.6 MMT) in 2040. ${ }^{69}$ Most of the increase in liquefaction capacity is expected in Australia and North America. The EIA notes that world LNG flows adjusted quickly to accommodate Japan's increased demand, postFukushima, showing greater flexibility compared to past demand or supply swings. The EIA predicts that an LNG trade surge will occur between 2015 and 2025, as planned and underconstruction projects in Australia, Canada and the U.S. come online. ${ }^{70}$

\subsubsection{WORLD LIQUEFACTION FACILITIES}

LNG liquefaction facilities are located on all continents except Antarctica. Prior to 2000, LNG was primarily sourced from North Africa, Southeast Asia and the Persian Gulf. Since 2000, LNG capacity has been installed in Eastern Russia, West Africa, South America and the Caribbean. In addition to these regions entering the LNG market, significant growth in capacity has occurred in the Persian Gulf and Australia. Currently, Qatar has the largest liquefaction capacity of any country, followed by Indonesia, Malaysia and Australia.

\footnotetext{
${ }^{68}$ International Gas Union, World $L N G$.

69 EIA, International Energy Outlook 2013, "Natural Gas," http://www.eia.gov/forecasts/ieo/nat_gas.cfm.

70 ibid.
} 
In order to meet growing demand for natural gas in areas without sufficient domestic production or pipeline connections, additional liquefaction capacity is required from current and potential exporters. As illustrated in Figure 3.9, the increase in liquefaction capacity is regional and incremental in nature. For most countries, there is no projected growth in capacity; the stable nature of their facilities also illustrates the stable and - for most limited growth in new contracts for delivery. A major exception is the growth in capacity in Australia, which is poised to surpass Qatar as the biggest LNG exporter in the world.

Australia's huge natural gas resources dwarf the domestic demand for those resources. The U.S. will also become a major exporter in the next decade, with 16 proposed export projects, but most of these projects will not start producing until after $2018 .^{71}$

\section{FIGURE 3.9: LIQUEFACTION CAPACITY BY COUNTRY IN 2013 AND 2018 (MMTPA)}

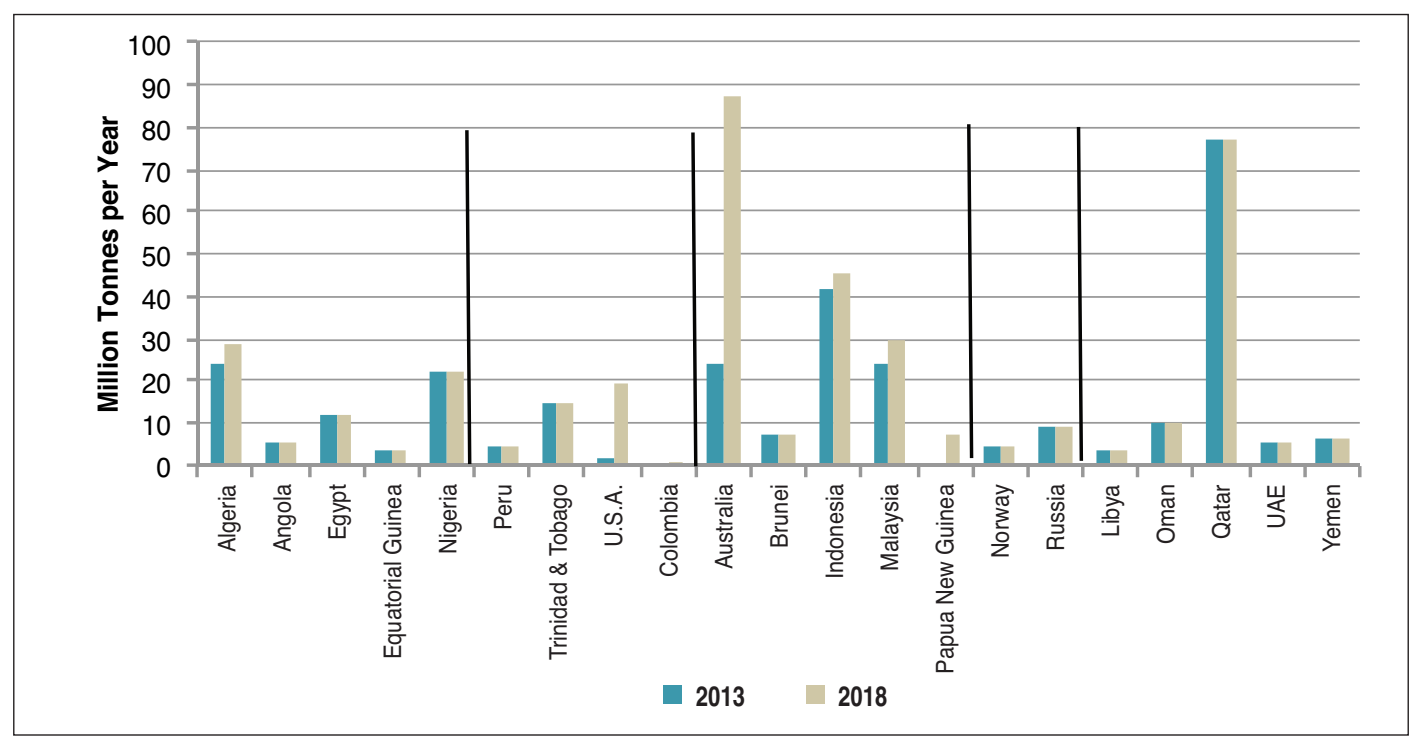

Note: Capacity additions in 2018 reflect projects currently under construction, and do not account for conversions to regasification, nor include speculative terminals.

Source: See Appendix E.

The capacity additions shown in Figure 3.9 bring world export capacity to 406 MMT; this is only slightly smaller than the EIA's projected world LNG trade of 411.6 MMT in 2040. As these additions are only projects currently under construction, the aggregate global capacity of proposed liquefaction projects appears to exceed the growth in projected global LNG demand. As a consequence, many of the proposed projects will not be realized or may get delayed for an extended period of time.

71 As of March 26, 2014, only Sabine Pass had FERC approval to export LNG (and is the only facility under construction); future approvals may be limited by political pressure or industry-association lobbying and a desire to keep domestic natural gas prices low. (Federal Energy Regulatory Commission, "North American LNG Import/Export Terminals Approved," news release, http://www.ferc.gov/industries/gas/indus-act/lng/lngapproved.pdf). 


\subsubsection{WORLD LNG SHIPPING}

The LNG shipping industry has grown apace with the growth of LNG trade. At the end of 2013, there were 393 vessels in the global LNG fleet, ranging in age from one to 44 years, with an average age of 12 years. ${ }^{72}$ The average ship capacity of the existing fleet is 143,200 cubic metres. ${ }^{73}$ The LNG vessel order-book is for 113 vessels, 98 with a capacity over 50,000 CM. ${ }^{74}$ Tanker efficiency, capacity and safety features such as double hulls are critical for overall industry performance and compliance with rules and standards. The ships designed for transportation of super chilled natural gas have evolved not only in terms of containment vessel stability, but also in the added capability to serve propulsion systems using on board stored natural gas. The result eliminates the need for bunker fuel oil and improves overall air emissions. An illustration of the design is shown in Figure 3.10. The tanker on the right uses LNG as fuel, whereas the tanker on the left has onboard bunker fuel.

\section{FIGURE 3.10: LNG TANKER}

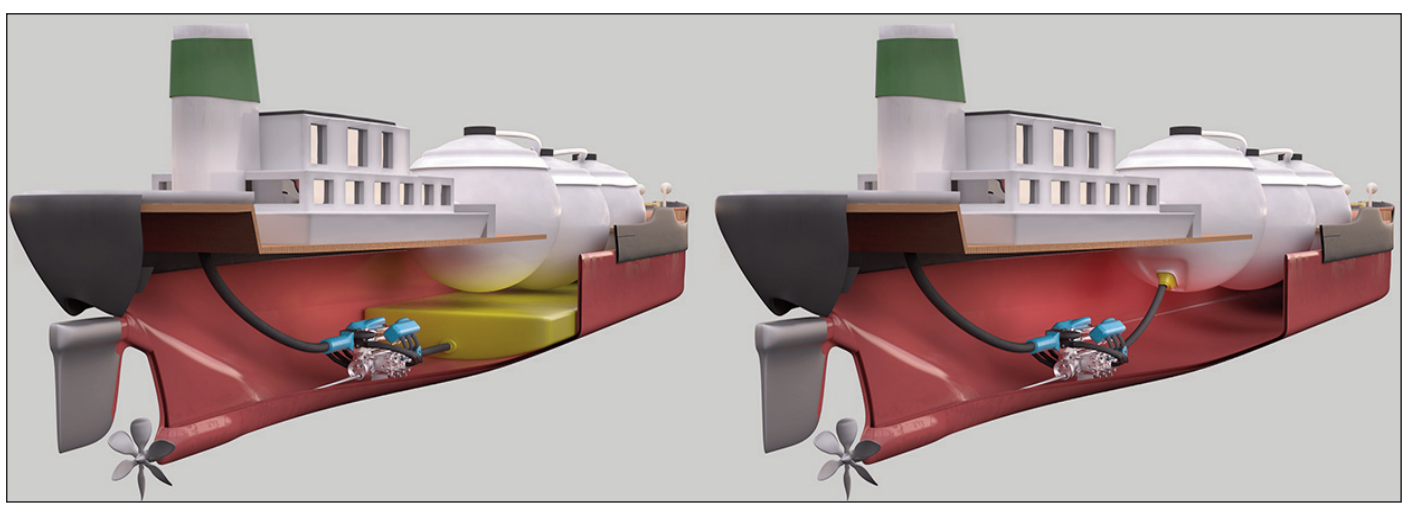

Fewer than seven per cent of the ships in the existing global fleet are able to transit the Panama Canal, ${ }^{75}$ the 77 -kilometre long shortcut from the Caribbean to the Pacific. However, the canal expansion project currently underway will create a deeper and wider third lane and a new system of locks to accommodate much larger ships. Once the expansion is completed in 2015, most of the global LNG fleet will be able to transit the canal, reducing voyage distances from the U.S. Gulf Coast to Asia by 5,000 to 7,000 nautical miles (depending on the route taken) vis-à-vis voyages around Cape Horn. Only the biggest Q-Flex $(210,000 \mathrm{CM}-216,000 \mathrm{CM})$ and Q-Max (266,000 CM) ships will not be able to transit the canal.

LNG shipping costs influence LNG trade flows and LNG pricing dynamics. Shipping costs are a key driver of the value created by moving gas between locations and the price spreads between regions in the global LNG trade. Shipping costs play a critical role in decisions to divert cargoes to higher-priced markets, and are also a key consideration in understanding the extent to which global prices may converge in the future. ${ }^{76}$

\footnotetext{
72 International Group of Liquefied Gas Importers (GIIGNL), The LNG Industry in 2013 (Paris: GIIGNL, 2013), http://www.giignl.org/publications/lng-industry-2013.

73 ibid.

74 ibid.

75 ibid.

76 Timera Energy blog, "Getting to grips with LNG shipping costs", September 16, 2013, http://www.timeraenergy.com/continental-gas/getting-to-grips-with-lng-shipping-costs/.
} 
As a result of the industry's inability to time the construction of new ships precisely in line with shipping requirements, there are periods when there is an oversupply or an undersupply of shipping capacity. The mismatch between shipping capacity and requirements is exacerbated when shipping patterns (routes) shift unexpectedly, as they did in 2011 when LNG demand in Europe fell and demand in Japan suddenly increased. Short-haul voyages became long-haul voyages, absorbing shipping capacity. In 2011, demand for spot cargoes, particularly in Japan and South America, propelled short-term charter rates higher. Spot charter rates rose from $\$ 30,000$ to $\$ 50,000$ per day in mid-2010, to a peak of about $\$ 150,000$ per day in mid-2012. ${ }^{77}$

In mid-2012, as incremental demand for spot cargoes began to subside in North Asia and outages occurred at key LNG export plants - freeing up shipping capacity - spot charter rates started to fall. By October 2013, spot charter rates had fallen to a yearly low of about $\$ 95,000$ per day for $160,000 \mathrm{CM}$ ships. ${ }^{78}$ However, the majority of charter party contracts for five years or more continue to be at around $\$ 80,000$ per day. ${ }^{79}$

Given the pace at which new export and import projects are being constructed, the rapid expansion of the LNG shipping fleet, and developing market phenomena such as the reexporting of LNG, make the tracking and accounting for LNG trade flows more complicated. Combined, all of these are making the LNG trade increasingly more dynamic, flexible, liquid and competitive.

\subsection{LNG and Associated Costs}

The demand for natural gas continues to grow annually, and it is growing worldwide. This trend is linked to gas-turbine power generation displacing coal and nuclear facilities and serving new demand. This power generation source creates lower emissions, is relatively inexpensive to install and has high demand-responsive rates. In developing countries, such as those in the Asia-Pacific region, cost effective access to these supplies is only possible via LNG shipments. Since the cost of regasification terminals is competitive, entering long-term contracts for shipments of natural gas through tidewater ports is an attractive strategy for energy security and economic development.

The system needed to support natural gas development, transport, processing, shipping and regasification is highly co-ordinated between producers, pipeline owners, facility operators, shipping companies and finance agents. The oversight and approval by government agencies does not end with pipeline siting and well development, but continues with oversight, inspection and ultimately marine-safety programs.

The price of the delivered gas depends, consequently, on a similar sequence of elements of the pipeline system from wellhead to pipeline, liquefaction, shipping and, ultimately, regasification at delivery ports. Expansion or improvement of any point on the system will be dependent on long-term contract arrangements with clients rather than merchant investment in submarkets such as pipelines.

\footnotetext{
77 International Gas Union, World $L N G$.

78 Poten \& Partners, "Weekly LNG Spot Shipping Report”, October 4, 2013.

79 International Gas Union, World LNG.
} 


\subsubsection{TIDEWATER LNG SHIPPING PORT FACILITIES (LIQUEFACTION)}

A critical link in the natural-gas-to-delivered-market chain is the nature and cost of tidewater port facilities. In this paper we do not make a judgment as to which facilities are likely to be approved, their ultimate size beyond a critical minimum, and competition with interested development companies. Rather, we assume a model plant for illustration, which would to be scalable with consistent access to new supplies, electrical power and wharfing facilities. For consistency, we have assumed that each plant is capable of processing two trains of natural gas at a rate of 4.5 MMTPA per train.

\section{FIGURE 3.11: LNG PORT FACILITIES}

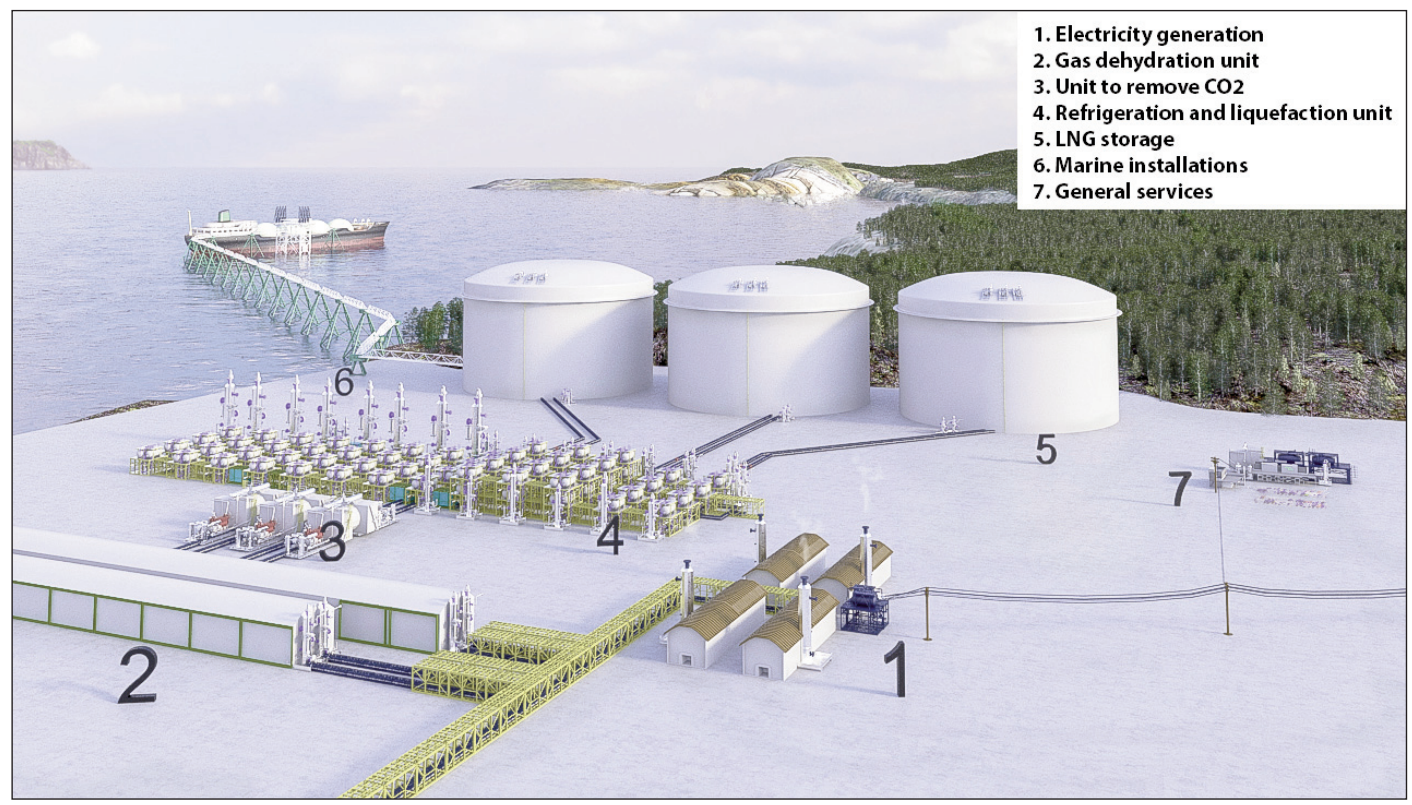

Source: Adapted from Repsol, "Repsol starts up its first gas liquefaction plant in Latin America," press release, June 10, 2010, http://www.repsol.com/es_en/corporacion/prensa/notas-de-prensa/ultimas-notas/10062010Repsol-planta-licuefaccion-latinoamerica.aspx.

The illustration in Figure 3.11 shows the overall facilities at a typical liquefaction plant. The LNG train, and storage components and export terminals, typically require either electrical-grid access or onsite power generation. Lastly, a jetty is necessary for the LNG tankers to berth and receive and load the LNG product.

\subsubsection{Tidewater Port Development Locations and Costs}

Waterborne transport is an extremely efficient means of moving heavy cargo, and for transportation of a fuel such as natural gas in the form of LNG, it is the only feasible method of long-distance movement in the absence of pipelines. In general, the historical market for LNG has been based on dedicated bi-lateral contracts from port to port. In the case of existing shipments to the Asia-Pacific region, the bulk of transfers are based on contracted flows, with little activity in the form of spot-market trades. This characteristic highlights the reliance of the market on limited port facilities and shipping capacity sized to match contract demands that are, in turn, matched to dedicated sources of supply.

Recent years have seen some growth in the use of spot or short-term contracts in the Asia-Pacific region, largely in response to dramatic demand shifts from Japan. Some of the spot-market 
activity may also reflect surplus capacity that can be made available to ship to those ports with new and expanding regasification facilities that are not fully covered by existing contracts. ${ }^{80}$

\subsubsection{Cost of Plant}

In order to viably transport natural gas via tanker, its volume must be greatly reduced. This is accomplished through the process of liquefaction at the site of export. By cooling natural gas to a temperature of approximately $-162{ }^{\circ} \mathrm{C}$, the gas condenses to a liquid state occupying roughly $1 / 600$ th the original gaseous volume at room temperature.

The cost of a plant can be split into two components: the capital cost associated with construction and the variable operation costs. As noted above, the capital costs of liquefaction facilities are substantial. Figure 3.12 plots capital cost per tonne of capacity for various projects in 2012 dollars, also adjusted for exchange-rate fluctuations. The average cost per tonne of operating terminals is $\$ 998$ (2012 USD); the under-construction terminals have an expected average cost double that of operating terminals at $\$ 1,896$ (nominal USD)/tonne. Proposed terminals (not shown) have an average cost of $\$ 1,430 /$ tonne, suggesting that initially reported capital costs may be an underestimate. IHS CERA tracks construction costs in a variety of industries, including LNG, refining and petrochemicals, and power generation plants. ${ }^{81}$ According to these indices, construction-cost increases appear to be a general trend worldwide and are not a phenomenon only in LNG projects.

FIGURE 3.12: LNG CAPITAL COST PER METRIC TONNE

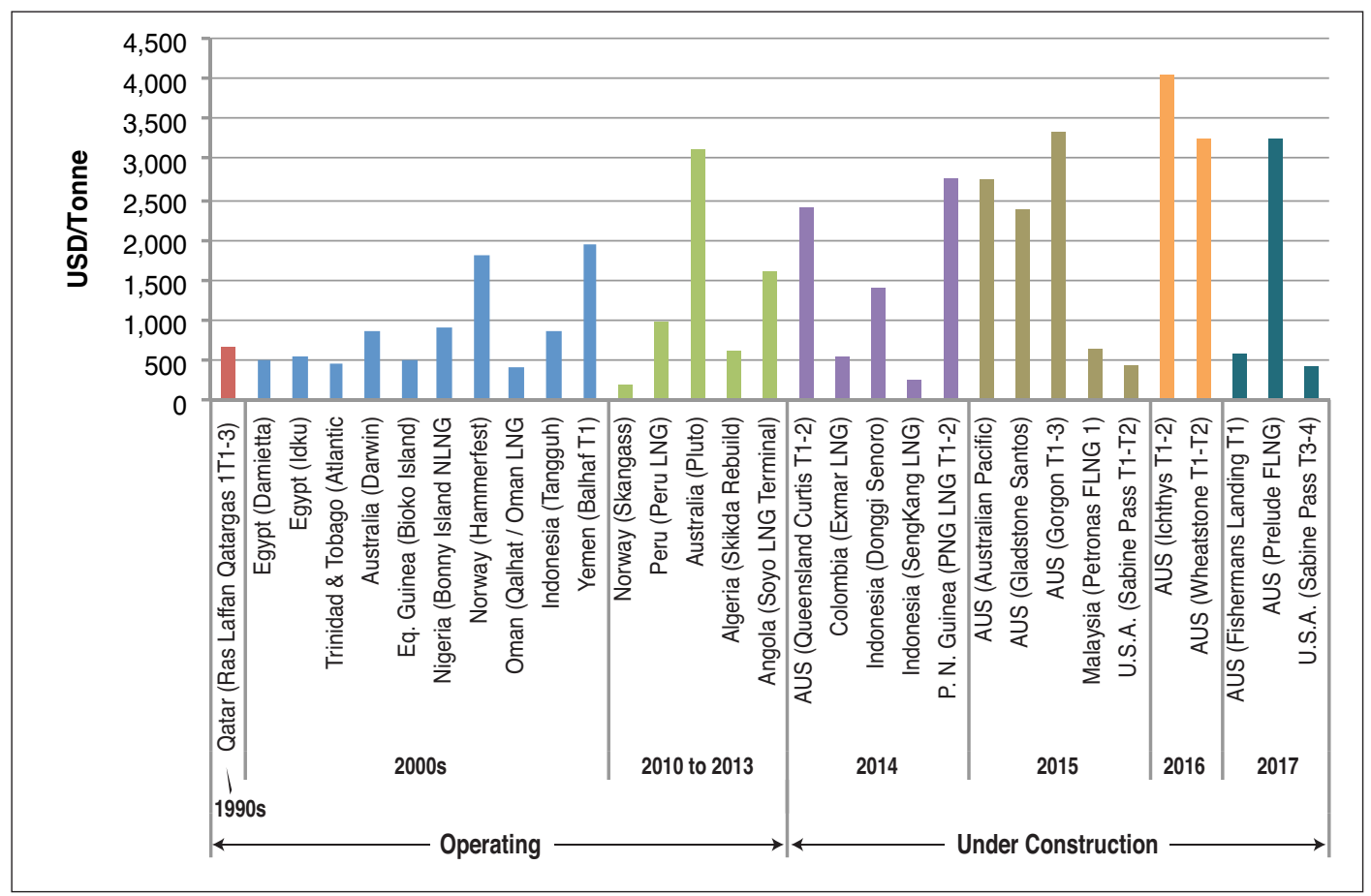

Note: Costs for operating terminals adjusted for inflation- and exchange-rate changes between completion year and 2012. Under-construction terminal costs are in nominal dollars.

Source: See Appendix E.

${ }^{80}$ Extensions on the primary term of contracts are not unusual in the industry. A contract may provide for automatic extensions after a period for a set number of years, at the option of the buyer or seller, depending on initial terms and the market forecast. M.D. Tusiani and G. Shearer, LNG: A Nontechnical Guide (Tulsa, Ok.: PennWell, 2007).

81 IHS website, “Costs \& Strategic Sourcing," http://www.ihs.com/info/cera/ihsindexes/index.aspx. 
Many proposed and under-construction export terminals have the estimated cost-of-plant data available; these facilities have an average cost estimate of approximately $\$ 1,577$ per metric tonne of annual LNG export capacity. Figure 3.13 reflects the wide range of cost versus capacity worldwide. Panel A shows costs by status, while Panel B shows costs by location.

\section{FIGURE 3.13: CAPITAL COST PER TONNE OF CAPACITY FOR EXPORT TERMINALS}

PANEL A: LIQUEFACTION TERMINAL COSTS BY STATUS

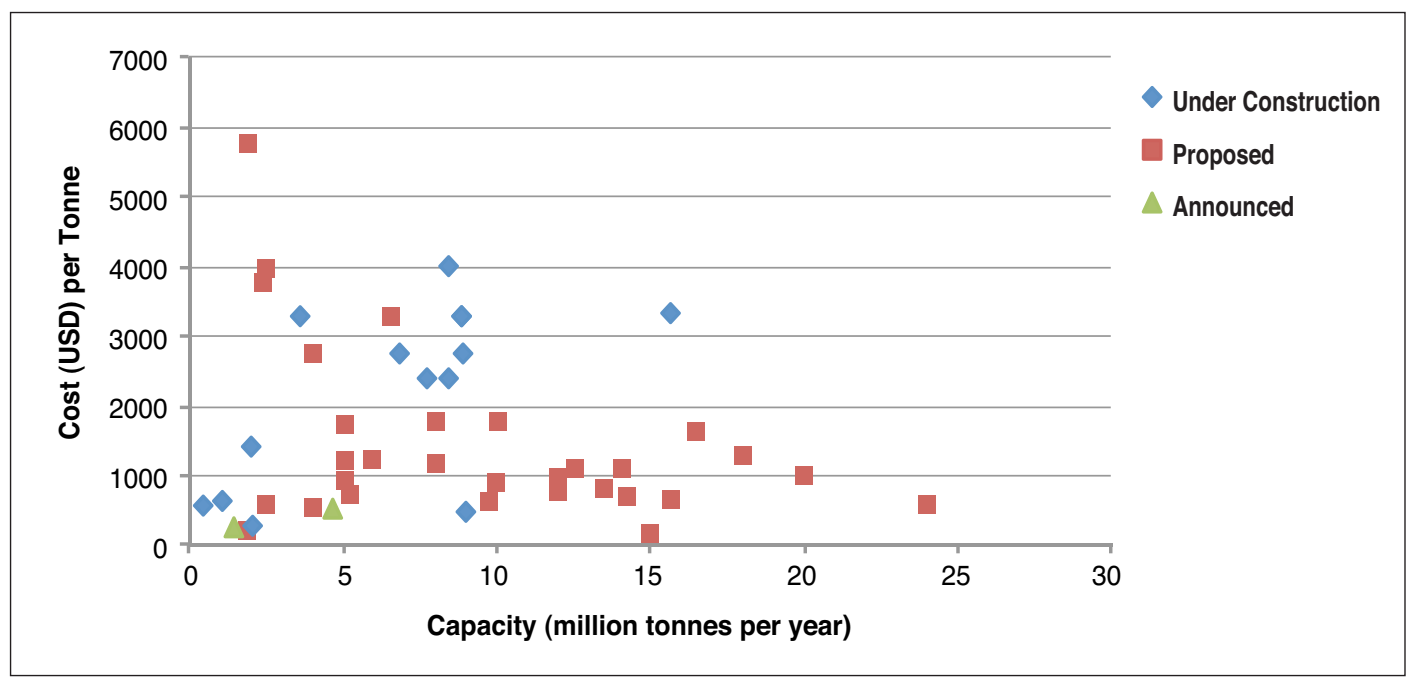

PANEL B: LIQUEFACTION TERMINAL COSTS BY LOCATION

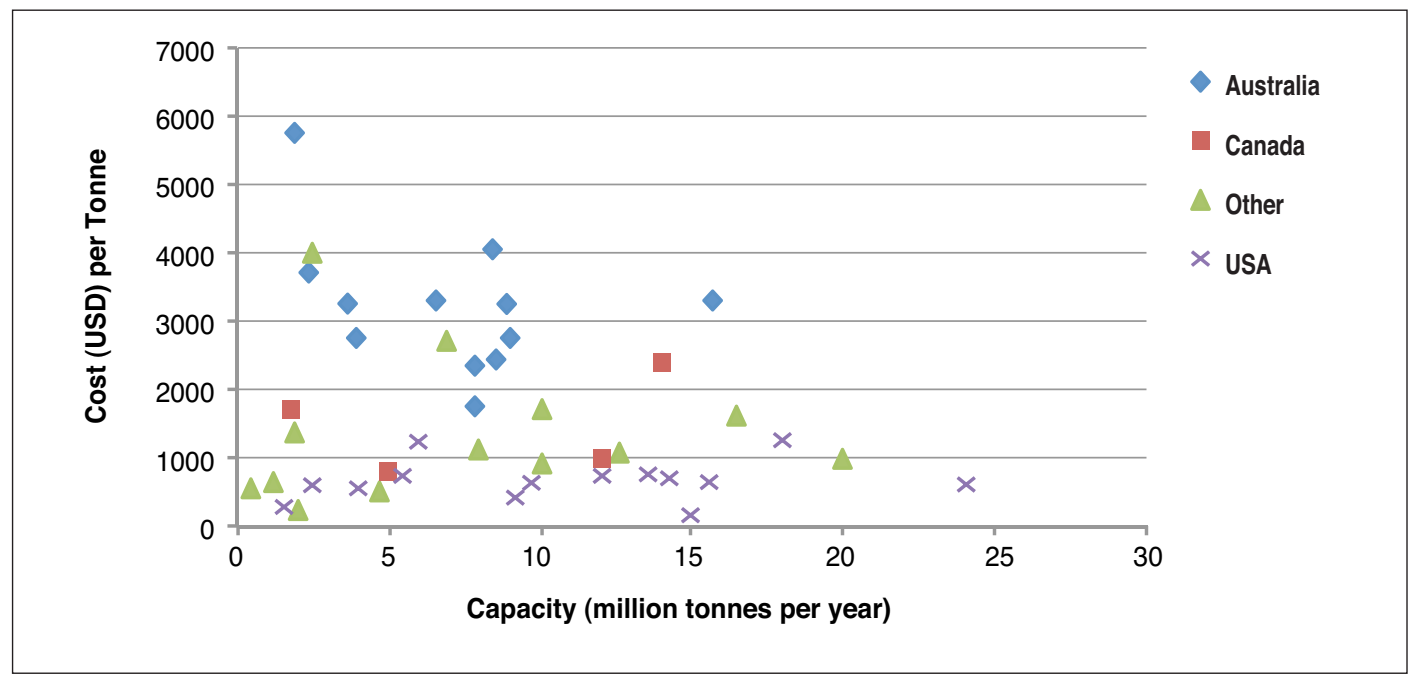

Notes: "Proposed" LNG projects are those where a source was available for cost, capacity and start year, while "announced" are projects where a source was available for start year and capacity, and where there is no evidence of cancellation. Projects without a start year, cost or capacity are not included in the figure.

Source: Authors' calculations based on various sources. See Appendix E for sources.

As suggested above, in this paper we assume a base train-production rate of 4.5 MMTPA (million tons per annum) of LNG with two trains per facility. This number is used for comparison and addresses only the LNG liquefaction portion of the LNG system. 
Regasification facilities will be sized relative to import demand and the regional distribution system involved. Overall, our stylized export facility includes:

- production rate of 9 MMTPA of LNG,

- 95 per cent plant availability,

- average ambient temperature of $22^{\circ} \mathrm{C}$,

- gas-turbine supplied electricity, drivers and air-cooling. ${ }^{82}$

Even with all these elements, each LNG plant will be unique to a specific location and market destination. ${ }^{83}$ Construction of new terminals will be a function of land use and access approvals, construction timing (estimated to be between four and six years per facility depending on starting dates), marine-safety capability, labour-force commitments and ship availability. The construction-cost distribution for a Canadian unconventional gas-fed (shale or coal-bed methane) LNG plant is shown below.

\section{TABLE 3.2: COST DISTRIBUTION FOR A TWO-TRAIN 10.3 MMTPA CANADIAN LIQUEFACTION FACILITY} (\$US BILLION, 2012)

\begin{tabular}{|l|c|c|c|}
\hline & Site Infrastructure & Train 1 & Train 2 \\
\hline Project management labour & 0 & 1.95 & 1.65 \\
Construction labour & 0.82 & 3.09 & 2.67 \\
Engineering labour & 0 & 1.03 & 0.93 \\
Rental equipment & 0 & 0.21 & 0.10 \\
Installed equipment & 0.21 & 0.72 & 0.62 \\
Materials & 0.10 & 0.93 & 0.72 \\
Contingency & 0 & 1.03 & 0.82 \\
Other & 0 & 0.93 & 0.82 \\
\hline Total & $\mathbf{1 . 1 3}$ & $\mathbf{9 . 8 7}$ & $\mathbf{8 . 3 3}$ \\
\hline
\end{tabular}

Source: Michael Ellis, Christiaan Heyning and Olivier Legrand, Extending the LNG boom: Improving Australian LNG productivity and competitiveness (McKinsey \& Company, May 2013), 37, Appendix 3, http://www.mckinsey.com/global_locations/pacific/australia/en/latest_thinking/extending_the_Ing_boom; currency converted from Australian dollars to U.S. dollars using the conversion rate found on page 4, box 2.

Turning to the operational components of liquefaction facilities, the basic layout of LNG liquefaction plants and the gas conversion process is fairly standard; export terminals primarily differ only in regards to size and capacity as described above. The compression and chilling process is standardized as well. First, the natural gas must be supplied to the liquefaction plant via pipeline. Once at the plant, the gas is treated to remove $\mathrm{CO}_{2}, \mathrm{~N}_{2}$, mercury, $\mathrm{H}_{2} \mathrm{~S}$, water, and other liquids. This purification is in addition to the initial treatment that natural gas undergoes near the wellhead to make it suitable for pipeline transport. Once treated, the purified gas is then refrigerated until transformed to its liquid form; at this point it is stored and prepared for

${ }^{82}$ We have assumed that all electrical facilities will be located on site (i.e., not grid dependent) and will utilize gas turbines served by main pipeline gas supplies that consequently must be sized to meet this additional load. We assume that each facility will need approximately $750 \mathrm{MW}$ of capacity to include reserves, for each two trains of capacity.

83 McKinsey \& Company compare LNG projects in Australia to Canada and Mozambique, and found that costs are approximately 20 to 30 per cent higher in Australia. Michael Ellis, Christiaan Heyning and Olivier Legrand, Extending the LNG boom: Improving Australian LNG productivity and competitiveness (McKinsey \& Company, May 2013), http://www.mckinsey.com/global_locations/pacific/australia/en/latest_thinking/extending_the_lng_boom. 
loading onto a tanker. LNG export terminals are built based on modular construction of the preceding processes, referred to as "trains." Most LNG export terminals have more than one train, which are capable of operating in tandem. For this report, in order to provide order of magnitude comparison between future facilities, we have arbitrarily assumed that each port terminal will utilize two trains of fuel annually.

There is considerable loss of gas volume -20 to 30 per cent - associated with the conversion from feed gas to LNG, illustrated in Figure 3.14. The majority of the loss is due to processing and fueling the liquefaction process.

\section{FIGURE 3.14: MAXIMUM TREATING PLANT}

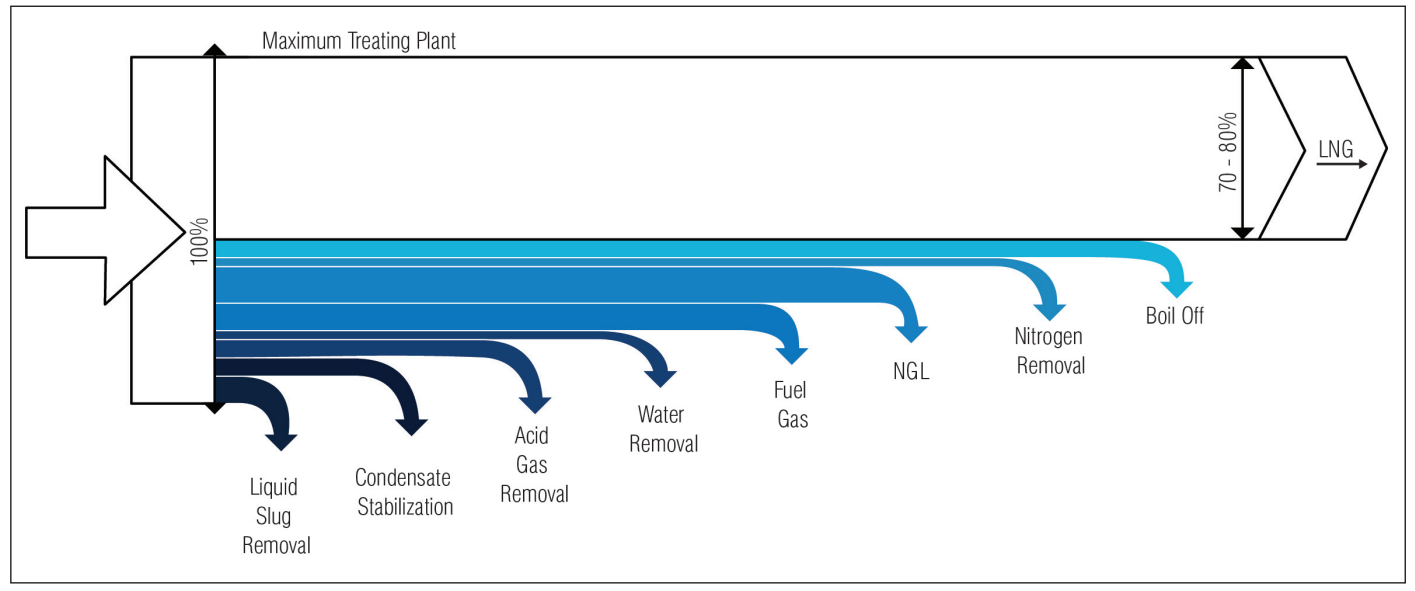

Source: KBR, "LNG Liquefaction - Not All Plants Are Created Equal," Technical Paper, February 2007, http://www.kbr.com/Newsroom/Publications/Technical-Papers/LNG-Liquefaction-Not-All-Plants-Are-Created-Equal.pdf.

Data on operational expenditures are difficult to acquire, though they could undoubtedly be collected via annual reports of various liquefaction projects. Woodside Energy reports that its 16.3 MMTPA North West Shelf project's operating costs are almost \$600 million Australian dollars per year, ${ }^{84}$ or roughly US\$34.60 per tonne. ${ }^{85}$ Tusiani and Shearer suggest that operating expenditures for liquefaction are two to five per cent of the project's total capital cost, though they note that operational expenses are highly dependent on location. ${ }^{86}$ The stated operational expenditures are 2.2 per cent of an "investment amount" of $\$ 27$ billion Australian dollars for the North West Shelf project. ${ }^{87}$ McKinsey \& Company estimate that operational expenditures will be 23 per cent of revenue (\$3.01 USD/MMBTU) for a conventional Australian project, assuming a price of $\$ 13.08 \mathrm{USD} / \mathrm{MMBTU}(\$ 14 \mathrm{AUD} / \mathrm{MMBTU}){ }^{88}$ As Australia and Canada are relatively similar countries, these provide a rough guide to expected operational costs in Canada as well.

\footnotetext{
84 Woodside Energy, "North West Shelf Project," Overview Brochure, http://www.woodside.com.au/OurBusiness/North-West-Shelf/Documents/NWSV\%20Corporate\%20Brochure.PDF.

${ }^{85}$ Using a conversion rate of \$1 USD $=\$ 1.07$ AUD.

86 Tusiani and Shearer, LNG: A Nontechnical, Chapter 11.

87 Woodside Energy, "North West Shelf."

88 Ellis, Heyning and Legrand, Extending the LNG, 5, Exhibit 1. Exchange rate used is \$1 USD = \$1.07 AUD.
} 
While liquefaction plants require pipelines for feed gas, these are generally considered to be separate capital investments. ${ }^{89}$ The capital cost of the pipelines will be rolled into the transportation charge from wellhead to destination, and will be part of the cost to deliver gas to the liquefaction facility. The cost of feed gas is, of course, part of operational expenses.

\subsubsection{Gas Turbines and Electricity}

Access to consistent and reliable electric power is critical for LNG facilities that must operate continuously for chilling, storing and compressing gas supplies as well as support facilities. A high reliability requirement is based on two key elements: the need to support a rapid turnaround for loading ships and the need to maintain constant refrigeration in order to sustain a stable environment for liquid gas.

The base demands for electric power consequently are established by a combination of power supplied for system operations plus reserve power for unforeseen upsets as well as routine maintenance. There are two primary methods of achieving appropriate levels of service and redundancy. First, a standalone system can be developed at the port facility using the gas (parasitic load) supplied for liquefaction needs. Second, grid-based connections, when close enough to high-voltage regional transmission systems, can offer power in a bilateral contract with provisions to "net" usage from surplus generation, although most facilities using grid power will also develop backup facilities to cover occasional grid outages.

\subsubsection{LNG DELIVERY PORT FACILITIES (REGAS)}

Natural gas must be refrigerated and liquefied at the site of export to make it dense enough such that tanker transportation becomes economically viable. Once an LNG-laden tanker arrives at an import terminal, the LNG is offloaded to insulated storage containers. Despite the insulation, the LNG continually regasifies and must either be re-liquefied, delivered, or flared. When needed, the LNG is pumped through a vaporization system that increases the temperature of the liquefied product through the use of a heat exchanger utilizing seawater, or gas-fired heating. Now in its gaseous state, the natural gas is odorized and delivered to the pipeline, ready for consumption.

Though regasification terminals are significantly cheaper to construct than their liquefactioncapable counterparts, pre-arranged supply contracts and significant capital are still necessary to undertake construction. Lower capital costs for regasification terminals are the result of a combination of factors. The plants themselves are less complicated, and require far less power to operate. They are typically located closer to demand centres and, as a result, construction is cheaper, logistics are more manageable, and often only short connecting pipelines need be built. The capital cost disparity is reflected in the per-unit levies, with regasification typically costing between $\$ 0.29 / \mathrm{GJ}$ to $\$ 1.90 / \mathrm{GJ}$ ( $\$ 0.30 / \mathrm{MMBTU}$ to $\$ 2.00 / \mathrm{MMBTU})$, and liquefaction more expensive at $\$ 2.81 / \mathrm{GJ}$ to $\$ 5.04 / \mathrm{GJ}(\$ 2.96 / \mathrm{MMBTU}$ to $\$ 5.30 / \mathrm{MMBTU}) .{ }^{90}$

${ }^{89}$ For example, while many of the B.C. LNG project proponents are looking for partnerships with pipeline companies, the feed pipelines will not be owned by the LNG projects. See: LNG Canada, "TransCanada Selected by Shell and Partners to Develop Multi-Billion Dollar Natural Gas Pipeline to Canada's West Coast,” News Release, June 5, 2012 , http://lngcanada.ca/news/transcanada-selected-by-shell-and-partners-to-develop-multi-billion-dollar-natural-gaspipeline-to-canadas-west-coast/.

90 PFC Global Energy cites \$0.40/MMBTU as the low end of their range for regasification costs, with \$2.00/MMBTU as the high end (PFC Energy, "Global LNG," 7). Data from Poten \& Partners via Bloomberg (ticker: POTN) has the range of \$0.30/MMBTU to \$0.40/MMBTU; estimates of liquefaction costs come from Table 5.5. 
The cost of regasification is a factor in the overall import cost of natural gas, but it is borne by the importer and charged back to industrial and power users in the importing nation. Although the cost affects the users, it does not reflect on the competitive position or value of the LNG cargo. Other factors may influence the value of the LNG import, such as heat content or purity, but discounts on the cargo still occur on the sea side of the regas facility.

Import terminals are typically sized to match expected domestic growth for the importing nation, a function of the capacity of the distribution network, existing power and heating capability and expected growth in demand. Capital cost per annualized capacity for announced, proposed and under-construction regasification terminals is plotted in Figure 3.15. Most facilities are clustered around costs between $\$ 100$ and $\$ 400$ per tonne. The average cost for terminals plotted in Figure 3.15 is $\$ 300 /$ tonne.

FIGURE 3.15: CAPITAL COST PER TONNE OF CAPACITY FOR IMPORT TERMINALS

\section{PANEL A: REGASIFICATION TERMINAL COSTS BY STATUS}

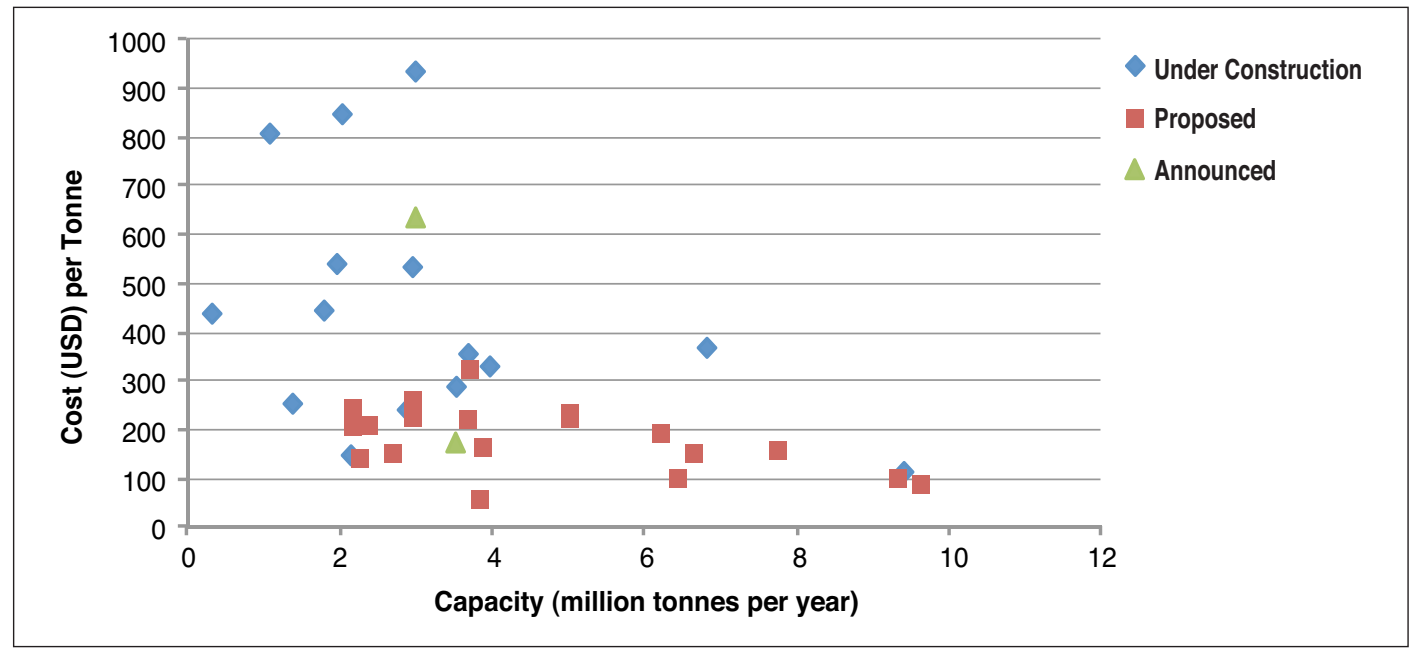

PANEL B: REGASIFICATION TERMINAL COSTS BY LOCATION

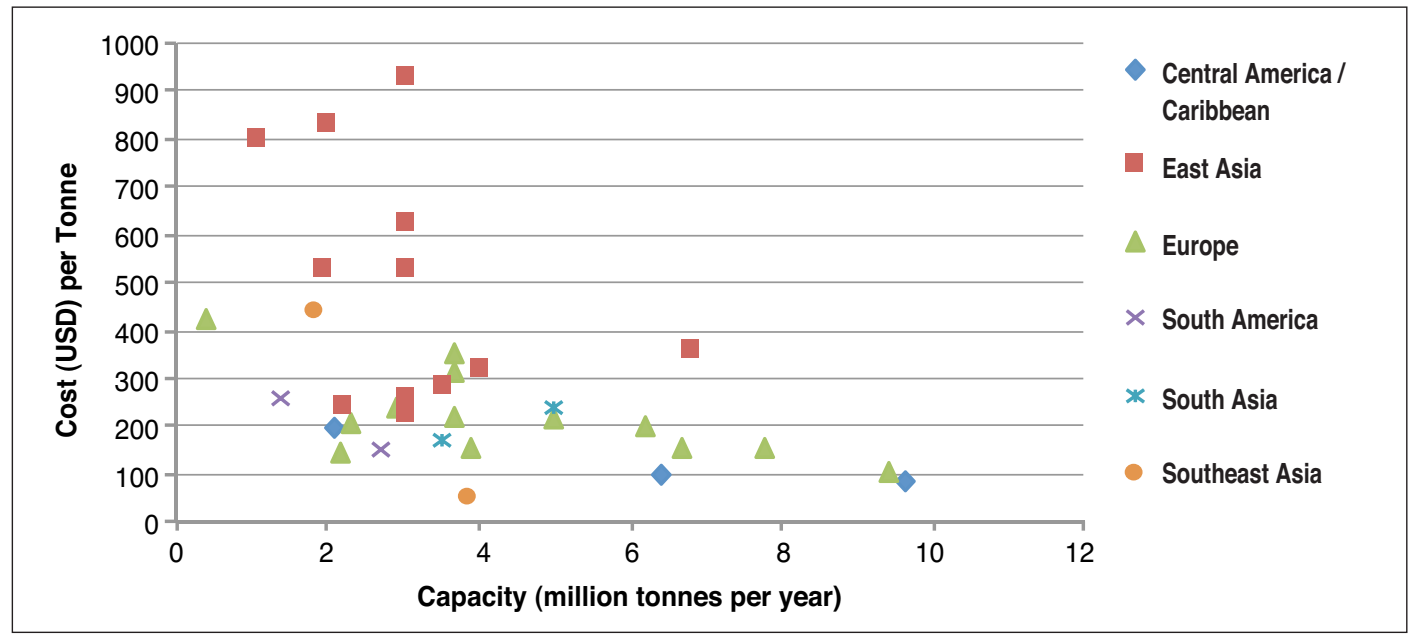

Notes:

"Proposed" LNG projects are those where a source was available for cost, capacity and start year, while "announced" are projects where a source was available for start year and capacity, and where there is no evidence of cancellation. Projects without a start year, cost or capacity are not included in the figure. 


\section{LNG DEMAND IN THE ASIA-PACIFIC REGION}

Largely lacking international pipeline infrastructure and domestic supplies, countries in the Asia-Pacific region have relied on LNG regasification terminals for much of their natural gas supply. Though many terminals are planned and under construction in the region, steady increases in natural gas demand have begun to stress import capacity at various Asian countries. With the exception of China, many Asian importers have experienced stagnant LNG import capacity since at least 2008 . As a result, regasification capacity-utilization has been steadily increasing, reinforcing the need for greater import capacity. The availability of import capacity in the Pacific Basin will prove to be an important catalyst for Canadian LNG export growth.

According to BP, natural gas consumption in the Asia-Pacific region is set to increase to 1,181 $\mathrm{BCM}$ by 2025 , and to $1,328 \mathrm{BCM}$ by $2035 .{ }^{91}$ Production in the Asia-Pacific region will remain below consumption, with the deficit increasing to 372 BCM by 2035 and 514 BCM by 2035 .

Table 4.1 displays the natural gas trade balance by country for the Asia-Pacific region between 2012 and 2025. Growth rates for production and consumption are based on projected regional growth rates from the BP World Energy Outlook 2035. This will overestimate growth in some countries and underestimate growth for others. However, it does serve to illustrate a persistent regional trade deficit.

TABLE 4.1: ASIA-PACIFIC NATURAL GAS TRADE BALANCE (BCM)

\begin{tabular}{|c|c|c|c|c|c|c|c|c|c|c|}
\hline & \multirow{2}{*}{ 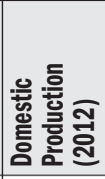 } & \multirow{2}{*}{ 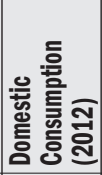 } & \multirow{2}{*}{ 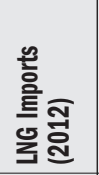 } & \multirow{2}{*}{ 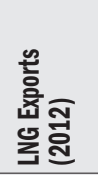 } & \multirow{2}{*}{ 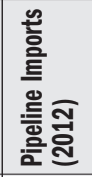 } & \multirow{2}{*}{ 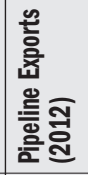 } & \multicolumn{4}{|c|}{ Natural Gas Trade Balance } \\
\hline & & & & & & & 2012 & 2015 & 2020 & 2025 \\
\hline \multicolumn{11}{|l|}{ Asia-Pacific Importers } \\
\hline China & 107.20 & 146.60 & 20.00 & & 24.20 & & (39.40) & $(48.42)$ & (67.15) & (91.63) \\
\hline India & 40.20 & 54.60 & 20.50 & & & & $(14.40)$ & (17.73) & $(24.65)$ & (33.71) \\
\hline Japan & & 116.70 & 118.80 & & & & $(116.70)$ & (132.69) & $(164.36)$ & (203.58) \\
\hline Singapore & & 8.30 & & & 9.50 & & $(8.30)$ & (9.44) & $(11.69)$ & $(14.48)$ \\
\hline South Korea & & 50.00 & 49.70 & & & & $(50.00)$ & (56.85) & $(70.42)$ & $(87.22)$ \\
\hline Taiwan & & 16.30 & 16.90 & & & & $(16.30)$ & (18.53) & $(22.96)$ & $(28.44)$ \\
\hline Thailand & 41.40 & 51.20 & 1.40 & & 8.50 & & $(9.80)$ & (12.54) & $(18.31)$ & (25.94) \\
\hline \multicolumn{11}{|l|}{ Asia-Pacific Exporters } \\
\hline Australia & 49.00 & 25.40 & & 28.10 & 10.90 & & 23.60 & 25.18 & 27.91 & 30.70 \\
\hline Brunei & 12.60 & & & 9.10 & & & 12.60 & 13.90 & 16.37 & 19.29 \\
\hline Indonesia & 71.10 & 35.80 & & 25.00 & & 10.20 & 35.30 & 37.74 & 41.98 & 46.39 \\
\hline Malaysia & 65.20 & 33.30 & & 31.80 & 2.30 & & 31.90 & 34.07 & 37.83 & 41.72 \\
\hline Myanmar & 12.70 & & & & & 8.50 & 12.70 & 14.01 & 16.50 & 19.44 \\
\hline Supply-Demand Balance & & & & & & & $(\mathbf{1 3 8 . 8 0})$ & (171.30) & (238.93) & $(327.46)$ \\
\hline
\end{tabular}

Notes: Supplies increase based on projected regional production and consumption growth rates from BP Energy Outlook 2035. Data for China include Hong Kong.

Source: BP, BP Statistical Review of World Energy June 2013 (2013); BP, BP Energy Outlook 2035 (2013).

\footnotetext{
91 BP, BP Energy Outlook 2035 (2013). Converted from million tonnes of oil equivalent.
} 


\subsection{Asia-Pacific Natural Gas Consumption}

Natural gas consumption in the Asia-Pacific region has grown an average of six per cent year over year for over two decades. ${ }^{92}$ Japan was the largest gas consumer in the region until 2010, when China surpassed Japan as the largest Asia-Pacific gas market.

FIGURE 4.1: NATURAL GAS DEMAND IN ASIA-PACIFIC 1980 - 2012 (BCM)

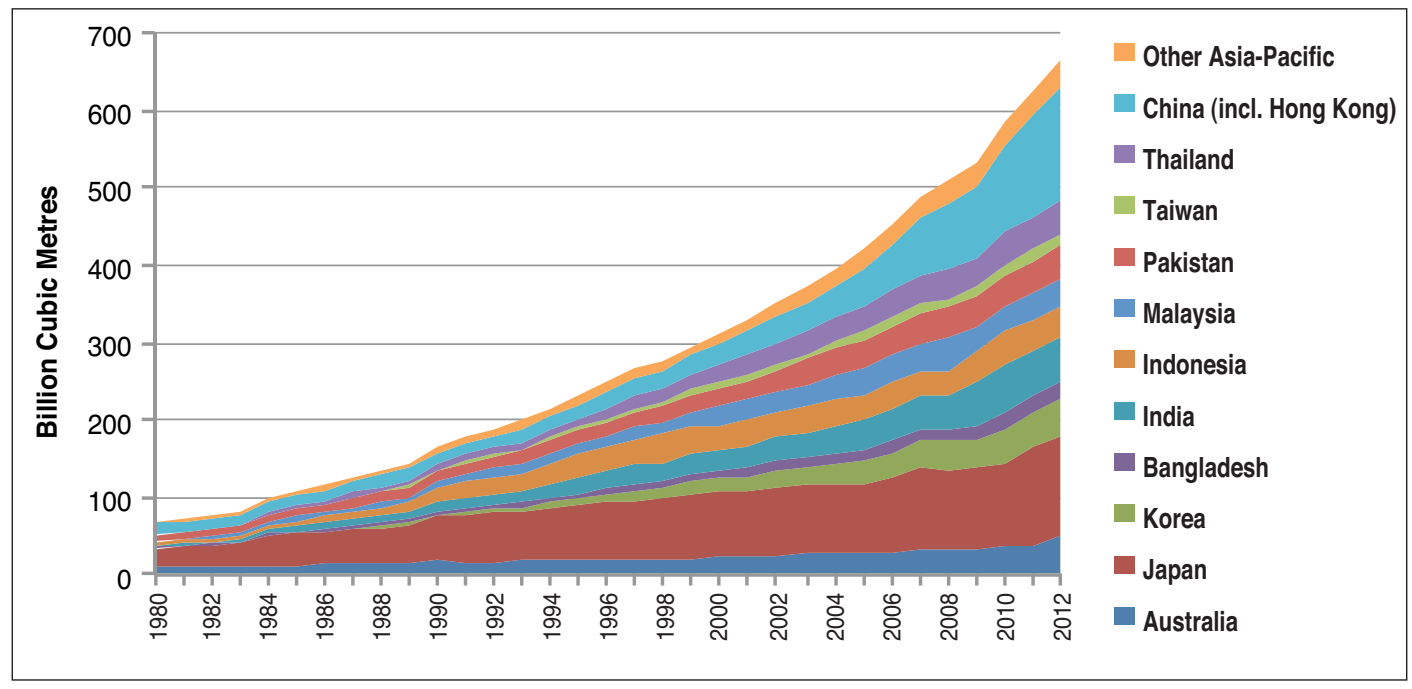

Source: IEA “World - Natural gas statistics," IEA Natural Gas Information Statistics (database), 2013, doi: 10.1787/data-00482-en.

FIGURE 4.2: SECTOR DEMAND FOR NATURAL GAS IN ASIA-PACIFIC 2000 - 2017 (BCM)

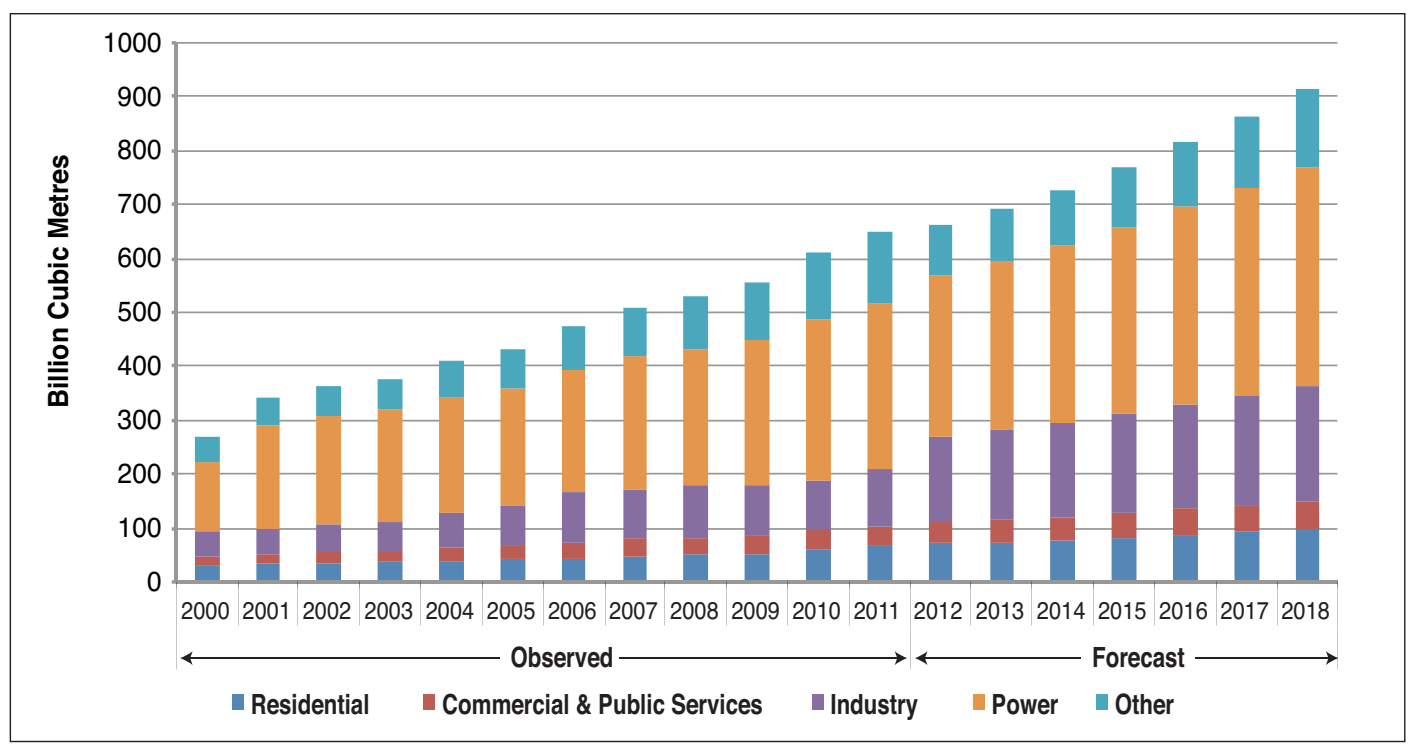

Notes: Source for forecast natural gas use: IEA, "Medium-Term Gas Market Report 2013" (Paris: IEA, 2013), 178, Table 31.

Source for 2000-2011 residential, commercial, industry and other: IEA World Energy Statistics and Balances, elSSN:1683-4240DOl:10.1787/enestats-data-en. Source for 2000-2011 power data: IEA Sankey Diagram, http://www.iea.org/Sankey/. Source for forecast natural gas use: IEA, “Medium-Term Gas Market Report” (Paris: IEA, 2013), 178, Table 31.

92 IEA, Developing a Natural. 
Natural gas consumption in the power sector predominates, accounting for 50 per cent of consumption between 2000 and 2011 (Figure 4.2), compared to residential (10 per cent), commercial and public services (six per cent) and industry (16 per cent). Power's share of total consumption is forecast to fall to 45 per cent beyond 2012 as industrial use increases. ${ }^{93}$ The strongest growth in natural gas use is from the industrial sector, with consumption forecast to double between 2011 and 2018. Natural gas use by residential and commercial and public services is also forecast to grow substantially, by 45 per cent between 2011 and 2018 for both sectors.

\subsection{Asia-Pacific Natural Gas Trade}

Although natural gas traded through pipelines exceeds the trade of LNG on a global basis, within the Asia-Pacific, LNG trade dominates, accounting for 89 per cent of the natural gas trade in the region (Figure 4.3). The share of pipeline-traded natural gas is set to increase to about 18 per cent of the region's trade in 2017, mainly driven by increased Chinese imports from Central Asia and Myanmar, as no other new cross-border pipeline interconnections are anticipated in the near future. ${ }^{94}$

FIGURE 4.3: PIPELINE AND LNG TRADE IN ASIA-PACIFIC 1993 - 2017 (BCM)

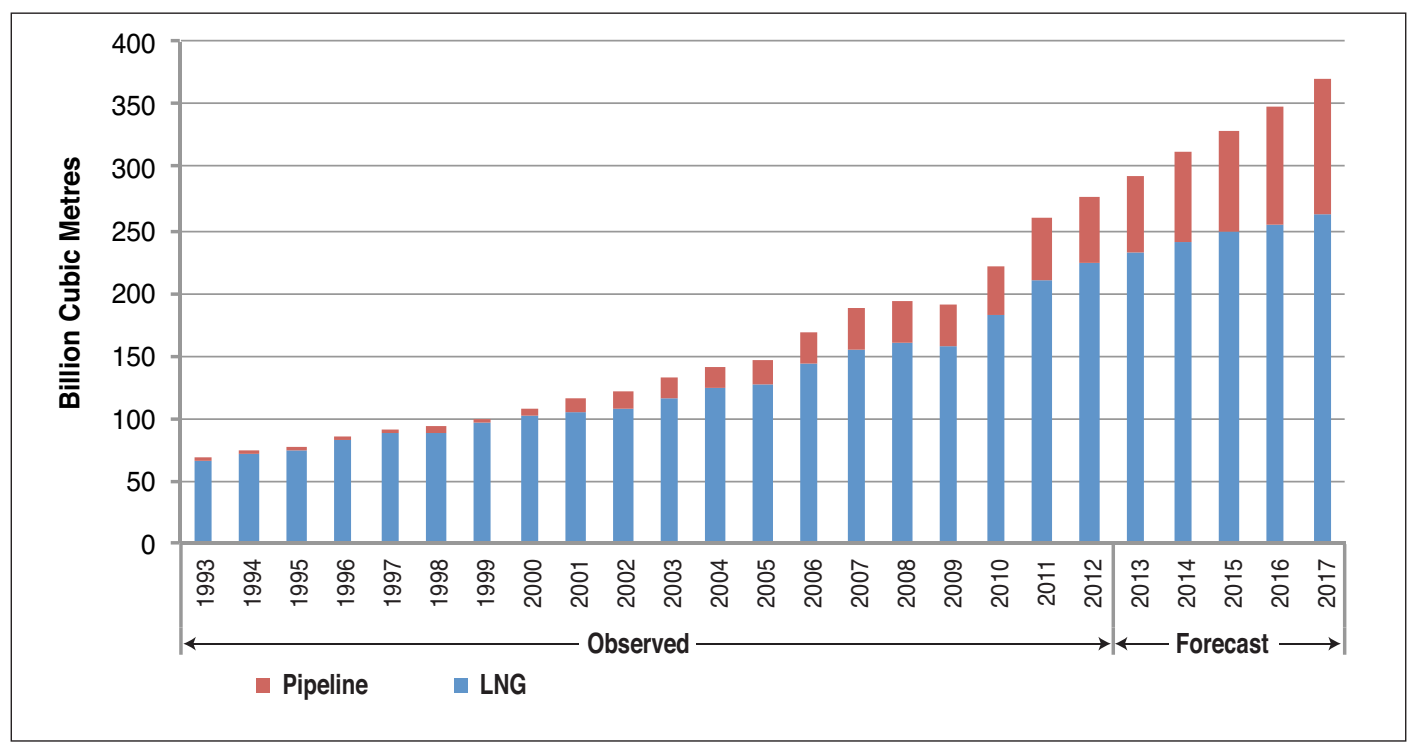

Notes: Forecast based on IEA, Developing a Natural Gas Trading Hub in Asia (Paris: 2013); assume six per cent annual growth for natural gas trade and 15 per cent annual growth for pipeline trade.

Source: IEA, "World - Natural gas imports by origin," IEA Natural Gas Information Statistics (database), 2013, doi: 10.1787/data-00482-en.

\footnotetext{
93 Forecasts are from IEA, Medium-Term Gas Market Report 2013 (Paris: IEA, 2013).

94 IEA, Developing a Natural.
} 


\subsection{Asia-Pacific LNG Supply and Demand}

Six countries in the Asia-Pacific region - Japan, South Korea, Taiwan, China, India, and Thailand -imported LNG in 2012. They imported about 164 MMT, representing 70 per cent of global LNG demand. ${ }^{95}$ About 69 MMT (46 per cent) of this demand was met through intraregional trades, with LNG supplies from regional exporters (Malaysia, Australia, Indonesia and Brunei) to north Asia buyers (Japan, South Korea, Taiwan and China). ${ }^{96}$ This south-to-north, Asia-Pacific intra-regional trade has constituted the majority of the global LNG trade for decades. In recent years, Middle East suppliers have supplanted Asia-Pacific suppliers to the region. Qatar alone supplied 24 per cent of LNG imported by China, Japan, South Korea and Taiwan in 2012. ${ }^{97}$

Qatar is by far the largest LNG exporter in the world, and accounted for 31 per cent of global LNG supply in 2012. Qatar's LNG exports in 2012 reached a record level of 73 MMT, of which 46.5 MMT was shipped to Asia-Pacific countries. ${ }^{98}$ Qatar's significance as an LNG supplier to the region is highlighted by the fact it was the largest supplier of LNG to South Korea, China, India and Taiwan, and Qatar's LNG exports to Japan were only exceeded - just slightly - by shipments from Australia (17.6 MMT versus 15.7 MMT). Malaysia, a distant second to Qatar as an LNG exporter, shipped 23 MMT of LNG during 2012, barely 30 per cent of the quantity supplied by Qatar. ${ }^{99}$ However, all of Malaysia's LNG exports were shipped to North Asia buyers, meeting 14 per cent of the region's demand.

TABLE 4.2: TOP 10 LNG IMPORTERS AND EXPORTERS (2012)

\begin{tabular}{|l|c|c|l|c|c|}
\hline \multicolumn{3}{|c|}{ IMPORTERS } & \multicolumn{3}{c|}{ EXPORTERS } \\
\hline COUNTRY & $\begin{array}{c}\text { Volume } \\
\text { (MMT) }\end{array}$ & $\begin{array}{c}\text { Share (\% of } \\
\text { World Trade) }\end{array}$ & COUNTRY & $\begin{array}{c}\text { Volume } \\
\text { (MMT) }\end{array}$ & $\begin{array}{c}\text { Share (\% of } \\
\text { World Trade) }\end{array}$ \\
\hline Japan & 89.38 & $37.94 \%$ & Qatar & 73.00 & $30.98 \%$ \\
S. Korea & 35.12 & $14.91 \%$ & Malaysia & 23.14 & $9.82 \%$ \\
China & 14.05 & $5.96 \%$ & Australia & 22.20 & $9.42 \%$ \\
Spain & 15.54 & $6.60 \%$ & Nigeria & 19.76 & $8.39 \%$ \\
India & 12.42 & $5.27 \%$ & Indonesia & 17.75 & $7.53 \%$ \\
Taiwan & 12.05 & $5.12 \%$ & Trinidad \& Tobago & 14.58 & $6.19 \%$ \\
U.K. & 10.04 & $4.26 \%$ & Russia & 11.01 & $4.67 \%$ \\
France & 6.65 & $2.82 \%$ & Algeria & 10.86 & $4.61 \%$ \\
Turkey & 5.78 & $2.45 \%$ & Oman & 7.90 & $3.35 \%$ \\
Italy & 5.39 & $2.29 \%$ & Brunei & 6.89 & $2.92 \%$ \\
\hline
\end{tabular}

Source: IEA “World - Natural gas statistics," IEA Natural Gas Information Statistics (database), 2013, doi: 10.1787/data-00482-en.

The Asia-Pacific region is more dependent on LNG imports to meet natural gas demand than are other regions. The region meets 36 per cent of its aggregate natural gas demand through LNG imports. However, within the region there are significant differences in the dependence on LNG imports.

\footnotetext{
95 Authors' calculations, based on: IEA, "World - Natural gas imports."

96 ibid.

97 ibid.

98 ibid.

99 ibid.
} 


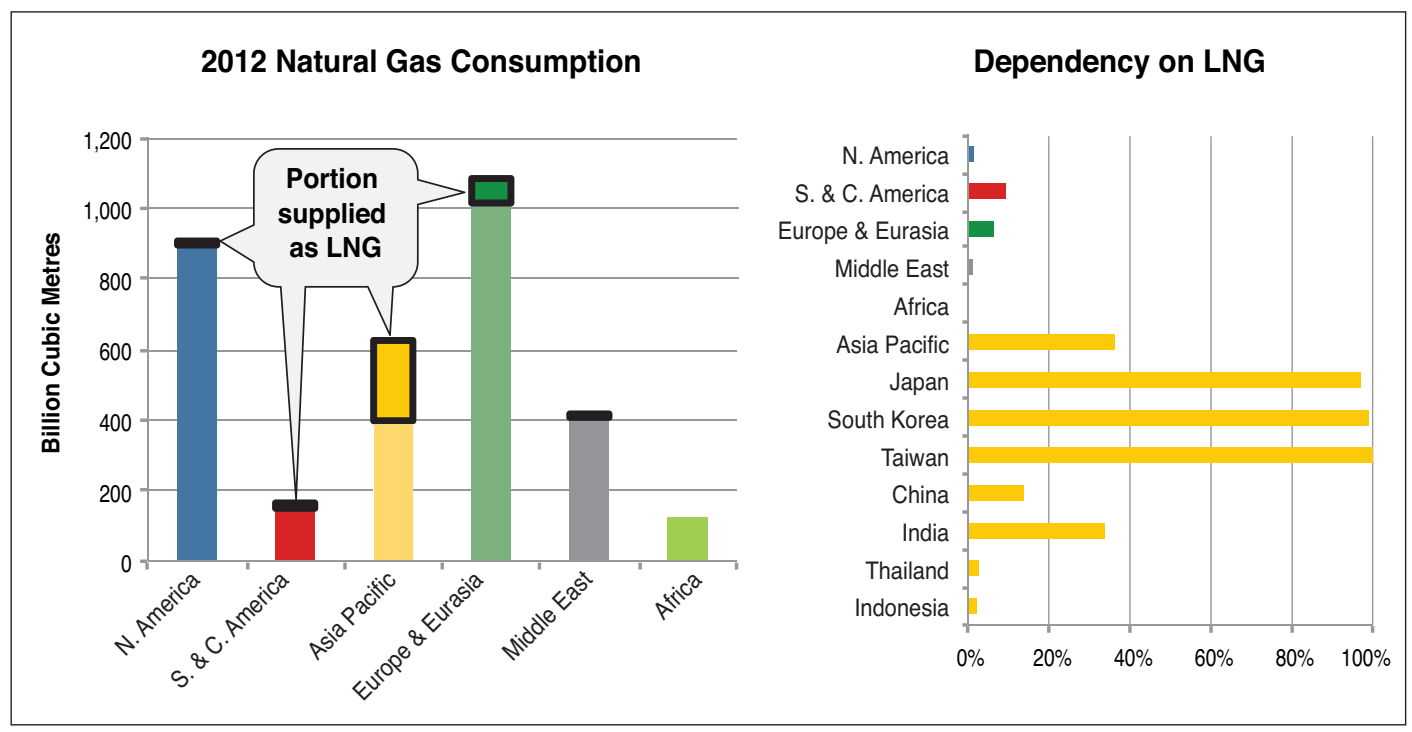

Source: BP, BP Statistical Review of World Energy June 2013 (2013).

\subsection{The Big Five: Japan, South Korea, Taiwan, China and India}

According to BP, Asia-Pacific LNG imports grew by 10 per cent from 2011 to $2012 .{ }^{100}$ Japan, South Korea, Taiwan, China and India accounted for almost all of the region's LNG demand in 2012, and imports into each of these countries grew substantially from 2010 to 2011 and from 2011 to $2012 .^{101}$

Japan, as the largest LNG-consuming country in the world, imported 89 MMT of LNG in 2012, up from 72 MMT in 2010, before the Fukushima nuclear plant crisis. Following at a distant second to Japan, South Korea imported 35 MMT during 2012. LNG imports to Taiwan, for decades the third largest importer of LNG in the region, were surpassed by imports in China in 2011 and India in 2012. Despite continued growth in LNG demand, Taiwan fell to fifth place among the region's LNG importers, with imports of 12.8 MMT in 2012.

Japan and South Korea rely almost entirely on LNG for their natural gas supply. Both Japan and South Korea have small domestic natural gas resources offshore, but gas production in both countries is negligible. Taiwan, with no natural gas resources, is 100 per cent dependent on LNG imports to meet its natural gas needs.

In 2012, China and India, two of the fastest-growing LNG markets in the world, imported 14 MMT and 12.4 MMT of LNG, respectively. China and India have significant natural gas resources and are striving to rapidly develop their domestic resources in parallel with, and in preference to, increasing natural gas imports. However, both China and India have struggled to develop their domestic resources quickly enough to meet the rapidly growing demand for natural gas. Hence, both have looked to pipeline gas and LNG imports to meet increasing demand.

\footnotetext{
${ }^{100}$ BP, BP Statistical Review (2013).

${ }^{101}$ Authors' calculations, based on: IEA, "World - Natural gas imports."
} 
In 2012, China consumed 142 BCM of natural gas, the equivalent of 104 MMT of LNG. ${ }^{102}$ China still produces the majority of the natural gas that it consumes, but its imports of natural gas are growing quickly. In 2012, China produced 107.2 BCM of natural gas, "exported" 2.85 BCM to Hong Kong, and imported 38.4 BCM, of which 50 per cent was imported through the 1,833-kilometre Turkmenistan-Uzbekistan-Kazakhstan pipeline. ${ }^{103}$ In 2012, LNG met 13 per cent of China's natural gas demand.

In 2012, India consumed 56.3 BCM of natural gas, equivalent to $41 \mathrm{MMT}$ of LNG. ${ }^{104}$ India still produces the majority of the natural gas that it consumes, but its imports of natural gas are growing quickly. In 2012, India produced 40.4 BCM of natural gas, and imported 16.9 BCM in the form of LNG. ${ }^{105}$ Although proposals to import pipeline gas from Central Asia and Bangladesh have been discussed for decades, at this time India does not import any natural gas via cross-border pipelines.

FIGURE 4.5: BIG FIVE LNG IMPORTS 2010 - 2012

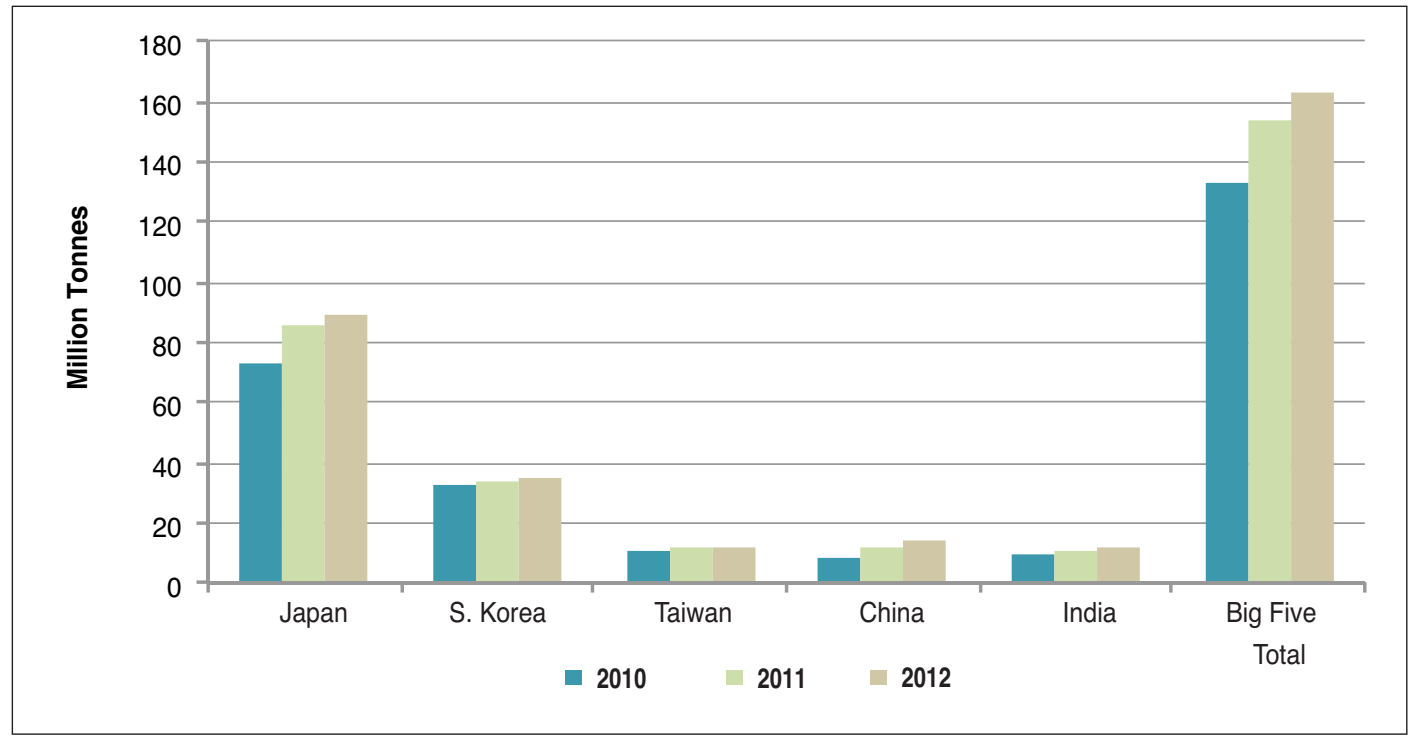

Source: IEA, "World - Natural gas imports by origin," IEA Natural Gas Information Statistics (database), 2013, doi: 10.1787/data-00482-en.

\footnotetext{
${ }^{102}$ IEA, "World - Natural gas statistics", IEA Natural Gas Information Statistics (database), 2013, doi: 10.1787/data00482-en.

103 ibid.

${ }^{104}$ ibid.

105 ibid.; and IEA, "World - Natural gas imports."
} 


\subsection{Southeast Asia}

Thailand entered the ranks of LNG buyers when it took delivery of its first LNG cargo from Qatar in 2011. It was the first country in Southeast Asia to import LNG. In 2012, Thailand imported 1 MMT of LNG in spot and short-term purchases from Yemen, Peru, Qatar, Nigeria, and Trinidad and Tobago. ${ }^{106}$ Thailand was unable to agree on the terms for long-term LNG purchases with an LNG supplier until December 2012, when it executed an agreement with Qatar. Under the terms of the agreement, Qatar will deliver 2 MMTPA to Thailand starting in 2015. ${ }^{107}$

In 2012, Thailand consumed 43.1 BCM of natural gas, the equivalent of 31.6 MMT of LNG. ${ }^{108}$ Most of the natural gas was supplied by domestic producing fields in the Gulf of Thailand (31.3 BCM) and pipeline gas imports from Myanmar $(9.7 \mathrm{BCM}) .{ }^{109}$ Just over three per cent of the natural gas consumed came from LNG imports. According to the U.S. EIA, Thailand's Energy Ministry expects natural gas production to peak in 2017 and to be depleted by 2030 at current production levels. ${ }^{110}$ In the absence of new discoveries, Thailand will need to import increasing volumes of LNG to supplement and replace depleting domestic gas resources in the Gulf of Thailand and pipeline gas imports from Myanmar. Thailand's LNG imports can be expected to grow steadily to a substantial level.

In addition, Indonesia, Singapore, and Malaysia commissioned LNG import terminals, which can now take delivery of LNG. A floating storage and regasification unit (FSRU) import terminal was commissioned offshore West Java, Indonesia in mid-2012. ${ }^{111}$ Indonesia can import LNG, or can ship LNG from three Indonesian LNG export plants (in East Kalimantan and Papua provinces) to the West Java terminal in Western Indonesia. In 2012, 0.7 MMT of LNG was delivered from the Bontang LNG plant in East Kalimantan (Borneo) to West Java. ${ }^{112}$ In 2013, Indonesia signed its first import contract with Cheniere Energy for imports from the U.S., with delivery starting in $2018 .^{113}$

Indonesia has been an LNG exporter for four decades. However, increasing domestic demand for natural gas, combined with a decline in natural gas production feeding its liquefaction plants at Arun and Bontang, led to speculation that Indonesia might become a net importer of LNG before the end of the decade. Plans are in place to convert the Arun liquefaction facility in Sumatra to an import terminal to supply the domestic market in Aceh province. ${ }^{114}$

\footnotetext{
${ }^{106}$ GIIGNL, The LNG Industry in 2012.

${ }^{107}$ Qatargas, "Qatargas 3 signs long-term agreement with PTT of Thailand," press release, December 12, 2012, http://www.qatargas.com/English/MediaCenter/PressReleases/2012/Pages/12DecSPAwithPTT-PR.aspx.

${ }^{108}$ IEA, "World - Natural gas statistics."

${ }^{109}$ ibid.; and IEA, "World - Natural gas imports."

${ }^{110}$ EIA website, "Thailand," http://www.eia.gov/countries/analysisbriefs/Thailand/thailand.pdf.

${ }^{111}$ GIIGNL, The LNG Industry in 2012.

112 ibid.

${ }^{113}$ EIA website, “Indonesia," http://www.eia.gov/countries/cab.cfm?fips=id.

114 ibid.
} 
In 2013, Singapore took the first delivery of LNG under a long-term agreement to purchase 3 MMTPA of LNG from BG Group's LNG supply portfolio. ${ }^{115}$ Singapore will import LNG to supplement and replace its pipeline gas supplies, assuage concerns about the long-term security of pipeline gas imports from neighbouring countries, and to help establish Singapore as a regional natural gas trading hub.

In 2012, Singapore consumed 9.4 BCM of natural gas. ${ }^{116}$ Singapore met its natural gas requirements through pipeline gas imports from Malaysia (18 per cent) and Indonesia (82 per cent). ${ }^{117}$

Although Malaysia did not import LNG in 2012, it can now ship LNG within Malaysian territory, from LNG export plants in Sarawak to an import terminal in peninsular Malaysia, or import LNG from other countries.

\subsection{The West Coast of the Americas}

The west coasts of Mexico and Chile are on the eastern rim of the Pacific Basin. The Energia Costa Azul import terminal on Mexico's west coast started commercial operations in 2008, with the intent of importing LNG from Indonesia (Tangguh) and Russia (Sakhalin) to supply Northern Mexico and Southern California. However, as the cost of natural gas supplies in the U.S. fell, the LNG sellers exercised options to divert LNG supplies from Costa Azul to higherpriced markets in North Asia. In 2012, Costa Azul took delivery of only 0.2 MMT of LNG from Indonesia. Manzanillo, the second LNG import terminal on Mexico's west coast, was placed into service in 2012.

Chile has two operating LNG import terminals and a third under construction with an expected startup date in 2014. Chile imported 3 MMT of LNG in 2012, supplied from Trinidad (2.3 MMT), Equatorial Guinea (0.3 MMT), Yemen (0.2 MMT), Egypt (0.1 MMT), and Norway (0.1 MMT).

Costa Azul is a candidate for conversion from an import to an export terminal, as it is connected to the U.S.-Mexico pipeline grid and could feasibly be supplied by U.S. pipeline gas. The other liquefaction facilities are not connected via pipeline to U.S. supplies, and are not candidates for conversion.

\footnotetext{
${ }^{115}$ BG Group website, “Singapore,” http://www.bg-group.com/252/where-we-work/singapore/.

${ }^{116}$ IEA, "World - Natural gas statistics."

${ }^{117}$ IEA, "World - Natural gas imports."
} 


\section{DETAILED COMPETITION FROM WORLD SOURCES}

While demand for natural gas has been growing throughout the Pacific Basin in recent years, regional suppliers have been able to match that demand in the face of the attractive price differentials available. New production in the U.S. (in excess of domestic demand) has the potential to compete in terms of new supply and to capture a larger share of the market. This opportunity highlights the potential for new, cost-effective supplies from Canada, given its distance advantage relative to the U.S. Gulf Coast.

Within the Asia-Pacific region, Australian LNG export capacity has increased and will more than triple, from 24 MMTPA today to 85.8 MMTPA by 2017-18 based on current construction. ${ }^{118}$ In Table 5.1 we illustrate the growth of LNG supply by country, excluding Canada, that supplies or might logically supply Asia-Pacific countries. As can be seen, the number of countries that have LNG liquefaction plants and their aggregate capacity has grown significantly.

TABLE 5.1: GROWTH OF LNG SUPPLY CAPACITY OF SELECTED COUNTRIES

\begin{tabular}{|c|c|c|c|c|c|c|c|c|c|c|}
\hline & \multicolumn{2}{|c|}{1990} & \multicolumn{2}{|c|}{2000} & \multicolumn{2}{|c|}{2005} & \multicolumn{2}{|c|}{2010} & \multicolumn{2}{|c|}{ 2015/6 (projected) } \\
\hline Country & $\begin{array}{l}\text { Export } \\
\text { Sites }\end{array}$ & MMTPA & $\begin{array}{c}\text { Export } \\
\text { Sites }\end{array}$ & MMTPA & $\begin{array}{l}\text { Export } \\
\text { Sites }\end{array}$ & MMTPA & $\begin{array}{l}\text { Export } \\
\text { Sites }\end{array}$ & MMTPA & $\begin{array}{l}\text { Export } \\
\text { Sites }\end{array}$ & MMTPA \\
\hline U.S. (Alaska) & 1 & 1.5 & 1 & 1.5 & 1 & 1.5 & 1 & 1.5 & 1 & 1.5 \\
\hline U.S. Gulf Coast & - & - & - & - & - & - & - & - & 1 & 9 \\
\hline Peru & - & - & - & - & - & - & 1 & 4.45 & 1 & 4.45 \\
\hline Australia & 1 & 4.4 & 1 & 6.6 & 1 & 11 & 2 & 19.7 & 9 & 82.2 \\
\hline Indonesia & 2 & 22.28 & 2 & 33.71 & 2 & 33.71 & 3 & 41.31 & 4 & 37.73 \\
\hline Malaysia & 1 & 8.1 & 1 & 15.9 & 1 & 22.7 & 1 & 24.2 & 2 & 29 \\
\hline Brunei & 1 & 7.1 & 1 & 7.1 & 1 & 7.1 & 1 & 7.1 & 1 & 7.1 \\
\hline Papua New Guinea & - & - & - & - & - & - & - & - & 1 & 6.9 \\
\hline Russia & - & - & - & - & - & - & 1 & 9.55 & 1 & 9.55 \\
\hline Qatar & - & - & 2 & 12.6 & 2 & 26 & 2 & 69.7 & 2 & 69.7 \\
\hline U.A.E. & 1 & 5.8 & 1 & 5.8 & 1 & 5.8 & 1 & 5.8 & 1 & 5.8 \\
\hline Oman & - & - & 1 & 6.7 & 1 & 6.7 & 1 & 10.4 & 1 & 10.4 \\
\hline Yemen & - & - & - & - & - & - & 1 & 6.7 & 1 & 6.7 \\
\hline Equatorial Guinea & & & & & & & 1 & 3.7 & 1 & 3.7 \\
\hline Total & 7 & 49.18 & 10 & 89.91 & 10 & 114.51 & 16 & 204.11 & 27 & 283.73 \\
\hline World Total & 10 & 74.48 & 15 & 124.61 & 18 & 177.96 & 29 & 280.36 & 42 & 366.61 \\
\hline
\end{tabular}

Notes: "Projected" is based on liquefaction terminals currently under construction. Oman/Qalhut LNG has three trains, with two owned by Oman LNG and one owned by Oalhut LNG, although they are part of the same facility. Projected capacity for Indonesia includes capacity subtractions due to conversions to regasification. Supply from Alaska stopped between October 2012 and April 2014, and is not likely to last past 2016, as noted below in Section 5.1.1.

Source: See Appendix E.

Global trade in LNG has grown dramatically since 2000 as demand for natural gas has grown in countries without sufficient native gas resources, and worldwide LNG export capacity has increased to meet the demand. From 2000 to 2011, LNG trade grew by 134 per cent, an average growth rate of eight per cent per year. ${ }^{119}$

\footnotetext{
${ }^{118}$ Authors' calculations. See Section 5.2.2 for details on Australia's terminals, and Appendix E for detailed data sources.

${ }^{119}$ Authors' calculations, based on: IEA, "World - Natural gas imports."
} 
In the early 1990s, Southeast Asia (Brunei, Indonesia and Malaysia) and Australia were the primary suppliers of LNG to the Asia-Pacific region. By the late 1990s, Qatar entered the market as an LNG supplier and has grown to become the largest supplier to the Asia-Pacific region. Since 1993, Australia has been a consistent supplier to the region (providing, on average, 12 per cent of imports ${ }^{120}$ and is forecast to overtake Qatar as the top exporter of LNG worldwide. This impressive growth is noted by PFC energy: ${ }^{12 I}$

"LNG trade has not only grown in volume, but in geographic reach as well. In 2006, only 13 countries exported LNG... Another five countries have since brought liquefaction capacity on-stream... Further, seven countries have expanded existing liquefaction capacity... and five countries have reexported LNG during this period."

Figure 5.1 illustrates potential growth in world liquefaction capacity. If all currently proposed and announced projects go forward, and no current capacity is mothballed, liquefaction capacity could reach 777 MMT. There are an additional 14 liquefaction projects without projected in-service dates that have a combined capacity of $127.45 \mathrm{MMT}{ }^{122}$ However, not all announced or even proposed projects will necessarily go forward; both PFC Energy ${ }^{123}$ and Goldman Sachs ${ }^{124}$ predict around 500 MMT by 2025 .

\section{FIGURE 5.1: FORECAST WORLD LIQUEFACTION CAPACITY}

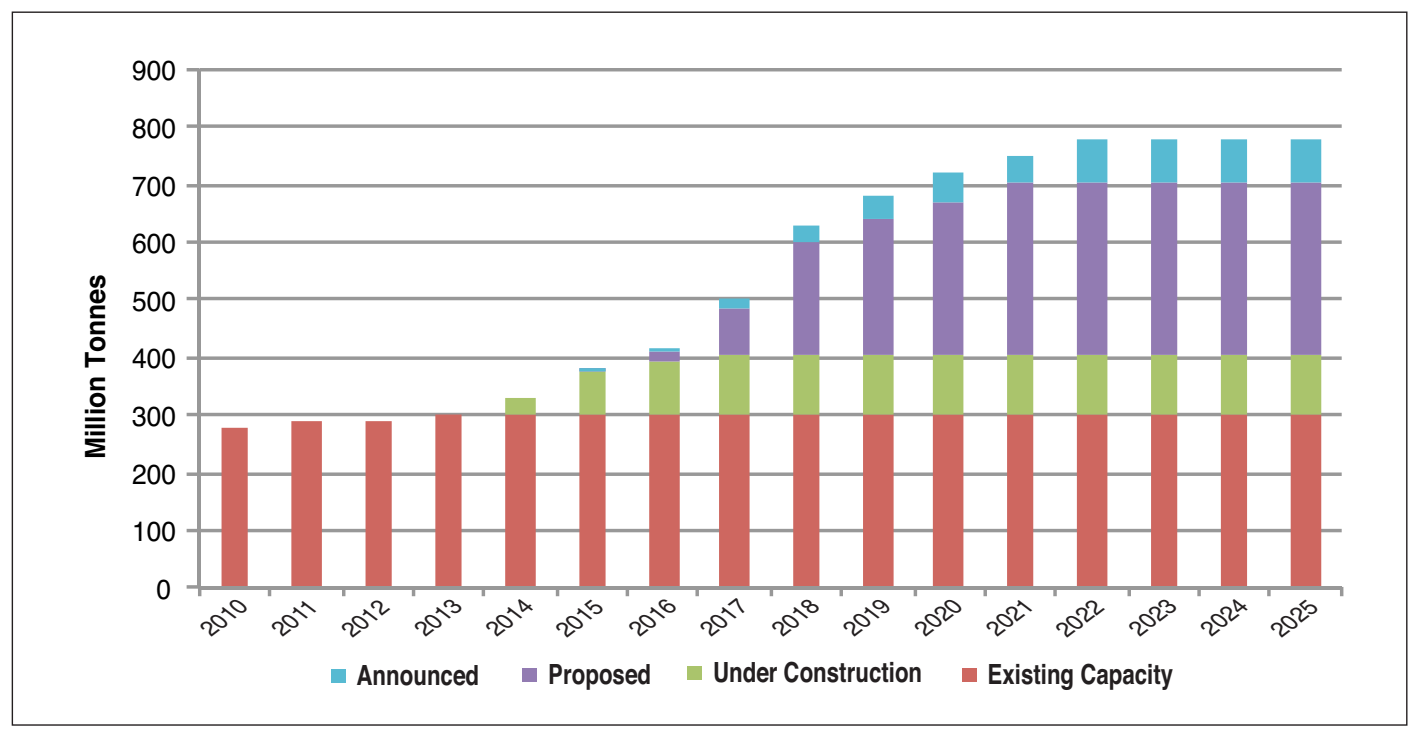

Notes: "Proposed" LNG projects are those where a source was available for cost, capacity and start year, while "announced" are projects where a source was available for start year and capacity, and where there is no evidence of cancellation. Projects without a start year or capacity are excluded from the figure.

Source: Authors' calculations based on various sources. See Appendix E for sources.

\footnotetext{
${ }^{120}$ Author's calculations; ibid.

${ }^{121}$ PFC Energy, "Global LNG," 43.

${ }^{122}$ Various sources; see Appendix E (data sources).

${ }^{123}$ PFC Energy, "Global LNG."

${ }^{124}$ Goldman Sachs, "Global LNG Update: Asian LNG Outlook Remains Strong; Pursuit of Lower Prices Remains Challenging," September 23, 2013.
} 
The Asia-Pacific countries lacking indigenous natural gas resources or without import-pipeline supply opportunities are the logical markets for LNG exported from coastal British Columbia. LNG from British Columbia will face competition from those countries that are highly dependent on sales to the Asia-Pacific market. Table 5.2 illustrates the 2012 world LNG trade patterns, sorted for the top suppliers to the Asia-Pacific, where the Asia-Pacific region represents almost 70 per cent of world export volumes. ${ }^{125}$ The rightmost column shows exports to the Asia-Pacific as a percentage of total exports from each exporting country. This highlights the dependence of many LNG exporters on the Asia-Pacific market and those that are likely direct market competitors with LNG from Canada.

As noted earlier, the increase in liquefaction capacity in the near term is limited, except for in Australia and the U.S. The next sections review liquefaction activities outside of Canada by region.

TABLE 5.2: LNG TRADE MOVEMENTS 2012 (BCM)

\begin{tabular}{|c|c|c|c|c|c|c|c|c|c|c|c|c|c|}
\hline & \begin{tabular}{|c|} 
North \\
America
\end{tabular} & $\begin{array}{c}\text { South \& } \\
\text { Central } \\
\text { America }\end{array}$ & $\begin{array}{l}\text { Europe } \\
\text { and } \\
\text { Eurasia }\end{array}$ & $\begin{array}{c}\text { Middle } \\
\text { East }\end{array}$ & China & India & Japan & $\begin{array}{l}\text { South } \\
\text { Korea }\end{array}$ & Taiwan & Thailand & $\begin{array}{c}\text { Asia } \\
\text { Pacific }\end{array}$ & \begin{tabular}{|l|} 
Total \\
exports
\end{tabular} & \begin{tabular}{|c|} 
Asia \\
Pacific \\
as $\%$ \\
of Total \\
Exports
\end{tabular} \\
\hline Qatar & 3.6 & 1.3 & 31.1 & 2.9 & 6.8 & 16.1 & 21.3 & 14.2 & 7.9 & 0.3 & 66.5 & 105.4 & $63 \%$ \\
\hline Malaysia & - & - & - & - & 2.5 & - & 19.9 & 5.6 & 3.8 & - & 31.8 & 31.8 & $100 \%$ \\
\hline Australia & - & - & - & 0.1 & 4.8 & - & 21.6 & 1.1 & 0.3 & - & 28.0 & 28.1 & $100 \%$ \\
\hline Indonesia & 0.3 & - & - & - & 3.3 & 0.2 & 8.4 & 10.3 & 2.6 & - & 24.7 & 25.0 & $99 \%$ \\
\hline $\begin{array}{l}\text { Russian } \\
\text { Federation }\end{array}$ & - & - & - & - & 0.5 & - & 11.3 & 3.0 & - & - & 14.8 & 14.8 & $100 \%$ \\
\hline Nigeria & 1.1 & 0.5 & 11.6 & 0.8 & 0.4 & 2.1 & 6.5 & 2.5 & 1.6 & 0.1 & 13.1 & 27.2 & $48 \%$ \\
\hline Oman & - & - & - & - & 0.1 & - & 5.4 & 5.7 & - & - & 11.2 & 11.2 & $100 \%$ \\
\hline Brunei & - & - & - & - & - & - & 8.0 & 1.1 & - & - & 9.1 & 9.1 & $100 \%$ \\
\hline $\begin{array}{l}\text { United Arab } \\
\text { Emirates }\end{array}$ & - & - & - & 0.1 & - & - & 7.5 & - & - & - & 7.5 & 7.6 & $99 \%$ \\
\hline Yemen & 0.9 & 0.3 & - & - & 0.8 & 0.6 & 0.4 & 3.6 & - & 0.5 & 5.9 & 7.1 & $82 \%$ \\
\hline $\begin{array}{l}\text { Equatorial } \\
\text { Guinea }\end{array}$ & - & 0.4 & 0.1 & - & - & - & 3.8 & 0.5 & 0.2 & - & 4.5 & 4.9 & $91 \%$ \\
\hline Egypt & 0.1 & 0.3 & 2.4 & 0.2 & 0.4 & 0.8 & 1.4 & 0.8 & 0.3 & - & 3.8 & 6.7 & $56 \%$ \\
\hline $\begin{array}{l}\text { Trinidad \& } \\
\text { Tobago }\end{array}$ & 4.2 & 10.1 & 2.6 & 0.4 & 0.2 & - & 0.4 & 1.1 & 0.1 & 0.1 & 1.9 & 19.1 & $10 \%$ \\
\hline Peru & 1.2 & - & 2.6 & - & - & - & 1.1 & - & - & 0.4 & 1.5 & 5.4 & $29 \%$ \\
\hline Other Europe & - & 1.1 & 1.1 & - & - & 0.2 & 0.5 & 0.2 & 0.1 & - & 0.9 & 3.2 & $27 \%$ \\
\hline Algeria & - & - & 14.4 & - & 0.1 & 0.6 & 0.2 & - & - & - & 0.9 & 15.3 & $6 \%$ \\
\hline Norway & 0.2 & 0.6 & 3.1 & 0.2 & - & - & 0.6 & 0.1 & 0.1 & - & 0.7 & 4.7 & $15 \%$ \\
\hline U.S. & 0.0 & 0.2 & 0.1 & - & - & 0.1 & 0.4 & - & - & - & 0.5 & 0.8 & $61 \%$ \\
\hline Brazil & - & 0.4 & - & - & & - & 0. & - & - & - & 0.1 & 0.4 & $16 \%$ \\
\hline Total imports & 11.6 & 15.2 & 69.3 & 4.6 & 20.0 & 20.5 & 118.8 & 49.7 & 16.9 & 1.4 & 227.2 & 327.9 & $69 \%$ \\
\hline
\end{tabular}

Note: Export volumes from U.S. and Other Europe include re-exports.

Source: BP, BP Statistical Review of World Energy June 2013 (2013).

\footnotetext{
${ }^{125}$ Data is sourced from: BP, Statistical Review of World Energy June 2012 (2012), http://www.bp.com/content/dam/bp/pdf/Statistical-Review-2012/statistical_review_of_world_energy_2012.pdf.
} 


\subsection{Eastern Pacific}

The Eastern Pacific, including the U.S. Gulf Coast and East Coast, has had limited LNG liquefaction capacity. This picture is changing.

\subsubsection{ALASKA}

Alaska is home to the second-oldest commercial liquefaction plant in the world. The Kenai LNG plant in Alaska was put on standby in October 2012, and its export licence expired in 2013. A new licence was issued April 14, 2014, which grants licence to export 1.13 BCM (40 $\mathrm{BCF}$ ) of LNG over two years. ${ }^{126}$ The suspension was to preserve natural gas for domestic use as Cook Inlet reserves were depleted, until new discoveries allowed for a resumption of exports. ${ }^{127}$ Without additional discoveries, it is uncertain whether Alaska will continue to export beyond 2016.

Alaska's North Slope has large gas reserves. ${ }^{128}$ Development of these reserves has been analyzed numerous times, including to assess the case for piping gas to the Lower 48 states (the historic Alaska gas pipeline project) and, more recently, piping to South-central Alaska to convert to LNG. ${ }^{22}$ The state of Alaska has a major incentive to develop the North Slope reserves, and numerous proposals and methods have been proposed, including gas-to-liquids (GTL) technology, large- and small-scale LNG, pipeline to the Lower 48 and development for in-state use. To date, none of these ideas have come to fruition, primarily because of the high cost of implementation.

Recently, the State of Alaska joined a consortium including ExxonMobil, BP, ConocoPhillips and TransCanada Corp., in a project to export LNG. ${ }^{130}$ This project is estimated to cost between $\$ 45$ and $\$ 65$ billion and includes gas processing on the North Slope and a 1,287kilometre gas pipeline and liquefaction plant on the Kenai Peninsula, with shipments projected to begin in $2021 .^{131}$ The State of Alaska agreed to take as much as a 25 per cent stake in the project to help expedite its development. ${ }^{132}$

\subsubsection{U.S. LOWER 48}

Historically, the U.S. has been an LNG importer and there are no operating LNG export plants in the U.S. Lower 48. This is changing as the revolution in shale- and tight-gas production has

\footnotetext{
${ }^{126}$ ConocoPhillips website, "Kenai LNG Exports," http://alaska.conocophillips.com/what-we-do/naturalgas/lng/Pages/kenai-lng-exports.aspx.

${ }^{127}$ Tim Bradner, "First LNG ship since 2012 arrives at ConocoPhillips plant near Kenai," Alaska Journal of Commerce, May 2, 2014, http://www.alaskajournal.com/Alaska-Journal-of-Commerce/Breaking-News-2013/First-LNG-shipsince-2012-arrives-at-ConocoPhillips-plant-near-Kenai/.

${ }^{128}$ According to the U.S. Geological Survey's National Oil and Gas Assessment, the Central North Slope has 37.5 TCF of gas (assessed in 2005), the entire North Slope has 18 TCF of coal-bed gas (assessed 2006) and 40.6 TCF of shale gas (assessed 2012). U.S. Geological Survey website, "National Oil and Gas Assessment," http://energy.usgs.gov/OilGas/AssessmentsData/NationalOilGasAssessment.aspx\#.U1gAbvldXmc.

${ }^{129}$ Alaska Pipeline Project website, “Commercial Information,” http://thealaskapipelineproject.com/commercial.

${ }^{130}$ Bradley Olson and Rebecca Penty, “Alaska to Pay \$5.75 Billion for Exxon LNG Project Stake,” Bloomberg, January 15, 2014, http://www.bloomberg.com/news/2014-01-15/alaska-to-pay-5-75-billion-for-exxon-lng-export-project-stake.html.

131 ibid.

${ }^{132}$ ibid.
} 
dramatically increased gas-supply potential. The U.S. has the opportunity to add gas liquefaction equipment to idle LNG import infrastructure to convert these sites for LNG export. The equipment existing with the LNG import terminals, jetty, tanks, infrastructure, and pipeline connections, significantly reduces the investment required for converting plants to liquefaction. Based on analysis of brownfield- and greenfield-project cost estimates on the U.S. Gulf Coast, a greenfield project costs about one-third more than a brownfield project. ${ }^{133}$

While not technically in the Pacific Basin, U.S. Gulf Coast projects have access to the Pacific Ocean through the Panama Canal. A number of plants are planned for the U.S.; all but three are on the U.S. Gulf Coast. One Gulf Coast plant, Cheniere at Sabine Pass, is under construction, with an estimated in-service date of the fourth quarter of 2015. ${ }^{134}$ The first two trains of the plant will have a capacity of 9.0 MMTPA. The three proposed plants not on the Gulf Coast are at: Cove Point in Maryland (5.25 MMTPA); ${ }^{135}$ Oregon LNG (9.9 MMTPA) ${ }^{136}$ at Warrenton, Ore.; and Jordon Cove (6 MMTPA) $)^{137}$ in Coos Bay, Ore. The Oregon projects plan to use gas supplied from Canada and have applied for and received Canadian export permits for long-term supply. ${ }^{138}$

TABLE 5.3: POTENTIAL U.S. LOWER 48 LNG EXPORT PROJECTS

\begin{tabular}{|l|l|r|r|l|l|}
\hline Location & \multicolumn{1}{|c|}{ Name } & $\begin{array}{c}\text { Completion } \\
\text { Year }\end{array}$ & \multicolumn{1}{|c|}{$\begin{array}{c}\text { MM } \\
\text { TPA }\end{array}$} & \multicolumn{1}{|c|}{ Status } & Notes \\
\hline Louisiana & Sabine Pass T1-T2 & 2015 & 9 & Under construction & Conversion from regas \\
Louisiana & Sabine Pass T3-4 & 2017 & 9 & Under construction & Conversion from regas \\
Maryland & Cove Point LNG & 2017 & 5.25 & Proposed & Conversion from regas \\
Gulf of Mexico & Main Pass Energy Hub & 2017 & 24 & Proposed & Floating LNG \\
Texas & Corpus Christi LNG & 2018 & 13.5 & Proposed & \\
Georgia & Elba Island LNG Phase 1 \& 2 & 2018 & 2.5 & Proposed & Conversion from regas \\
Texas & Freeport Expansion & 2018 & 14.2 & Proposed & Existing regas plant, addition \\
& Golden Pass & 2018 & 15.6 & Proposed & \\
Texas & Jordan Cove - Coos Bay & 2018 & 6 & Proposed & \\
Oregon & Magnolia LNG T1-2 & 2018 & 4 & Proposed & \\
Louisiana & Cameron LNG & 2019 & 12 & Proposed & Conversion from regas \\
Louisiana & Lake Charles Expansion & 2019 & 15 & Proposed & Conversion from regas \\
Louisiana & (Trunkline LNG) & 2019 & 9.9 & Proposed & \\
Oregon & Oregon LNG & 2018 & 8 & Announced & \\
Texas & South Texas LNG T1-2 & 2019 & 1.5 & Announced & \\
Louisiana & Gasfin LNG & 2018 & 5 & Announced & \\
Louisiana & Venture Global LNG & 2018 & 2 & Announced & \\
Texas & Gulf Coast LNG T1-4 & Texas LNG & & & \\
Texas & & & & \\
\hline
\end{tabular}

Source: See Appendix E for details. "Proposed" LNG projects are those where a source was available for cost, capacity and start year, while "announced" are projects where a source was available for start year and capacity, and where there is no evidence of cancellation.

\footnotetext{
${ }^{133}$ Stillwater Associates LLC analysis.

${ }^{134}$ Cheniere Energy website, "Sabine Pass Liquefaction Project," http://www.cheniere.com/lng_industry/sabine_pass_liquefaction.shtml.

${ }^{135}$ Dominion Resources Inc. website, “Dominion Cove Point,” https:/www.dom.com/business/gas-transmission/cove-point/.

${ }^{136}$ Oregon LNG website, "Terminal," http://www.oregonlng.com/terminal/.

${ }^{137}$ Jordan Cove Energy Project LP website, "Project Overview," http://www.jordancoveenergy.com/project.htm.

${ }^{138}$ National Energy Board website, "LNG Export License Applications," http://www.neb-one.gc.ca/clfnsi/rthnb/pplctnsbfrthnb/lngxprtlcncpplctns/lngxprtlcncpplctns-eng.html.
} 
The current Panama Canal has limits that restrict the size of LNG carriers that can use this shorter route to the Pacific Basin from the Gulf Coast. In 2015, the expanded Panama Canal will allow all but the largest LNG carriers to traverse the canal. The expansion will improve the economics for the U.S. Gulf Coast LNG facilities to supply the Pacific Basin, provided the canal tolls are less than the costs (in time and operation) for shipping around Cape Horn or Tierra del Fuego. Another consideration is that U.S. East Coast and Gulf Coast projects can more logically supply Europe, which would have the effect of freeing up cargoes from the Middle East that supply Europe, which could then be diverted to Asia.

\subsubsection{CENTRAL AND SOUTH AMERICA}

There are two LNG facilities in this region. One is in Trinidad and Tobago, with a capacity of 14.8 MMTPA, that originally began operations in $1999 .{ }^{139}$ It was expanded from the original 3 MMTPA in 2002, 2003 and 2005. The other facility is on the coast of Peru. Started up in 2010, the plant has a capacity of 4.4 MMTPA. There is one new small project planned for the area, a 0.55 -MMTPA barge-mounted facility in Colombia. ${ }^{140}$ LNG facilities were also planned for Venezuela, however, the government decided to reserve the gas for domestic use. ${ }^{141}$ It is anticipated that there will be little change in LNG export activity in Central and South America.

\subsection{Western Pacific}

\subsubsection{SOUTHEAST ASIA}

The following table summarizes the current and under-construction LNG-liquefaction capacity in Southeast Asia.

\footnotetext{
${ }^{139}$ Atlantic LNG website, "Our Trains," http://www.atlanticlng.com/our-business/our-trains.

${ }^{140}$ Gurdip Singh, "EXMAR launches FLRSU to exploit stranded gas offshore Colombia," Offshore 1, 8 (August 2012).

${ }^{141}$ Reuters, "UPDATE 3-Venezuela freezes LNG projects, eyes local demand," September 28, 2011, http://www.reuters.com/article/2011/09/28/venezuela-gas-idUSS1E78R0UG20110928.
} 
TABLE 5.4: SOUTHEAST ASIA LNG EXPORT PROJECTS

\begin{tabular}{|c|c|c|c|c|c|}
\hline Location & Name & $\begin{array}{c}\text { Completion } \\
\text { Year }\end{array}$ & $\begin{array}{l}\text { MM } \\
\text { TPA }\end{array}$ & Status & Notes \\
\hline Brunei & Lumut & 1973 & 7.10 & Operating & \\
\hline Indonesia & Bontang & 1977 & 19.63 & Operating & $\begin{array}{l}\text { Original size: } 4.5 \text { MMTPA; } \\
\text { expansions occurred in 1983, } \\
1989,1993 \text { and } 1996\end{array}$ \\
\hline Indonesia & Arun & 1978 & 14.08 & Operating & $\begin{array}{l}\text { Converting to imports. Original } \\
\text { size: } 3.4 \text { MMTPA; expansions } \\
\text { occurred in 1979, 1981, } \\
\text { 1983, } 1984,1986 \text { and } 1993\end{array}$ \\
\hline Malaysia & Bintulu & 1983 & 24.20 & Operating & $\begin{array}{l}\text { Original size: } 8.1 \text { MMTPA; } \\
\text { expansions occurred in 1995, } \\
2003 \text { and } 2010\end{array}$ \\
\hline Indonesia & Tangguh & 2009 & 7.60 & Operating & \\
\hline Indonesia & Donggi Senoro & 2014 & 2.00 & Under construction & \\
\hline Indonesia & SengKang LNG & 2014 & 2.00 & Under construction & \\
\hline $\begin{array}{l}\text { Papua } \\
\text { New Guinea }\end{array}$ & PNG LNG T1-T2 & 2014 & 6.90 & Under construction & \\
\hline Malaysia & MLNG Mini-Expansion & 2014 & 0.70 & Under construction & Expansion \\
\hline Malaysia & Petronas FLNG 1 & 2015 & 1.20 & Under construction & Floating Unit \\
\hline Malaysia & Petronas LNG 9 (Bintulu) & 2015 & 3.60 & Under construction & Expansion \\
\hline Brunei & Lumut Expansion & 2015 & 4.00 & Announced & Expansion \\
\hline $\begin{array}{l}\text { Papua } \\
\text { New Guinea }\end{array}$ & InterOil Gulf LNG & 2016 & 8.00 & Proposed & \\
\hline Malaysia & Petronas FLNG 2 & 2018 & 1.50 & Announced & Floating Unit \\
\hline Indonesia & Abadi FLNG & 2019 & 2.50 & Proposed & Floating Unit \\
\hline
\end{tabular}

Source: See Appendix E for details. "Proposed" LNG projects are those where a source was available for cost, capacity and start year, while "announced" are projects where a source was available for start year and capacity, and where there is no evidence of cancellation.

\subsubsection{Indonesia}

Indonesia was a pioneer in LNG exports, opening the Arun LNG plant in $1978 .{ }^{142}$ Currently, Indonesia has three operating LNG export facilities with a combined capacity of 41.3 MMTPA. However, 14 MMTPA of this capacity is at Arun, and Pertamina, the owner of the facility, is looking to convert Arun into an import terminal. ${ }^{143}$ The LNG facility at Bontang, which began exporting in 1977, may be a candidate for idling if gas reserves dwindle. The Tangguh LNG facility is of more recent vintage, having started up in 2009. In Sulawesi, the 2.0 MMTPA Donggi-Senoro and 2.0 MMTPA Sengkang LNG plants are under construction, and expected to be completed in 2014. An additional floating LNG facility, Abadi FLNG, with capacity of 2.5 MMTPA, has been proposed, with a projected start year of $2019 .{ }^{144}$

\footnotetext{
${ }^{142}$ PT Arun NGL website, “Our Profile,” http://www.arunlng.co.id/profile.php.

${ }^{143}$ Pertamina, "Repositioning Arun LNG Plant - 1st Time in LNG History, From Liquefaction Become Ragasification Terminal," presentation by Daniel Purba at LNG 17 conference, April 16, 2013, http://www.gastechnology.org/Training/Documents/LNG17-proceedings/03_05-Daniel-Purba-Presentation.pdf.

144 “Inpex delays Indonesia Abadi LNG project startup to 2019 - media,” London South East, June 25, 2013, http://www.lse.co.uk/FinanceNews.asp?code=kvkqidfa\&headline=Inpex_delays_Indonesia_Abadi_LNG_project_star tup_to_2019_media.
} 


\subsubsection{Malaysia}

Malaysia was the third country in the region to become an LNG exporter when the first train was opened at the Bintulu LNG facility in 1983. There are three plants, owned and operated by Petronas's three joint-venture companies. ${ }^{145}$ The capacity at this site was expanded in 1995 , 2003 and 2010. Total LNG capacity at the Bintulu site is 24.2 MMTPA. ${ }^{146}$ An expansion is planned at the Bintulu site with a ninth LNG train. The train is expected to have a capacity of 3.6 MMTPA and to start up in $2015 .{ }^{147}$ An additional floating project is planned by Petronas with a capacity of 1.2 MMTPA, and is expected to be the world's first operational floating LNG project when it is completed in $2015 .^{148}$

\subsubsection{Others}

The Brunei LNG plant has a capacity of 7.1 MMTPA and was started up in 1972. The facility was renovated in 1993, and Japanese buyers extended their contracts for another 20 years. ${ }^{149} \mathrm{~A}$ Heads of Agreement was reached in 2012 for an additional 10-year term at about half the volume. ${ }^{150}$ Papua New Guinea will become an LNG exporter in 2014 when the 6.9 MMTPA PNG LNG facility starts up. ${ }^{151}$ A second LNG project, Gulf LNG, with capacity of 8 MMTPA, has been proposed for Papua New Guinea, with projected completion in 2016. ${ }^{152}$

\subsubsection{AUSTRALIA}

Australia is projected to have the largest global LNG export capacity by 2016 , reaching 82.2 MMTPA. Currently there are three export sites that are operational: NW Shelf, Pluto and Darwin. The combined capacity of these three sites total 24 MMTPA. There are an additional seven export sites that are reported to be under construction that total an additional 61.8 MMTPA. Five additional projects with a combined capacity of 20.9 MMTPA have been proposed. Some proposed projects have been cancelled; a 2013 article in Oil \& Gas Journal quotes Chevron officials expressing doubts as to whether an expansion of the Gorgon project will proceed, despite brownfield cost advantages ${ }^{153}$ One project - Fisherman's Landing LNG - started construction, but is currently on hold. ${ }^{154}$ There is a potential expansion for the Darwin site, but nothing further has been announced. ${ }^{155}$

${ }^{145}$ Petronas website, "Petronas LNG Complex," http://www.petronas.com.my/our-business/gaspower/lng/pages/lng_complex.aspx.

${ }^{146}$ International Gas Union, World LNG.

${ }^{147}$ Warren R. True, "Petronas lets contract for Train 9 compression, targets 2013 FID," Oil \& Gas Journal, June 7, 2012, http://www.ogj.com/articles/2012/06/petronas-lets-contract-for-train-9-compression-targets-2013-fid.html.

${ }^{148}$ Nina Rach, "Petronas' Kanowit field FLNG facility under construction," OE, August 19, 2013, http://www.oedigital.com/component/k2/item/3760-petronas-kanowit-field-flng-facility-under-construction.

${ }^{149}$ Brunei LNG website, "History and Background," http://www.bruneilng.com/about_history.htm.

${ }^{150}$ Goh De No and Bandar Seri Begawan, "Brunei signs pact with Japan's Tepco for 10-year LNG supply," The Brunei Times, March 15, 2012, http://www.bt.com.bn/news-national/2012/03/15/brunei-signs-pact-japans-tepco-10-year-lng-supply.

${ }^{151}$ Jane Wardell and James Regan, "Exxon's PNG LNG project costs balloon to \$19 billion," Reuters, November 11, 2012, http://www.reuters.com/article/2012/11/12/us-exxon-png-idUSBRE8AA0GR20121112.

${ }^{152}$ InterOil website, "Economics and Financing of Integrated Gulf LNG Project," September 2012, http://www.interoil.com/iocfiles/documents/investorrelations/presentationanddocuments/2012/LNG\%20Project\%20Up date\%20Investor\%20Presentation\%20September\%2029\%202012.pdf.

${ }^{153}$ Rick Wilkinson, "Chevron doubtful about fourth train for Gorgon LNG project," Oil \& Gas Journal, November 5, 2013, http://www.ogj.com/articles/2013/11/chevron-doubtful-about-fourth-train-for-gorgon-lng-project.html.

${ }^{154}$ James McGrath, "LNG project short of gas as big players snap up supply," The Observer, January 8, 2014, http://www.gladstoneobserver.com.au/news/project-short-of-gas-for-start-up/2133489/.

155 James Paton, “Conoco Weighs Larger Darwin LNG Amid Santos 'Disappointment,"” Bloomberg, April 14, 2011, http://www.bloomberg.com/news/2011-04-14/conocophillips-still-evaluating-expansion-of-darwin-lng-venture.html. 
The following table summarizes the current and under-construction LNG liquefaction capacity in Australia.

\section{TABLE 5.5: AUSTRALIA LNG EXPORT PROJECTS}

\begin{tabular}{|c|c|c|c|c|c|}
\hline Location & Name & $\begin{array}{l}\text { Completion } \\
\text { Year }\end{array}$ & $\begin{array}{l}\text { MM } \\
\text { TPA }\end{array}$ & Status & Notes \\
\hline Western Australia & North West Shelf (T1-5) & 1989 & 16.3 & Operating & $\begin{array}{l}\text { Expansions in 1993, } 2004 \\
\text { and } 2008\end{array}$ \\
\hline North Australia & Darwin & 2006 & 3.4 & Operating & \\
\hline Western Australia & Pluto & 2012 & 4.3 & Operating & \\
\hline Eastern Australia & Queensland Curtis (T1-T2) & 2014 & 8.5 & Under Construction & \\
\hline Eastern Australia & Australian Pacific & 2015 & 9 & Under Construction & \\
\hline Eastern Australia & Gladstone Santos & 2015 & 7.8 & Under Construction & \\
\hline Western Australia & Gorgon (T1-3) & 2015 & 15.6 & Under Construction & \\
\hline North Australia & Ichthys (T1-2) & 2016 & 8.4 & Under Construction & \\
\hline Western Australia & Wheatstone LNG T1-T2 & 2016 & 8.9 & Under Construction & \\
\hline Western Australia & Prelude FLNG & 2017 & 3.6 & Under Construction & Floating Unit \\
\hline Eastern Australia & Fisherman's Landing T1 & 2017 & 1.9 & Under Construction & $\begin{array}{l}\text { Construction on hold pending } \\
\text { project securing gas supplies }\end{array}$ \\
\hline North Australia & Sunrise - Timor Leste & 2017 & 4 & Proposed & $\begin{array}{l}\text { Floating Unit; project on hold } \\
\text { pending dispute resolution } \\
\text { between governments of } \\
\text { Australia and Timor Leste }\end{array}$ \\
\hline Eastern Australia & Arrow T1-T2 & 2018 & 8 & Proposed & \\
\hline North Australia & Bonaparte FLNG & 2019 & 2.4 & Proposed & $\begin{array}{l}\text { Floating Unit; FID scheduled } \\
\text { for } 2015\end{array}$ \\
\hline North Australia & Scarborough FLNG & 2020 & 6.5 & Proposed & $\begin{array}{l}\text { FID scheduled for } \\
2014 / 2015\end{array}$ \\
\hline Western Australia & Cash Maple & 2019 & & Announced & FID scheduled for 2015 \\
\hline
\end{tabular}

Source: See Appendix E for details. "Proposed" LNG projects are those where a source was available for cost, capacity and start year, while "announced" are projects where a source was available for start year and capacity, and where there is no evidence of cancellation.

Of note, and possibly very relevant to understanding the challenges for Canadian LNG development, are the projects in Eastern Australia. There are three projects under construction, Queensland Curtis LNG, Australian Pacific LNG and Gladstone LNG (and possibly a fourth, Arrow LNG), that are being built on Curtis Island, Gladstone. These projects will be supplied with natural gas from the interior by a long-distance pipeline to the liquefaction sites. The feed gas is from coal-seam methane reserves that require continuous development to supply the gas to the plants. On the plant site, the location is remote and requires development of infrastructure and facilities to support construction and operations. While the gas-reserve characteristics differ, two of these characteristics - long-distance pipelining and remote, undeveloped plant sites - are shared by the proposed Canadian projects. Eastern Australia LNG development may provide some learned lessons that may help guide Canadian LNG development. 


\subsection{Europe and Russia}

\subsubsection{EUROPE}

Europe's sole liquefaction facilities are in Norway, which has two operating terminals. Snohvit (Hammerfest) has an annual capacity of $4.3 \mathrm{MMT},{ }^{156}$ and Skangass has an annual capacity of $0.3 \mathrm{MMT} .{ }^{157}$ However, Norway's traditional markets have been in Europe, with only small volumes going to the Asia-Pacific, given the distance of that region's markets. ${ }^{158}$

Other European countries have occasionally re-exported LNG to the Asia-Pacific; for example, in 2013, Belgium re-exported to South Korea, France re-exported to Japan, and Spain reexported to Japan, South Korea and Taiwan. ${ }^{159}$

\subsubsection{RUSSIA}

Russia has one operational export terminal and three proposed. In Eastern Russia, the 9.6 MMTPA Sakhalin II facility started operations in 2009. ${ }^{160}$ A memorandum of understanding between Shell and Gazprom has been signed to expand the facility with a third - presumably 4.8 MMTPA - train. ${ }^{161}$

The proposed Vladivostok LNG export terminal, nestled between Japan, China, and South Korea, will have a starting capacity of 5 MMTPA (expanding to as large as 15 MMTPA afterwards), with operations beginning in $2018 .{ }^{162}$

Located on the shores of the Kara Sea in Russia's Arctic North is the proposed Yamal LNG export terminal. The Yamal project will have a starting capacity of 5.5 MMTPA from one train in 2017, and future expansions to a total capacity of 16.5 MMTPA. ${ }^{163}$ However, due to its northern location, icebreaker LNG tankers will be required to transport LNG via the Arctic Ocean.

Exxon and Rosneft have an LNG project in Northeast Russia that will have a capacity of 5 MMTPA if built. The project has begun the FEED stage. ${ }^{164}$ This project is somewhat complicated because Gazprom currently has a monopoly on export sales of Russian gas. ${ }^{165}$

\footnotetext{
${ }^{156}$ Subsea IQ website, “Snohvit," http://www.subseaiq.com/data/PrintProject.aspx?project_id=223.

${ }^{157}$ Skangass website, “About Skangass,” http://www.skangass.com/index.cfm?id=352980.

${ }^{158}$ IEA, "World - Natural Gas imports."

${ }^{159}$ GIIGNL, The LNG Industry in 2013.

${ }^{160}$ Gazprom website, "Eastern Gas Program," http://www.gazprom.com/about/production/projects/east-program/.

${ }^{161}$ 2b1st Consulting website, "Gazprom approved Shell Sakhalin-2 LNG Expansion Roadmap,” March 12, 2014, http://www.2b1 stconsulting.com/gazprom-approved-shell-sakhalin-2-lng-expansion-roadmap/.

${ }^{162}$ Gazprom website, "Vladivostok-LNG project," http://www.gazprom.com/about/production/projects/vladivostok-lng/.

163 Oil \& Gas Journal, "Yamal LNG Owners issue FID,” December 18, 2013, http://www.ogj.com/articles/2013/12/yamal-lng-owners-issue-fid.html.

${ }^{164}$ Rosneft, "Rosneft and ExxonMobil Selects Contractors for Initial Phase Engineering and Design for Russian Far East LNG Project," press release, September 27, 2013, http://www.rosneft.com/news/pressrelease/27092013.html.

${ }^{165}$ Ilya Arkhipov and Anna Shiryaevskaya, "Rosneft, Exxon Weigh \$15 Billion LNG Plant to Vie With Gazprom," Bloomberg, April 11, 2013, http://www.bloomberg.com/news/2013-04-11/rosneft-exxon-weigh-15-billion-lng-plantto-vie-with-gazprom.html.
} 


\subsection{Middle East}

The following table summarizes the current LNG liquefaction capacity in the Middle East.

TABLE 5.6: MIDDLE EAST LNG EXPORT PROJECTS

\begin{tabular}{|l|l|l|r|l|l|}
\hline Location & \multicolumn{1}{|c|}{ Name } & $\begin{array}{c}\text { Completion } \\
\text { Year }\end{array}$ & $\begin{array}{r}\text { MM } \\
\text { TPA }\end{array}$ & \multicolumn{1}{|c|}{ Status } & Notes \\
\hline Libya (stopped) & Marsa-el- Brega & 1970 & 3.2 & Non-Operating & Shut down in 2011 due to civil war \\
Abu Dhabi & Das Island & 1977 & 5.8 & Operating & \\
Qatar & Ras Laffan (Qatargas 1 T1-3) & 1999 & 10 & Operating & Expansion in 2005 \\
Oman & Oman LNG (T1-T2) & 2000 & 6.7 & Operating & \\
Oman & Qalhat (Oman LNG T3) & 2005 & 3.7 & Operating & \\
Qatar & Ras Laffan (Rasgas 1 T1 \&2) & 2000 & 6.6 & Operating & \\
Qatar & Ras Laffan (Rasgas 2 - T1) & 2004 & 9.4 & Operating & \\
Qatar & Ras Laffan (Rasgas 2- T3) & 2007 & 4.7 & Operating & \\
Qatar & Ras Laffan (Qatargas 2 - T1-T2) & 2009 & 15.6 & Operating & \\
Qatar & Ras Laffan (Rasgas 3 - T1 \& T2) & 2009 & 15.6 & Operating & \\
Yemen & Balhaf (T1-T2) & 2009 & 6.7 & Operating & \\
Qatar & Ras Laffan (Qatargas 3 - T1) & 2010 & 7.8 & Operating & \\
Qatar & Ras Laffan (Qatargas 4 - T1) & 2011 & 7.8 & Operating & \\
Iran & Iran LNG & Unknown & 10.8 & Under & \\
& & & & Construction & \\
\hline
\end{tabular}

Source: See Appendix E for details. "Proposed" LNG projects are those where a source was available for cost, capacity and start year, while "announced" are projects where a source was available for start year and capacity, and where there is no evidence of cancellation.

Qatar has the largest LNG export capacity in the world with a capacity of 77.5 MMTPA. Sixtyeight per cent of total Qatari LNG exports between 1993 and 2012 have gone to Asia. ${ }^{166}$ Qatar has the third-largest gas resource in the world, with 885.1 trillion cubic feet. ${ }^{167}$ Although Qatar has ample reserves, there do not appear to be any immediate plans to expand LNG export capacity.

Yemen has a 6.7 MMTPA two-train LNG export facility that went into operation in 2009. Oman LNG is a 6.7 MMTPA facility that started in 2000. Qalhat LNG is a 3.7 MMTPA export facility that is considered to be the third train of Oman LNG, but is owned separately by Qalhat LNG. ${ }^{168}$ The three-train ADGAS facility in Abu Dhabi has a capacity of 5.8 MMTPA. The plant receives feed gas from natural gas fields as well as associated gas from oil production. ${ }^{169}$ Iran does not have any LNG export facilities in spite of having the largest reserve position in the world at 1,187.3 trillion cubic feet. ${ }^{170}$ Previously planned projects with external investors

\footnotetext{
${ }^{166}$ Authors' calculations, based on: IEA, "World - Natural gas imports."

${ }^{167}$ BP, BP Statistical Review (2012).

${ }^{168}$ Oman LNG website, "In Brief," http://www.omanlng.com/tabid/158/Default.aspx.

${ }^{169}$ Adgas website, “Our Plant," http://www.adgas.com/En/SitePages/Our\%20Business/Our\%20Plant.aspx.

${ }^{170}$ BP, BP Statistical Review (2012).
} 
have been suspended, having been hampered by sanctions. ${ }^{171}$ Iran is developing on its own a 10.5 to 10.8 MMTPA project called Iran LNG,${ }^{172}$ which is currently under construction. ${ }^{173}$

\subsection{Remaining LNG Projects around the world}

The rest of the world represents about 19 per cent of the global LNG trade. Most planned projects are primarily in Africa, where a number of LNG-liquefaction facilities currently operate. The following table summarizes other current LNG-liquefaction capacity in the world not included above, or in Canada.

\section{TABLE 5.7: OTHER LNG EXPORT PROJECTS}

\begin{tabular}{|l|l|r|r|l|l|}
\hline Location & \multicolumn{1}{|c|}{ Name } & $\begin{array}{c}\text { Completion } \\
\text { Year }\end{array}$ & \multicolumn{1}{|c|}{ MMTPA } & Status & Notes \\
\hline Algeria & Arzew GL 1Z & 1981 & 7.9 & Operating & \\
Algeria & Arzew GL 2Z & 1972 & 8.3 & Operating & \\
Algeria & Skikda T1 & 1971 & 0.85 & Operating & \\
Algeria & Skikda T2 \& T3 & 1973 & 1.7 & Non-operating & Destroyed in 2004 \\
Algeria & Skikda T4 & 1981 & 0.85 & Non-operating & Destroyed in 2004 \\
Algeria & Skikda T5 & 1981 & 1.25 & Operating & \\
Algeria & Skikda T6 & 1981 & 1.25 & Operating & \\
Algeria & Skikda Rebuild & 2013 & 4.5 & Operating & \\
Angola & Angola Soyo LNG Terminal & 2013 & 5.2 & Operating & \\
Egypt & Damietta & 2005 & 5 & Operating & \\
Egypt & Idku & 2005 & 7.2 & Operating & \\
Equatorial Guinea & Bioko Island & 2007 & 3.7 & Operating & \\
Nigeria & Bonny Island NLNG T1 & 1999 & 3.2 & Operating & \\
Nigeria & Bonny Island NLNG T2 & 2000 & 3.2 & Operating & \\
Nigeria & Bonny Island NLNG T3 & 2002 & 3.2 & Operating & \\
\hline
\end{tabular}

Source: See Appendix E for details. "Proposed" LNG projects are those where a source was available for cost, capacity and start year, while "announced" are projects where a source was available for start year and capacity, and where there is no evidence of cancellation.

\footnotetext{
${ }^{171}$ Robert Tuttle and Yeganeh Salehi, "Iran Burning \$7 Billion to Lead Gas OPEC as It Faces Sanctions," Bloomberg, November 3, 2013, http://www.bloomberg.com/news/2013-11-03/iran-burning-7-billion-seeks-to-lead-gas-opecfacing-u-s-lng.html.

172 ibid.

${ }^{173}$ Iran LNG website, "Current Status," http://www.iranlng.ir/en/our-project/current-status.
} 


\section{CANADA AS AN LNG SUPPLIER}

\subsection{Historical Markets for Canadian Gas}

Developments in the U.S. Lower 48 have and will continue to have an impact on the Canadian natural gas industry. In the Lower 48, dry gas production increased by 17 per cent from 1.57 $\mathrm{BCM} / \mathrm{d}$ in January 2010 to $1.85 \mathrm{BCM} / \mathrm{d}$ in December $2011 .{ }^{174}$ Beginning in 2012, U.S. production began to level off, except in the Marcellus in the East, where it continues to increase. ${ }^{175}$

The U.S. Lower 48 has served as the export market for Canadian natural gas. Development of shale gas and other tight-gas resources in the U.S. has slowly been displacing imported gas from Canada while simultaneously increasing exports of gas to Eastern Canada. Figure 6.1 illustrates the Canadian gas export/import trends with the U.S. The U.S. has become a declining market for Canadian gas exports, leaving LNG as the only other option to export Canadian gas.

\section{FIGURE 6.1: U.S. IMPORTS AND EXPORTS FROM CANADA}

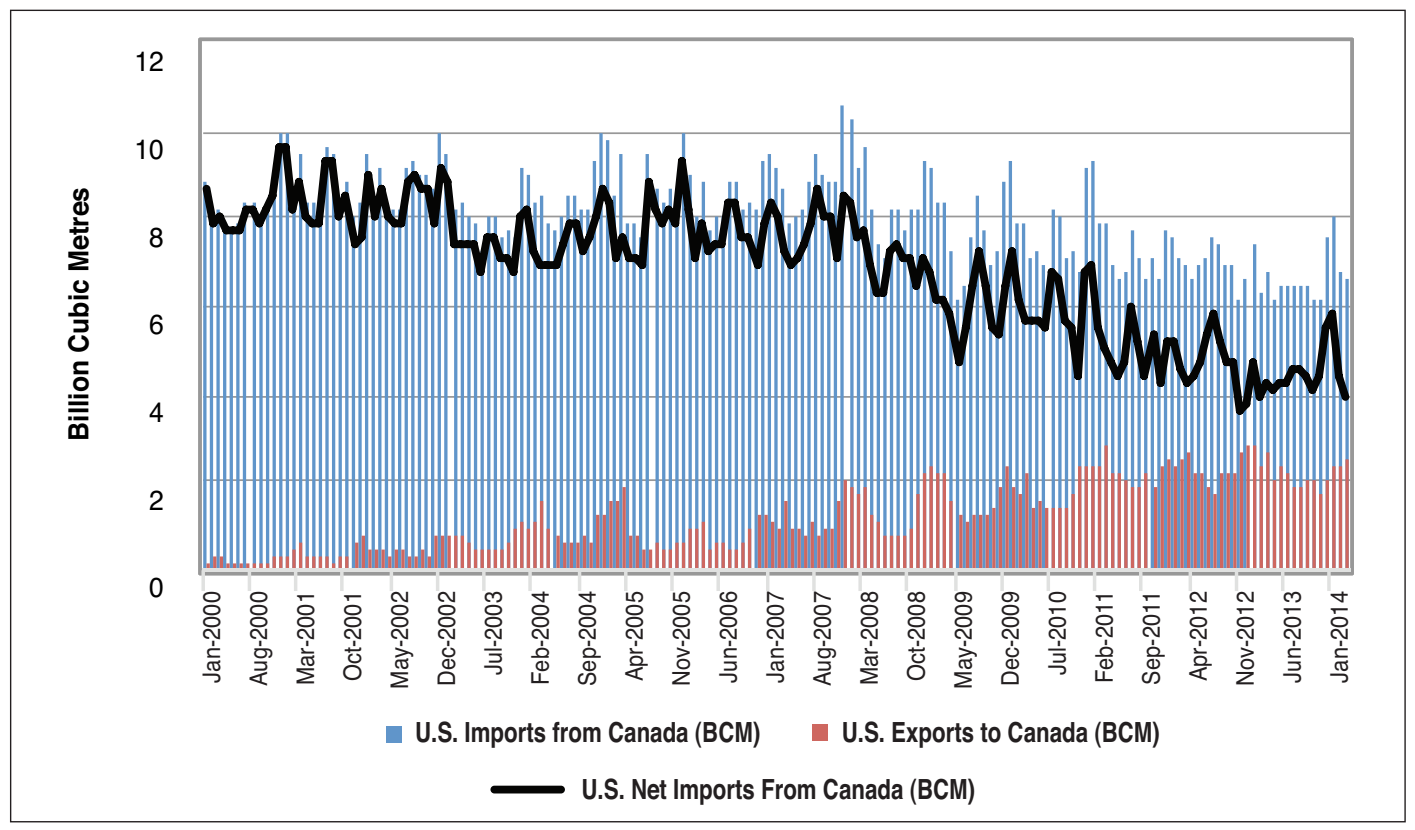

Source: EIA, "U.S. Natural Gas Imports by Country," http://www.eia.gov/dnav/ng/ng_move_impc_s1_m.htm and “U.S. Natural Gas Exports by Country," http://www.eia.gov/dnav/ng/ng_move_expc_s1_m.htm.

\subsection{Canadian Domestic Demand and Supply}

Between 1995 and 2012, Canadian domestic consumption of natural gas grew by 25 per cent, equivalent to a compound annual average rate of 1.3 per cent. ${ }^{176}$ Between 2007 and 2012, consumption slowed, growing by only six per cent over the period. Driven by lower prices,

\footnotetext{
${ }^{174}$ EIA website, “U.S. Dry Natural Gas Production," http://www.eia.gov/dnav/ng/hist/n9070us2m.htm (data accessed April 28, 2014).

${ }^{175}$ EIA, "Marcellus region to provide 18\% of total U.S. natural gas production this month," Today in Energy blog, December 9, 2013, http://www.eia.gov/todayinenergy/detail.cfm?id=14091.

${ }^{176}$ Authors' calculations, based on: CANSIM Table 128-0016 (Statistics Canada category used for domestic demand was "availability").
} 
consumption is expected to increase at an average annual rate of 2.32 per cent between 2015 and 2040. ${ }^{177}$ These figures account for net increases in population, increased power demand and natural gas substitution for coal and other hydrocarbons for power generation, increased demand from oilsands production, and some increases in manufacturing and agriculture. As shown in Figure 6.2, Canadian domestic consumption has remained stable. Export growth figures reflect pipeline shipments to the U.S. and show slight declines over time.

\section{FIGURE 6.2: CANADIAN NATURAL GAS PRODUCTION, TRADE MOVEMENTS, AND DOMESTIC CONSUMPTION}

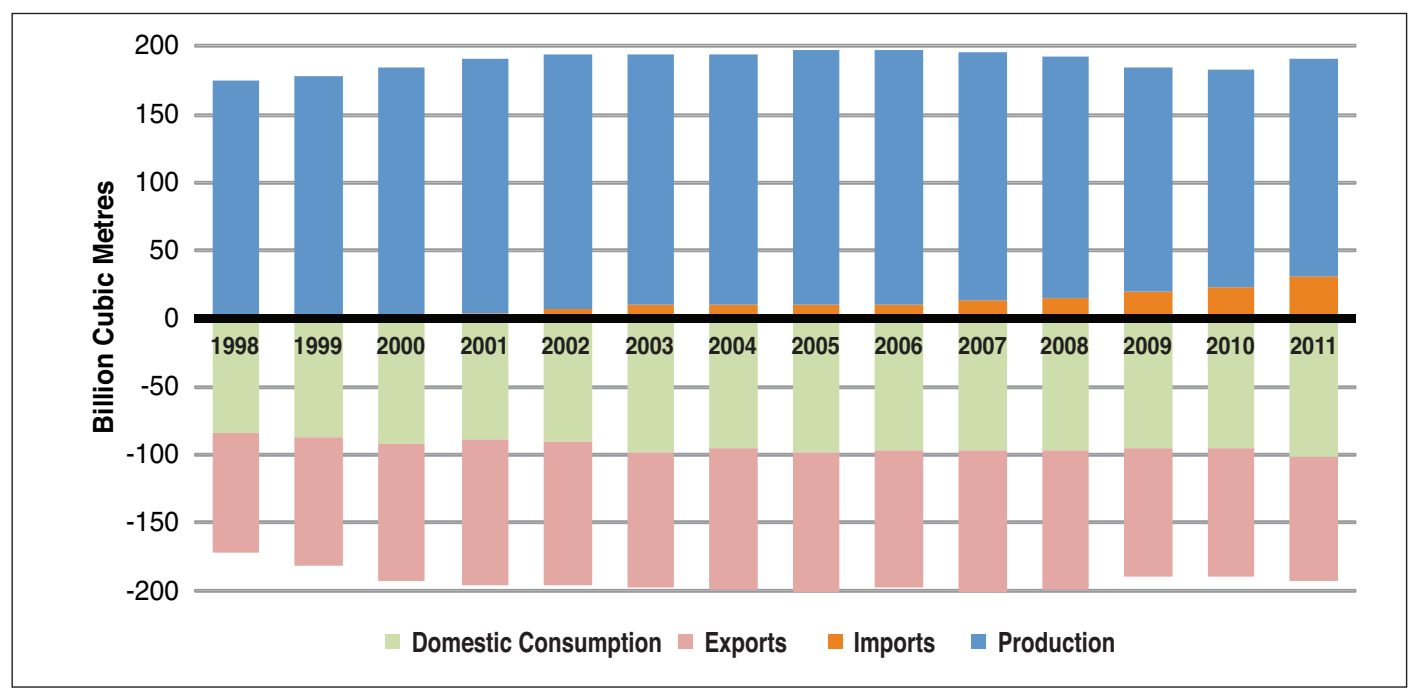

Source: BP, BP Statistical Review of World Energy 2013 Workbook (2013); Canadian Gas Association “Exports, Imports and Sales, annual."

Natural gas demand in Canada has a pronounced seasonal pattern that is reflected in storage volumes. Throughout the summer, when demand for gas-fired heating is low, excess product is stored (see Figure 6.3). Throughout the winter, the stored gas is drawn down as demand rises. However, even when faced with slow increases in gas demand and declining production, gas storage volumes have increased, especially since 2008. Likewise, imports of natural gas from the Eastern U.S. to Eastern Canada have doubled since 2008. ${ }^{178}$ These changes in flows are no coincidence, and are the result of newly revived competition from U.S. gas producers exploiting plentiful shale gas resources in the Marcellus, Utica and Barnett shales, among others.

\footnotetext{
${ }^{177}$ EIA, International Energy Outlook 2013, Figure 43.

${ }^{178}$ EIA, International Energy Outlook 2013.
} 


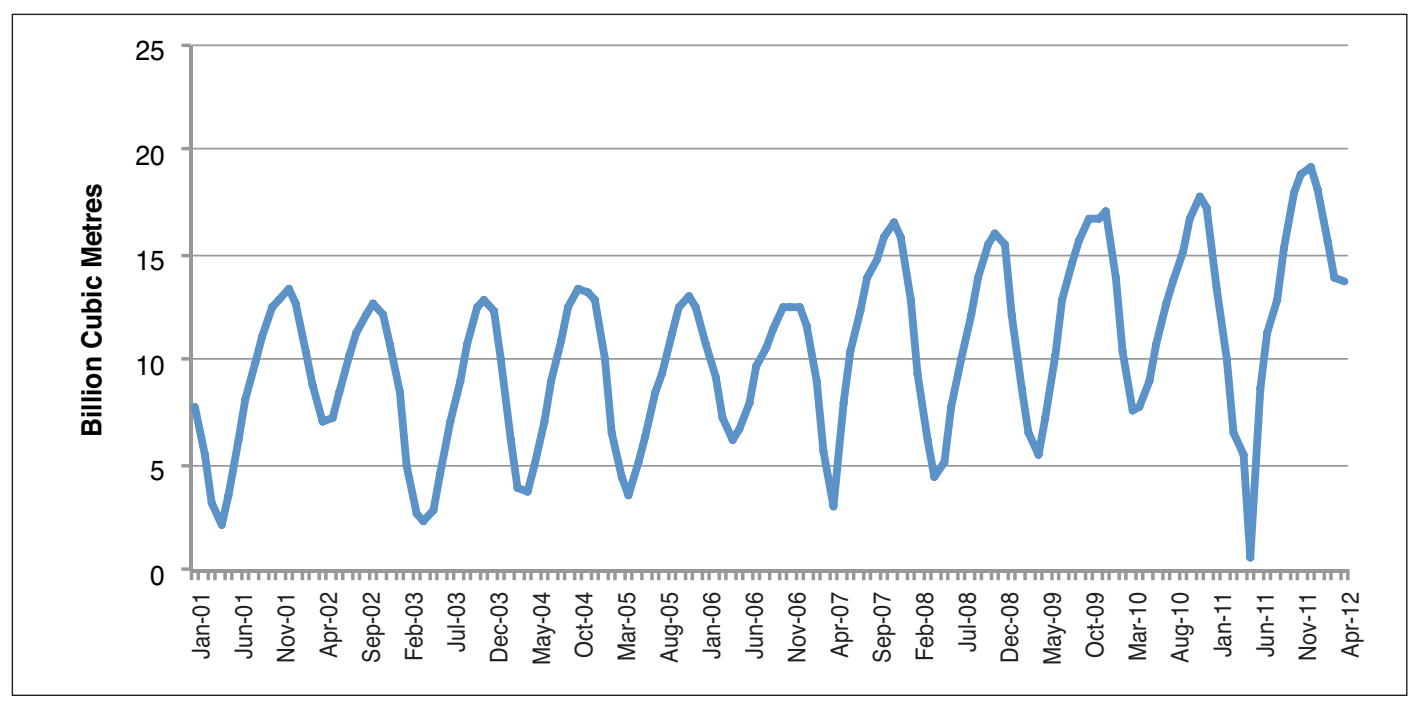

Source: Natural Resources Canada, Canadian Natural Gas Monthly Market Update: Historical Data, http://www.nrcan.gc.ca/energy/sources/natural-gas/monthly-market-update/1173.

Natural gas is displacing coal-fired generation in terms of retirements and new-build capacity in both Canada and the U.S.. The National Energy Board projects a 27 per cent increase in electricity-generating capacity by 2035 , with "natural gas-fired and renewable-based capacity showing the largest increases." ${ }^{179}$ Specificially, gas-fired capacity is expected to increase from $18 \mathrm{GW}$ in 2010 to $28 \mathrm{GW}$ in 2035 . $^{180}$ These increases come largely at the expense of coal- and coke-based power generation, as emissions concerns and competitive natural gas prices present a comparative advantage. These advantages explain why the switch to gas-fired generation is expected to be most pronounced in Alberta, where growth in co-generation capacity from oilsands producers and a gradual decommissioning of coal-fired capacity is taking place. ${ }^{181}$

When viewed by sector (Figure 6.4), the key drivers of Canadian domestic demand have been the industrial sector and mining/oil-and-gas extraction industries. Of the major users depicted, only transformation to electricity and mining and oil and gas increased consumption between 2002 and 2012. In 2012, natural gas use by mining and oil and gas was 605 PJ or 15 BCM. The National Energy Board predicts natural gas use in the oilsands will increase to $34.7 \mathrm{BCM}$ in 2035, suggesting the oil and gas sector will be the major source of domestic demand growth in the future. ${ }^{182}$ The net result is that some domestic demand will help offset the diminishing export market in the United States.

\footnotetext{
${ }^{179}$ National Energy Board, Canada's Energy Future: Energy Supply and Demand Projections to 2035 (November 2011), http://www.neb-one.gc.ca/clf-nsi/rnrgynfmtn/nrgyrprt/nrgyftr/2011/nrgsppldmndprjctn2035-eng.html. 
The natural gas markets of Canada and the United States are physically connected via pipelines and subject to similar drivers of supply and demand. With the United States traditionally importing Canadian-produced natural gas, it remains an important market for Canada. Overall, American growth in natural gas consumption has been slower than Canada's, with a compound annual rate of growth of 0.98 per cent since 1998 (consumption in Canada grew at 1.35 per cent). ${ }^{183}$ The EIA expects U.S. growth to slow to a rate of only 0.62 per cent a year until $2025 .{ }^{184}$ Demand for gas within Canada, currently at about $252 \mathrm{MMCM} / \mathrm{d}$, is seen as growing by 2.58 per cent per year on average through the same time period.

FIGURE 6.4: CANADIAN NATURAL GAS USE BY SECTOR 2002 - 2012

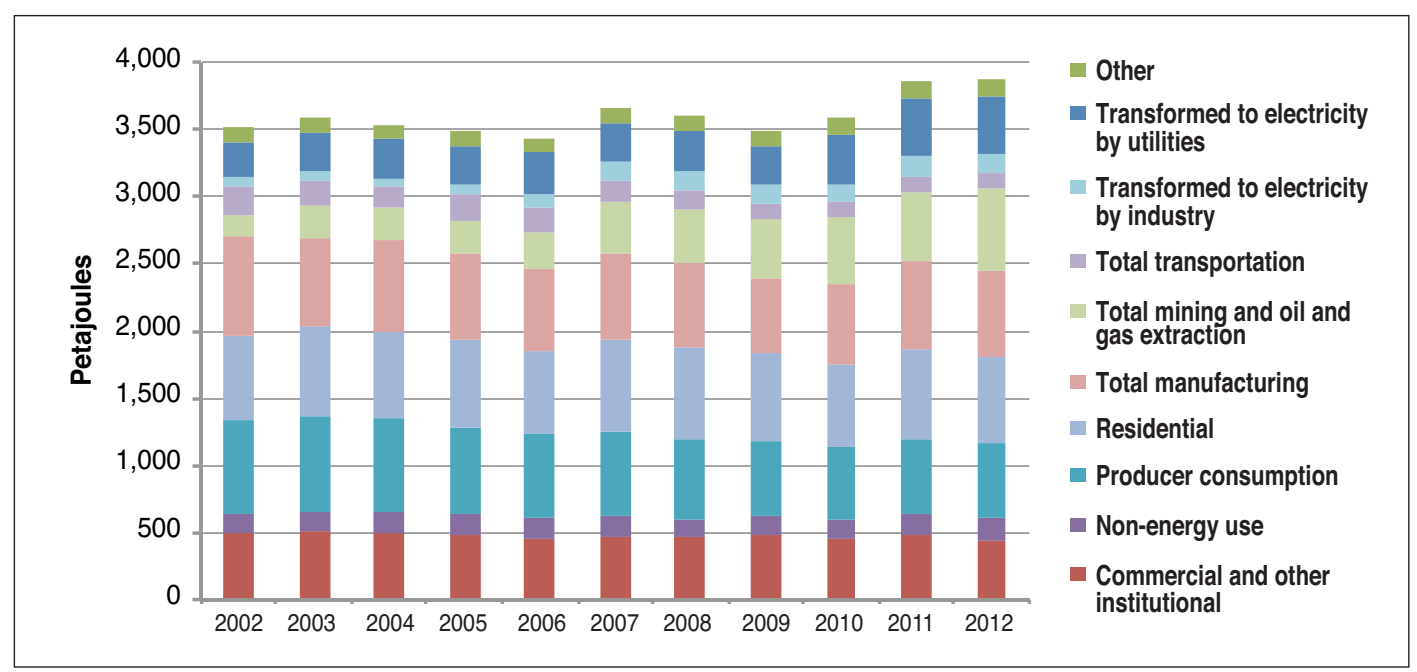

Notes: "Other" includes agriculture; construction; public administration; forestry, logging and support activities; transformation to steam generation; and transformation to refined petroleum products. "Producer consumption" is the consumption by the producing industry of its own produced fuel. Non-energy use is natural gas used for non-fuel purposes.

Source: Statistics Canada, CANSIM Table 128-0016, "Supply and demand of primary and secondary energy in terajoules."

\subsubsection{CANADIAN NATURAL GAS BASINS}

Canada has an estimated 1,660 BCM (58.6 TCF) of remaining established natural gas reserves, with approximately 94 per cent of those found in British Columbia and Alberta. ${ }^{185}$ Most of Canada's shale gas, by known reserve volume, is in the Horn River/Liard basins in Northeastern British Columbia, and in the Montney formation in Northeastern B.C. and Western Alberta (see Figure 6.7). Drilling in these basins has been limited in the past by low natural gas prices, limited infrastructure and lack of market demand. Prices at the Alberta AECO hub traded (on average) \$0.56/GJ below NYMEX Henry Hub between 2008 and 2013. ${ }^{186}$ This differential tends to make most new drilling projects uneconomical unless there

\footnotetext{
${ }^{183}$ Derived from: BP, BP Statistical Review of World Energy June 2009 (2009); and BP, BP Statistical Review (2013).

${ }^{184}$ Derived from: EIA, International Energy Outlook 2013, Figure 43 Data.

${ }^{185}$ National Energy Board, Canadian Energy Overview 2012, Appendix 2.

${ }^{186}$ Authors' calculations, based on prices retrieved from World Bank Historical Commodity Price Data (Henry Hub) and Bloomberg (AECO, ticker NGCDAECO).
} 
are liquids associated with the gas. The Canadian Gas Association data show that natural gas exports to the U.S. were 105.1 BCM (10.28 BCF/d) in 2005 and fell to $91.7 \mathrm{BCM}$ (8.97 $\mathrm{BCF} / \mathrm{d})$ in 2011 - a 12.75 per cent decline.${ }^{187}$ Regional domestic demand is primarily increasing due to expanding demand for natural gas in the oilsands; overall exports to the U.S. are not increasing, primarily because of new development in the Bakken, Utica and Marcellus shale formations.

Recent trends toward American self-sufficiency in natural gas have the potential to weaken long-term demand for Canadian products. The result has been regional supply-surpluses and flat price-levels. As a consequence, Canadian producers have begun to examine the feasibility of constructing new east/west pipelines and export terminals to reduce surplus and develop new markets. In the process, however, they face challenges in domestic politics and capital availability $^{188}$ and the potential for established, low-cost competition in the marketplace.

When considering access and supply to serve Asia-Pacific nations, the most accessible formations from both British Columbia and Alberta are found in northern regions. These are shown in Tables 6.1 and 6.2 below, and reflect relative characteristics of dry to wet for each formation. ${ }^{189}$

The reserves in Western Canada with the highest gas liquid content - the Montney, Duvernay, and Muskwa - are all found in Northern Alberta or Northeast British Columbia. Not only do these plays have the highest ratio of natural gas liquids (NGLs) to dry gas, but also the largest absolute amount of natural gas liquids. The gas play most likely to be productive is the Montney, a resource shared by both British Columbia and Alberta. This formation is characterized by both dry gas and natural gas liquids. Depending on market conditions, NGLs can have greater value for oilfield operations domestically and in the United States, and operators may choose to separate NGLs prior to shipment.

Figure 6.5 shows the volume of Canada's proved reserves ${ }^{190}$ and the reserves-to-production $(\mathrm{R} / \mathrm{P})$ ratio, which determines how many years of reserves are left given annual natural gas production rates. The R/P ratio closely follows reserves, and both have leveled off following the fall in North American natural gas prices. Based on production rates from 2012, Canada has enough reserves to produce the same amount of natural gas for 12 years. Canada's consumption in 2012 was 64 per cent of total production, compared to the U.S., where consumption was 105 per cent of production in 2012. ${ }^{191}$

\footnotetext{
${ }^{187}$ Canadian Gas Association, "Canadian Natural Gas Exports, Imports and Domestic Sales,” http://www.cga.ca/wpcontent/uploads/2011/02/Chart-11-Exports-Imports-Sales2.pdf.

${ }^{188}$ Recent investments from Asia-Pacific countries, including state-owned companies such as CNOOC, highlight the reliance on foreign capital to sustain investment in Canadian hydrocarbon development.

${ }^{189}$ See Appendix B for a description of natural gas characteristics.

${ }^{190}$ Proved (or proven) reserves are typically defined as a quantity of energy sources estimated with reasonable certainty, from the analysis of geologic and engineering data, to be recoverable from well-established or known reservoirs with the existing equipment and under the existing operating conditions. This should be distinguished from probable or possible reserves, which have a lower probability of being recoverable.
}

${ }^{191}$ BP, BP Statistical Review (2013). 
TABLE 6.1: NATURAL GAS RESERVES IN CANADA (BCM)

\begin{tabular}{|c|c|c|c|c|c|}
\hline & $\begin{array}{l}\text { Source and } \\
\text { (Data Year) }\end{array}$ & $\begin{array}{l}\text { CAPP } \\
\text { (2012) }\end{array}$ & $\begin{array}{c}\text { NEB } \\
\text { (Established 2011, } \\
\text { Ultimate 2012) }\end{array}$ & $\begin{array}{l}\text { NEB - Conventional } \\
\text { Only (2009) }\end{array}$ & $\begin{array}{l}\text { CANSIM } \\
(2010)\end{array}$ \\
\hline \multirow[t]{2}{*}{ British Columbia } & Established Reserves & 805.76 & 555 & & 533.3 \\
\hline & Ultimate Potential & & 10,642 & $1,345(1)$ & \\
\hline \multirow[t]{2}{*}{ Alberta } & Established Reserves & 972.4 & 1,007 & & $1,064.7$ \\
\hline & Ultimate Potential & & 6,994 & 2,201 & \\
\hline \multirow[t]{2}{*}{ Saskatchewan } & Established Reserves & 60.06 & 59 & & 63.7 \\
\hline & Ultimate Potential & & 86 & 106 & \\
\hline \multirow[t]{2}{*}{ Ontario } & Established Reserves & 19.21 & 18 & & 19.5 \\
\hline & Ultimate Potential & & & 33 & \\
\hline \multicolumn{6}{|l|}{ Maritimes, } \\
\hline \multirow[t]{2}{*}{ Newfoundland and Labrador } & Established Reserves & 9.57 & 8 & & 7.8 \\
\hline & Ultimate Potential & & & $2,591(2)$ & \\
\hline \multirow[t]{2}{*}{ Northern Canada } & Established Reserves & & & & \\
\hline & Ultimate Potential & & & $3,285(3)$ & \\
\hline
\end{tabular}

Notes: (1) Includes West Coast Intermontane and Offshore; (2) includes Labrador, East Newfoundland Basin, Grand Banks, Southern Grand Banks, Laurentian Sub-Basin, Nova Scotia, George's Bank, and Gulf of St. Lawrence; (3) includes Northwest Territories - Colville Hills, Mackenzie-Beaufort, Yukon-Eagle Plains and others, Arctic Islands, Eastern Arctic, and Hudson Bay.

Sources: Canadian Association of Petroleum Producers, Statistical Handbook (2013); National Energy Board, "Ultimate Potential for Unconventional Natural gas in Northeastern B.C. Horn River Basin," (Table 2.4a); National

Energy Board, Canadian Energy Overview 2012 (Appendix 2); National Energy Board, Energy Briefing Note: The

Ultimate Potential for Unconventional Petroleum from the Montney Formation of British Columbia and Alberta (November 2013), 6; Statistics Canada, CANSIM Table 153-0014.

FIGURE 6.5: NATURAL GAS PROVED RESERVES AND RESERVES-TO-PRODUCTION RATIO (1993 - 2012)

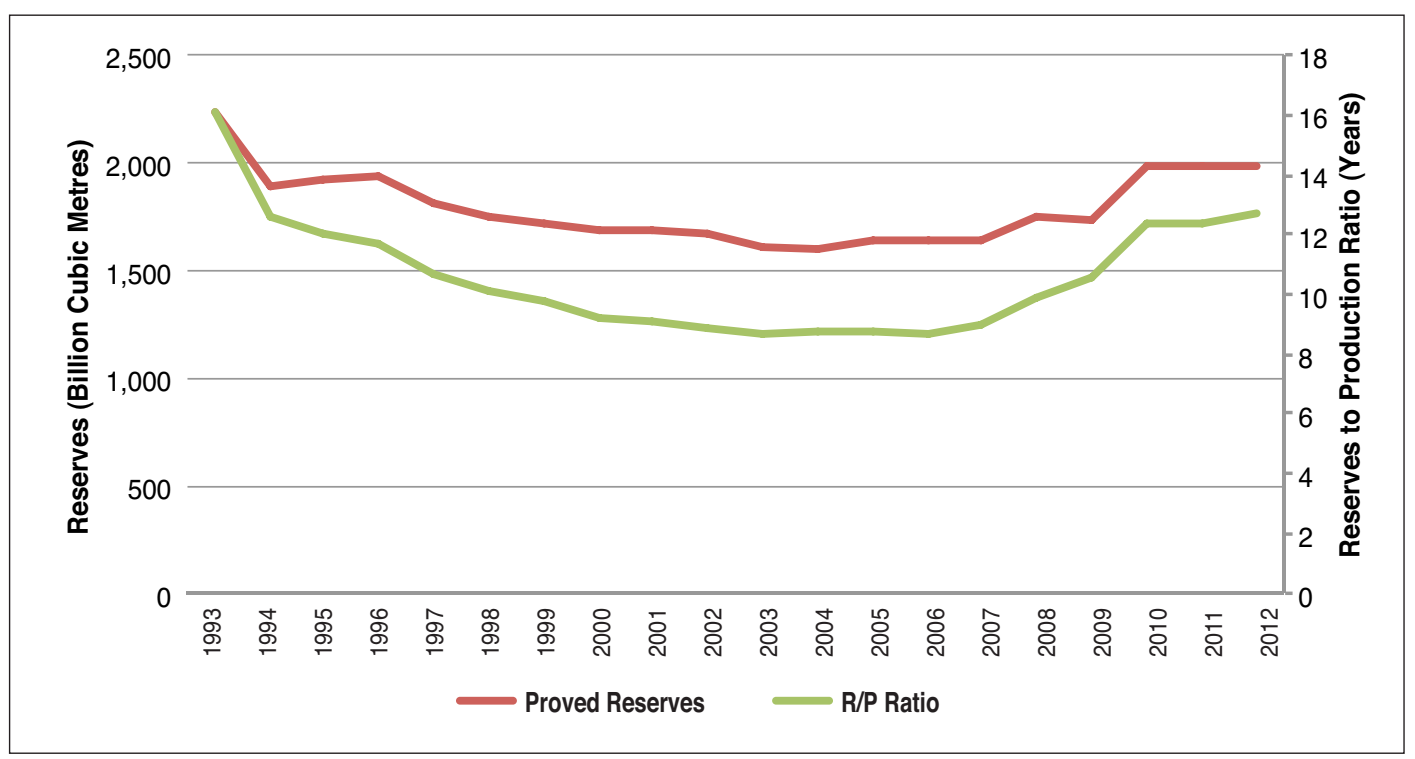


TABLE 6.2: SHALE- AND TIGHT-GAS RESERVES IN BRITISH COLUMBIA AND ALBERTA

\begin{tabular}{|c|c|c|c|c|c|c|c|c|}
\hline \multirow{2}{*}{$\begin{array}{c}\text { Play Name } \\
\text { (* Indicates a preliminary } \\
\text { estimate) }\end{array}$} & \multirow{2}{*}{$\begin{array}{c}\text { Origin by Province } \\
\text { (\% of medium case dry gas) }\end{array}$} & \multicolumn{3}{|c|}{$\begin{array}{l}\text { Ultimate Potential Dry Gas Estimates } \\
\text { (BCM) }\end{array}$} & \multirow{2}{*}{\begin{tabular}{|c|} 
Ratio BCM \\
Dry Gas to \\
MMCM \\
NGL \\
(Medium \\
Case) \\
\end{tabular}} & \multicolumn{3}{|c|}{$\begin{array}{l}\text { Ultimate Potential NGL } \\
\text { Estimates (MMCM) }\end{array}$} \\
\hline & & Low & Medium & High Case & & Low & Medium & High Case \\
\hline Cordova & British Columbia & 574.83 & 1 & $2,293.66$ & & & & \\
\hline Doig Phosphate & British Columbia & 713.58 & 1 & $2,851.51$ & & & & \\
\hline Horn River & British Columbia & 10,466 & 12,629 & 14,894 & & & & \\
\hline Liard & British Columbia & $1,359.21$ & 2 & $5,946.54$ & & & & \\
\hline Montney & British Columbia (48\%) & 42,435 & 55,664 & 69,630 & $1: 3.64$ & 11,974 & 15,310 & 19,172 \\
\hline Montney & Alberta (52\%) & 45,917 & 60,095 & 79,684 & 1:13.11 & 1,852 & 4,583 & 8,631 \\
\hline Basal Banff/Exshaw* & Alberta & 446 & 993 & 1,975 & $1: 66.2$ & 5 & 15 & 35 \\
\hline Duvernay & Alberta & 9,934 & 12,479 & 15,219 & $1: 6.94$ & 1190 & 1,798 & 2,589 \\
\hline Muskwa & Alberta & 8,132 & 11,812 & 14,839 & $1: 5.02$ & 949 & 2,350 & 4,181 \\
\hline Nordegg* & Alberta & 1,968 & 4,164 & 7,905 & 1:18.26 & 77 & 228 & 555 \\
\hline Wilrich* & Alberta & 3,237 & 6,918 & 16,007 & 1:21.16 & 109 & 327 & 707 \\
\hline Total & & $125,182.62$ & 164,758 & $231,244.71$ & $1: 6.69$ & 16,156 & 24,611 & 35,870 \\
\hline
\end{tabular}

Notes: ${ }^{(1)}$ : Used Risked Technically Recoverable Resource (Low) - Risked Resource In-Place (High);

${ }^{(2)}$ : Used Marketable Gas (Low) - Gas In Place (High)

Sources:

(1) National Energy Board, Energy Briefing Note: The Ultimate Potential for Unconventional Petroleum from the Montney Formation of British Columbia and Alberta (November 2013), 5, Tables 2 and 3, http://www.neb-one.gc.ca/clfnsi/rnrgynfmtn/nrgyrprt/ntrlgs/Itmtptnt/mntnyfrmtn2013/ItmtptntImntnyfrmtn2013-eng.pdf.

(2) EIA, Technically Recoverable Shale Oil and Shale Gas Resources (2013), I-3.

(3) National Energy Board: Energy Briefing, 9, Table 2.1.

(4) Nathan Vanderklippe, "Massive B.C. reservoir could double gas output," The Globe and Mail, June 14, 2012, http://www.theglobeandmail.com/globe-investor/massive-bc-reservoir-could-double-gas-output/article4264200/.

(5) ERCB, ST98-2013 Alberta's Energy Reserves 2012 and Supply/Demand Outlook 2013-2011 (2013), 2-9, Table 2.1.

Well drilling activity closely parallels the trading hub price of gas (lagged by a predictable amount) and is subject to rig and personnel availability. This is evident in Figure 6.6 below, which highlights the recent downward trend in gas prices and drilling activity. It can be expected that without new export markets and the tidewater-port capacity to access those markets, prices and drilling activity will remain low. 


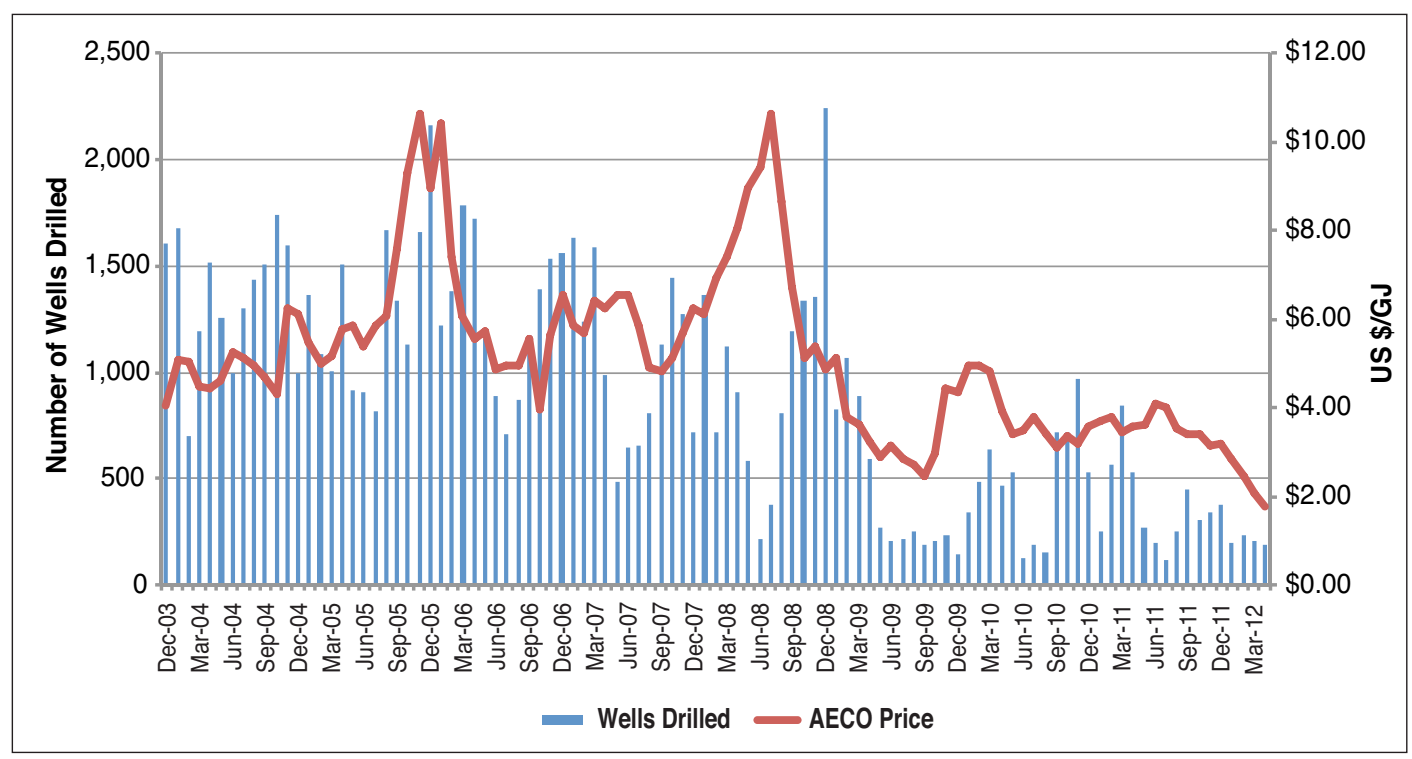

Source: Natural Resources Canada, “Canadian Natural Gas Monthly Market Update: Historical Data," http://www.nrcan.gc.ca/energy/sources/natural-gas/monthly-market-update/1173.

\subsection{Developing LNG Exports}

Low natural gas prices and newly developed shale resources in North America have spurred substantial interest in the potential for leveraging the B.C. Pacific coast as a way to develop new export markets for Canadian gas producers. The only available opportunities for Canadian port expansion that would efficiently serve the Asia-Pacific region in the near term are on the northern coast of B.C. ${ }^{192}$ There are challenges for any site development that include Aboriginal land ownership and access, mountainous terrain, coastal land constraints and marine-safety issues, as well as political/fiscal issues involving other provinces.

Given their significant infrastructure requirements, LNG export terminals are extremely capital intensive. The large investment necessary is compounded in British Columbia, as most proposed terminals and their proposed connecting pipelines are located in remote areas with difficult terrain for pipeline location.

\subsubsection{PROPOSED PORT LOCATIONS}

There are nine projects along British Columbia's coast that have already secured LNG export licences from Canada's National Energy Board, and another three applications are under review (Table 6.4). Two additional projects in Oregon have also secured export licences from the National Energy Board. Two more projects have been proposed for the B.C. coast, but very

\footnotetext{
${ }^{192}$ Later opportunities may be found in the Northwest Passage and the coasts of the Canadian territories. In addition, Canaport LNG on Canada's East Coast may convert to an export terminal (fed by U.S. shale gas) as it could feasibly serve demand from Europe or Western Asia. There are two additional export terminals proposed for Canada's East Coast: Goldboro LNG and H-Energy LNG.
} 
little information is available about them. The total approved export capacity is 183.145 MMTPA (249 BCM), compared to marketable production of 141 BCM in 2013, though less than peak production of $188 \mathrm{BCM}$ in 2006 . The remaining projects have a planned capacity of 10 to 35 MMTPA. ${ }^{193}$

There are seven proposed locations for facilities on the B.C. coast (see Figure 6.7). We have illustrated these potential export locations within "zones," since all but Kitsault and Woodfibre have at least two potential liquefaction sites. ${ }^{194}$ Pipeline developers are involved as well, planning to deliver Horn River/Liard and Montney gas to the eventual export sites. One includes a 530-mile pipeline from Northeastern British Columbia to Prince Rupert, while another would create a 287-mile pipeline from Summit Lake to Kitimat.

\section{FIGURE 6.7: PROPOSED TERMINAL LOCATIONS AND PIPELINE NETWORK}

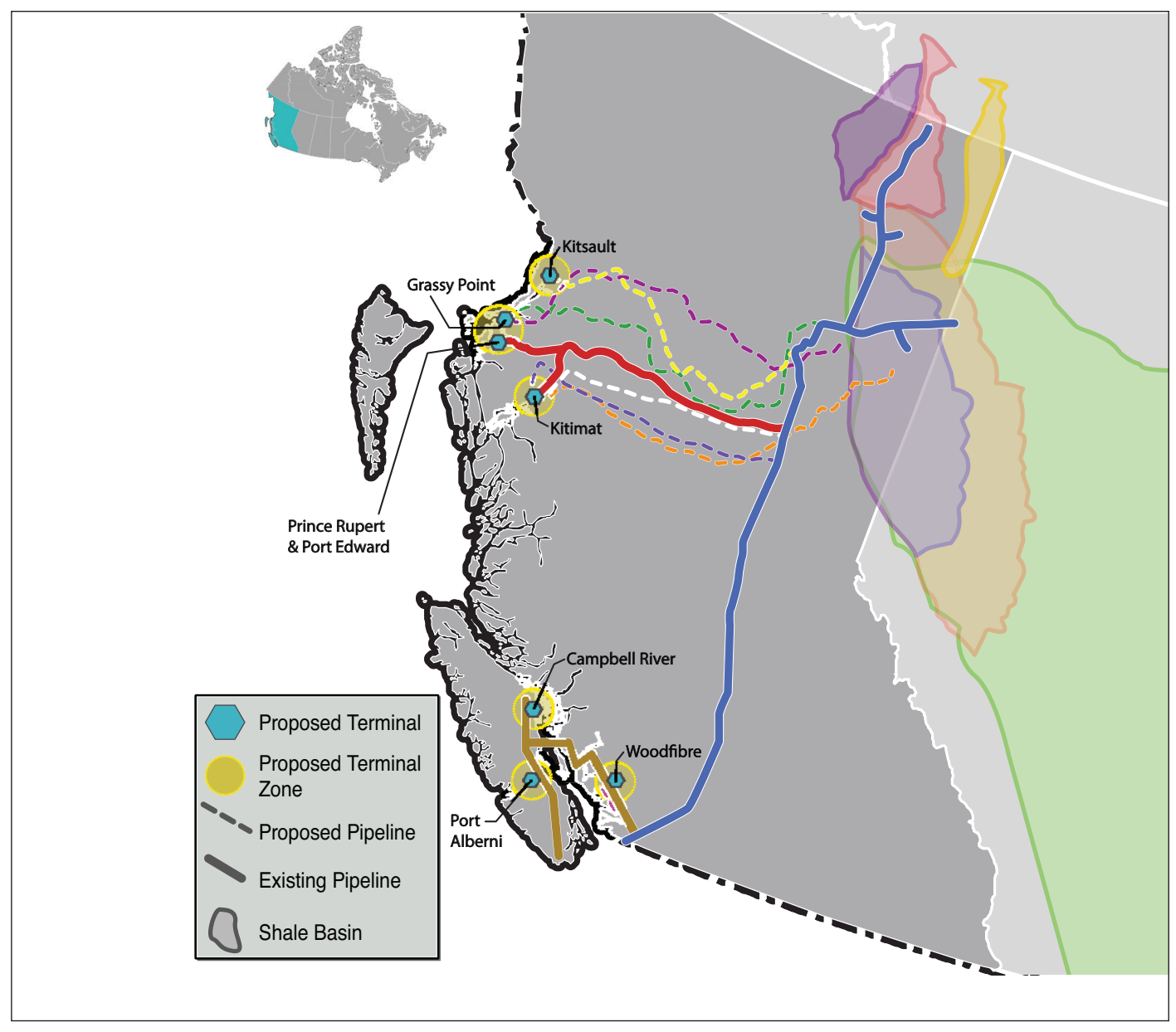

Source: See Appendix C.

\footnotetext{
${ }^{193}$ We note that not all projects, even those with export licences, are guaranteed to proceed, or even export their maximum allowable amount if constructed.

${ }^{194}$ The attraction of these sites is not limited to LNG. Opportunities for crude-oil shipping facilities, liquefied petroleum gas or derivatives, and return pipeline capability for condensate or other products provide attractive co-location alternatives for developers.
} 
TABLE 6.3: PROPOSED LNG EXPORT FACILITIES IN BRITISH COLUMBIA AND THE NORTHWEST UNITED STATES

\begin{tabular}{|c|c|c|c|c|c|c|}
\hline Location & Asset Name & Ownership & $\begin{array}{l}\text { Capacity } \\
\text { (MMTPA) }\end{array}$ & $\begin{array}{l}\text { NEB Export } \\
\text { Application } \\
\text { Status and } \\
\text { Length }\end{array}$ & \begin{tabular}{|c|} 
NEB \\
Maximum \\
Annual \\
Export \\
Allowance \\
(MMTPA)
\end{tabular} & $\begin{array}{l}\text { Expected } \\
\text { Start Date }\end{array}$ \\
\hline Kitimat, B.C. & $\begin{array}{l}\text { Douglas Channel } \\
\text { Energy Project }\end{array}$ & $\begin{array}{l}\text { Haisla Nation/LNG Partners } \\
\text { (50\%), Golar LNG (25\%), } \\
\text { unnamed Asian investor (25\%) }\end{array}$ & 1.8 & $\begin{array}{l}\text { Approved; } \\
20 \text { years }\end{array}$ & 1.98 & 2015 \\
\hline Kitimat, B.C. & $\begin{array}{l}\text { Kitimat LNG } \\
\text { Terminal }\end{array}$ & $\begin{array}{l}\text { Apache Canada Ltd. (50\%), } \\
\text { Chevron Corp. (50\%) }\end{array}$ & 5 & $\begin{array}{l}\text { Approved; } \\
20 \text { years }\end{array}$ & 11 & 2017 \\
\hline Kitsault, B.C. & Kitsault & $\begin{array}{l}\text { Kitsault Energy and a } \\
\text { Memorandum of Understanding } \\
\text { signed "with an Asian oil and gas } \\
\text { major" }\end{array}$ & 5 & $\begin{array}{l}\text { Under } \\
\text { review; } 25 \\
\text { years }\end{array}$ & 2.53 & 2017 \\
\hline Woodfibre, B.C. & Woodfibre LNG & $\begin{array}{l}\text { Woodfibre (Pacific Oil \& Gas } \\
\text { Group) }\end{array}$ & 2.1 & $\begin{array}{l}\text { Approved; } \\
25 \text { years }\end{array}$ & 2.645 & 2017 \\
\hline $\begin{array}{l}\text { Kitimat or Prince } \\
\text { Rupert, B.C. }\end{array}$ & Triton LNG & $\begin{array}{l}\text { AltaGas Ltd. (50\%), Idemitsu } \\
\text { Kosan Co. }(50 \%)\end{array}$ & 2.3 & $\begin{array}{l}\text { Approved; } \\
25 \text { years }\end{array}$ & 24.13 & 2017 \\
\hline $\begin{array}{l}\text { Lelu Island, Port } \\
\text { Edward, B.C. }\end{array}$ & $\begin{array}{l}\text { Pacific Northwest } \\
\text { LNG }\end{array}$ & $\begin{array}{l}\text { Petronas (62\%), SINOPEC (15\%), } \\
\text { Indian Oil Corp. (10\%), Japex } \\
(10 \%), \text { Petroleum Brunei }(3 \%)\end{array}$ & 12 & $\begin{array}{l}\text { Approved; } \\
25 \text { years }\end{array}$ & 13.63 & 2018 \\
\hline Coos Bay, Ore. & Jordan Cove LNG & Versen Inc. & 6 & $\begin{array}{l}\text { Approved; } \\
25 \text { years }\end{array}$ & 11.2 & 2018 \\
\hline Astoria, Ore. & Oregon LNG & Oregon LNG & 9.74 & $\begin{array}{l}\text { Approved; } \\
25 \text { years }\end{array}$ & 27.6 & 2019 \\
\hline Campbell River, B.C. & Discovery LNG & $\begin{array}{l}\text { Quicksilver Resources Canada, } \\
\text { and a "to-be-determined third } \\
\text { party" }\end{array}$ & & None & 35.23 & 2019 \\
\hline Kitimat, B.C. & $\begin{array}{l}\text { LNG Canada } \\
\text { Terminal }\end{array}$ & $\begin{array}{l}\text { Shell Canada Ltd. (40\%), } \\
\text { Mitsubishi Corp. (20\%), Korea } \\
\text { Gas Corp. (20\%), PetroChina } \\
(20 \%)\end{array}$ & 12 & $\begin{array}{l}\text { Approved; } \\
25 \text { years }\end{array}$ & 25.6 & 2020 \\
\hline $\begin{array}{l}\text { Kitimat or Prince } \\
\text { Rupert, B.C. }\end{array}$ & WCC LNG & $\begin{array}{l}\text { Imperial Oil Ltd. (50\%), } \\
\text { ExxonMobil Canada (50\%) }\end{array}$ & $10-15$ & $\begin{array}{l}\text { Approved; } \\
25 \text { years }\end{array}$ & 27.6 & 2021-2022 \\
\hline $\begin{array}{l}\text { Ridley Island, Prince } \\
\text { Rupert, B.C. }\end{array}$ & $\begin{array}{l}\text { Prince Rupert } \\
\text { LNG }\end{array}$ & BG Group & 14 & $\begin{array}{l}\text { Approved; } \\
25 \text { years }\end{array}$ & 3.5 & 2021 \\
\hline Grassy Point, B.C. (13) & Aurora LNG & $\begin{array}{l}\text { Nexen (60\%), Inpex Corp. and } \\
\text { JGC Corp. (40\%) }\end{array}$ & 24 & $\begin{array}{l}\text { Approved; } \\
25 \text { years }\end{array}$ & & 2021-2023 \\
\hline Stewart, B.C. & $\begin{array}{l}\text { Stewart Energy } \\
\text { LNG }\end{array}$ & $\begin{array}{l}\text { Canada Stewart Energy Group } \\
\text { Ltd. }\end{array}$ & 5 to 30 & $\begin{array}{l}\text { Under } \\
\text { review; } 25 \\
\text { years }\end{array}$ & & 2017 \\
\hline Grassy Point, B.C. & TBA & Woodside Petroleum & & None & & \\
\hline Vancouver, B.C. & Tilbury LNG & WesPac Midstream LLC & 3 & $\begin{array}{l}\text { Under } \\
\text { review; } 25 \\
\text { years }\end{array}$ & & 2016 \\
\hline
\end{tabular}

Notes: Maximum annual export allowance includes annual tolerance. Dates: Announced date of first export/initial opening. Capacity: Capacity at initial opening, not full potential capacity. 
The B.C. government has signed two long-term agreements for LNG development and for access to the land required to build the terminals, both at Grassy Point, B.C. ${ }^{195}$ The two developers are Woodside Petroleum Ltd. and Aurora LNG (a joint venture led by CNOOC). The B.C. government has also recently signed a letter of intent with Petronas to "work collaboratively to secure long-term investments in British Columbia's Liquefied Natural Gas (LNG) industry" as well as to develop terms of reference for a project-development agreement. ${ }^{196}$

There are an additional three proposed projects/sites with very little information available about them. A South Korean company, SK E\&S, has filed an expression of interest with the B.C. government for the Grassy Point location, but little additional detail is available. Quicksilver Resources has proposed a facility on a former paper-mill site at Campbell River, with an unknown number of trains. Quicksilver reports that it is in discussions with potential joint-venture partners. ${ }^{197}$ Port Alberni, on Vancouver Island, has been promoted by the Port Alberni Port Authority as an alternative location for firms unable to secure agreements for land at Grassy Point. However, there is no project associated with the port as of yet.

A stated goal of the B.C. government is to have at least one LNG pipeline and terminal operating in Kitimat by 2015 and three in operation by $2020 .{ }^{198}$ This goal represents a challenge not only in collaborating with other governments, but completion of a complex pipeline delivery system and, in the end, reaching collaborative agreement with Aboriginal groups who control land and access rights in the pipeline rights of way and the port-facility zones. The government will likely not realize its goal of having at least one terminal in operation by 2015, as it is estimated that even the design and construction of the Douglas Channel Energy Project (the smallest proposed facility) will take two years. The goal of three facilities by 2020 is more reasonable, but will also depend on developments in the LNG market, including competition from the U.S. Gulf Coast and Australia.

\subsubsection{SHIPPING COSTS}

Shipping costs for LNG are competitive and consistent with normal pipeline tolls. Transporting one gigajoule of natural gas 3,000 kilometres via the TransCanada mainline from Empress, Alta. to Dawn, Ont. costs \$1.42, or US\$1.54 (\$1.62 USD/MMBTU). ${ }^{199}$ TransCanada's B.C. leg of the Foothills pipeline system has a current tariff of \$2.61 CDN/GJ (\$2.75 CDN/MMBTU) or $\$ 2.99$ USD/MMBTU. ${ }^{200}$ By comparison, shipping one gigajoule of natural gas approximately 7,735 kilometres to Japan's Senboku LNG terminal from Kitimat, B.C. is expected to cost \$1.21 USD/GJ (\$1.28 USD/MMBTU).

\footnotetext{
${ }^{195}$ Brent Jang, "Australia's Woodside wins B.C. approval for LNG project," The Globe and Mail, January 16, 2014.

${ }^{196}$ Government of British Columbia, "B.C. and PETRONAS commit to developing LNG industry," press release, May 5, 2014, http://www.newsroom.gov.bc.ca/2014/05/bc-and-petronas-commit-to-developing-lng-industry.html.

${ }^{197}$ Discovery LNG website, “Ownership,” http://www.discoverylng.com/project-details/ownership/.

${ }^{198}$ British Columbia Ministry of Energy and Mines, Liquefied Natural Gas: A Strategy for B.C. 's Newest Industry, http://www.gov.bc.ca/ener/popt/down/liquefied_natural_gas_strategy.pdf.

${ }^{199}$ National Post, "National Energy Board approves new tolls for TransCanada's Mainline pipeline,” March 27, 2013, http://business.financialpost.com/2013/03/27/national-energy-board-approves-new-tolls-for-transcanadas-mainlinepipeline/?_1sa=e62c-8de9. Exchange rate used is $\$ 1.00$ Canadian $=$ US $\$ 0.92$.

${ }^{200}$ TransCanada Corp., "TransCanada's - Foothills BC Transportation Rates," $\mathrm{http}: / / \mathrm{www}$. transcanada.com/customerexpress/2768.html. Exchange rate used is $\$ 1.00$ Canadian = US\$0.92.
} 
TABLE 6.4: KITIMAT LNG SHIPPING COST ESTIMATES

\begin{tabular}{|l|c|c|c|}
\hline To: & $\begin{array}{c}\text { Distance from } \\
\text { Stewart World Port }\end{array}$ & $\begin{array}{c}\text { Average Cost } \\
\text { (\$/MMBTU) }\end{array}$ & $\begin{array}{c}\text { Average Cost } \\
\text { (\$/GJ) }\end{array}$ \\
\hline Japan - Senboku Port & 4,177 & 1.11 & 1.05 \\
Japan - Average Distance & 4,203 & 1.11 & 1.06 \\
South Korea - Incheon Port & 4,663 & 1.23 & 1.17 \\
China - Hong Kong & 5,406 & 1.43 & 1.36 \\
China - Average Distance & 5,021 & 1.33 & 1.26 \\
Taiwan - Yun-An LNG Terminal & 5,155 & 1.37 & 1.30 \\
\hline
\end{tabular}

Notes: Stewart World Port is used to approximate the distance to Kitimat. It is located approximately 300 kilometres north of Kitimat in a similar inland location. Average shipping cost of $\$ 0.0002516 /$ nautical mile/GJ, based on observed shipping costs for 4,000-5,400 nautical-mile voyages (cost data from Bloomberg, shipping distances from sea-distances.com). Average distance to Japan is calculated from the following regas facilities/ports: Chita, Hagashi Ogishima, Himeji, Kagoshima, Mizushima, Nagasaki, Ogishima, Oita, Sakai, Sakaide, Senboku, Tobata, Wakayama, Yokkaichi. Average distance to China is calculated from the following regas facilities/ports: Dalian, Guangzhou, Qingdao, Shanghai, Tianjin, Hong Kong.

It is important to remember that the LNG supply chain still requires pipelines to deliver natural gas to and from LNG terminals; these add additional costs for liquefaction and regasification. Regasification typically costs between $\$ 0.29 / \mathrm{GJ}$ and $\$ 1.90 / \mathrm{GJ}$ (\$0.30/MMBTU to $\$ 2.00 / \mathrm{MMBTU}$ ), and liquefaction is more expensive, ranging from $\$ 2.81 / \mathrm{GJ}$ to $\$ 5.04 / \mathrm{GJ}$ (\$2.96/MMBTU to $\$ 5.30 / \mathrm{MMBTU}){ }^{201}$ The cost for regasification occurs primarily because of capacity utilization and, to some extent, the cost of the facility, since these costs are amortized to the product. The regasification costs vary since the nature of regasification normally will mean installing more capacity than is initially required, with ramp-up occurring as the demand for natural gas develops. This causes the unit costs to be high when the utilization is low and costs decline as the throughput increases. Facility costs for liquefaction will vary according to when the facility was built, where the facility was built, and the scope of the project. Older facilities have less cost to amortize because their legacy costs are lower than the costs of building new facilities. The location matters, as costs for building in remote areas are higher than where the construction infrastructure is developed, such as on the U.S. Gulf Coast. Project scope impacts the cost for liquefaction, because of differences for individual projects in project scope ${ }^{202}$ such as whether a project is greenfield or brownfield, or whether cross-country pipelines and other elements are included.

Despite the low costs of shipping, the transport of natural gas in the form of LNG via tankers introduces new challenges. Environmental concerns regarding possible spills, as well as aggregate well-to-wheel emissions, are commonly cited points of contention. Further, the regasification of LNG during transportation - called boil-off - erodes margins. Tankers can expect boil-off of 0.1 to 0.15 per cent of full cargo content each day during a voyage, ${ }^{203}$ though some is recaptured and used as fuel in ships equipped with gas-turbine generators. LNG

${ }^{201}$ PFC Global Energy cites \$0.40/MMBTU as the low end of its range, with \$2.00/MMBTU as the high end (PFC Global Energy, LNG Supply and Demand Study, May 2013, 7). Data from Poten \& Partners, via Bloomberg (ticker: POTN), has the range of $\$ 0.30 / \mathrm{MMBTU}$ to $\$ 0.40 / \mathrm{MMBTU}$. Estimates of liquefaction costs come from Table 6.5.

${ }^{202}$ Reported costs for liquefaction may vary due to the project scope that the reporter includes. Differences in project scope include whether elements such as the following are included: wharfs and jetties, LNG storage, natural gas pipelines, other infrastructure (roads, housing, etc.), project interest, and owner's cost.

${ }^{203}$ M. Hasan, I. Karimi and H. Alfadala, “Optimizing Compressor Operations in an LNG Plant," Proceedings of the First Annual Gas Processing Symposium, 2009. 
tankers also typically retain a portion (often five per cent) of the LNG product, even after unloading the majority of it, which is called the heel. The heel is used to maintain the temperature of the storage tanks in order to avoid flash boil-off during tank loading. ${ }^{204}$

\subsubsection{COST ASSUMPTIONS FOR CANADIAN PRODUCTION}

Canadian natural gas prices are derived from a common set of components shared throughout the industry. Conventional gas resources have been in decline over the last decade, but are being replaced by new production from unconventional sources, largely based on horizontal drilling and hydraulic fracturing. They reflect a combination of well costs and stimulation costs, and are subject to distance and transportation surcharges, defining the wellhead price before transshipment to liquefaction facilities. The presence of natural gas liquids affects the market value of the gas stream, depending on heat content, corrosive materials and other contaminants.

This report develops pricing and market penetration estimates based primarily on dry gas, assumed to have a normal range of heat content, in order to have comparable values that would be available from competing nations. However, the market for both liquids-rich gas (NGLs) and other derivatives such as liquefied petroleum gas (LPG) for boosting heat values at the destination ports is robust and may constitute additional or parallel market opportunities for Canadian producers.

FIGURE 6.8: NOMINAL SUPPLY COSTS BY WELL TYPE AND PROVINCE (CANADIAN DOLLARS)

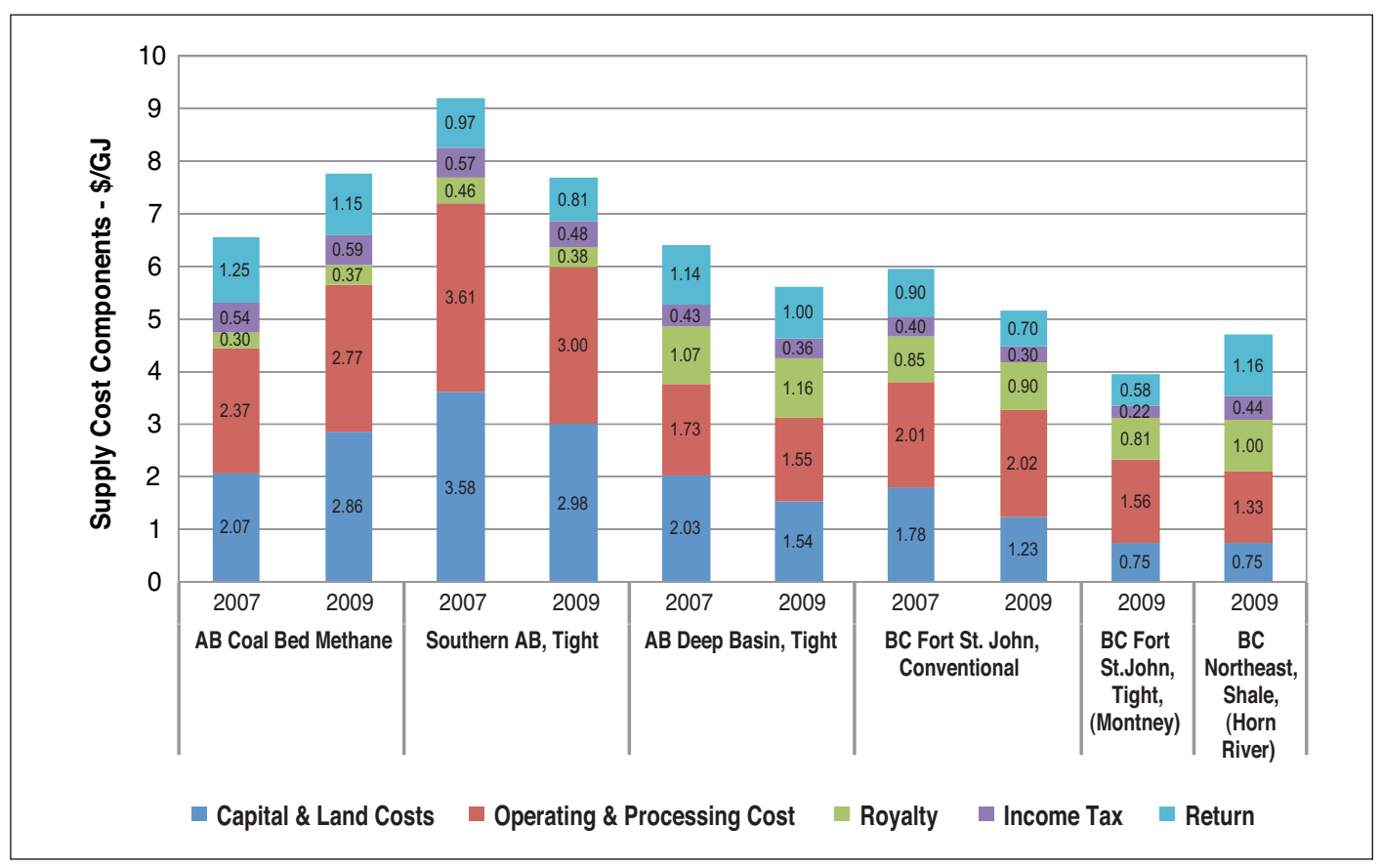

Source: NEB, Natural Gas Supply Costs in Western Canada in 2009, Energy Briefing Note, November 2010, 11, http://www.neb-one.gc.ca/clfnsi/rnrgynfmtn/nrgyrprt/ntrlgs/ntrlgsspplcstwstrncnd2009_2010/ntrlgsspplcstwstrncnd2009-eng.html.

${ }^{204}$ ibid. 
In this section, we briefly establish common production costs and assumptions by segment of the industry, primarily to support this platform of comparison with other shipping nations or provinces within Canada with competing reserves of natural gas. The NEB publishes estimates of supply costs by region including wellhead and transfer costs. Figure 6.8 above illustrates the range by nature of cost, province and well type in the most recent reported values as of 2009. The supply cost defined by the NEB is "the minimum price required to produce a gigajoule (GJ) of natural gas, covering all costs, royalties, and taxes and includes a 15 per cent rate of return (ROR) after tax." 205 Table 6.5 gives supply costs from B.C. sources in 2012 U.S. dollars. The best-case scenario for supply costs based on the NEB data is $\$ 3.72 / \mathrm{GJ}$ ( $\$ 3.93 / \mathrm{MMBTU})$, and the worst case is $\$ 17.56 / \mathrm{GJ}$ ( $\$ 18.53 / \mathrm{MMBTU}$ ). It is possible that production costs have increased since 2012, though depreciation of the Canadian dollar will make Canadian supplies less costly.

TABLE 6.5: SUPPLY COSTS BY WELL TYPE IN B.C. (2012 U.S. DOLLARS)

\begin{tabular}{|c|c|c|c|c|c|c|}
\hline \multirow[t]{3}{*}{ Area } & \multirow[t]{3}{*}{ Resource Type } & \multirow[t]{3}{*}{ Resource Group } & \multirow{2}{*}{\multicolumn{2}{|c|}{$\begin{array}{c}100 \% \text { Success Rate } \\
\text { (un-risked) }\end{array}$}} & \multirow{2}{*}{\multicolumn{2}{|c|}{$\begin{array}{c}\text { Historical Success } \\
\text { Rates (risked) } \\
\text { Supply Cost }\end{array}$}} \\
\hline & & & & & & \\
\hline & & & $\$ / G J$ & \$/MMBTU & $\$ / G J$ & \$/MMBTU \\
\hline B.C. Deep Basin & Conventional & Lower Triassic & 5.71 & 6.02 & 5.78 & 6.10 \\
\hline B.C. Deep Basin & Tight & Mannville & 6.60 & 6.96 & 6.63 & 6.99 \\
\hline B.C. Deep Basin & Tight & Lower Triassic & 7.94 & 8.38 & 7.94 & 8.38 \\
\hline Fort St. John & Conventional & Mannville & 9.56 & 10.09 & 9.66 & 10.19 \\
\hline Fort St. John & Conventional & Triassic & 4.88 & 5.15 & 4.89 & 5.16 \\
\hline Fort St. John & Tight & Triassic & 3.72 & 3.93 & 3.72 & 3.93 \\
\hline Northeast B.C. & Tight & Upper Devonian & 17.32 & 18.28 & 17.56 & 18.53 \\
\hline B.C. Foothills & Conventional & Colorado and Mannville & 8.85 & 9.34 & 8.95 & 9.44 \\
\hline Production-weighted average & & & 6.21 & 6.56 & 6.26 & 6.60 \\
\hline
\end{tabular}

Notes: Deflated from 2009 Canadian dollar using CANSIM Table 384-0038. Average exchange rate between Canadian and U.S. dollars in 2012 is parity.

Source: NEB, Natural Gas Supply Costs in Western Canada in 2009, Energy Briefing Note, November 2010, Table 1 , http://www.neb-one.gc.ca/clfnsi/rnrgynfmtn/nrgyrprt/ntrlgs/ntrlgsspplcstwstrncnd2009_2010/ntrlgsspplcstwstrncnd2009-eng.html.

LNG export plants are extremely capital intensive. As illustrated in Figure 3.12, liquefaction plant capital costs in U.S. dollars per tonne of annual capacity (a standard industry metric) are high relative to pre-2010 construction. The cost of projects in Australia, where most of the plants currently under construction are located, have experienced significant cost overruns. In a February 2011 report, Wood Mackenzie adopted a "High Capex" sensitivity involving an increase of 25 per cent in its base-case capital cost estimates for Australian projects in response to upward cost pressures. With this cost increase, the break-even delivered-LNG prices for eight Australian LNG export projects increased from a range of US\$6.65 to US\$12.20/MMBTU to a range of US\$9.42 to US\$14.31/MMBTU. ${ }^{206}$ In light of continued cost pressures since February 2011, Wood Mackenzie's high cost-sensitivity may prove to have been optimistic.

\footnotetext{
${ }^{205}$ NEB, Natural Gas Supply Costs in Western Canada in 2009, Energy Briefing Note, November 2010, http://www.neb-one.gc.ca/clfnsi/rnrgynfmtn/nrgyrprt/ntrlgs/ntrlgsspplcstwstrncnd2009_2010/ntrlgsspplcstwstrncnd2009-eng.html.

${ }^{206}$ Wood Mackenzie, “Might Rising Costs in Australia Propel North America LNG Exports?” (February 2011).
} 
International suppliers provide the equipment components for all of the liquefaction plants in the world. However, LNG export-plant costs vary significantly from country to country, and between locations within the same country, depending on: the remoteness of the project site; the infrastructure in place; local geotechnical and marine conditions; environmental regulations; climatic conditions; the availability, cost and productivity of the labour force; and currency exchange rates, among other things. These factors will lead to upward pressure on the cost of constructing liquefaction plants in Canada. At this point, it is difficult to estimate what liquefaction plants will cost in Canada; nevertheless, several authors have attempted to do so.

Wood Mackenzie, in its February 2011 report, assumed that the remoteness of Canadian sites, coupled with the potential for resource and labour competition with other sectors, could contribute to high development costs. Wood Mackenzie assumed a capital cost range of US\$900 to US\$1,200/TPA for Canadian projects. A more recent report by Macquarie Private Wealth, assumed a capital cost of US\$1,200/TPA, which is consistent with the upper end of Wood Mackenzie's range. ${ }^{207}$ In December 2012, NERA Economic Consulting published an estimate of $\$ 1,145 /$ TPA for Canadian liquefaction plant costs. ${ }^{208}$

Canadian LNG projects are in competition with export projects in the U.S., most of which are brownfield conversions of LNG import terminals. Several U.S. projects are at an advanced stage of the development process. One project, Cheniere's Sabine Pass LNG, is already under construction. Based on published cost information, it is clear that brownfield projects on the U.S. Gulf Coast (USGC) have a significant cost advantage over Canadian greenfield projects. Contracts awarded by Cheniere for its 18 MMTPA Sabine Pass project suggest brownfield liquefaction capital costs of about \$622/TPA for the first two 4.5 MMTPA trains, and \$556/TPA for the third and fourth 4.5 MMTPA trains, for an average of \$588/TPA for the four trains. ${ }^{209}$

It should be noted that Cheniere's capital costs are higher than assumed by NERA (US\$544/TPA) in December 2012, and by Wood Mackenzie in February 2011 ("High Capex" of US\$500/TPA), suggesting that projects in the U.S. are not immune to all of the factors driving costs higher in Australia. Cheniere will recoup its LNG plant capital and operating costs through a liquefaction processing fee between US\$2.13/GJ and $\$ 2.84 / \mathrm{GJ}$

(US\$2.25/MMBTU to US\$3.00/MMBTU), plus 15 per cent of the Henry Hub price (to cover the cost of fuel and plant losses). ${ }^{210}$

Liquefaction-plant costs are a major component of the LNG value-chain project costs for delivering LNG to markets. In addition, there are upstream costs, pipeline transmission costs (if LNG plants are distant from gas resources), and LNG shipping costs. Upstream costs (wellhead gas prices) will vary by field and over time. Table 6.6 summarizes the views of Wood Mackenzie, Macquarie and NERA regarding Canadian and USGC LNG value-chain project costs downstream of the wellhead, and negotiated liquefaction charges for Cheniere's Sabine Pass LNG project.

\footnotetext{
${ }^{207}$ Macquarie Private Wealth, "Canadian LNG: The race to the coast" (September 10, 2012).

${ }^{208}$ NERA, "Macroeconomic Impacts of LNG Exports from the United States" (December 3, 2012).

${ }^{209}$ Cheniere Energy Partners LP, “Cheniere Issues Notice to Proceed (“NTP”) for Construction of First Two Liquefaction Trains", press release, August 9, 2012; and Cheniere Energy Partners, "Cheniere Partners Enters into Lump Sum Turnkey Contract with Bechtel for Trains 3 and 4 at Sabine Pass Liquefaction," press release, December 21, 2012 .

${ }^{210}$ Cheniere Energy Inc., Corporate Presentation for Sabine Pass LNG, September 11, 2013.
} 
TABLE 6.6: VIEWS OF VALUE-CHAIN PROJECT COSTS (\$US/MMBTU)

\begin{tabular}{|c|c|c|c|c|c|c|c|}
\hline \multirow{3}{*}{$\begin{array}{l}\text { Costs per MMBTU } \\
\text { (U.S. Dollars) }\end{array}$} & \multicolumn{3}{|c|}{ U.S. Gulf Coast (Brownfield) } & \multicolumn{4}{|c|}{ Western Canada (Greenfield } \\
\hline & \multirow{2}{*}{$\begin{array}{l}\text { Wood } \\
\text { Mackenzie } \\
\text { (2011) }\end{array}$} & \multirow{2}{*}{$\begin{array}{l}\text { NERA } \\
(2012)\end{array}$} & \multirow{2}{*}{$\begin{array}{l}\text { Cheniere Sabine } \\
\text { Pass (2013) }\end{array}$} & \multirow{2}{*}{$\begin{array}{l}\text { Wood } \\
\text { Mackenzie } \\
\text { (2011) }\end{array}$} & \multicolumn{2}{|c|}{ Macquarie (2012) } & \multirow{2}{*}{$\begin{array}{c}\text { NERA } \\
\text { (2012) }\end{array}$} \\
\hline & & & & & Montney & Horn River & \\
\hline $\begin{array}{l}\text { Pipeline Toll from } \\
\text { Wellhead/Upstream } \\
\text { to LNG Export Plant }\end{array}$ & - & $\$ 1.00$ & - & $\$ 1.40$ & $\$ 0.80$ & $\$ 1.00$ & $\$ 0.70$ \\
\hline $\begin{array}{l}\text { Fixed } \\
\text { Liquefaction Costs } \\
\text { (i.e., Capital Cost } \\
\text { Recovery) }\end{array}$ & $\begin{array}{l}\$ 2.18 \\
\text { Based on high- } \\
\text { capex case of } \\
\$ 500 / \text { TPA }\end{array}$ & $\begin{array}{l}\$ 1.61 \\
\text { Based on capex } \\
\text { of } \$ 544 / \text { TPA }\end{array}$ & $\begin{array}{l}\$ 2.25 \text { - } \$ 3.00 \\
\text { Liquefaction fees } \\
\text { range from } \\
\$ 2.25 / \text { MMBTU to } \\
\$ 3.00 / \text { MMBTU }\end{array}$ & $\begin{array}{l}\$ 4.07 \\
\text { Based on high- } \\
\text { capex case of } \\
\$ 1,200 / \text { TPA }\end{array}$ & \multicolumn{2}{|c|}{$\begin{array}{l}\text { Based on capex of } \\
\$ 1,200 / \text { TPA }\end{array}$} & $\begin{array}{l}\$ 3.39 \\
\text { Based on capex } \\
\text { of } \$ 1,145 / \text { TPA }\end{array}$ \\
\hline $\begin{array}{l}\text { Variable } \\
\text { Liquefaction Costs }\end{array}$ & $\begin{array}{l}\$ 0.78 \\
10 \% \text { plant losses } \\
\text { (assumed Henry } \\
\text { Hub at } \\
\$ 7.00 / \text { MMBTU) }\end{array}$ & $\begin{array}{l}\$ 0.53 \\
9 \% \text { of wellhead } \\
\text { price (assumed } \\
\$ 3.83 / \text { MMBTU), } \\
\text { plus operating } \\
\text { cost of } \\
\$ 0.16 / \text { MMBTU }\end{array}$ & $\begin{array}{l}\$ 1.05 \\
15 \% \text { times Henry } \\
\text { Hub (assuming } \\
\text { Henry Hub at } \\
\$ 7.00 / \text { MMBTU) }\end{array}$ & $\begin{array}{l}\$ 0.56 \\
10 \% \text { plant } \\
\text { losses (assumed } \\
\text { AECO at } \\
\$ 6.00 / \text { MMBTU) }\end{array}$ & \multicolumn{2}{|c|}{$\begin{array}{l}\text { Operating costs ( } \$ 1.00) \text {, } \\
\text { maintenance capex } \\
(\$ 0.10) \text {, plus } G \& A(\$ 0.10) \\
\text { included in } \$ 5.30 \\
\text { breakeven cost in } \\
\text { Macquarie report }\end{array}$} & $\begin{array}{l}\$ 0.49 \\
9 \% \text { of wellhead } \\
\text { price (assumed } \\
\$ 3.72 / \text { MMBTU), } \\
\text { plus operating } \\
\text { cost of } \\
\$ 0.16 / \text { MMBTU }\end{array}$ \\
\hline $\begin{array}{l}\text { Total } \\
\text { Liquefaction Costs }\end{array}$ & $\$ 2.96$ & $\$ 2.14$ & $\$ 3.30-\$ 4.05$ & $\$ 4.63$ & $\$ 5.30$ & $\$ 5.30$ & $\$ 3.88$ \\
\hline Shipping & $\begin{array}{l}\mathbf{\$ 1 . 5 8} \\
\text { To Japan via } \\
\text { Panama Canal }\end{array}$ & $\begin{array}{l}\mathbf{\$ 2 . 5 4} \\
\text { To Japan via } \\
\text { Panama Canal }\end{array}$ & & $\begin{array}{l}\mathbf{\$ 0 . 7 5} \\
\text { To Japan }\end{array}$ & $\begin{array}{l}\mathbf{\$ 0 . 8 0} \\
\text { Implied des }\end{array}$ & $\begin{array}{l}\mathbf{\$ 0 . 8 0} \\
\text { nation is Japan }\end{array}$ & $\begin{array}{l}\text { \$1.23 } \\
\text { To Japan }\end{array}$ \\
\hline
\end{tabular}

Notes: This table does not include every cost associated with the gas-to-LNG-to-gas value chain, but it does provide an indication of the various estimates for each component of costs.

Sources: Cheniere Energy Inc., Corporate Presentation for Sabine Pass LNG, September 11, 2013; NERA, "Macroeconomic Impacts of LNG Exports from the United States" (December 3, 2012); Macquarie Private Wealth, "Canadian LNG: The race to the coast" (September 10, 2012); Wood Mackenzie, "Might Rising Costs in Australia Propel North America LNG Exports?" (February 2011).

\subsubsection{CANADIAN COSTS OF DELIVERED ENERGY}

We have assumed the delivered cost of energy will reflect a range of costs as shown in published literature. They are commonly divided into three key sections: wellhead costs and transport to liquefaction facilities; liquefaction and loading; and shipping to the final destination port. We use dry gas as a reference point; gas with liquids commands a higher price currently, but market circumstances for that commodity currently are in a state of flux and consequently we cannot estimate the role of NGLs in a future Asia-Pacific market.

The range of estimates for wellhead costs have led us to use the figures published by the $\mathrm{NEB}^{211}$ as a starting point that is in a range of those costs published by private companies or applicants. $^{212}$

\footnotetext{
${ }^{211}$ See Figure 6.8. Source: National Energy Board, Natural Gas Supply Costs in Western Canada in 2009, 11.

${ }^{212}$ See: Macquarie Private Wealth, "Canadian LNG”; and NERA, "Macroeconomic Impacts."
} 
TABLE 6.7: CANADIAN DELIVERED COST COMPONENTS (\$US)

\begin{tabular}{|l|cc|cc|}
\hline \multirow{2}{*}{ Component } & \multicolumn{2}{|c|}{ Cost Range (\$/G) } & \multicolumn{2}{c|}{ Cost Range (\$/MMBTU) } \\
\cline { 2 - 5 } Well Supply Cost & Low & High & Low & High \\
Pipeline toll & 3.72 & 9.66 & 3.93 & 10.19 \\
Liquefaction & 1.42 & 2.61 & 1.50 & 2.75 \\
Shipping & 0.46 & 1.14 & 0.49 & 1.20 \\
\hline Total & 1.05 & 1.36 & 1.11 & 1.43 \\
\hline
\end{tabular}

The delivered cost of Canadian gas, before a risk premium, taxes, capital-cost recovery, or required rate of return on investment, ranges from $\$ 6.65 / \mathrm{GJ}$ (\$7.03/MMBTU) to $\$ 14.77 / \mathrm{GJ}$ (\$15.57/MMBTU). The delivered cost of Canadian gas is unlikely to average below US $\$ 10.40$ per GJ (US\$11 per MMBTU) in the low-cost case when capital recovery and a risk premium on the liquefaction facility is applied (based on suggested capital-cost recovery charges in Table 6.6). Table 6.8 shows before-tax rates of return for a range of capital costs and revenue streams. We see that low-cost facilities have a high rate of return even at low margins between the landed price and delivery costs, whereas a margin of $\$ 9.50 / \mathrm{MMBTU}$ is required before the most expensive facility reaches a before-tax rate of return above 15 per cent.

TABLE 6.8: BEFORE-TAX RATE OF RETURN CALCULATIONS

\begin{tabular}{|c|c|c|c|c|c|c|r|r|}
\hline \multicolumn{2}{|c|}{ Margin (landed price less variable costs) } & \multicolumn{7}{|c|}{ Capital expenditure per tonne } \\
\hline $\mathbf{\$}$ /MMBTU & $\mathbf{\$} / \mathbf{G J}$ & $\mathbf{\$} / \mathbf{M M T}$ & $\mathbf{\$ 5 0 0}$ & $\mathbf{\$ 1 , 0 0 0}$ & $\mathbf{\$ 1 , 5 0 0}$ & $\mathbf{\$ 2 , 0 0 0}$ & $\mathbf{\$ 2 , 5 0 0}$ & $\mathbf{\$ 3 , 0 0 0}$ \\
\hline 3.00 & 2.84 & $154,800,000$ & $30.82 \%$ & $14.44 \%$ & $8.18 \%$ & $4.58 \%$ & $2.13 \%$ & $0.30 \%$ \\
3.50 & 3.32 & $180,600,000$ & $36.04 \%$ & $17.32 \%$ & $10.37 \%$ & $6.44 \%$ & $3.79 \%$ & $1.84 \%$ \\
4.00 & 3.79 & $206,400,000$ & $41.24 \%$ & $20.11 \%$ & $12.44 \%$ & $8.18 \%$ & $5.34 \%$ & $3.25 \%$ \\
4.50 & 4.27 & $232,200,000$ & $46.42 \%$ & $22.84 \%$ & $14.44 \%$ & $9.83 \%$ & $6.79 \%$ & $4.58 \%$ \\
5.00 & 4.74 & $258,000,000$ & $51.59 \%$ & $25.53 \%$ & $16.37 \%$ & $11.42 \%$ & $8.18 \%$ & $5.83 \%$ \\
5.50 & 5.21 & $283,800,000$ & $56.75 \%$ & $28.18 \%$ & $18.26 \%$ & $12.95 \%$ & $9.51 \%$ & $7.03 \%$ \\
6.00 & 5.69 & $309,600,000$ & $61.92 \%$ & $30.82 \%$ & $20.11 \%$ & $14.44 \%$ & $10.79 \%$ & $8.18 \%$ \\
6.50 & 6.16 & $335,400,000$ & $67.08 \%$ & $33.44 \%$ & $21.94 \%$ & $15.89 \%$ & $12.03 \%$ & $9.29 \%$ \\
7.00 & 6.63 & $361,200,000$ & $72.24 \%$ & $36.04 \%$ & $23.74 \%$ & $17.32 \%$ & $13.25 \%$ & $10.37 \%$ \\
7.50 & 7.11 & $387,000,000$ & $77.40 \%$ & $38.64 \%$ & $25.53 \%$ & $18.73 \%$ & $14.44 \%$ & $11.42 \%$ \\
8.00 & 7.58 & $412,800,000$ & $82.56 \%$ & $41.24 \%$ & $27.30 \%$ & $20.11 \%$ & $15.60 \%$ & $12.44 \%$ \\
8.50 & 8.06 & $438,600,000$ & $87.72 \%$ & $43.83 \%$ & $29.06 \%$ & $21.48 \%$ & $16.75 \%$ & $13.45 \%$ \\
9.00 & 8.53 & $464,400,000$ & $92.88 \%$ & $46.42 \%$ & $30.82 \%$ & $22.84 \%$ & $17.88 \%$ & $14.44 \%$ \\
9.50 & 9.00 & $490,200,000$ & $98.04 \%$ & $49.00 \%$ & $32.56 \%$ & $24.19 \%$ & $19.00 \%$ & $15.41 \%$ \\
10.00 & 9.48 & $516,000,000$ & $103.20 \%$ & $51.59 \%$ & $34.31 \%$ & $25.53 \%$ & $20.11 \%$ & $16.37 \%$ \\
10.50 & 9.95 & $541,800,000$ & $108.36 \%$ & $54.17 \%$ & $36.04 \%$ & $26.86 \%$ & $21.21 \%$ & $17.32 \%$ \\
11.00 & 10.43 & $567,600,000$ & $113.52 \%$ & $56.75 \%$ & $37.78 \%$ & $28.18 \%$ & $22.30 \%$ & $18.26 \%$ \\
\hline
\end{tabular}

Notes: Assumes constant revenue stream for 20 years, based on a two-train, 9 MMTPA facility operating at full capacity.

Previous prices for delivered gas in the Asia-Pacific region were averaging above US $\$ 15.60$ per GJ (US\$16.50 per MMBTU), a function of the JCC pricing convention based on a basket of oil products delivered in Japan. Japanese demand for LNG has underpinned a strong demand component of the market; these prices could be expected to decline if a new pricing standard is developed, if substantially larger supplies of LNG were to emerge in the marketplace from the U.S. or Qatar in the near term or even if the nuclear facilities in Japan 
were partially reinstated. Given that Japan's spot LNG price peaked at approximately $\$ 17 / \mathrm{GJ}$ and has traded as low as $\$ 13.625 / \mathrm{MMBTU},{ }^{213}$ the projects are potentially still economically feasible, but this will depend heavily on the supply cost of natural gas.

The short-term increase in demand associated with the loss of Japanese nuclear capacity led to a substantial and attractive price differential between the calculated cost of production for Canadian natural gas, if it could be shipped to the Asia-Pacific market, and the delivered port price. As more countries build liquefaction capacity - especially those producers in the Gulf Coast region - and begin to deliver into this market, there will be a tendency of this differential to close. It is not possible to estimate the differential over time, but estimates in the marketplace suggest long-term convergence between Henry Hub, Japan and the U.K.'s Net Balancing Point prices. ${ }^{214}$ Any reduction of the differential impacts Canadian producers; ultimately this will be borne by producers, who must decide if residual values will support long-term contracts. If Asian prices stabilize at $\$ 13 / \mathrm{MMBTU}$, the best-case cost scenario yields a margin of $\$ 6.50 / \mathrm{MMBTU}$; higher-cost supplies will correspondingly decrease the economic feasibility of potential facilities.

\section{RISK AND LNG MARKETS}

This paper deals with markets for Canadian natural gas resources; the development of which inherently implies risk, both public and private. While we do not intend to re-invent businesstextbook treatment of this topic, it is worth noting that markets and development in this energy sector are unique and pose inherent challenges for all parties involved.

The actors in this market are: investors; the public in the form of decision-makers and regulators; the public in the form of landowners and stakeholders at the various points of project development; and the project developers and their finance partners. We do not attempt to directly portray risk for any given party, since that would involve unique facts and assumptions that are dynamic and subject to change in any case. What we can do is to describe the categories of risk that might curtail or even obstruct the success of this market, assuming that it is the collective will of the Canadian public that it go forward.

Risk and uncertainty in markets such as these are expected, since without them there is no incentive for returns to capital. In this case, risks and uncertainty are magnified by recent changes in policy prescriptions and environmental standards, competitive entry into the market by other natural-gas-rich nations, price uncertainty and shifts in demand preference. For purposes of this paper, we have assumed that all the normal risk categories (see Table 7.1 following) can be managed and have assigned costs that are associated with "manageable" risk. In this vein, delays in market access, or project denial can represent insurmountable costs or actions and represent the potential loss of sunk cost or access to markets. The revenues that would flow from project completion are not considered in this analysis.

\footnotetext{
${ }^{213}$ Eriko Amaha, "Platts LNG JKM for July starts trading at \$13.625/MMBtu amid weak demand," Platts, May 16, 2014, http://www.platts.com/latest-news/natural-gas/asia/platts-lng-jkm-for-july-starts-trading-at-13625mmbtu26790468?wt.mc_id=energybulletin_oilgaspetchemshipping_campaign_051614\&wt.tsrc=eloqua\&elq=5ad50112ec57 41c6ba5c65776eeead8f\&elqcampaignid $=5446$.

${ }^{214}$ James Melvin, “U.S. LNG exports likely capped at 6 Bcf/d due to price convergence: analyst,” Platts, May 13, 2014, http://www.platts.com/latest-news/natural-gas/washington/us-lng-exports-likely-capped-at-6-bcfd-due-to-21616591.
} 
Although they are capital intensive, LNG projects represent relatively low risk ${ }^{215}$ for investors, since they are typically developed based on long-term contracts for supply and demand. Of course, the amount of risk to which buyers and sellers are exposed depends on the formula used and the base price (Henry Hub versus oil-linked prices) as described in Section 2.1. The nature of these long-term contracts supports investor confidence, given the amount of capital necessary and the time commitment for development and use, typically measured in decades. The strongest source of demand is from power generation, which features stable and predictable characteristics. Future changes in this demand may emerge in the form of alternative generating technologies, or changes in building design or use patterns that can shift domestic heating loads.

Natural gas prices in particular have proven volatile over the last several decades, a reflection of seasonal shifts in demand, changes in delivery capacity and storage, and declines in production from conventional fields. The advent of new drilling techniques and the identification and access to unconventional fields worldwide has dramatically changed this dynamic, resulting in floors rather than ceilings in price, and much more stable supply predictions.

The result has been increased interest in natural gas export potential where neighbouring countries have net demand increases over domestic capacity, and to countries with little domestic capability and access to tidewater deliveries. The obvious current attraction for exporting countries is a clear differential between production costs and the delivery port price. The consequence is a unique suite of risks for an industry that historically has only expanded with high confidence in growth in client-country demand and reliance on stable, renewable, long-term contracts.

It is reasonable to view the existing LNG industry as relatively low risk given the stability offered by existing long-term contracts. There is more uncertainty and corresponding risk for the developing industry players, especially those operating from Canada, where the natural gas industry is mature but the LNG industry is not. This is particularly true when dealing with unconventional natural gas resources where production lifespans can be more limited than in traditional vertical-well systems. Here, production from shale and tight-sand formations can experience a more rapid production-decline rate than with conventional development, suggesting more frequent re-drilling and stimulation on an annual basis and, ultimately, a steep rate of decline as reserves are depleted.

In sum then, the nature of risk involved is centred in five key areas:

1. Permits and permission, including rights of way, port development and access to adequate electricity for liquefaction operations;

2. Political risk and public support for the industry;

3. The evolution of long-term contracts to include developers as counterparties and shifts in demand characteristics in some receiving countries;

\footnotetext{
215 "Low risk" is a relative term and is dependent on individual contract terms or price points, such as the difference between JCC or Henry Hub pricing, which may change dramatically during the contract period. As a consequence, each arrangement is "at risk," although once established, these contracts represent predictable supply and delivery commitments.
} 
4. Potential surpluses in supply, as more and more countries take advantage of cheaper conventional and unconventional gas plays ${ }^{216}$ and LNG facility developments;

5. Unpredictable shifts in carbon pricing and environmental standards.

Permission to develop energy facilities at every level becomes more uncertain in developed countries each year. The combination of increased standards, public scrutiny and safety and environmental indemnification has translated into higher costs, longer processing times and more uncertainty about the nature of the ultimate project approval (capacity). Since every LNG project is interlinked, from field development to processing and transfer prior to shipment, the same type of risk is affecting all the support systems that must be in place for an LNG facility to operate. As well, in Canada, the unique relationship of First Nation land tenure, ownership and environmental standards must be taken into account, although these relationships are imperfectly developed at present. The number and scope of proposed projects, with the requisite pipelines and gas-well development, has and will raise concerns among First Nations whose lands are affected by development. This has the potential to be a major obstacle to the development of an LNG industry, and will require co-operation by all parties to appropriately address concerns.

We translate this risk characteristic in two ways: project and delivered product cost, and time needed to actually begin operations. In the LNG market, years of uncertainty regarding North American gas supplies have shifted the potential near-term advantage to other Asia-Pacific developers. There is a current attraction represented by a strong price premium at hubs such as those in Japan. Over time however, there is a strong possibility of market saturation and a compression of the existing price differentials. The collapse of this price differential could occur in a relatively short period of time, depending on the speed at which new supplies such as those from the U.S. Gulf Coast reach the market

The most difficult risk to evaluate in this context is that of political and public policy, coupled with public opinion and reaction to project design. An example of this is B.C.'s proposed LNG tax, which adds cost to projects that are potentially marginal, and uncertainty due to the fact that little is known about its form. This sort of risk is unstable at the moment, and yet will contribute both to the cost of financing and the ability to access the market in a timely fashion. The associated risk categories here are: the designation and approval of future utility or pipeline rights of way; environmental regulations on fuels and the enforcement of standards; costs of construction and labour availability; and port construction and marine-safety standards.

Ultimately the market will determine levels of development by assessing risk premiums, which will in turn dictate the required rates of return for investors. Much of the confidence of investors will reflect the risk they perceive regarding the stability and reliability of the public policy regime. Since, in financial markets, risk and uncertainty are closely related, the more predictable the outcome to the market, the lower the risk. The policy issues and uncertainty surrounding them that will affect investors' decisions include: whether to allow LNG exports and how much; environmental policy (emissions, waste disposal and reclamation); the fiscal regime for royalties on gas produced; taxation policy (both corporate and LNG plant-specific); as well as pipeline approval, construction timing, and tolls.

\footnotetext{
${ }^{216}$ Substantial discoveries offshore in Mozambique and Tanzania are conventional, and projects in Papua New Guinea are conventional, and there are still a lot of conventional supplies to come from Australia, Russia and the Middle East. Unconventional natural gas is not always competitive in price. To date, it is only economical where the industry has developed the technology and support industry to do it on a manufacturing scale - i.e., North America and Eastern Australia.
} 
TABLE 7.1: ILLUSTRATIVE RISK AND UNCERTAINTY IN NATURAL GAS MARKETS SERVED BY LNG

\begin{tabular}{|c|c|c|c|c|c|}
\hline Phase & $\begin{array}{c}\text { Uncertainty } \\
\text { characteristics }\end{array}$ & Nature of risk & $\begin{array}{l}\text { Factor influencing } \\
\text { uncertainty }\end{array}$ & $\begin{array}{c}\text { Risk } \\
\text { borne by }\end{array}$ & $\begin{array}{l}\text { Outcome } \\
\text { or failure }\end{array}$ \\
\hline Planning & Low & $\begin{array}{l}\text { Size and design } \\
\text { mismatch }\end{array}$ & $\begin{array}{l}\text { Mis-estimation of market } \\
\text { fundamentals; } \\
\text { misunderstanding of regulatory } \\
\text { process }\end{array}$ & Developer & $\begin{array}{l}\text { Success leads to } \\
\text { project submittal }\end{array}$ \\
\hline $\begin{array}{l}\text { Permits and } \\
\text { Permission } \\
\text { (Developer) }\end{array}$ & $\begin{array}{l}\text { Moderate } \\
\text { to High }\end{array}$ & $\begin{array}{l}\text { Project-denial mitigation- } \\
\text { cost; length of time }\end{array}$ & Policy and regulatory standards & Developer & $\begin{array}{l}\text { Project denied or } \\
\text { too expensive to } \\
\text { finance }\end{array}$ \\
\hline $\begin{array}{l}\text { Permits and } \\
\text { Permission } \\
\text { (Public) }\end{array}$ & $\begin{array}{l}\text { Low to } \\
\text { Moderate }\end{array}$ & $\begin{array}{l}\text { Failure to adequately } \\
\text { identify important } \\
\text { standards and issues }\end{array}$ & $\begin{array}{l}\text { Weak policies; inconsistent or } \\
\text { restrictive regulatory standards; } \\
\text { failure to include some } \\
\text { stakeholders }\end{array}$ & Public & $\begin{array}{l}\text { Environmental } \\
\text { damage; need for } \\
\text { public funding; loss } \\
\text { of support }\end{array}$ \\
\hline $\begin{array}{l}\text { Development } \\
\text { and Mitigation }\end{array}$ & $\begin{array}{l}\text { Moderate } \\
\text { to High }\end{array}$ & $\begin{array}{l}\text { Construction cost; } \\
\text { unexpected terrain }\end{array}$ & $\begin{array}{l}\text { Inadequate assessment; } \\
\text { control of construction process; } \\
\text { additional mitigation costs }\end{array}$ & Developer & $\begin{array}{l}\text { Project } \\
\text { uncompetitive }\end{array}$ \\
\hline Operations & Moderate & $\begin{array}{l}\text { Not competitive in } \\
\text { marketplace; loss of } \\
\text { supply }\end{array}$ & $\begin{array}{l}\text { Competition or supply- } \\
\text { replacement costs }\end{array}$ & Developer & $\begin{array}{l}\text { Stranded assets; } \\
\text { diverted capital } \\
\text { resources }\end{array}$ \\
\hline $\begin{array}{l}\text { Environmental } \\
\text { Policy and } \\
\text { Assessment }\end{array}$ & High & $\begin{array}{l}\text { Changing standards and } \\
\text { policies }\end{array}$ & $\begin{array}{l}\text { Government, legislative and } \\
\text { regulatory uncertainty }\end{array}$ & $\begin{array}{l}\text { Public and } \\
\text { Developer }\end{array}$ & $\begin{array}{l}\text { Public risk from } \\
\text { inadequate control; } \\
\text { private cost } \\
\text { increases }\end{array}$ \\
\hline $\begin{array}{l}\text { Domestic } \\
\text { Supply and } \\
\text { Demand }\end{array}$ & Moderate & $\begin{array}{l}\text { Shifts in both } \\
\text { characteristics can } \\
\text { change market dynamics }\end{array}$ & $\begin{array}{l}\text { Changes in market forces and } \\
\text { competition }\end{array}$ & Developer & $\begin{array}{l}\text { Price changes; } \\
\text { changed competitive } \\
\text { position }\end{array}$ \\
\hline $\begin{array}{l}\text { Fiscal } \\
\text { Resources }\end{array}$ & Moderate & $\begin{array}{l}\text { Flawed estimation of } \\
\text { volumes and impact of } \\
\text { taxes and royalties on } \\
\text { competitive position }\end{array}$ & $\begin{array}{l}\text { Company operating } \\
\text { characteristics; market changes }\end{array}$ & $\begin{array}{l}\text { Public and } \\
\text { Developer }\end{array}$ & $\begin{array}{l}\text { Lost public } \\
\text { revenues; project } \\
\text { failure }\end{array}$ \\
\hline $\begin{array}{l}\text { Construction } \\
\text { and Labour }\end{array}$ & $\begin{array}{l}\text { Moderate } \\
\text { to High }\end{array}$ & $\begin{array}{l}\text { Construction cost } \\
\text { increases; labour } \\
\text { availability }\end{array}$ & $\begin{array}{l}\text { State of economy; demand in } \\
\text { marketplace }\end{array}$ & Developer & $\begin{array}{l}\text { Project timeline } \\
\text { extended; project } \\
\text { cost increases }\end{array}$ \\
\hline
\end{tabular}

Upsets from unforeseen forces, such as radical shifts in technology and access in the Northwest Passage may change risk calculations fundamentally. Here, access to offshore resources, such as those in the Northwest Passage, and emerging paradigm shifts and improvements in technology (i.e., floating liquefaction and storage vessels) could ultimately displace the need for domestic pipelines and port facilities. While the same safety concerns would still prevail, the lower cost of acquiring and shipping products could be significantly lower than those in place today, and fundamentally shift the market, potentially making existing investments redundant and effectively stranding large capital investments. 


\section{POLICY IMPLICATIONS OF AN LNG INDUSTRY EXPANSION}

Canadian energy resources are impressively large, from both conventional and unconventional sources. However, the landlocked nature of the current resource base means that expansion and capture of value-added opportunities in the future will depend on gaining access to tidewater ports on the west and east coasts. If the objective is to build a future LNG export market, then failure to gain port access will critically delay effective competition, especially in the AsiaPacific region. An emerging alternative is to use U.S. ports, such as Jordan Cove, and transfer Canadian natural gas overland for export. This improves the prospects from more traditional reliance on exports to U.S. domestic markets, with corresponding competition with U.S. shale gas development in the near term.

Most of the impediments to developing a new LNG industry are related to the difficulty in gaining sufficient access across provinces and into tidewater port areas necessary to access new markets. That is to say, most current difficulties are domestic in nature and reflect disagreement over standards, process and compensation for affected parties and governments who would be involved in approval, operation and monitoring of the systems involved over a very long term. There is, for instance, little co-ordination on taxing and royalty charges between provinces, and an apparent disconnect between the federal government, the province of British Columbia and some First Nations regarding port facility siting and marine-safety standards. Currently, there is no collaborative standard for dealing with the issue of access and rights to non-treaty lands, or redistribution of economic benefits to landowners.

We believe that policy-makers and regulators provide the most obvious forum for addressing these issues, and that resolution of jurisdiction and agreements for siting and environmental standards will allow financing and private investment to follow - not the opposite.

LNG and natural gas market expansion is currently viable and has the potential to demonstrably contribute economic benefits to Canada, both nationally and regionally. Given the air quality and emissions performance from gas-fired electricity generation and as a transportation fuel, natural gas represents a physical and policy bridge to a more sustainable environmental pattern of living in the future; an important consideration when the large-scale forecast growth in the Asia-Pacific marketplace is taken into account.

The Asia-Pacific marketplace will be attractive to a wide range of upstream suppliers from many regions including Canada over the next 20 years. Since success there is so closely tied to contractual arrangements between supplier and buyer, early commitments to development and predictable supplies are paramount. This core precept is tied to predictable and consistent policy development; literally, risk reduction through stable public policies and support.

The policy arena, then, is the key to developing this market - or not, if the majority of Canadians are against it. The policies necessary are likely to transcend the historical strongholds of Crown-controlled resources largely controlled and overseen by individual provinces. In short, without a co-ordinated and comprehensive siting, review and permit process at the provincial and federal level, there will always be a residual uncertainty regarding establishment and operation of future LNG facilities. That uncertainty will translate to increased costs of insurance and financing in a market where margins are likely to become smaller and smaller over time. 
Time is critical in developing this market, and that suggests that the earlier that certainty with regard to the permit process is achieved, the more successful the final process will be. Success in this case will be measured in terms of fundamental agreement over the role and compensation for First Nations, environmental assurance, and rights of way. We believe that these areas should be addressed comprehensively before piecemeal consideration of projects begins, even if that may involve a short-term moratorium to develop a comprehensive energy plan for coastal access for energy projects.

This paper cannot comprehensively deal with the impacts or cost-benefit relationships implied by accessing and serving these markets. However, we can suggest that the included (nonexhaustive) list of policy concerns that should be addressed be based on a systematic and comprehensive approach that includes political issues, safety and public licence, environmental standards, and conflicting land use.

\subsection{Political Issues}

It cannot be emphasized enough that regional, provincial and federal political boundaries must be respected; however, the potential to stymie overall public benefit by applying more narrow regional standards of performance, tax and royalty standards and safety indemnification can effectively defeat long-term energy system development. Developing a co-operative agreement, for instance establishing a set of standard agreements or processes, which would serve as a template for negotiations, would be an appropriate place to start, involving not only the provinces and territories but the federal government as well.

There are precedents, albeit imperfect, where provincial governments have found it productive to work together informally (e.g., the British Columbia and Alberta Deputy Ministers working group), ${ }^{217}$ but without collaboration that brings federal representatives and authority to any agreements, they will be ad hoc and potentially unenforceable at best. The uncertainty implied by this process is not conducive to long-term finance and investment.

An important consideration in the political arena is the relationship between federal and provincial governments and First Nations, many of whom have historical and/or treaty rights that need to be considered. Fulfilling the duty to consult will require co-operation among governments and with project proponents to ensure concerns are adequately addressed.

In the long-term view of developing future energy markets, there will be a convincing need to establish energy corridors or rights of way for pipelines and wire systems. Adjudicating these in a collective sense will be more effective if policy-makers anticipate project needs (ranging from rights of way, environmental buffer zones, supporting community development, etc.) rather than reacting to them on a project-by-project basis. This effectively puts the burden of planning on the back of developers, and the burden of critical analysis primarily on stakeholders, a process that invites disagreement, misunderstanding and court challenges, ultimately disrupting a comprehensive and cohesive public policy environment as well as decision making.

\footnotetext{
${ }^{217}$ Alberta Department of Energy website, “Alberta and British Columbia Working Together," http://www.energy.alberta.ca/Initiatives/3707.asp.
} 


\subsection{Safety and Public Licence}

The public is well represented in the regulatory arena, although standards and protocols may differ by jurisdiction. Integrating and harmonizing these can provide added assurance to the finance market, ultimately offering a standardized process for construction and inspection and enforcement of standards in the future. Viewing projects on a collective basis can also bring economies of scale into the market, for instance in the area of marine safety. A collective response funded broadly can result in a safer and more productive industry (this pertains as well to the pipeline industry and rail, as well as marine environment). For instance, modern telemetry deployed in the coastal zone can substitute in part for higher coast guard presence, and result in more effective monitoring of movement and guidance for vessel passage in dangerous areas.

\subsection{Environmental Standards}

Ensuring environmental quality is a high priority for Canada, local populations and developers. Mistakes in this category can be profound and persistent, often not revealing their impacts until far into the future. The corresponding private and social costs can consequently be very high, warranting a high level of concern, intervention and regulation, but do not necessarily mean the cessation of development if the latter are undertaken in a responsible manner.

Ultimately, changes in environmental policy, whether in terms of standards or enforcement, can introduce high levels of uncertainty in the finance and development community. Policy-makers can alter the current perception of uncertain, inconsistent and potentially ineffective environmental policy by developing a comprehensive, unambiguous set of standards for the review of energy projects and by taking discussion of these standards out of the regulatory process, other than for the review of project applications. This policy change alone would result in more consistent project definition and review over time.

\subsection{Conflicting Land-Use Issues}

LNG is not the only energy product that holds promise for export from Canada. The list includes electricity, light- and heavy-oil products, refined chemical and gaseous products and radioactive fuels. Many of these will compete for access to tidewater ports, often in geographic conditions that limit or constrain the actual land area available for product delivery as well as site development and location of support communities. Developing a process for allocating all of these elements, including access corridors, will be critical and should be undertaken in a comprehensive and anticipatory manner.

There are alternatives to traditional planning by government agencies that could range from auctions or lotteries to comply with land-use permits to the evaluation of those projects with the highest expected economic returns or the highest levels of environmental protection that can give guidance while still ensuring compliance with public goals of development or land conservation. The creation of a master strategy for development and adjudication that does not rely on the courts as the ultimate arbiters is important. Creating this vision and the standards by which it can be accessed will allow a more predictable system to be organized that involves a disparate group of stakeholders to adjudicate their concerns on a collective rather than projectby-project basis. With a key goal of creating predictable land-use and environmental standards, it will be more reasonable to determine if pursuing future offshore energy markets is rational, timely and cost effective. 
In sum, this is a critical market for the future of Canada's energy sector over the next two decades. Success will only be achieved with co-operation, understanding and transparency of rules and expectations between a myriad of stakeholders and the vital investment community needed to support it.

\subsection{Fiscal Policy}

Provincial governments (with some exceptions) own mineral rights in Canada, and typically auction these rights to firms as leases, and then levy taxes on production (royalties) to recoup the value of the resource that the firms produce on behalf of the government. These royalties are above and beyond corporate income taxes, and are designed to ensure the owner of the resource - the government acting on behalf of the citizens - receives its "fair share" from the development of the resource.

The B.C. government proposed a special LNG tax in its 2014 budget. It is a two-tier tax, with a 1.5 per cent tax applied to net proceeds (revenues less expenses) after production takes place, and a second tier of up to seven per cent applied to net proceeds, with pre-production investment expenditures fully written off until recovered. ${ }^{218}$ The first tier is credited against the second-tier profit-based tax. A study from Ernst and Young for the B.C. government compares expected government revenues across current and potential LNG-exporting countries, and finds that the proposed B.C. fiscal framework, including the B.C. LNG income tax, is competitive relative to existing fiscal frameworks in Australia and the United States. ${ }^{219}$

The proposed B.C. LNG income tax is in addition to corporate income taxes paid, and the royalties paid by the producers of natural gas. This tax is, essentially, a special income tax levied on a specific type of manufacturing - liquefied natural gas production. It would be similar to applying special taxes to refining or automobile manufacturing. The effect of this tax is to raise the effective tax rate on capital, but only for LNG projects, putting them at a disadvantage relative to other forms of capital in B.C. ${ }^{220}$ Moreover, it disadvantages project proponents in B.C. relative to projects in other jurisdictions. And, as shown above, additional costs could make projects' rates of return too low to make it a feasible investment.

The B.C. government claims it is introducing the tax to ensure British Columbians receive an "appropriate return" for the natural gas produced in B.C. ${ }^{22 l}$ However, given that the province already collects royalties on production, there is no need for an LNG income tax to ensure a "fair share" to the province - unless royalties are "too low," which is an entirely different

${ }^{218}$ Government of British Columbia website, "Backgrounder: LNG Income Tax Balances Competitiveness, Fair Return," February 18, 2014, http://bcbudget.gov.bc.ca/2014/backgrounders/2014_backgrounder_3_LNG_income_tax_competitiveness.pdf.

${ }^{219}$ Ernst and Young, Analysis of the competitiveness of B.C.'s proposed fiscal framework for LNG Projects (February 18, 2014), http://www.empr.gov.bc.ca/OG/Documents/Summary\%20Competitiveness\%20Analysis\%20Report\%20$\% 2018 \% 20$ February\%202014.pdf.

${ }^{220}$ Jack M. Mintz, “B.C.'s LNG tax could bomb,” National Post, March 18, 2014, http://opinion.financialpost.com/2014/03/18/jack-m-mintz-b-c-s-lng-tax-could-bomb/.

${ }^{221}$ Government of British Columbia website, "Backgrounder: Proposed B.C. LNG Income Tax," February 18, 2014, http://bcbudget.gov.bc.ca/2014/backgrounders/2014_backgrounder_2_proposed_LNG_income_tax.pdf. 
issue. The LNG income tax is a poor policy and appears to be solely a revenue grab. ${ }^{222}$ It may be enough to prevent the development of the LNG industry in British Columbia, and continued uncertainty about its form can only delay investment decisions, putting Canada further behind in the race to supply Asia.

\section{CONCLUSIONS}

There are challenges in accessing any energy market, ranging from domestic supply and collection infrastructure, export facilities and shipping, to market demand. All of these elements are dynamic in nature, and ultimately none of them can be strictly controlled, but they can be well managed. In developing a new market, a strong additional component must be the co-operation between political and regulatory agencies, and in modern times, the role and limits of so-called social licence. ${ }^{223}$

In this research, we have found that if Canadian natural gas is sold on the open market, its cost and performance characteristics are economically competitive with projects elsewhere in the world (based on a value-chain cost comparison). Taken further, if LNG facilities are built on the Western Canadian coastline, with the cost structure for ports and liquefaction characteristics employed by the current market, then natural gas exported by this method will be competitive with other existing and foreseen projects over the next 20 years.

LNG markets operate largely on long-term contract relationships that are a function of high confidence in supply volumes, gas thermal characteristics, and stable government or regulatory relationships. In this case, Canada's abundant gas resources, extensive gas infrastructure, deep gas-industry experience, free-trade ethos and political stability are attractive to foreign investors. If tidewater ports are developed, Canada is ideally located to become a significant long-term LNG supplier to the Asia-Pacific region.

We believe the reported commitments that have already been made by major LNG project developers and buyers highlight the fundamental attractiveness of Canadian LNG export projects, and should give confidence to the policy and regulatory agencies that long-term development of this market is viable and economically attractive.

The Asia-Pacific market is dynamic and likely to be the fastest and most consistent source of growth in demand worldwide. The higher rates of growth in Asia reflect rapid economic growth, driven primarily by a need for electrical energy, and less so for heating loads, but also reflect the use of natural gas in chemical and fertilizer production. Currently, the majority of new natural gas demand has been driven by Japan and China, following the curtailment and shutdown of its nuclear power plants, and their replacement with gas turbines.

\footnotetext{
${ }^{222}$ Mintz, "B.C.'s LNG."

${ }^{223}$ We do not deal at length with the concept of a social licence in this paper, largely because it is a concept, not a rule or defined process in the regulatory lexicon. Nevertheless, it is a real concept and describes a tacit agreement by or support from the public at large, with their representatives, that the process to grant approvals or permission adequately represents the public good.
} 
While we have assumed competitive costs of production for this report (based on published industry figures), timely access to this market is critical to the overall success of Canadian firms. Long-term contracts for delivery, as well as confidence in supply capacity, are critical to initiate entry into the market. Time is of the essence in this case. For instance, if the development time for new projects lags the projected entry of new liquefaction facilities in the U.S., then given the nature of contracts, critical market share will have been ceded to other competitors. At some point this loss cannot be recovered outside extraordinary new demand growth, and the Canadian facilities, with relatively high delivered-product costs, risk getting shut out of the market.

There are obstacles that can slow or derail the success of a future Canadian LNG and natural gas industry. We have grouped these into three main categories: finance and fiscal relationships, political and regulatory uncertainty, and environmental and social-justice cooperation.

\subsection{Finance and Economic Relationships}

Currently there are more proposed LNG export projects around the world than are required to meet projected demand for the foreseeable future. While the growth period is likely to extend as much as 20 years into the future, it becomes more uncertain as time goes by, and given the contract nature of the buyer/seller relationships that are fundamental to this market, delays will allow those contracts to be signed with other nations and/or companies, effectively reducing the volume that can be shipped unless alternative buyers can be arranged.

However, there are already significant projects in the Middle East, Australia and the U.S. Gulf Coast that are capable of capturing a significant fraction of current and near-term demand increases. Some of these, such as Sabine Pass, are coming online to diversify and serve the expanding Japanese market. Others, such as the Cameron LNG project in Louisiana, are creating excess capacity to serve a market as far as 10 years in the future.

We expect that Asian demand for natural gas will grow steadily but will be differentiated by country due to the timing of distribution-network growth coupled with a lack of interconnection between countries, and the affordability of gas derived from LNG in developing economies. Although the supply of Canadian gas is abundant, access to tidewater ports is not. If access to ports is approved in the future, Canadian supplies can serve a significant but not unlimited portion of the market demand. Since approvals for new export capacity are likely to be completed in phases rather than all at once, we believe the staging will allow a consistent penetration of the market at consistent rates (relative price levels), without gaps or excess (surplus) supplies accumulating. 224

${ }^{224}$ This is an anomalous case, where not all suppliers will behave strictly rationally, and where current economic rules on construction link long-term contracts with finance for liquefaction and electricity capacity at loading ports. If the decision to build an export terminal is based primarily on contracts signed for its capacity, then there should be little or no excess supply even in the unlikely event that all proposed terminals are built at once. Further, the substantial Japanese market demand today is subject to changes in nuclear policy that could re-establish baseload capacity and diminish the appetite for imported gas supplies. As well, the current price differential supported in a large measure by purchases from Japan will face downward pressure over time, increasing shipper price risk. While this is not likely to happen in a five-year period, it is not unreasonable for it to occur in a 10-year period, especially in the face of continued high import prices. 
Canadian exports of natural gas in the form of LNG will primarily be sold under long-term sales contracts to buyers who are also equity participants in the LNG export projects. We believe that this will be the hallmark of the co-ordinated development of both port facilities and the incremental improvements of the supply chain in both British Columbia and Alberta. We expect the likely market supply from Canadian sources to be approximately two trains of an average of 4.5 MMTPA each, every five years, based on construction and access limitations.

Oil price levels will be the primary determinant of Asian LNG prices, as prices for most of the LNG sold in Asia is oil indexed. ${ }^{225}$ U.S. natural gas prices will start to have a marginal effect on LNG prices as exports from U.S. and other countries, indexed to Henry Hub, begin growing from 2015. Currently prices are attractive and represent a differential of about US\$4.73/GJ (\$5/MMBTU) if delivered to Japan. ${ }^{226}$ Spot prices have recently been higher due to winter and higher Japanese demand, and are at $\$ 17.87 / \mathrm{GJ}$ (\$18.85/MMBTU). That represents a differential of up to $\$ 7.39 / \mathrm{GJ}$ ( $\$ 7.80 / \mathrm{MBTU})$ to the spot market in 2013 .

This price differential could collapse over time if wellhead gas prices increase and margins shrink for gas supplies. Near-term markets will be driven predominantly by Japanese demand; if the nuclear facilities come back online, there will be a short-term oversupply of gas. It may be at least five years before a Canadian LNG plant is operational, by which time the nuclear situation in Japan should be clear.

\subsection{Political and Regulatory Uncertainty}

The ability of the natural gas system to expand and serve an international market will depend entirely on the characteristics of land-use and permit approvals, both from the federal and provincial governments as well as the landowner and public at large. For instance, one of the ports may be developed with oil-supply pipes in the same right of way. This will complicate the approval and port-management issues.

Lacking a co-ordinated and timely approval of projects (including pipeline rights of way, agreements with First Nations and demonstrated safety and handling plans) will erode the confidence and interest of the financial community. This will add costs to project finance agreements. This "risk" characteristic is also known to the buyer community, which will see additional offers as surplus supplies from unconventional gas projects begin to appear on the market.

Uncertainty is difficult to price or evaluate in advance. However, the nature of regulatory delays or project-mitigation costs can be serious enough to delay or impose excessive costs on projects, potentially defeating them. Just as serious, though, are projects that are not burdened with these reviews and requirements, later deemed by the financing community as likely to fail and cause future unfunded liabilities.

\footnotetext{
${ }^{225}$ The Haisla Nation/Golar B.C. LNG Project in Kitimat has reportedly signed contracts based on Henry Hub indexation. "In fact, the sales contract, which will see some gas go to one of the world's largest LNG ship owners, values gas according to depressed U.S. and Canadian prices, rather than the far more lucrative international prices that are tied to oil," Nathan Vanderklippe, "BC LNG inks Asian sales contract," The Globe and Mail, January 20, 2013, http://www.theglobeandmail.com/report-on-business/industry-news/energy-and-resources/bc-lng-inks-asiansales-contract/article7563307/.

${ }^{226}$ We calculate a representative price of Canadian LNG in current markets as US\$11.05. This is only for current comparison, since a $\$ 3.95 / \mathrm{MMBTU}$ price assumed for wellhead gas is not realistic over the long term.
} 
Finally, taxation and royalty concerns of all levels of government will be a key issue for discussion, since success of the industry will depend on co-operation between governments for siting, tax levies and support of employment needs for the projects. Ultimately, this can be a deciding factor in project success, since excess levels of tax or inappropriate tax applications can render projects unfeasible in the marketplace.

\subsection{Environmental and Social-Justice Relationships}

Environmental standards and compliance, and social approval of new coastal facilities, are critical for the industry to develop. This will mean additional attention on the part of developers and the public regulator to conditions and standards that will withstand scrutiny from observers and indemnify all parties with regard to potential upsets or damage in the future. While the LNG shipping industry has an extremely good track record, marine safety will prove to be a significant regulatory concern; added costs here may demand collective or novel approaches to guaranteeing a high standard of safety and oversight within Canadian national waters and beyond.

The overriding environmental issues surround pipeline location and right-of-way impacts, inspection and leak detection, and air quality issues associated with electric power operations necessary to maintain liquefaction and port facilities. The ruggedness of the terrain and its seismicity could add to costs and time for identifying suitable pipeline routes, securing right of ways and permits, and constructing pipelines across the Coastal range. Electricity is likely to be provided totally "onsite" with gas-fired power generation, with no grid support, for economic performance and to satisfy likely regulatory and policy concerns. This will potentially raise costs and make it difficult to meet the government's greenhouse gas emissions targets. The availability and cost of labour for remote project sites will be an issue, affecting the cost and schedule of export projects.

Right-of-way and access challenges from landowners, First Nations and environmentalists are likely to dominate decision forums as the projects are advanced, and the standards and mitigation requirements are likely to impose additional project costs that may reduce the profitability and incentive for any given project. 


\section{APPENDIX A: DETAILED COUNTRY ANALYSIS (DEMAND)}

Appendix A reviews the current and future natural gas demand and LNG demand by region and/or country, beginning with traditional LNG buyers, followed by non-traditional buyers and concluding with emerging LNG buyers.

\section{A1 North Asian Traditional LNG Buyers: Japan, South Korea and Taiwan}

\section{A1.1 CHARACTERISTICS OF TRADITIONAL NORTH ASIAN MARKETS}

LNG buyers in Japan, South Korea and Taiwan are referred to in the LNG industry as "traditional" buyers because of the characteristics they share: developed economies; regulated, risk-averse utility buyers; long histories of buying LNG on similar, traditional commercial terms; acceptance of oil-indexed pricing formulas; requirements for LNG with high heating values ("rich" gas); and the financial capacities that have provided the contractual support to launch most of the LNG projects in the Asia-Pacific region and the Middle East. Traditional LNG buyers represent low commercial risk, and buyers in Japan, South Korea and Taiwan have been the buyers of choice for LNG suppliers to the Asia-Pacific region. The symbiotic relationships between LNG suppliers and traditional LNG buyers, and the "rules of the game" between them, are well established. Led by Japan, these North Asian LNG buyers have long dominated the LNG market in the Asia-Pacific region, and indeed the world. In 2012, North Asian LNG buyers accounted for 58 per cent of global LNG trade, and 83 per cent of LNG imports in the Asia-Pacific region. ${ }^{1}$ Figure A1.1 shows LNG imports by supply country for Japan, South Korea and Taiwan; imports have almost tripled between 1993 and 2012.

FIGURE A1.1: NORTH ASIA (JAPAN, SOUTH KOREA AND TAIWAN) LNG IMPORTS BY SUPPLY COUNTRY

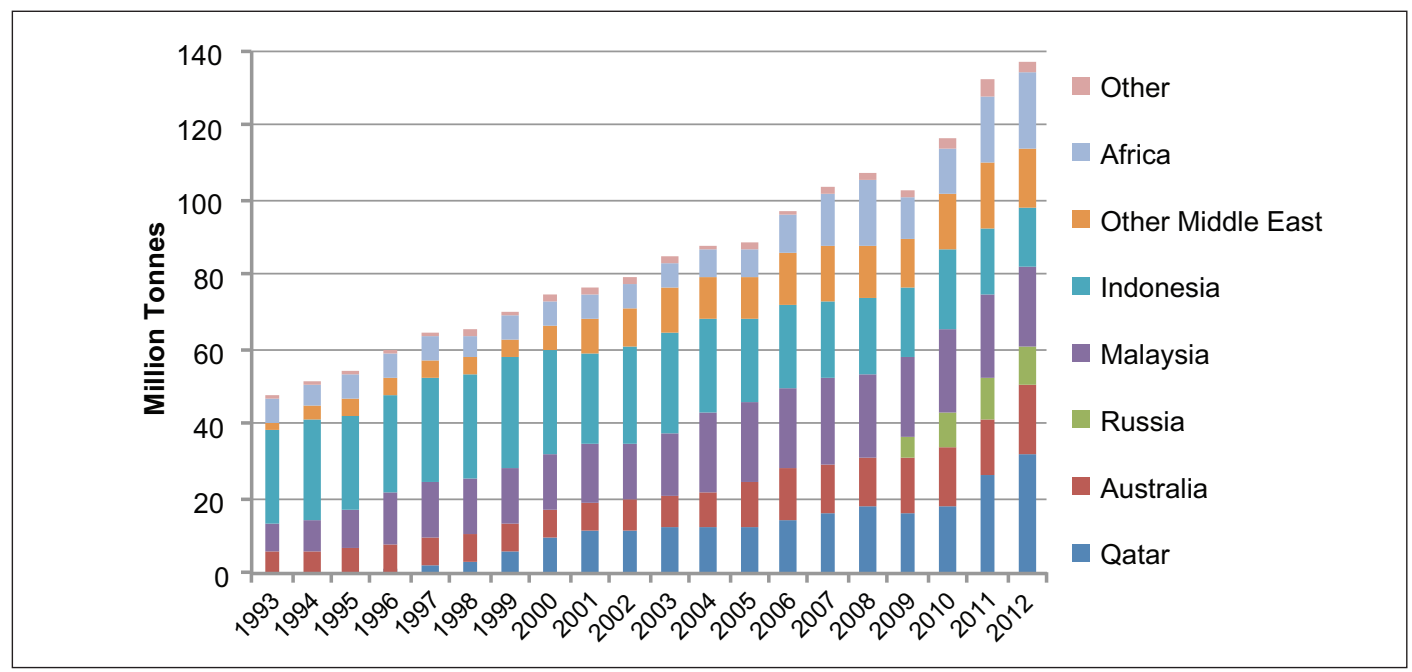

Note: Africa includes Algeria, Brunei, Egypt, Equatorial Guinea and Nigeria. "Other Middle East" includes Oman, the United Arab Emirates and Yemen. "Other" includes Belgium, France, Norway, Peru, Spain, Trinidad and Tobago, the United States, and "non-specified/other."

Source: IEA, "World - Natural Gas imports by origin," IEA Natural Gas Information Statistics (database), 2013, doi: 10.1787/data-00555-en.

1 Authors' calculations, based on: IEA, "World - Natural Gas imports by origin”, IEA Natural Gas Information Statistics (database), 2013, doi: 10.1787/data-00555-en. 
The Asia-Pacific LNG market is predominantly based on long-term sale-and-purchase agreements (SPAs), usually extending 20 years or longer. In 2012, the volume covered by existing contracts in Japan, South Korea and Taiwan was equivalent to 80 per cent of imports; for the Asia-Pacific region this figure is 85 per cent. ${ }^{2}$ In 2009, 86 per cent of LNG deliveries in the region, and 89 per cent of deliveries to Japan, South Korea and Taiwan, were under longterm contracts. ${ }^{3}$ Long-term contracts satisfy buyers' concerns about security of supply and sellers' needs for commercial revenue security. These contracts underpin project infrastructure commitments; in the current market, new construction for liquefaction and regasification will not proceed without them. Unlike in the Atlantic Basin (Europe and North America), there are not extensive supplies of gas available from pipeline sources in the Asia-Pacific region. Thus, expansion of gas supply is tied to new LNG facilities. Recent growth of the Asia-Pacific spot and short-term trade - spot volumes imported increased 167 per cent between 2008 and $2012^{4}$ - reflects the inability of buyers to commit to long-term purchases for several reasons, including uncertain government policies, negotiating impasses over price indices, and uncertain LNG demand. These in turn were compounded by a sudden 15.8 MMTPA increase in Japanese consumption between 2010 and 2012 due to that country's shift away from nuclear energy after the Fukushima disaster. ${ }^{5}$

Historically, North Asian LNG buyers have had similar requirements when buying LNG:

- Security of supply (low political risk, strong project sponsors and low technical risk);

- Diversity of supply (enhancing security of supply);

- Nominal equity participation in supply projects to gain independent opinion and judgment;

- LNG with high heating values to meet gas-utility specifications.

More recently, as national economic competitiveness has emerged as an issue and the uncertainty about LNG demand has grown, North Asian buyers have sought:

- Lower rates of price changes, if LNG price is indexed to oil prices; ${ }^{6}$

- Alternative, and hopefully lower-cost pricing formulas (e.g., Henry Hub indexation);

- Quantity flexibility (to increase/decrease quantities in the face of uncertain demand);

- Destination flexibility (for short-term changes in demand and commercial trades);

- Mixtures of short-, medium- and long-term commitments (to manage uncertain demand);

- Increased participation in upstream resources (for security of supply and price hedging).

2 Authors' calculations, based on: IEA, “World - Natural Gas imports”; and Bloomberg POTN (Poten \& Partners) LNG contract database.

3 Based on calculating the difference between total volumes and spot volumes imported to Asia (China, India, Indonesia, Japan, South Korea, Taiwan and Thailand), as reported by the International Group of Liquefied Natural Gas Importers (see: GIIGNL, The LNG Industry in 2009 (Paris: GIIGNL, 2009). According to Poten \& Partners, in 2009 more than 95 per cent of LNG deliveries in the region were under long-term contracts, though they do not provide a citation for their number (Poten \& Partners, "2015 - 2035 LNG Market Assessment Outlook for the Kitimat LNG Terminal," October 2010).

4 Authors' calculations, from: GIIGNL, The LNG Industry ... , 2008 through 2012 editions.

5 IEA, "World - Natural Gas statistics," IEA Natural Gas Information Statistics (database), 2013, doi: 10.1787/data00482-en.

6 See Section 2.1 in main body of the report for a discussion of pricing mechanisms. 
In addition to their common commercial concerns, North Asia-Pacific buyers have similar technical requirements for LNG with higher heating values ("rich" gas; see Appendix B for details). Isolated from the rest of Asia, with limited domestic production, all three developed their natural gas industries with distribution-system gas specifications based on LNG as their primary source of natural gas. Gas utility companies control the high heating value (HHV) of natural gas in their systems; LNG supplies that are lower in heating value ("lean" gas) are "spiked" with liquified petroleum gas (LPG) to raise the heating value to the pipeline specification. 7 Japan's LNG supplies historically originated from Indonesia, Malaysia, Australia, the United Arab Emirates and Oman, mostly sourced from gas containing higher LPG content, with higher heating values, so for many years, spiking was not a significant burden. An option for individual buyers, especially gas utilities, is to specify limits on the portion of their LNG supplies that could come from suppliers of "lean" (low heating value) LNG.

The situation with respect to high-heating-value gas specifications is similar in South Korea and Taiwan. The pipeline high-heating-value specification in South Korea has been based on available supply characteristics. ${ }^{8}$ An interconnected system of import facilities and pipelines allows South Korea more flexibility to accommodate low-heating-value LNG supplies through segregation of LNG from different sources, blending of LNG from different sources, and LPG spiking.

However, as new LNG supplies with lower heating values come on the market, Japanese, South Korean and Taiwanese buyers have found it increasingly more difficult to buy LNG that does not require significant LPG spiking, which makes many new supplies less attractive from an operational and economic perspective (depending on the price spread between LNG heat value and LPG heat value). Examples of LNG supplies with low heating values being marketed today include LNG from the Gorgon project in Western Australia, the coal-bed methane projects in Eastern Australia, and all liquefaction projects in North America.?

Although Japan, South Korea and Taiwan have similar characteristics as LNG buyers, South Korea stands apart in one key respect. Historically, and with only recent, minor exceptions, the state-owned Korea Gas Corp. (KOGAS) has acted as South Korea's monopsony LNG buyer, while Japan has purchased LNG through dozens of electricity and gas utility companies. ${ }^{10}$ As a consequence, South Korea has been able to commit to large, long-term LNG purchases, while each Japanese buyer has typically made small, incremental long-term purchases (South Korea's average contract volume is over 50 per cent larger than Japan's.). KOGAS's ability to make large purchase commitments has made South Korea a key target market for greenfield liquefaction projects that are getting increasingly larger and in need of large "foundation buyers" to underpin the project. A rule of thumb suggested by industry experts is that liquefaction projects are not sanctioned until at least 80 per cent of the project's capacity is committed under long-term contracts.

\footnotetext{
7 International Gas Union and BP, Guidebook to Gas Interchangeability and Gas Quality (2011).

8 South Korea has one of the highest heating value specifications in consumed gas (see Appendix B, Table B1).

9 See Appendix B, Table B2 for a comparison of LNG by heating value from various export terminals around the world.

10 Of South Korea's 33 contracts currently in force, KOGAS is the buyer for 31 . In contrast, Japan has 26 different buyers with 137 contracts currently in force. Source: Bloomberg POTN (Poten \& Partners) LNG Contract Database.
} 
Japanese buyers once acted collectively in one of two "buyers' clubs" (the Eastern Buyers or the Western Buyers). ${ }^{l l}$ Negotiating together, they secured the small quantities that each needed, while leveraging the buying power of a larger buyer. Long-term purchase commitments with LNG suppliers would typically include multiple Japanese buyers under the same commercial terms. This approach fell away as the Japanese government liberalized the utility industry to encourage competition across, and between, the electric and gas utility sectors. ${ }^{12}$ Now, each Japanese buyer acts individually and, as a consequence, Japanese buyers are not as critical to the launch of new liquefaction projects as they once were. Project sponsors have been forced to look to South Korea and China for large-scale foundation customers to underpin project economics.

Japan and South Korea have both suffered from regulatory uncertainty. Both have sought to liberalize their gas and power industries. While achieving only limited success in lowering market prices through increased competition, Japan and South Korea have created uncertainties that have resulted in all players delaying firm LNG-procurement decisions. In a recent press release, Wood Mackenzie stated that "policy and regulatory uncertainty in Japan and South Korea could result in less new Liquefied Natural Gas (LNG) supply being developed, forcing continued tightness in the Pacific LNG market beyond 2020 and perpetuating high spot prices." ${ }^{13}$

\section{A1.2 JAPAN}

Tokyo Electric Power Company (TEPCO) started importing LNG into Japan from Kenai LNG in Alaska in 1969. ${ }^{14}$ Japan played an indispensable role in launching and growing the LNG industry, serving as the sole buyer for many exporting countries. The demand for gas in Japan has underpinned a large and growing LNG market in the Asia-Pacific region. In 1993, Japan accounted for 66 per cent of global LNG imports, importing LNG from Brunei, the United Arab Emirates, Oman, Indonesia, Malaysia, and Australia, as well as Alaska. However, as other buyers entered the market and the growth of Japan's LNG imports leveled off, Japan's share of global LNG imports declined to 54 per cent by 2000 and to 33 per cent in 2010, despite the total imported volume growing 2.8 per cent per year during this period (Figure A1.2) ${ }^{15}$

11 Little detail is available on the exact nature of these consortiums, however, Jonathan Stern notes the existence of a Western Buyers consortium; see: J. Stern, "The Pricing of Gas in International Trade," in The Pricing of Internationally Traded Gas, ed. J. Stern (Oxford: Oxford University Press, 2012), Chapter 2. LNG Japan Corporation was part of a buyers' consortium. Source: LNG Japan Corporation website, "Indonesia LNG Project," http://www.lngjapan.com/english/work/.

12 Tetsuo Morikawa and Hiroshi Hashimoto, "Japan's new challenge and possible solutions in LNG procurement activities in the wake of less availability of nuclear power capacity," Working Paper (Japan: The Institute of Energy Economics, Japan, August 2012), https://eneken.ieej.or.jp/data/4436.pdf.

13 Wood Mackenzie, "Uncertainty in Japan and Korea’s LNG Markets Will Prolong Tight Asian Market Beyond 2020," September 9, 2013.

14 EIA website, "Japan," http://www.eia.gov/countries/cab.cfm?fips=ja.

15 Authors' calculations, based on IEA, "World - Natural Gas imports." 


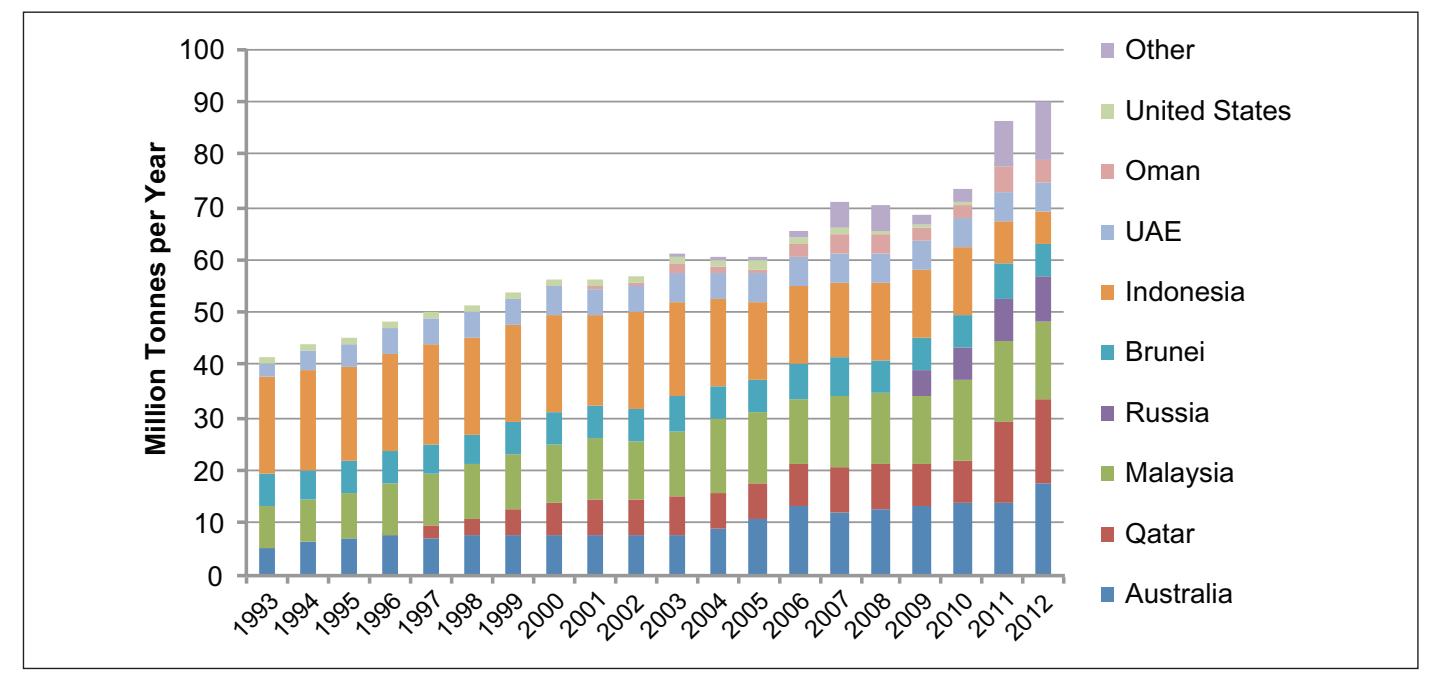

Note: "Other" includes Algeria, Belgium, Egypt, Equatorial Guinea, France, Nigeria, Norway, Spain, Trinidad and Tobago, Yemen and "non-specified/other."

Source: IEA, “World - Natural Gas imports by origin,” IEA Natural Gas Information Statistics (database), 2013, doi: 10.1787/data-00555-en.

Japan's 30 receiving terminals have a combined capacity of 192 MMTPA (261 BCM), and are owned mainly by electricity and gas utilities. ${ }^{16}$ Regasification capacity continues to grow through expansion of existing terminals and the construction of new terminals. By the end of 2015, regas projects that are currently under construction will increase the country's LNG import capacity to 265 BCM per year (194 MMTPA). ${ }^{17}$ Between 1993 and 2012, the utilization rate for Japan's import terminals averaged 34 per cent, and utilization only increased above 40 per cent in 2011 and 2012. ${ }^{18}$ Japan's import capacity is well above demand, but total import volume is constrained by infrastructure and port size. ${ }^{19}$ Each terminal serves a relatively small geographic area around the terminal; hence, each terminal has storage and send-out capacities to ensure very high service reliability. ${ }^{20}$ Some terminals have separate tanks to store LNG supplies with different heating values. ${ }^{2 l}$

Historically, natural gas has supplied about 12 per cent of Japan's energy needs, and almost all of that natural gas is imported as LNG. ${ }^{22}$ Between 1980 and 2000, approximately 74 per cent of Japan's natural gas use supplied electricity generation; this fell to 63 per cent in 2010, and increased to 68 per cent in $2011 .^{23}$ Government efforts to liberalize Japanese energy markets

${ }^{16}$ GIIGNL, The LNG Industry in 2012 (Paris: GIIGNL, 2012), http://www.giignl.org/publications/lng-industry-2012.

17 CERI, “Global LNG: Now, Never, or Later?”, Study No. 13 (Calgary, Alta.: Canadian Energy Research Institute, January 2013).

18 Authors' calculations, based on: IEA, "World - Natural Gas imports" and GIIGNL, The LNG Industry in 2012.

19 EIA website, "Japan."

20 ibid.

21 KBR, a consulting firm, notes: "one source of LNG to Japan is Kenai, Alaska where the LNG is nearly pure methane. This LNG must have LPG injection for interchangeability purposes." KBR, "Natural Gas Specification Challenges in the LNG Industry,” January 2007.

22 BP, BP Statistical Review of World Energy June 2013 (2013), http://www.bp.com/content/dam/bp/pdf/statisticalreview/statistical_review_of_world_energy_2013.pdf.

23 Authors' calculations, from: IEA, "Electricity Information 2013." 
have led to more competition between Japanese LNG buyers. ${ }^{24}$ Gas utility companies have ventured into power generation, and electric utilities have been marketing gas to gas-utility customers. In addition to putting pressure on historical collaborative relationships between LNG buyers in Japan, this increased competition has made the utilities more sensitive to price differences in LNG delivery.

This price sensitivity has been heightened by Japan's struggle to remain economically competitive with countries with lower energy costs (e.g., China). Gas prices and electricity prices in Japan are amongst the highest in the world, as shown in Figure 2.2 (main document). In 2013, Japan paid an average price of \$16.02/MMBTU (\$15.18/GJ) for LNG, compared to $\$ 14.94 /$ MMBTU $(\$ 14.16 / \mathrm{GJ})$ in South Korea.$^{25}$ Correctly or not, the political establishment believes that Japan would pay less for LNG if it could buy LNG at "world market prices" (e.g., indexed to Henry Hub instead of oil prices). The first LNG export contracts from Sabine Pass in the U.S. Gulf Coast were priced on a "Henry Hub-plus" basis; however, whether or not Henry Hub-indexed prices are lower than traditional oil-linked contracts will depend on both North American supply and demand forces and the price of oil. ${ }^{26}$ As LNG suppliers outside of the U.S. have been hesitant to consider price formulas that do not include oil-price indexation, there have been negotiating stalemates between many LNG suppliers and buyers for several years.

A shrinking population and de-industrialization in the face of foreign competition are real concerns in Japan and they have contributed to the uncertainty regarding future LNG demand, even before the Fukushima nuclear disaster in March 2011. With 50 reactors, Japan has 49 GW of nuclear power plants, representing about 17 per cent of Japan's installed generation capacity. ${ }^{27}$ Prior to the Fukushima-Daiichi event, nuclear power supplied about 27 per cent of Japan's electricity supply (see Figure A1.3). The government's 2010 electricity supply plan showed nuclear capacity growing to about 41 per cent of installed capacity by 2019 , and eventually to over half of Japan's electricity supply. ${ }^{28}$

In the aftermath of the Fukushima incident, Japan quickly ramped up electricity production from non-nuclear power plants in 2011 and 2012. Japan increased LNG imports from 73 MMT (98.7 BCM) in 2010 to 90 MMT (121.6 BCM) in 2012 as all 50 nuclear reactors in the country were shut down. ${ }^{29}$ With imports from 21 countries in 2012, Japan remains the largest LNG importer in the world, accounting for 38 per cent of global LNG imports, up from 33 per cent in $2010 .^{30}$

${ }^{24}$ For a brief overview of the liberalization of gas markets in Japan, see: Osaka Gas website, "Japanese Gas Business," http://www.osakagas.co.jp/en/ir/library/ar/pdf/2010/10_12.pdf.

25 For Japan: World Bank, "World Bank Historical Commodity Price Data," http://econ.worldbank.org/WBSITE/EXTERNAL/EXTDEC/EXTDECPROSPECTS/0, contentMDK:21574907 menu PK:7859231 pagePK:64165401 piPK:64165026 theSitePK:476883,00.html; For Korea: Korea Energy Economics Institute, "Monthly Energy Statistics," April 2014, http://www.keei.re.kr/keei/download/MES1404.pdf.

26 Jonathan Stern, "International gas pricing in Europe and Asia: A crisis of fundamentals," Energy Policy 64, 1 (2014): 43-48. For more discussion of pricing, see Section 2.1.

27 World Nuclear Association, "Nuclear Power in Japan”, world-nuclear.org, updated October 16, 2013; and EIA website, "Japan."

28 World Nuclear Association, "Nuclear Power."

29 IEA, "World - Natural Gas imports."

30 ibid. 
FIGURE A1.3: JAPAN'S ELECTRICITY SUPPLY BY FUEL SOURCE, BEFORE AND AFTER FUKUSHIMA

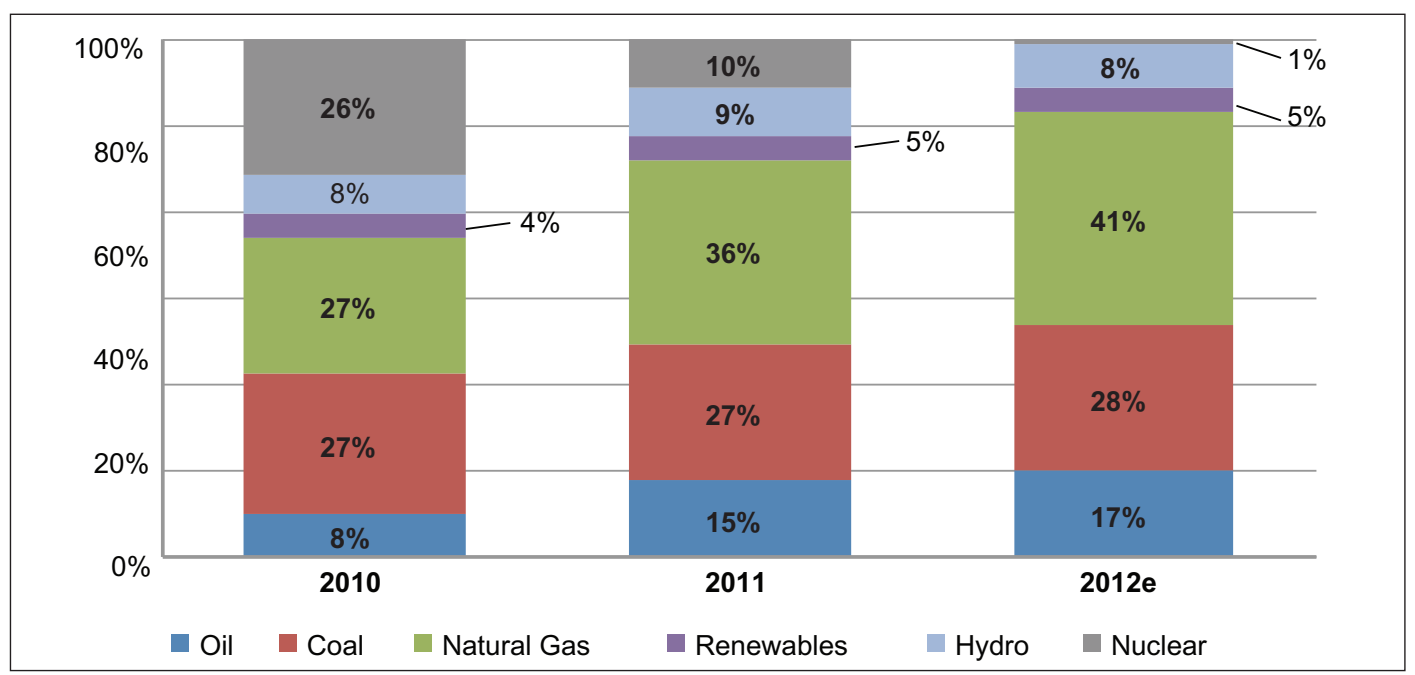

Source: IEA Statistics, “Electricity Information 2013," ISBN 978-92-64-20308-2. Percentages based on gross electricity production.

The outlook for LNG demand in Japan has become even more uncertain, given a lack of clarity regarding the future of nuclear power in the country. Japan's 2010 energy plan planned for nuclear's share of energy generation to increase to 50 per cent by 2030; the Fukushima disaster prompted differing opinions on the future role of nuclear, with the current prime minister being pro-nuclear, and the previous prime minister being anti-nuclear. ${ }^{3 l}$ Not surprisingly, views in Japan range from those who want to permanently decommission all nuclear plants to those who call for the return of all but a handful of "unsafe" plants to operation and the building of new nuclear plants. The current political establishment is generally supportive of returning "safe" plants to service. However, in seismically active post-Fukushima Japan there is much apprehension regarding the safety of all nuclear power plants. Many will not be deemed safe enough to return to operation.

A new energy plan has not yet been released, though the draft plan indicates that nuclear will continue to play an important role. ${ }^{32}$ The process of regulatory clearance for restarting Japan's 50 reactors is slow and will take some years. The Institute of Energy Economics, Japan, has recently stated that Japan may have only four nuclear reactors back online by March $2015 .^{33}$ But, even if some nuclear power plants come back online, others will be permanently retired as they reach the end of their 40-year lives. There are no firm plans in place now to construct new nuclear plants. ${ }^{34}$

31 EIA website, "Japan."

32 Norihisa Hoshino et al., "Energy policy revised but intent remains same: Restart nuke reactors," The Asahi Shimbun, February 20, 2014, http://ajw.asahi.com/article/0311disaster/fukushima/AJ201402200063.

33 Osamu Tsukimori and Rebekah Kebede, "Japan on gas, coal power building spree to fill nuclear void," Reuters, October 15, 2013, http://www.reuters.com/article/2013/10/16/us-japan-power-outlook-idUSBRE99F02A20131016.

34 World Nuclear Association, "Nuclear Power." 
A paper written by the planning and LNG-trading departments of Osaka Gas Co. Ltd., and published by The Oxford Institute for Energy Studies, methodically address the impact of Fukushima on Japan's energy complex and describe how, through increased utilization of fossil fuel plants and demand-conservation measures - both enforced and voluntary - Japan has coped with the reduction in nuclear electricity generation. ${ }^{35}$ The authors forecast Japan's future LNG requirements based on a range of scenarios regarding the future use of nuclear power facilities. They show a range of LNG demand for 2015 from 75.5 to 84.8 MMT and for 2020, 78.1 to 88.7 MMT, depending on decisions regarding nuclear power.

Despite the Japanese government's strong commitment to the Kyoto Protocol, the country has been forced to rely more on fossil fuels, including oil and spot and short-term purchases of LNG, to generate electricity in the last two years. Japan is expected to start up 12 new gasfired power plants and two coal-fired plants by the end of 2014 with the goals of reducing consumption of oil in power generation and providing additional reserve margin. ${ }^{36}$ As growth in non-power demand for natural gas is expected to be small, the main uncertainty regarding the forecast of Japan's LNG demand is the power sector. ${ }^{37}$

The cumulative effect of Japan's LNG demand uncertainties - domestic competition; the tantalizing possibility of buying lower cost, Henry Hub-indexed LNG from North America; feared de-industrialization; and nuclear power policies - have made it very difficult for Japanese LNG buyers to make long-term LNG purchase commitments. Hence, Japan has been relying on high-cost spot and short-term LNG purchases to help it traverse this period of uncertainty; in 2012, Japan's imports were 90 MMT while LNG contracts in force only covered 68.5 MMT. ${ }^{38}$ An unintended consequence of Japan's inability to commit to new longterm LNG supplies has been a delay in the launch of liquefaction projects that could provide the long-term, secure LNG supplies that Japanese LNG buyers seek.

In the meantime, Japan remains uncomfortably dependent on LNG supplies from the Middle East. In 2012, Qatar alone met almost 18 per cent of Japan's LNG demand, while the rest of the Middle East and Africa supplied almost 28 per cent. ${ }^{39}$ Japan's biggest source of short-term LNG purchases in 2011 and 2012 was Qatar, which supplied an additional 5.7 MMT in 2011 and 5.2 MMT in 2012. ${ }^{40}$ Figure A1.4 demonstrates the changes in Japan's LNG supply mix post-Fukushima; supplies from Indonesia declined, while Qatar, Australia and the Middle East and North Africa increased their sales to Japan.

\footnotetext{
35 Akira Miyamoto et al., "A Realistic Perspective on Japan's LNG Demand after Fukushima,” Working Paper N62 (The Oxford Institute for Energy Studies, June 2012)

36 Osamu Tsukimori and Rebekah Kebede, "Japan on gas."

37 Sixty-eight per cent of Japan's 2011 primary demand for natural gas is accounted for by the power sector; the share for natural gas in total final consumption in 2011 was only 11 per cent. Source: IEA, World Energy Outlook 2013 (Paris: OECD/IEA, 2013).

38 IEA, "World - Natural Gas statistics"; and Bloomberg POTN (Poten \& Partners) LNG Contract Database.

39 EIA, "World - Natural Gas imports."

40 GIIGNL, The LNG Industry in 2011 (Paris: GIIGNL, 2011), http://www.giignl.org/publications/lng-industry-2011; The LNG Industry in 2012.
} 
Situated halfway between North America and North Asia, and with flexible supply contracts and shipping capacity, Qatar has the unique ability to redirect LNG cargoes from one continent to the other in pursuit of the highest LNG prices in North America, Europe and Asia. Qatar has been a reliable LNG supplier to Japan, but it sits inside the Strait of Hormuz and supply from Qatar could be easily interrupted in the event of hostilities in the Middle East. Japan's supply of LNG and oil from the Middle East could be severely curtailed at the same time, a significant risk to security-conscious Japan. This sentiment can be traced directly to Japan's dependence (with limited domestic production) on a range of critical energy products from nuclear fuels to oil and natural gas.

FIGURE A1.4: JAPAN'S LNG IMPORTS BY SUPPLY COUNTRY (2010 - 2012)

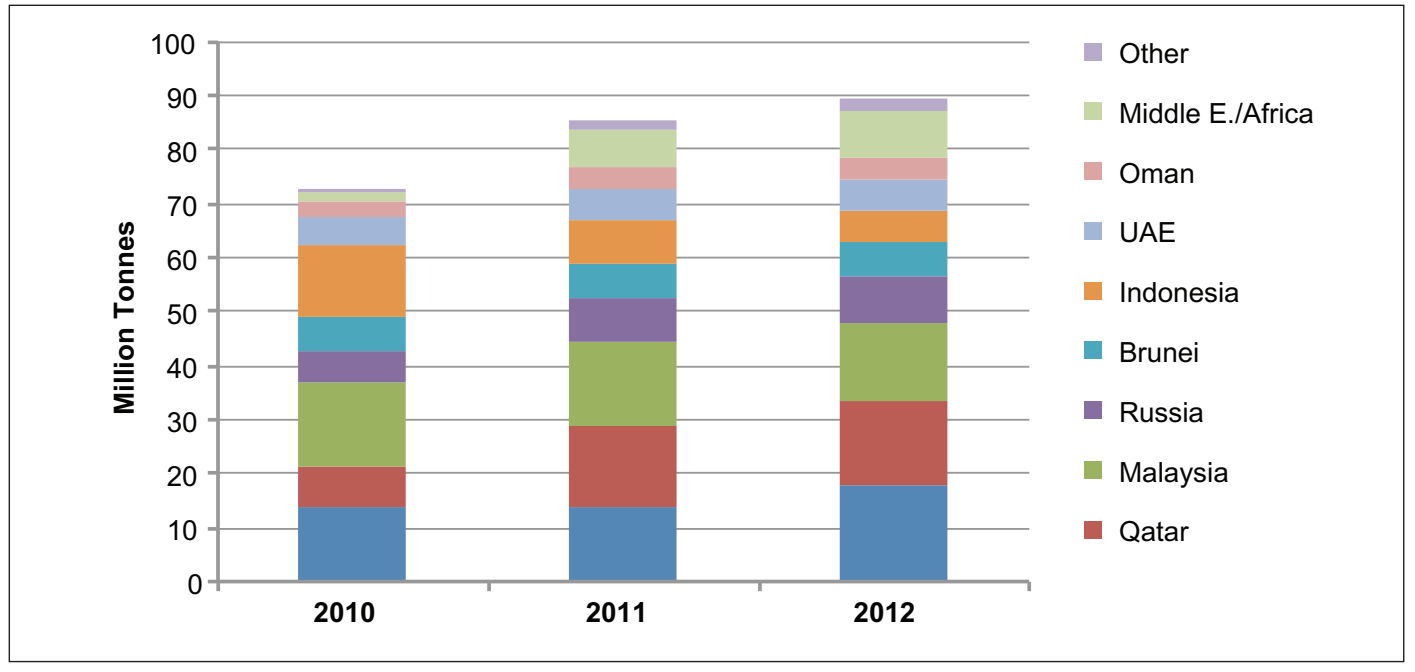

Note: Middle East/Africa includes Algeria, Egypt, Equatorial Guinea, Nigeria and Yemen. "Other" includes Belgium, France, Norway, Peru, Spain, Trinidad and Tobago, the United States and "non-specified/other."

Source: IEA, "World - Natural Gas imports by origin," IEA Natural Gas Information Statistics (database), 2013, doi: 10.1787/data-00555-en.

Despite the great uncertainty regarding Japan's future LNG requirements, analysts have attempted to project Japan's future supply-demand balance. PFC Energy concluded that Japan faces a minor supply-demand gap through 2020, assuming that preliminary contracts with sanctioned supply projects are transformed to binding contracts, which has historically been the case with Japanese buyers. ${ }^{41}$ It should be noted that PFC has assumed that Japan's LNG demand will drop between 2012 and 2015, as some nuclear plants are returned to operation, before increasing again starting in 2015 .

Figure A1.5 shows Japan's forecast demand for natural gas and sources of supply between 2015 and 2035. Based on a conservative growth-rate estimate of 0.1 per cent annually, there is little room for new sources of supply until 2025 , unless the preliminary contracted sources (Freeport LNG and Cameron LNG from the United States) fail to deliver.

41 PFC Energy, Global LNG Supply and Demand Study, May 2013. 
FIGURE A1.5: JAPAN'S NATURAL GAS SUPPLY-DEMAND BALANCE

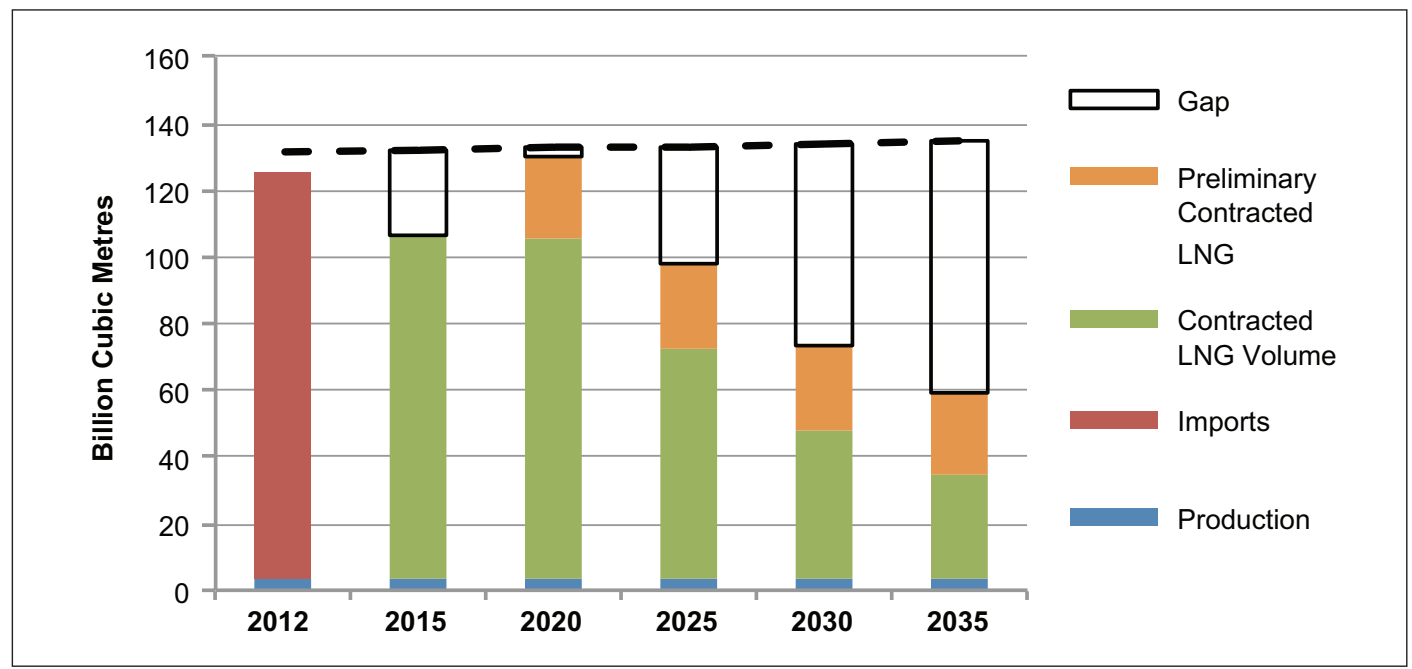

Notes: Production is assumed to stay constant at 2012 volume. Demand is forecast to increase at 0.1 per cent per year (from: IEA, World Energy Outlook 2013, central scenario, the New Policies Scenario). Production, imports and consumption (demand) data for 2012 from: IEA, "World - Natural Gas statistics," IEA Natural Gas Information Statistics (database), 2013, doi: 10.1787/data-00482-en. Contract volumes from: Bloomberg POTN (Poten \& Partners) LNG contract database. Contracts defined as preliminary are with projects where no final investment decision has been made for the supplier.

\section{A1.3 SOUTH KOREA}

The LNG industry in South Korea started with the formation of the state-owned Korea Gas Corp. (KOGAS) in 1983. KOGAS started importing LNG and supplying gas to South Korean power plants in 1986, and commenced city gas supplies to Seoul the following year. ${ }^{42}$ In 1990 , the government announced a master plan for a nationwide natural gas distribution system. ${ }^{43}$ KOGAS's system has expanded to three LNG import terminals and a 3,562-kilometre nationwide pipeline network, the most expansive system of integrated gas infrastructure in the Asia-Pacific. ${ }^{44}$ A fourth KOGAS import terminal is under construction, with an expected inservice date of 2014 or 2015, increasing KOGAS's import capacity from 89.7 MMTPA to about 96.6 MMTPA. ${ }^{45}$ As South Korea's sole LNG wholesale gas distributor, KOGAS purchases LNG and supplies natural gas to power plants, gas-utility companies, and city gas companies. ${ }^{46}$

With very limited indigenous hydrocarbon resources, South Korea quickly became the secondlargest LNG importer in the world. South Korea's share of global LNG imports were 6.8 per cent in 1993, growing to 13.6 per cent in 2000 and 14.9 per cent in $2012 .{ }^{47}$ South Korea's natural gas consumption has grown on average 14 per cent per year since 1987, and 45 per cent

\footnotetext{
42 KOGAS website, “Our History - 1980's," http://www.kogas.or.kr/en/who/history/history_4.action.

43 KOGAS website, “Our History - 1990's," http://www.kogas.or.kr/en/who/history/history_3.action.

44 KOGAS website, “Our Profile," http://www.kogas.or.kr/en/who/profile/profile.action.

45 GIIGNL, The LNG Industry in 2012.

${ }^{46}$ KOGAS website, "Business System," http://www.kogas.or.kr/en/what/business/system.action.

47 IEA, "World - Natural Gas imports."
} 
in the last three years, from 34 BCM (25.3 MMT) in 2009 to 50 BCM (36.8 MMT) in 2012 (Figure A1.6). ${ }^{48}$ Domestic production of natural gas started in 2005, but has averaged only one per cent of annual domestic consumption. ${ }^{49}$

FIGURE A1.6: SOUTH KOREA'S LNG IMPORTS BY SOURCE COUNTRY

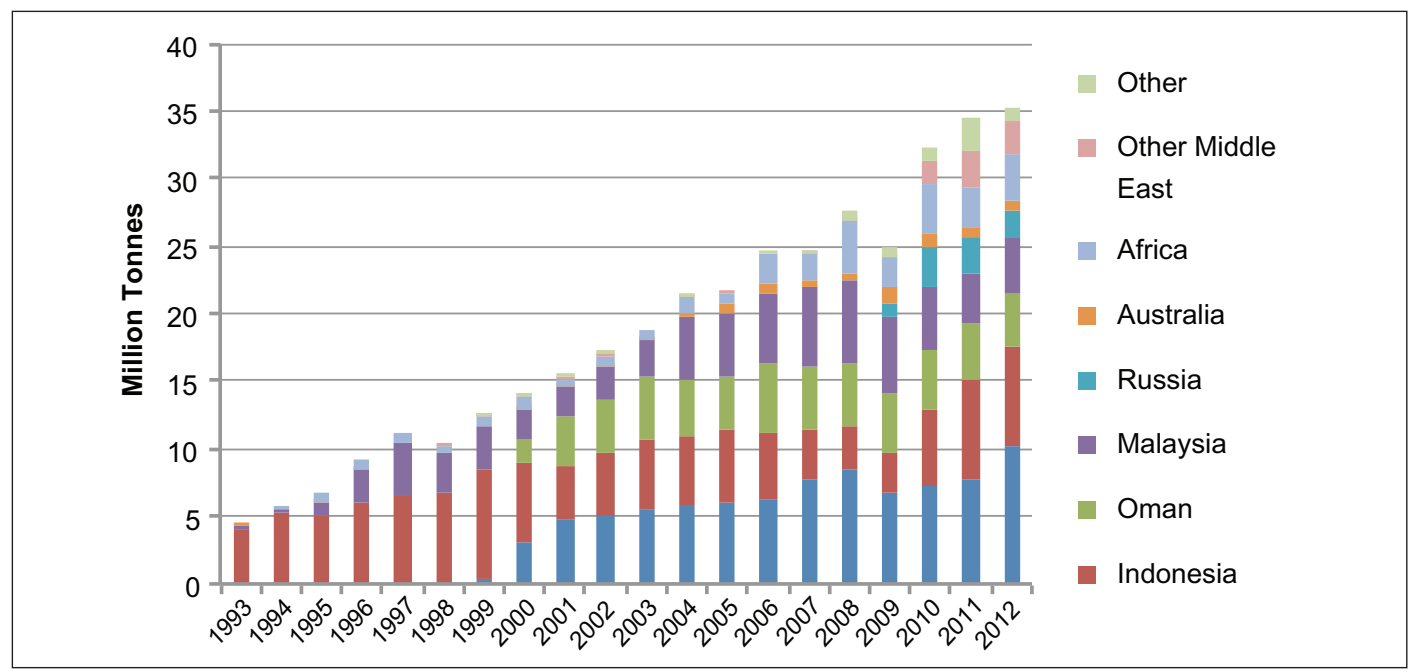

Note: Africa includes Algeria, Brunei, Egypt, Equatorial Guinea, and Nigeria. "Other Middle East" includes the United Arab Emirates and Yemen. "Other" includes Belgium, Japan, Peru, Norway, Spain, Trinidad and Tobago, the United States and "other Asia and Pacific."

Source: IEA, “World - Natural Gas imports by origin," IEA Natural Gas Information Statistics (database), 2013, doi: 10.1787/data-00555-en.

As South Korea grew to become the second-largest LNG importer in the world, KOGAS grew to become the largest individual LNG buyer, making KOGAS a major force in the industry. ${ }^{50}$ The government has made several attempts to break up South Korea's natural gas industry, eliminating KOGAS's monopsony position as South Korea's only LNG buyer, but these reforms have proceeded slowly. ${ }^{51}$ As a result, private companies have the right to import LNG for their own use. Pohang Iron and Steel Corp. (POSCO) and Mitsubishi Japan own the only private LNG import terminal in South Korea. ${ }^{52}$ The 1.7-MMTPA terminal is used by POSCO and SK Corporation to import LNG for their own use. ${ }^{53}$ No other companies have succeeded in building import terminals; KOGAS has retained its role as the dominant LNG importer in South Korea. However, the uncertainty caused by the government's repeated attempts to restructure the industry has led to delays in securing new long-term LNG supplies for the South Korean market. ${ }^{54}$

\footnotetext{
48 IEA, "World - Natural Gas statistics."

49 ibid.

50 EIA website, "Korea, South," http://www.eia.gov/countries/cab.cfm?fips=KS.

${ }^{51}$ IEA, Developing a Natural Gas Trading Hub in Asia (Paris: 2013), 55-56.

52 EIA website, "Korea, South."

53 The Korea Gas Union, "Completion of LNG Terminal in Gwangyang Works," press release, August 11, 2005, http://www.kgu.or.kr/eng/news/industry.html?md=view\&tb=bbs_029\&no=2088\&refer=/eng/news/industry.html?page $=24$.

54 An Tae-Hoon, "Supply and demand trends and plans for natural gas in South Korea," Research Paper (The Institute of Energy Economics, Japan, March 2009), http://eneken.ieej.or.jp/en/report_detail.php?article_info_id=2480.
} 
Natural gas supplies about 16 per cent of South Korea's energy needs, and almost all of that natural gas is imported as LNG. ${ }^{55}$ Whereas two-thirds of Japan's natural gas is consumed for power generation, natural gas use in South Korea is split almost equally between electricity generation (48 per cent in 2011) and residential, commercial and industrial consumers (52 per cent in 2011).$^{56}$ Winters on the Korean peninsula are particularly harsh; as a result, natural gas is an important fuel in the residential and commercial heating market. The demand for natural gas for heating causes very seasonal demand in South Korea, with natural gas demand peaking in winter months. The monthly demand for natural gas is twice as high during the winter months of November through March as it is during the rest of the year. KOGAS has managed this seasonality by constructing additional LNG storage capacity and by purchasing spot cargoes for winter consumption. ${ }^{57}$

With 23 reactors, South Korea has 20.7 GW of nuclear power plants, representing about 22 per cent of South Korea's installed electricity generation capacity, and supplying 29 per cent of total electricity consumption. ${ }^{58}$ Although South Korea was not physically impacted by Fukushima, the nuclear disaster has had repercussions there. Growing concerns over nuclear safety, compounded by the indictment of 100 officials after a probe into the South Korean nuclear industry found widespread use of faked safety documents, has led to calls for a pullback from nuclear power. ${ }^{59}$ In May 2013, the government shut down two reactors found to be using substandard parts and ordered two new reactors to remain off-line pending the completion of parts replacements. ${ }^{60}$

Prior to Fukushima, the government expected LNG consumption for power generation to fall 5.5 per cent per year through 2027 as nuclear power and coal replaced LNG in electricity generation, offsetting an expected 2.7 per cent per year increase in LNG consumption in other sectors. ${ }^{61}$ The government's plans called for nuclear power's contribution to grow to 59 per cent of electricity generated in 2030, from 40 reactors totaling $43 \mathrm{GW}$, accounting for 41 per cent of installed capacity. ${ }^{62}$ In October 2013, the South Korean government proposed that nuclear should account for only 22 to 29 per cent of power generation capacity by $2035 .{ }^{63}$ “"The new long-term energy policy is heavily focused on expanding the use of LNG,' said Jang Gil Soo, a special adviser for Korea Electric Power Corp." ${ }^{64}$ As with Japan, the outlook for LNG demand in South Korea is highly dependent on the future of nuclear power in the country.

\footnotetext{
55 BP, BP Statistical Review (2013).

56 IEA, Natural Gas Information (2013), Table 3A.

57 IEA, Developing a Natural, 55.

58 World Nuclear Association, "Nuclear Power in Korea."

59 ibid.

60 ibid.

${ }^{61}$ Charles Lee, "S Korea's LNG Demand to fall 1.5\% to 38.29 mil mt by 2027: energy ministry," Platts, April 20, 2013, http://www.platts.com/latest-news/natural-gas/seoul/s-koreas-lng-demand-to-fall-15-to-3829-mil-mt-27927622.

62 World Nuclear Association, "Nuclear Power in Korea."

63 Jacob Adelman and James Paton, "Gas Buyers Poised to Commit on South Korea Atomic Shift," Bloomberg, October 16, 2013, http://www.bloomberg.com/news/2013-10-15/gas-buyers-poised-to-commit-on-south-koreaatomic-shift.html.

64 ibid.
} 
Also, like Japan, South Korea is increasingly dependent on LNG supplies from the Middle East, as supplies from other regions have remained stable or declined; in 2012, 47 per cent of South Korea's imports were from the Middle East. ${ }^{65}$ South Korea does not share Japan's historical sensitivities regarding its dependence on imported energy, but it does seek energy security through supply diversity. In 2012, Qatar met almost 29 per cent of South Korea's LNG demand, while the rest of the Middle East and Africa supplied another 28 per cent (Figure A1.7). ${ }^{66}$ KOGAS has equity interests in seven LNG export projects around the world: Oman LNG; Yemen LNG; Qatar LNG; GLNG and Prelude in Australia; DSLNG in Indonesia; and LNG Canada. ${ }^{67}$ KOGAS's foreign investments are part of a corporate growth strategy, but more importantly they represent South Korea's desire to secure resources for the home market.

FIGURE A1.7: SOUTH KOREA'S LNG IMPORTS BY SUPPLY COUNTRY AND REGIONS (2010 - 2012)

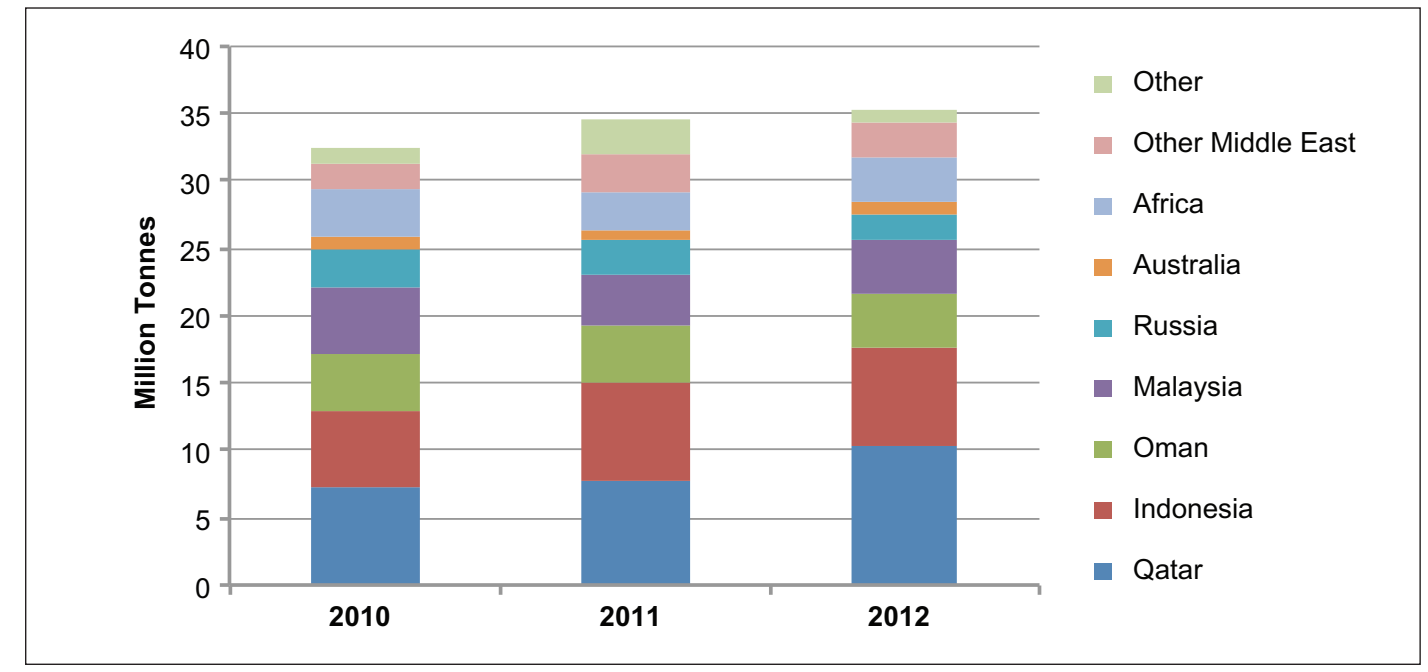

Note: Africa includes Algeria, Brunei, Egypt, Equatorial Guinea, and Nigeria. "Other Middle East" includes the United Arab Emirates and Yemen. "Other" includes Belgium, Peru, Norway, Trinidad and Tobago, and the United States.

Source: IEA, “World - Natural Gas imports by origin,” IEA Natural Gas Information Statistics (database), 2013, doi: 10.1787/data-00555-en.

South Korea is one of the fastest-growing OECD countries, supported by manufacturing, which is fairly energy intensive.$^{68}$ Consumption of natural gas increased 45 per cent between 2009 and 2012, driven in part by economic growth and policies that keep electricity prices low. ${ }^{69}$ PFC Energy expects current growth in natural gas consumption to moderate due to market maturation, lower growth in demand from the power sector, demographics, and improved energy efficiencies. ${ }^{70}$ It should be noted that PFC has not assumed that South Korea's nuclear power expansion plans will be curtailed, which would create additional LNG demand in the longer term.

\footnotetext{
65 IEA, "World - Natural Gas imports."

66 ibid.

67 KOGAS website, "LNG Projects," http://www.kogas.or.kr/en/what/production/lng.action; and LNG Canada website, "LNG Canada," http://lngcanada.ca/lng-canada/.

68 IEA, World Energy Outlook.

69 IEA, "World - Natural Gas statistics"; and IEA, World Energy Outlook, 266.

70 PFC Energy, Global LNG.
} 
The EIA, in its South Korea country analysis, notes that the South Korean government expects natural gas demand to grow at 1.7 per cent per year through $2035 .{ }^{71}$ Current contracts in force mean that the gap between supply and forecast demand does not open up until 2025, at 26.5 BCM or 19.5 MMT (Figure A1.8). The expiry of current long-term contracts will continue, with a gap of 56.6 BCM (41 MMT) in 2035 .

\section{FIGURE A1.8: SOUTH KOREA'S NATURAL GAS SUPPLY-DEMAND BALANCE}

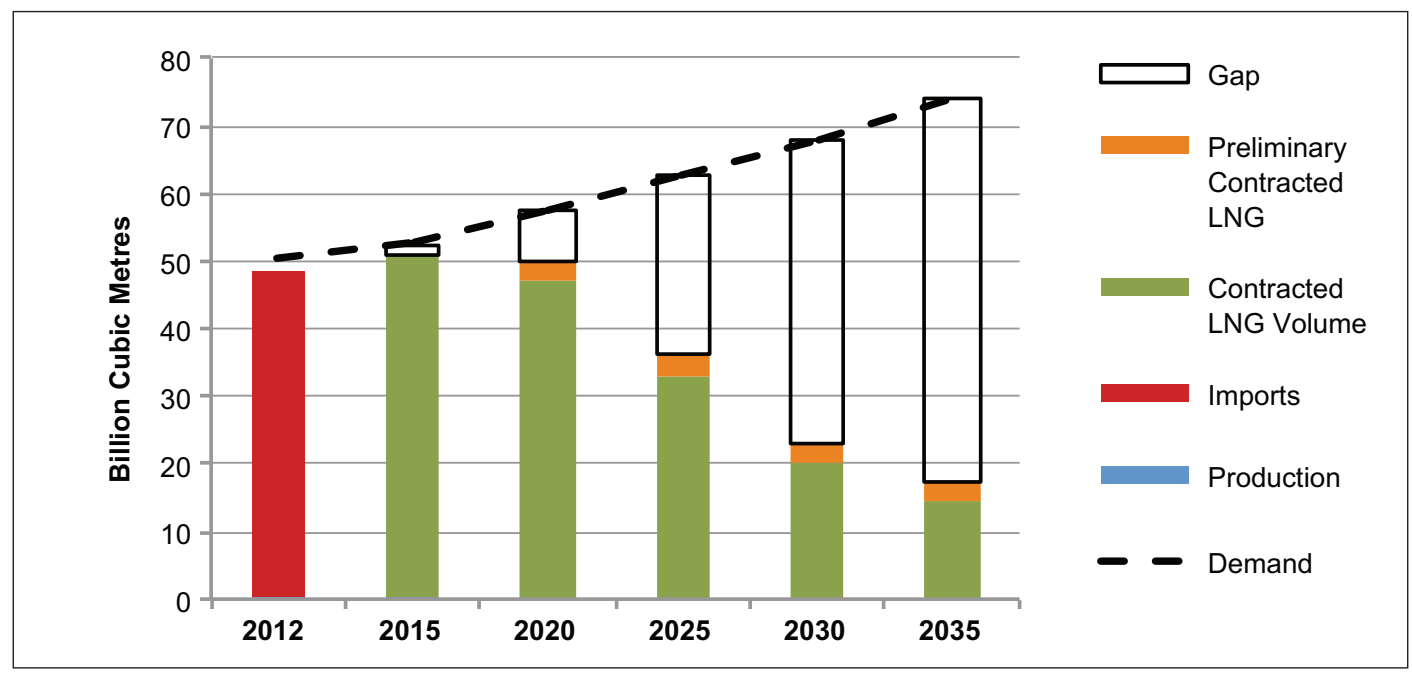

Notes: Production, imports and consumption (demand) data for 2012 from: IEA, “World - Natural Gas statistics," IEA Natural Gas Information Statistics (database), 2013, doi: 10.1787/data-00482-en.

The EIA country analysis for South Korea notes that domestic production will continue until 2018. An annual growth rate of 1.7 per cent for natural gas demand was used (EIA website, "Korea, South,"

http://www.eia.gov/countries/cab.cfm?fips=KS). Contract volumes from Bloomberg POTN (Poten \& Partners) LNG contract database. Contracts defined as preliminary are with projects where no final investment decision has been made for the supplier.

\section{A1.4 TAIWAN}

In many respects, Taiwan is similar to Japan and South Korea, albeit on a much smaller scale. With a population of 23 million, compared to 126 million in Japan and 50 million in South Korea, Taiwan's economy is smaller and its demand for energy is commensurately less. Taiwan's state-owned company, CPC Corp., first imported LNG in $1990 .{ }^{72}$ Since then, Taiwan's LNG imports have grown an average of 17 per cent per year (Figure A1.9). Consumption has grown on average at 12 per cent per year, ${ }^{73}$ driven by the power sector. ${ }^{74}$

\footnotetext{
71 EIA website, "Korea, South."

72 CPC Corp. website, "Downstream Operations," http://en.cpc.com.tw/global_content.aspx?ID=2.

73 IEA, "World - Natural Gas statistics."

74 The power sector's share of natural gas demand has risen from 18 per cent in 1990 to 79 per cent in 2011. Authors' calculations from: IEA, Natural Gas Information.
} 
FIGURE A1.9: TAIWAN'S LNG IMPORTS BY SOURCE COUNTRY AND REGION

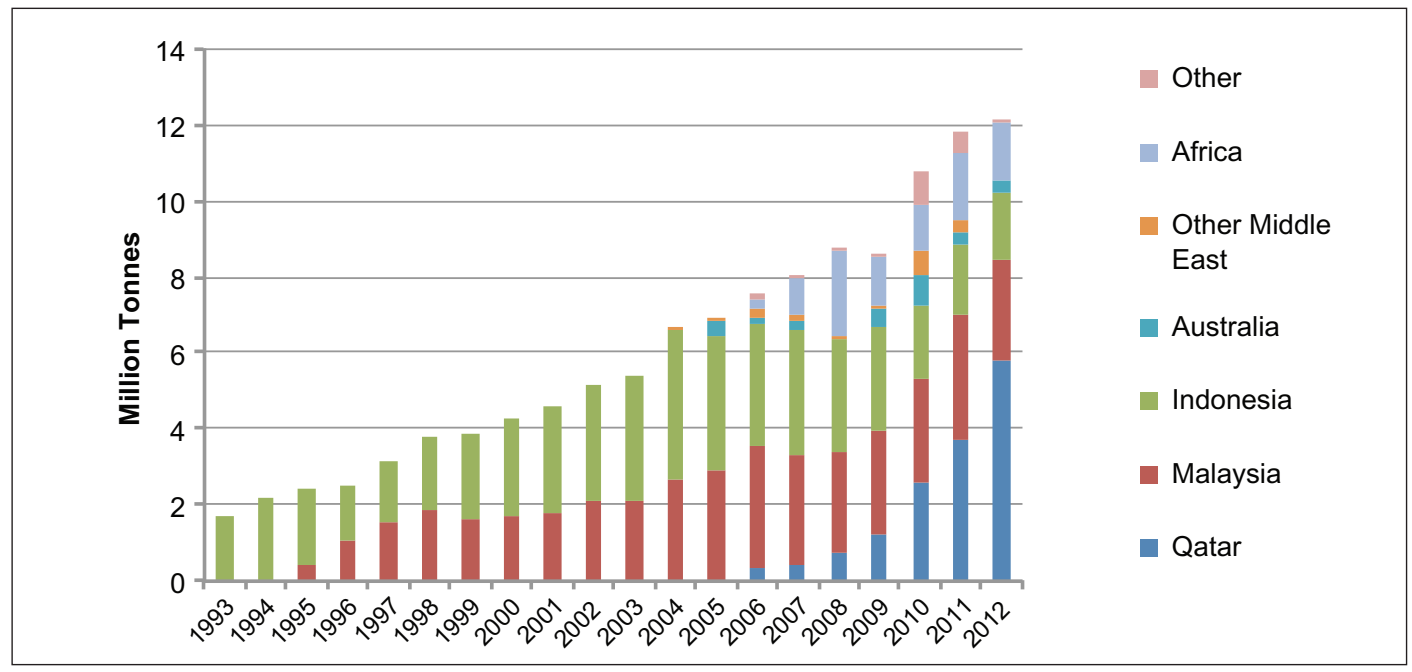

Note: Africa includes Algeria, Egypt, Equatorial Guinea, and Nigeria. “Other Middle East” includes Oman, the United Arab Emirates and Yemen. "Other" includes Norway, Peru, Russia, Trinidad and Tobago, and "non-specified/other."

Source: IEA, “World - Natural Gas imports by origin,” IEA Natural Gas Information Statistics (database), 2013, doi: 10.1787/data-00555-en.

Following a similar path as Japan and South Korea, Taiwan had plans to increase its nuclear power generation in preference to additional fossil fuel power plants. ${ }^{75}$ However, in the aftermath of the Fukushima incident, nuclear power has emerged as a contentious issue. Active seismic faults run across the island, and some argue that Taiwan is unsuited for nuclear plants. Protesters have demonstrated for an immediate halt to the use of nuclear power in Taiwan. ${ }^{76}$ The public's faith in the safety of nuclear power was shaken after leaks were found in pools of used nuclear fuel at an operating plant. ${ }^{77}$ As noted in a report from Bloomberg, "President Ma Ying-jeou has said that atomic energy will be abandoned as soon as economically and environmentally viable alternatives are found." 78

However, given the low cost of nuclear power (US\$0.019/kWh in 2008), it is unlikely that existing nuclear plants will be shut down before the end of their 40-year operating lives in the absence of a significant incident. ${ }^{79}$ In the absence of a change in energy policy, Taiwan's LNG demand can be expected to continue to grow steadily. Taiwan will remain an attractive target market for LNG sellers, but as a buyer of relatively small incremental quantities it is unlikely to play a major role in the launch of new projects.

\footnotetext{
75 Taiwan has six reactors currently operating, with two additional reactors under construction. World Nuclear Association website, "Nuclear Power in Taiwan," http://www.world-nuclear.org/info/CountryProfiles/Others/Nuclear-Power-in-Taiwan/.

76 Lee I-chia, "More than 100,000 protest over nuclear power plants," Taipei Times, March 9, 2014, http://www.taipeitimes.com/News/front/archives/2014/03/09/2003585210.

77 Faith Hung, "Taiwan says nuclear plant may have leaked toxic water," Reuters, August 9, 2013, http://www.reuters.com/article/2013/08/09/us-taiwan-nuclear-idUSBRE97803Y20130809.

78 Adelman and Paton, "Gas Buyers"

79 World Nuclear Association, "Nuclear Power in Taiwan."
} 
Taiwan's sole importer, CPC, has long-term contracts in place with Australia, Indonesia, Malaysia and Qatar, totaling 15.04 MMTPA. ${ }^{80}$ Additional contracts with Australia, Papua New Guinea and the United States will begin in 2017, 2015 and 2016, respectively. In 2012 Qatar met over 47 per cent of Taiwan's LNG demand, while Malaysia contributed almost 22 per cent and Indonesia almost 15 per cent. $^{81}$

FIGURE A1.10: TAIWAN'S LNG IMPORTS BY SUPPLY COUNTRY AND REGION (2010 - 2012)

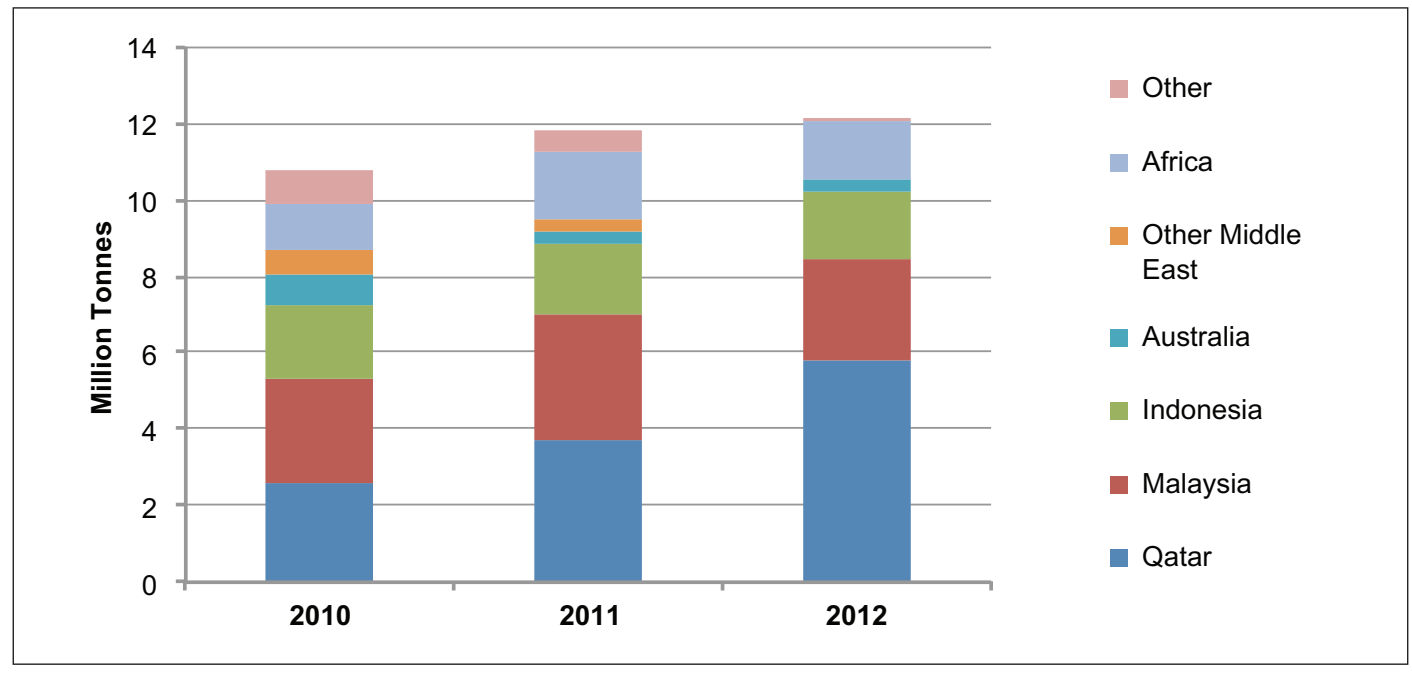

Note: Africa includes Algeria, Egypt, Equatorial Guinea, and Nigeria. "Other Middle East" includes Oman, the United Arab Emirates and Yemen. "Other" includes Norway, Peru, Russia, Trinidad and Tobago, and "non-specified/other."

Source: IEA, “World - Natural Gas imports by origin,” IEA Natural Gas Information Statistics (database), 2013, doi: 10.1787/data-00555-en.

PFC Energy expects LNG demand to grow to meet increasing electricity demand and to offset declining nuclear power output as plants are taken off-line at the end of their 40-year operating lives. ${ }^{82}$ This would leave only Taiwan's newest nuclear plant, scheduled to start up in 2014, in operation in 2030. PFC Energy forecasts Taiwan's demand for natural gas to reach 20 MMT (27.2 BCM) by 2030, equivalent to a compound annual growth rate of 2.7 per cent. The lack of official forecast from the IEA or the EIA for Taiwan's natural gas demand makes determining a supply-demand balance somewhat difficult. We use a slightly more conservative forecast of two per cent per year demand growth in Figure A1.11.

Taiwan has secured at least 13 MMTPA of LNG from 2015 to 2030, providing the market with a base supply until contracts begin expiring in 2033. ${ }^{83}$ Taiwan will need to turn to the spot market, as it has in the past, for a large share of LNG, or sign new long-term contracts (Figure A1.11). In 2020, the gap between contracted supply and demand will reach 6 MMTPA, by 2025 it will reach 8 MMTPA, and by 2030 it will grow to 11 MMTPA. Long-term agreements with Indonesia and Qatar may be extended, but this would still leave Taiwan with a sizable supply-demand gap that would need to be met. ${ }^{84}$

\footnotetext{
80 Bloomberg POTN (Poten \& Partners) LNG Contract Database.

81 IEA, "World - Natural Gas imports."

82 PFC Energy, Global LNG.

83 Bloomberg POTN (Poten \& Partners) LNG Contract Database.

84 PFC Energy, Global LNG.
} 
FIGURE A1.11: TAIWAN'S NATURAL GAS SUPPLY-DEMAND BALANCE

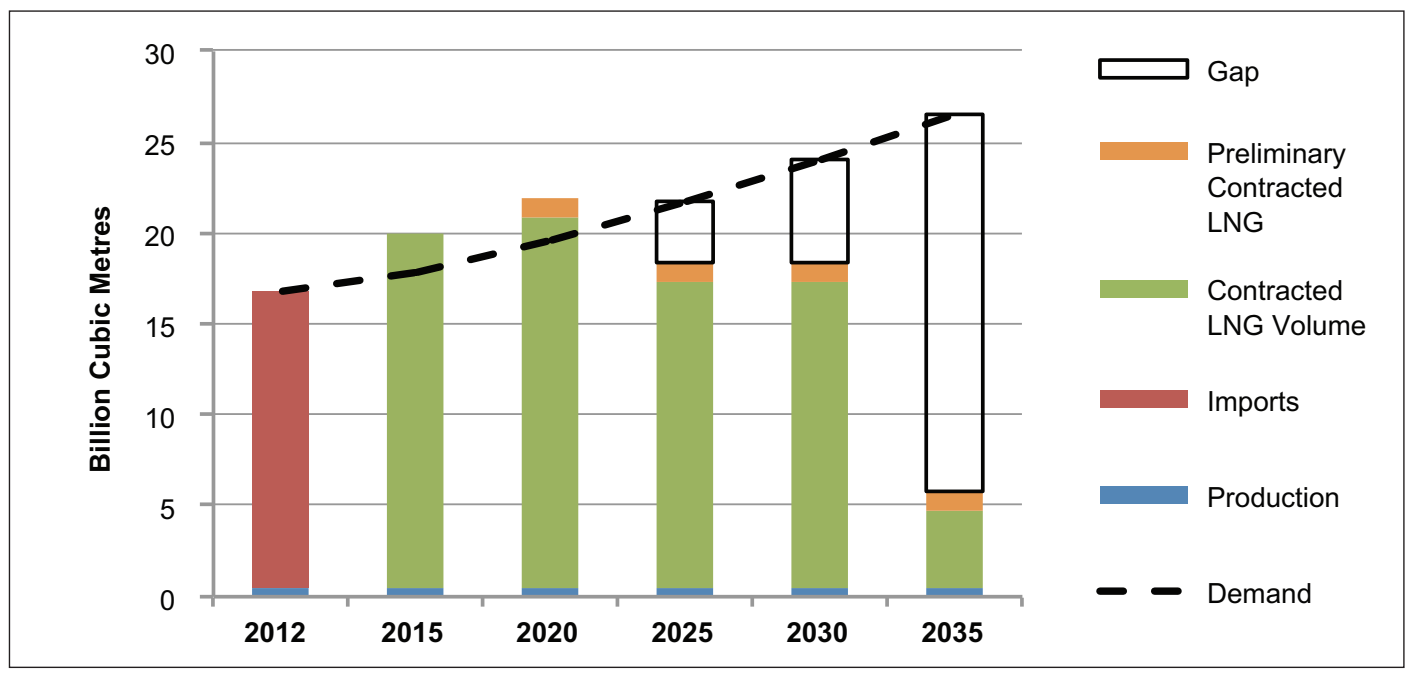

Notes: Production, imports and consumption (demand) data for 2012 from IEA, "World - Natural Gas statistics," IEA Natural Gas Information Statistics (database), 2013, doi: 10.1787/data-00482-en. Production assumed to continue at 2012 volumes. An annual growth rate of two per cent for natural gas demand was used. Contract volumes from Bloomberg POTN (Poten \& Partners) LNG contract database. Contracts defined as preliminary are with projects where no final investment decision has been made for the supplier.

\section{A2 Non-traditional LNG Buyers: China and India}

\section{A2.1 CHARACTERISTICS OF NON-TRADITIONAL LNG BUYERS}

Globally, the centre of natural gas demand has been shifting from developed economies toward developing, or emerging economies. This is also true of the Asia-Pacific region. China and India, and other recent entrants to the LNG market, are often referred to as "non-traditional" or "emerging" LNG markets. These are typically less-developed economies with low gas-market penetration, less affluent, more price-sensitive consumers, and a short and untested history of importing LNG. The presence of greater domestic production and regulation of internal gas prices, combined with the potential for overland pipeline imports, make China and India very different buyers. ${ }^{85}$ LNG suppliers and financiers view the commercial risk profile of nontraditional buyers to be greater, but recognize that continued growth of the industry is dependent on these buyers.

However, the rapid economic development in non-traditional markets, particularly in China, is blurring the distinction between traditional and non-traditional LNG buyers. China, by virtue of its size, high economic growth rate, and virtually insatiable demand for energy to feed its economic growth, stands apart from other non-traditional LNG buyers. India, already an important buyer of LNG, has struggled to deal with recent unexpected domestic production declines resulting in increased reliance on LNG, as well as the inherently high cost of LNG. ${ }^{86}$

\footnotetext{
85 For details on price regulation, see: Stern, The Pricing, Chapters 9 and 10.

${ }^{86}$ EIA website, "Country Analysis - India," http://www.eia.gov/countries/cab.cfm?fips=IN.
} 


\section{A2.2 CHINA}

The dominance of the Japanese-South Korean-Taiwanese troika in the Asia-Pacific LNG market started to erode when China entered the LNG market with the signing of its first LNG contract for 3.7 MMTPA with Australia's North West Shelf (NWS) LNG Project. ${ }^{87}$ China subsequently signed a contract with the Tangguh LNG Project in Indonesia for 2.6 MMTPA. China did not import any natural gas until 2006, when it imported 1.0 MMT of LNG into its Guangdong-Dapeng import terminal under its contract with Australia's NWS (Figure A2.1). In only six years, China's LNG imports have grown to just over 14 MMTPA (almost 20 BCM per year).

FIGURE A2.1: CHINA'S LNG IMPORTS BY SOURCE COUNTRY

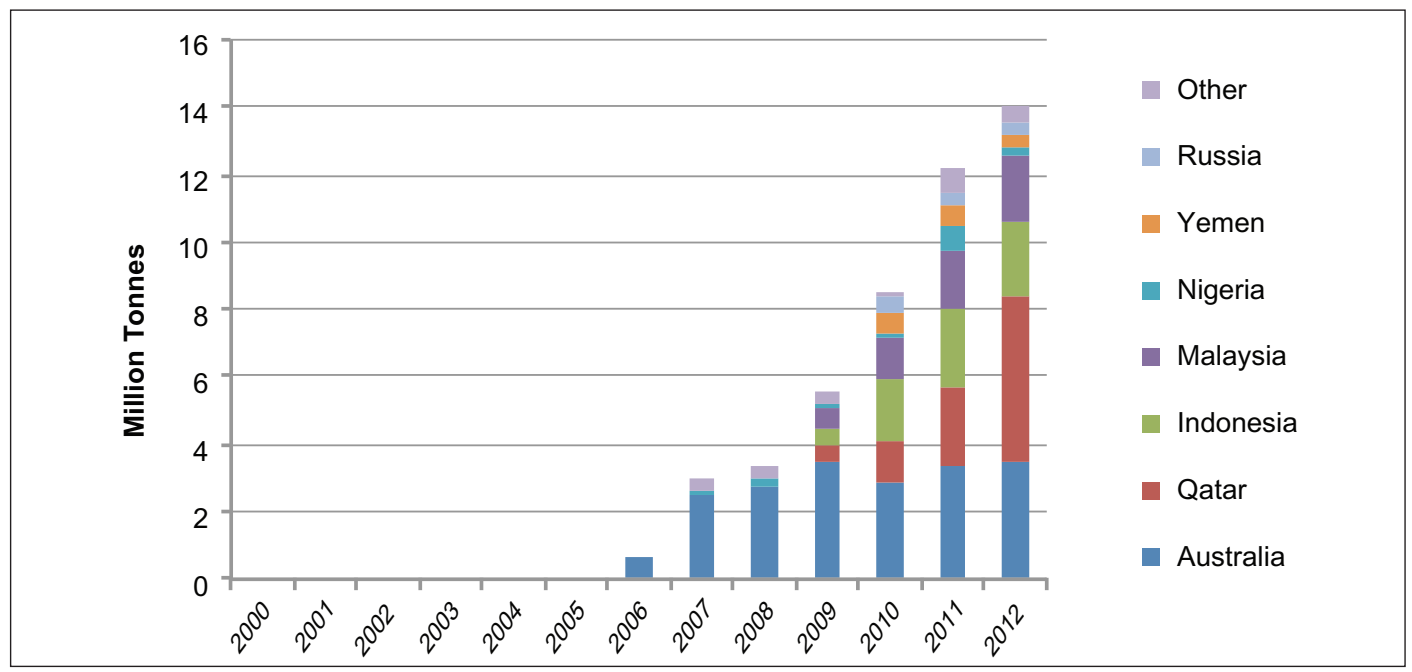

Note: "Other" includes Algeria, Equatorial Guinea, Oman, Peru, the United States, and "non-specified/other."

Source: IEA, "World - Natural Gas imports by origin," IEA Natural Gas Information Statistics (database), 2013, doi: 10.1787/data-00555-en.

China has six receiving terminals with a combined capacity of about 24 MMTPA..$^{88}$ In addition, China has six new terminals under construction, with a combined import capacity of 17.5 MMTPA, that will become operational by the end of $2017 .{ }^{89}$ Planned expansions of existing terminals and terminals under construction will add about 30 MMTPA of capacity. Three statecontrolled companies have been charged with constructing import terminals and importing LNG: China National Offshore Oil Corp. (CNOOC); PetroChina Company Ltd. (PetroChina), the listed arm of state-owned China National Petroleum Corp. (CNPC); and Sinopec Ltd. (Sinopec), the listed arm of China Petroleum and Chemical Corp. ${ }^{90}$

87 Bloomberg POTN (Poten \& Partners) LNG Contract Database.

88 GIIGNL, The LNG Industry in 2013 (Paris: GIIGNL, 2013); Bloomberg, "China’s Liquefied Natural Gas Terminals," August 16, 2012, http://www.bloomberg.com/news/2012-08-16/china-s-liquefied-natural-gas-terminals-table-html; Song Yen Ling, "China's CNOOC receives first LNG cargo at Tianjin FSRU," Platts, November 26, 2013, http://www.platts.com/latest-news/natural-gas/singapore/chinas-cnooc-receives-first-lng-cargo-at-tianjin-27666510.

89 For sources, see: Appendix F.

90 Petroleum Economist, World LNG Factbook (London: Euromoney, 2013). 
When China opened to foreign investment in the oil and gas industry, CNOOC was incorporated and given overall responsibility for the exploitation of China's offshore resources in co-operation with foreign partners. ${ }^{91}$ When China decided to start importing LNG, the government turned to $\mathrm{CNOOC}$, with its experience with foreign joint ventures, to lead China into this unfamiliar area of international trade. As a consequence, CNOOC was the first to construct an import terminal in China, in a joint venture with a foreign partner, and continues to lead China in the construction of new terminals and in the purchase of LNG. ${ }^{92}$

FIGURE A2.2: CHINA'S LNG IMPORT TERMINAL CAPACITY BY OPERATOR

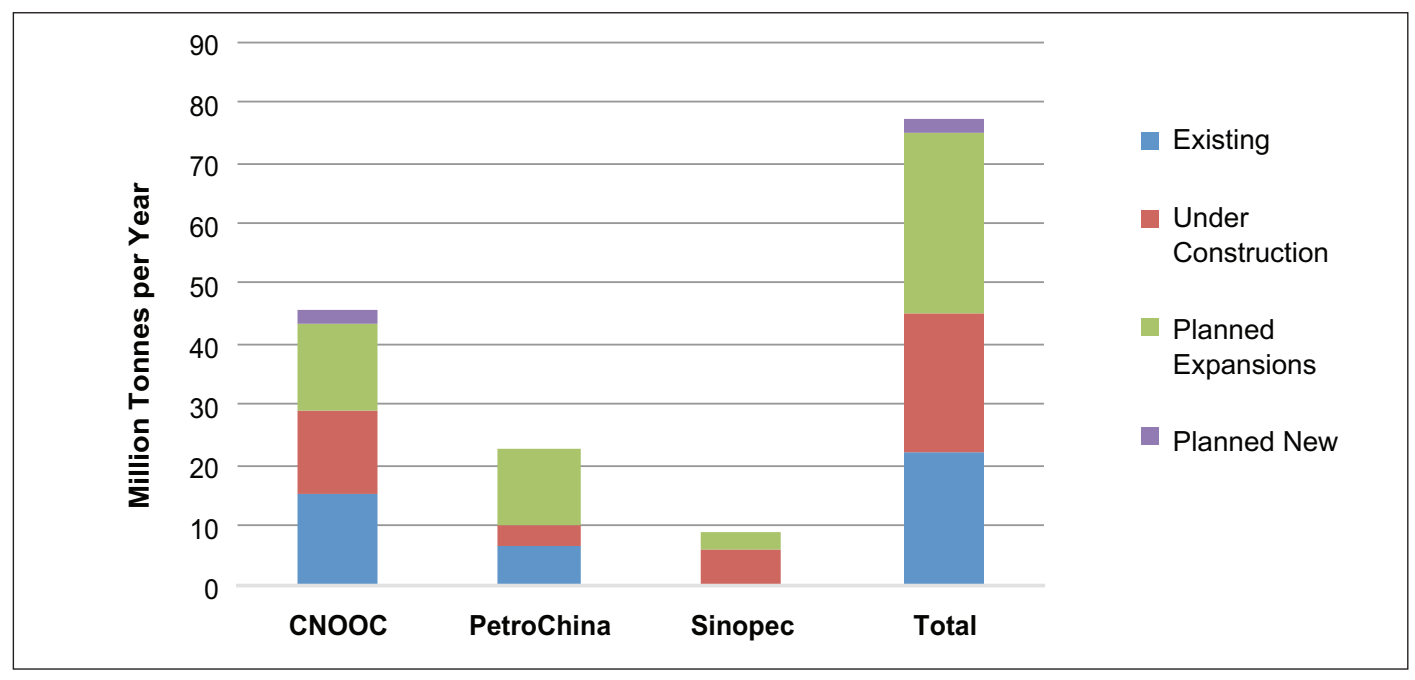

Source: Petroleum Economist, World LNG Factbook (London: Euromoney, 2013).

China features certain characteristics that make it unique among Asia-Pacific LNG buyers:

- With a population of 1.3 billion, and high economic growth rates,${ }^{93}$ China's potential demand for energy, and LNG, dwarfs that of other LNG buyers in the Asia-Pacific region.

- China has significant, indigenous natural gas resources. China has conventional gas resources, coal-bed methane (CBM) and, potentially, the largest resources of shale gas in the world. ${ }^{94}$

- As China's gas market is based on domestic pipeline gas, rather than on rich LNG, China has no need for LNG with high heating values. ${ }^{95}$ China is, therefore, a prime target market for LNG exported from North America and Australia.

- China has significant gas-on-gas competition. Within the Asia-Pacific region, only China has the potential to import significant new supplies of natural gas via pipelines from multiple suppliers. ${ }^{96}$ China can use its gas supply options as negotiating leverage with pipeline gas and LNG sellers.

\footnotetext{
91 CNOOC website, “Our History,” http://en.cnooc.com.cn/data/html/english/channel_114.html.

92 EIA website, "China," http://www.eia.gov/countries/cab.cfm?fips=ch.

93 CIA World Factbook, "China," https://www.cia.gov/library/publications/the-world-factbook/geos/ch.html.

94 EIA website, "China."

95 For a discussion of natural gas characteristics, see: Appendix B; Table B1 reports calorific values for produced, imported and consumed gas for each country.

96 EIA website, "China."
} 
- China has three large state-owned oil and gas companies, each of which can buy foundation-buyer quantities of LNG. ${ }^{97}$ This gives China significant negotiating leverage with sellers.

- While notionally independent and in commercial competition with each other, CNOOC, Petrochina, and Sinopec each operate within the sphere of government direction, control and support.

- China can buy LNG "opportunistically." While other LNG buyers go to the market when they have demand for LNG, China's supply options mean it can buy LNG when it is able to negotiate favourable commercial terms.

In 2012, China imported LNG from nine countries, which contributed 50 per cent of China's natural gas imports, and met 27 per cent of China's natural gas demand. ${ }^{98}$ Qatar supplied 34 per cent of China's LNG, while 29.7 per cent came from Southeast Asia, and over 25 per cent came from Australia. ${ }^{99}$

FIGURE A2.3: CHINA'S LNG IMPORTS BY SUPPLY COUNTRY (2010 - 2012)

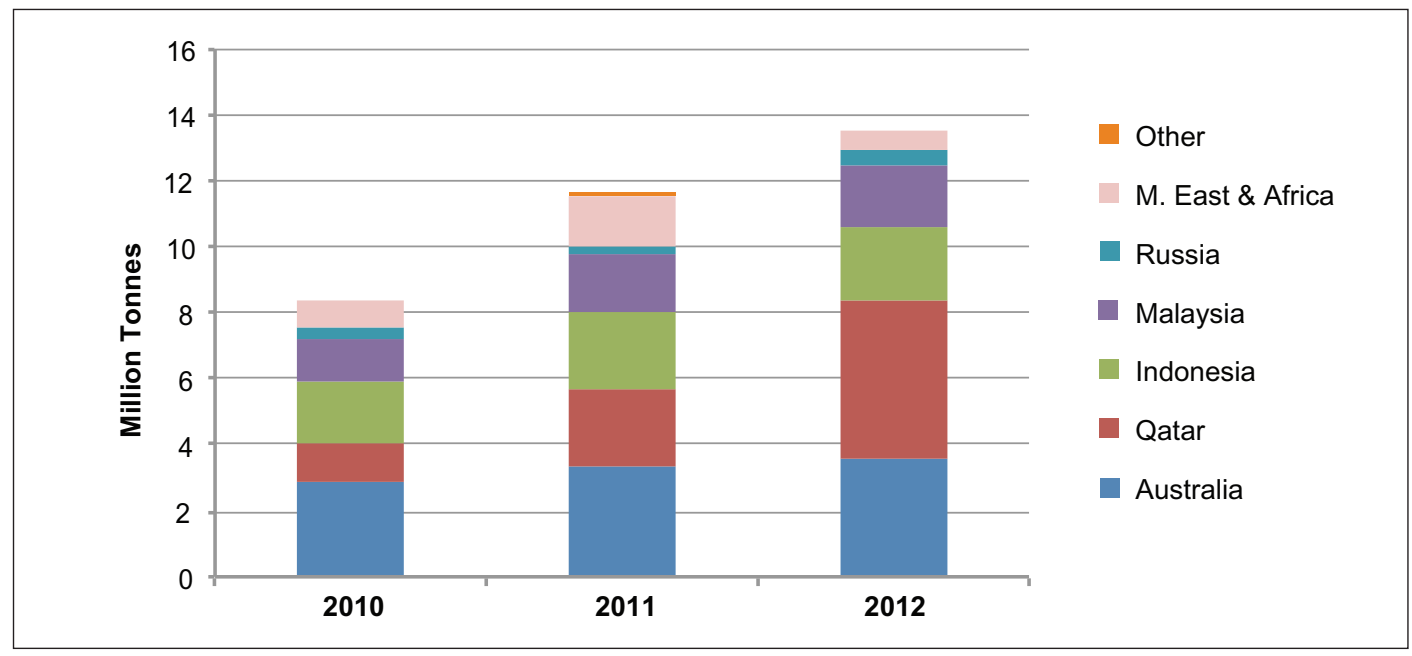

Note: Africa and Middle East includes Equatorial Guinea, Nigeria and Yemen. "Other" includes Peru and the United States.

Source: IEA, "World - Natural Gas imports by origin," IEA Natural Gas Information Statistics (database), 2013, doi: 10.1787/data-00555-en.

Fortuitously, or perhaps by design, China entered the LNG market during a "buyer's market" in the early 2000s. ${ }^{100}$ China was also able to achieve other state goals, including technology transfer in the construction and operation of import terminals and LNG ships, mandates to use Chinesebuilt LNG ships, and significant equity participation in upstream projects. As a legacy of securing very low prices in its first two LNG contracts, the average price China paid for LNG has been substantially lower than prices in Japan. ${ }^{101}$ It remains to be seen whether past success and the significant negotiating leverage wielded by "China Inc." will allow CNOOC, PetroChina and Sinopec to continue to secure LNG supplies on "better-than-market" commercial terms.

97 Based on Bloomberg's LNG Contract Database, the three SOEs currently hold the only long-term contracts for delivery to China.

98 IEA, "World - Natural Gas imports."

99 ibid.

${ }^{100}$ Andy Flower and June Liao, "LNG Pricing in Asia," in The Pricing ed. Stern, Chapter 11.

${ }^{101}$ ibid. 
China's natural gas resources are mostly onshore, but distant from large population and industrial centres on the East Coast. LNG imports primarily serve the developed provinces along the coast, from Guangdong in the south to Liaoning in the north. China has historically been a net exporter of natural gas, though in 2007, domestic consumption exceeded production for the first time. ${ }^{102}$

In 2012 China produced 107.2 BCM of natural gas (a 55 per cent increase from 2007), and imported 38.4 BCM, of which 50 per cent was imported through the 1,833-kilometre Turkmenistan-Uzbekistan-Kazakhstan pipeline or Central Asian Gas Pipeline (CAGP). ${ }^{103}$ Virtually all of the gas imported through the CAGP pipeline comes from Turkmenistan, making Turkmenistan China's largest natural gas supplier. In 2012, China's natural gas imports from Turkmenistan were almost three times as much as imports from Qatar in the form of LNG. ${ }^{104}$ China's pipeline gas imports are set to increase significantly when additional phases of the CAGP begin operations, and as the China-Myanmar pipeline ramps up to full capacity. ${ }^{105}$

China started importing natural gas from Myanmar in 2013 through a 793-kilometre pipeline with a capacity of $12 \mathrm{BCM}$ per year. ${ }^{106}$ China's CNPC has also signed a "framework agreement" with Russia's Gazprom for the import of 36.8 BCM per year of natural gas from Russia through the proposed East Siberia pipeline. ${ }^{107}$ The deal was recently concluded and is reported to be a 30 -year contract to supply $38 \mathrm{BCM}$ of natural gas per year via pipeline, with deliveries starting in 2018, and a price of US\$353/MCM (US\$10/MCF). ${ }^{108}$

CNOOC, PetroChina and Sinopec have sought participation in LNG projects around the world. CNOOC leveraged its LNG purchases from Australia's NWS project and Indonesia's Tangguh project to acquire equity interests in those projects. ${ }^{109} \mathrm{CNOOC}$ also leveraged its LNG purchase from the Queensland Curtis LNG coal-bed methane (CBM) projects to acquire an equity stake. ${ }^{110} \mathrm{CNOOC}$ is developing at least two Canadian LNG projects through its wholly owned subsidiaries, Nexen Energy ULC ${ }^{111}$ and CNOOC Gas and Power Group. ${ }^{112}$

\footnotetext{
102 IEA, "World - Natural Gas statistics."

${ }^{103}$ Ibid.; and IEA, "World - Natural Gas imports."

104 ibid.

${ }^{105}$ EIA website, "China."

${ }^{106}$ EIA website, "China."

107 ibid.

${ }^{108}$ Yadullah Hussain, “China and Russia’s US\$400-billion natural gas deal “complicates' new LNG projects,” National Post, May 21, 2014.

109 Australia LNG, “CNOOC Equity Agreement,” news release, December 20, 2004, http://www.nwsalng.com.au/news/2004/CNOOC-EQUITY-AGREEMENT; and CNOOC, "CNOOC Limited Acquires Additional Equity Interest in the Tangguh LNG Project," news release, February 2, 2004, http://www.cnoocltd.com/encnoocltd/newszx/news/2004/793.shtml.

110 CNOOC, "CNOOC and BG Group Sign Agreements for New LNG Supply and Purchase of QCLNG Stake," news release, May 6, 2013, http://en.cnooc.com.cn/data/html/news/2013-05-06/english/338442.html

111 Brent Jang, "CNOOC heads group seeking to export B.C. liquefied natural gas," The Globe and Mail, November 29, 2013.

112 Jeff Lewis, "CNOOC subsidiary to partner with U.K. firm on Prince Rupert LNG Terminal," National Post, April 23, 2014.
} 
Similarly, Sinopec leveraged its LNG purchase from Australia Pacific LNG (APLNG), a CBMto-LNG project. ${ }^{113}$ Sinopec also recently joined Petronas with a stake in the Pacific Northwest LNG project in Canada. ${ }^{114}$ PetroChina is a partner with Shell in Arrow LNG, another Australian CBM joint-venture project. ${ }^{115}$ PetroChina is also a participant in the LNG Canada joint venture with Shell, KOGAS and Mitsubishi. ${ }^{116}$

Natural gas is consumed in almost every sector in China. Economic growth has driven energy demand: natural gas consumption has increased 3,693 per cent since 1971, and 745 per cent since 1993. ${ }^{117}$ Despite these immense increases, natural gas still contributes less than five per cent of China's primary energy consumption. ${ }^{118}$ The power sector has only recently become a major component of natural gas demand, but new gas-fired power plants are the anchor customers for imported LNG. ${ }^{119}$

Despite growing domestic production of natural gas and increasing pipeline gas imports, PFC Energy expects that China will become one of the world's largest LNG markets. PFC indicates that China's LNG demand could grow to 50 MMTPA (68 BCM) by $2020 .{ }^{120}$ The EIA predicts that China's natural gas demand will increase at four per cent per year, reaching 220.7 BCM in 2020. The IEA forecast is a little more optimistic, predicting natural gas demand to grow at six per cent per year under the New Policies Scenario, reaching 307 BCM in 2020. ${ }^{121}$

Figure A2.4 shows China's projected supply-demand balance to 2035. Existing LNG contracts will provide China with 47.8 MMT (65 BCM) of LNG in 2020. ${ }^{\text {I22 }}$ PFC Energy projects a natural gas supply-demand gap of $15 \mathrm{BCM}$ in 2020, which will be met by LNG and/or pipeline imports. ${ }^{123}$ However, pipeline capacity into China in 2020 is projected to be $139.5 \mathrm{BCM}$, with the completion of the Central Asian Gas Pipeline's Line C and Line D, ${ }^{124}$ and the addition of the Russia-China pipeline. ${ }^{125}$ With these pipeline capacity additions and currently existing contract volumes, supply to China is greater than demand until 2030. However, if supply contracts for pipeline gas are less than capacity, there is potential for a supply-demand gap after 2020 .

\footnotetext{
113 ConocoPhillips, “Australia Pacific LNG \& Sinopec Sign Binding Agreements for LNG Supply \& 15\% Equity Interest," news release, April 21, 2011, http://www.conocophillips.com.cn/EN/newsroom/newsreleases/Pages/Articles/australia-pacific-lng-sinopec-sign-binding-agreements-for-lng-supply-15-percent-equityinterest.aspx.

${ }^{114}$ Brent Jang, "China's Sinopec to become fourth partner in B.C. LNG project,” The Globe and Mail, April 29, 2014.

115 James Paton and Aibing Guo, "PetroChina Looks to Add to \$3.7 Billion in Australian Deals," March 10, 2013, Bloomberg, http://www.bloomberg.com/news/2013-03-10/petrochina-looks-to-add-to-3-7-billion-in-australiandeals.html.

${ }^{116}$ LNG Canada website, “The Companies Behind LNG Canada," http://nngcanada.ca/the-project/the-companies-behindlng-canada/.

${ }^{117}$ IEA, "World - Natural Gas statistics."

118 BP, BP Statistical Review (2013).

${ }^{119}$ EIA website, "China."

${ }^{120}$ PFC Energy, Global LNG.

${ }^{121}$ IEA, World Energy Outlook.

${ }^{122}$ Bloomberg POTN (Poten \& Partners) LNG Contract Database.

${ }^{123}$ PFC Energy, Global LNG.

${ }^{124}$ EIA website, "China."

${ }^{125}$ Hussain, "China and Russia's."
} 
FIGURE A2.4: CHINA'S NATURAL GAS SUPPLY-DEMAND BALANCE

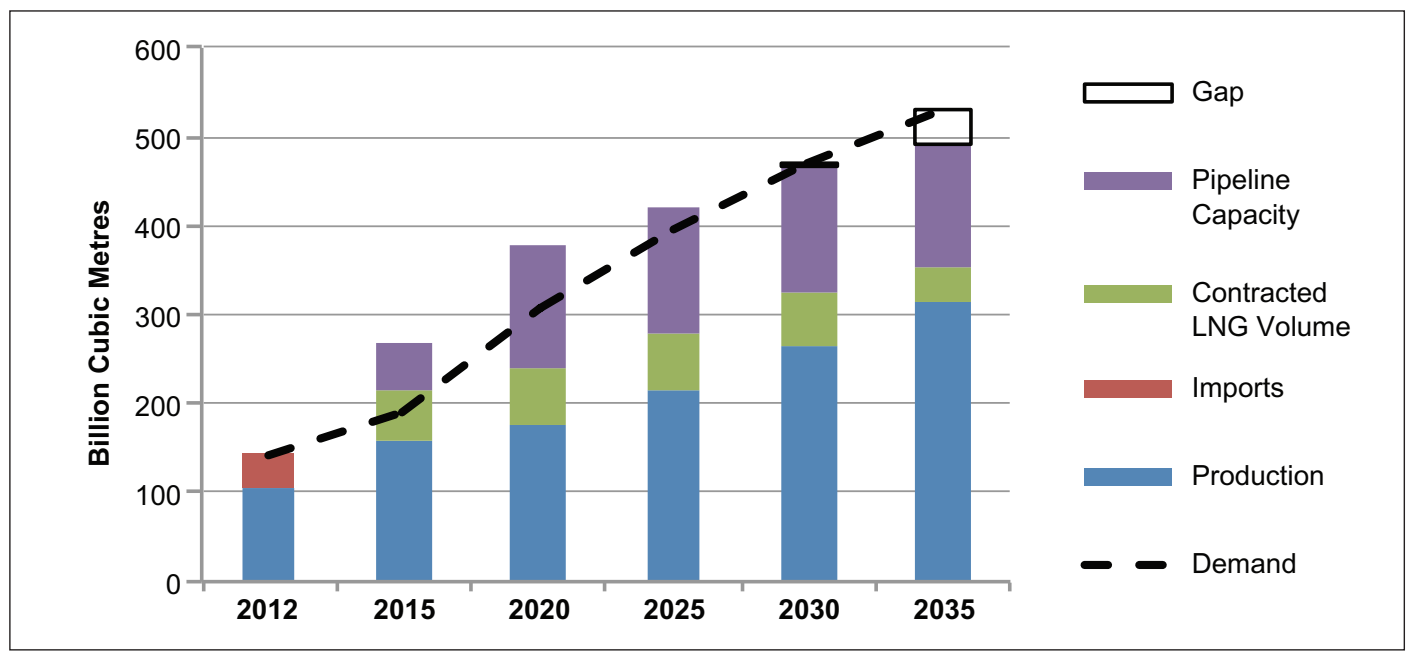

Notes: Production, imports and consumption (demand) data for 2012 from IEA, "World - Natural Gas statistics," IEA Natural Gas Information Statistics (database), 2013, doi: 10.1787/data-00482-en. Production and consumption forecasts from IEA, World Energy Outlook (Paris: OECD/IEA, 2013). Natural gas exports assumed to continue at 2012 volumes. Contract volumes from Bloomberg POTN (Poten \& Partners) LNG contract database. Pipeline capacity from EIA website, “China," http://www.eia.gov/countries/cab.cfm?fips=ch.

\section{A2.2 INDIA}

India has the 10th-largest economy in the world ${ }^{126}$ and is the third-largest energy consumer after the U.S. and China, and ahead of Russia. ${ }^{127}$ India's economy has grown (on average) 12.7 per cent per year between 2000 and 2011, while primary energy consumption has grown about 4.4 per cent per year. ${ }^{128}$ Natural gas consumption grew 117 per cent between 2000 and 2011, an average of seven per cent per year. ${ }^{129}$ In 2011 , the natural gas share of primary energy demand was only seven per cent, and only five per cent of total final consumption. ${ }^{130}$ The country was self-sufficient in natural gas until 2003, when it began to import LNG from Qatar. LNG has become steadily more important in supporting domestic consumption, increasing from a share of one per cent in 2003 to 30 per cent of consumption in 2012. ${ }^{131}$

\footnotetext{
${ }^{126}$ Based on 2011 and 2012 GDP, in current U.S. dollars. World Bank, "GDP (current US\$)," http://data.worldbank.org/indicator/NY.GDP.MKTP.CD.

${ }^{127}$ Based on 2011 energy use (KT of oil equivalent). World Bank, "Energy use (kt of oil equivalent)," http://data.worldbank.org/indicator/EG.USE.COMM.KT.OE/countries.

${ }^{128}$ Authors' calculations, from: World Bank, ““'GDP”; and World Bank, “Energy use.”

${ }^{129}$ Authors' calculations, based on: IEA, "World - Natural Gas statistics."

${ }^{130}$ IEA, World Energy Outlook, Appendix A, 624.

${ }^{131}$ Authors' calculations, based on: IEA, "World - Natural Gas statistics"; and IEA, "World - Natural Gas imports."
} 


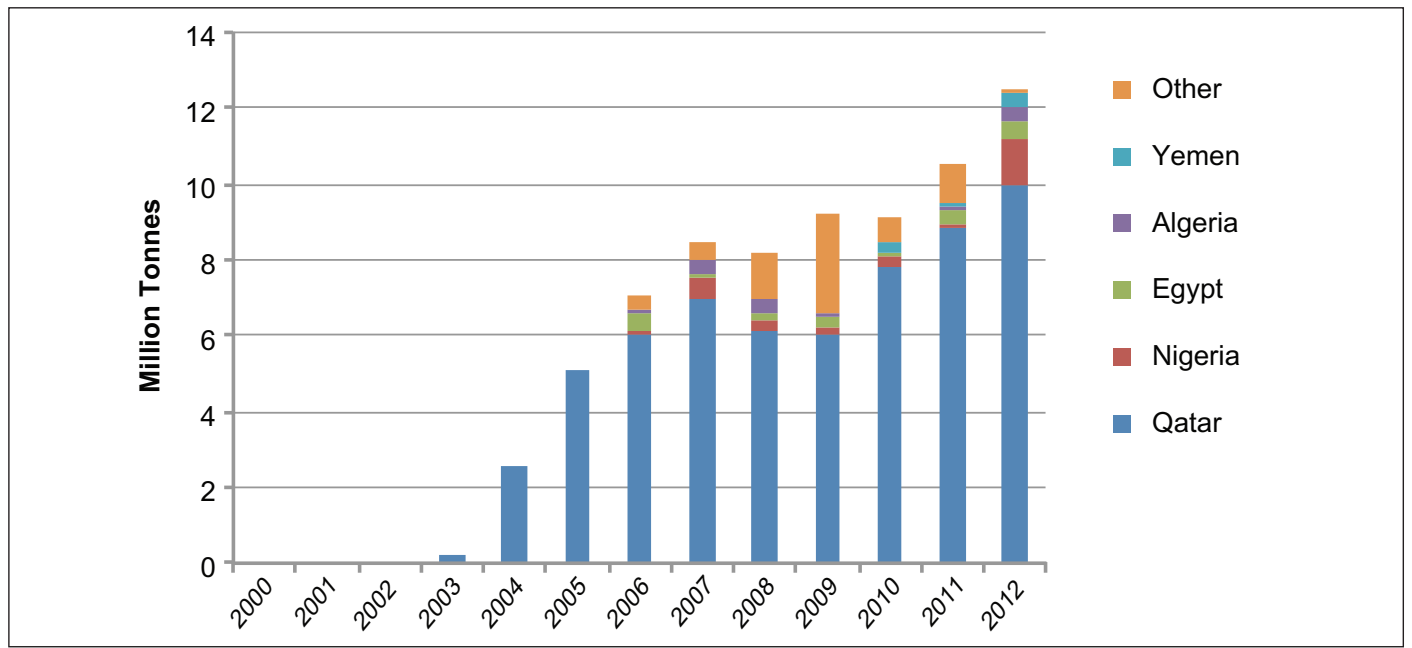

Note: "Other" includes Australia, Equatorial Guinea, Indonesia, Malaysia, Norway, Oman, Trinidad and Tobago, the United Arab Emirates, the United States and "non-specified/other."

Source: IEA, “World - Natural Gas imports by origin," IEA Natural Gas Information Statistics (database), 2013, doi: 10.1787/data-00555-en.

The focus of India's energy policy is securing energy sources to meet the needs of its growing economy. ${ }^{132}$ Inconsistent energy-sector reform combined with domestic fuel subsidies and import dependency compromise the ability of the government to secure supplies; however, the government has announced a plan to make India energy independent by $2030 .{ }^{133}$ India is a price-sensitive buyer of LNG, which cannot compete in price-controlled sectors of India's natural gas economy. Price reforms are underway, which, if implemented, could allow for greater penetration of natural gas into sectors other than power generation. ${ }^{134}$

India's path to LNG imports has been long and tortuous - a cautionary tale for LNG sellers. The country's first LNG import terminal was to be constructed by Enron in the early 2000s to supply fuel to the second phase of the Dabhol power plant project. ${ }^{135}$ The project was shut down until July 2005, at which time it was taken over by Ratnagiri Gas and Power Private Ltd. ${ }^{136}$ The firstphase power plant restarted operations in May 2006, after a hiatus of over five years, but was shut down two months later due to a lack of naphtha. ${ }^{137}$ The Dabhol import terminal (rechristened Ratnagiri) received its first cargo in January 2013. ${ }^{138}$ Ratnagiri now supplies the largest gas-fired power plant in the country $(1,967 \mathrm{MW})$ with LNG imported from Nigeria. ${ }^{139}$

\footnotetext{
132 EIA website, "India," http://www.eia.gov/countries/country-data.cfm?fips=IN

133 ibid.

134 ibid.

${ }^{135}$ U.S. House of Representatives, Committee on Government Reform, "Fact Sheet: Background on Enron's Dabhol Power Project," February 22, 2002, http://finance-mba.com/Dabhol_fact_sheet.pdf.

${ }^{136}$ Ratnagiri Gas and Power Pvt. Ltd. website, "Welcome to Ratnagiri Gas and Power Private Limited," http://www.rgppl.com/.

${ }^{137}$ LNG Journal, "Indian LNG import terminal caught up in Enron collapse heads for February start-up," October 29, 2012.

${ }^{138}$ LNG World News, "Gazprom Delivers Commissioning Cargo to Dabhol LNG Terminal in India," January 21, 2013, http://www.lngworldnews.com/gazprom-delivers-commissioning-cargo-to-dabhol-lng-terminal-in-india/.

${ }^{139}$ LNG Journal, "Indian LNG."
} 
Petronet LNG Ltd. (Petronet) was the first to successfully import LNG into India, and is the largest importer of LNG in the country. ${ }^{140}$ India's government formed Petronet to construct and operate LNG terminals and import LNG. Four state-controlled companies each own 12.5 per cent of Petronet: GAIL; Oil and Natural Gas Corporation Ltd. (ONGC); Indian Oil Corporation Ltd. (IOCL); and Bharat Petroleum Corporation Ltd. (BPCL). ${ }^{141}$ GDF SUEZ, a strategic partner, owns 10 per cent equity in Petronet, the Asian Development Bank holds 5.2 per cent, and the balance is publicly traded. Petronet commenced commercial operations at its Dahej terminal in April 2004. Petronet supplies Dahej through a long-term contract with Qatar's RasGas for 7.5 MMTPA, and supplies the new Kochi terminal with a contract for 1.44 MMTPA with the Gorgon project in Australia. ${ }^{142}$

The Hazira import terminal, owned by Shell (74 per cent) and Total ( 26 per cent), was commissioned in April 2005 and started commercial operations in 2006. ${ }^{143}$ The Hazira LNG terminal was the first to introduce spot LNG supplies into India. ${ }^{144}$ India has a total of three receiving terminals with a combined import capacity of 25 MMTPA. ${ }^{.45}$ Under-construction and planned or proposed new terminals will add 19.5 MMTPA of capacity, if all are completed.

\section{FIGURE A2.6: INDIA'S LNG IMPORT TERMINAL CAPACITY BY OPERATOR}

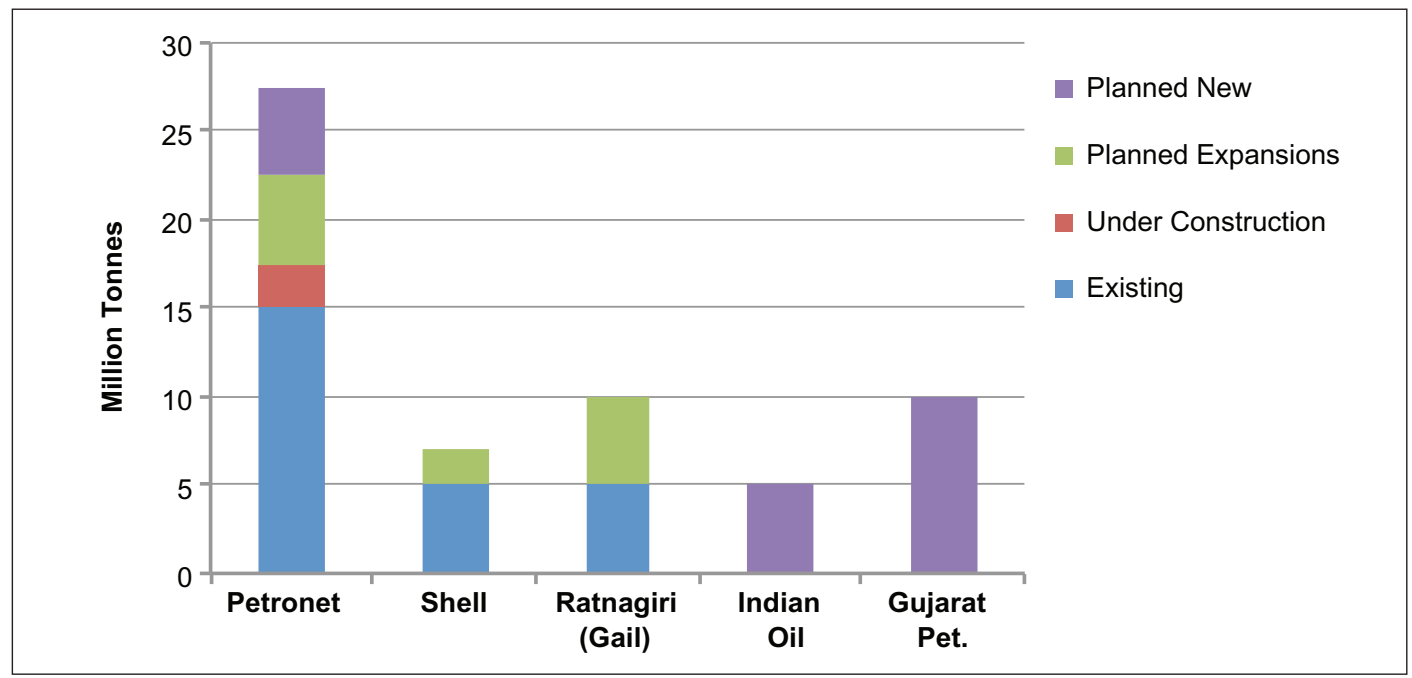

Source: GIIGNL, The LNG Industry in 2013 (Paris: GIIGNL, 2013), http://www.giignl.org/publications/Ing-industry-2013 and Appendix F.

\footnotetext{
${ }^{140}$ Petronet LNG Ltd. website, “Dahej LNG Terminal,” http://www.petronetlng.com/Dahej_LNG_Terminal.aspx.

${ }^{141}$ Petronet LNG Ltd. website, “Corporate Presentation,” May 20, 2014, http://www.petronetlng.com/PDF/USDCorporate\%20Presentation-May-2014-20.pdf.

${ }^{142}$ Petronet LNG Ltd. website, "LNG Sources,” http://www.petronetlng.com/lng-source.aspx.

${ }^{143}$ Hazira LNG and Port website, "Company History," http://www.haziralngandport.com/company_history.htm.

${ }^{144}$ Hazira LNG and Port website, "Additional Information on Hazira," http://www.haziralngandport.com/brief_write_up.htm.

${ }^{145}$ See Appendix F for sources.
} 
India's primary energy consumption in 2012 was only about one-fifth of China's. ${ }^{146}$ On a percapita basis, in 2011 India's energy use was 30 per cent of China's and 45 per cent of Brazil's. ${ }^{147}$ Growth in natural gas demand will come from a combination of rising energy consumption and an increase in the share of natural gas in India's fuel mix. The natural gas supply scenario in India has improved due to increased domestic gas production and the importation of LNG. However, a lack of pipeline infrastructure throughout India has limited its ability to use domestic supplies to meet domestic demand. ${ }^{148}$

FIGURE A2.7: INDIA'S NATURAL GAS PRODUCTION AND CONSUMPTION (1971 - 2012)

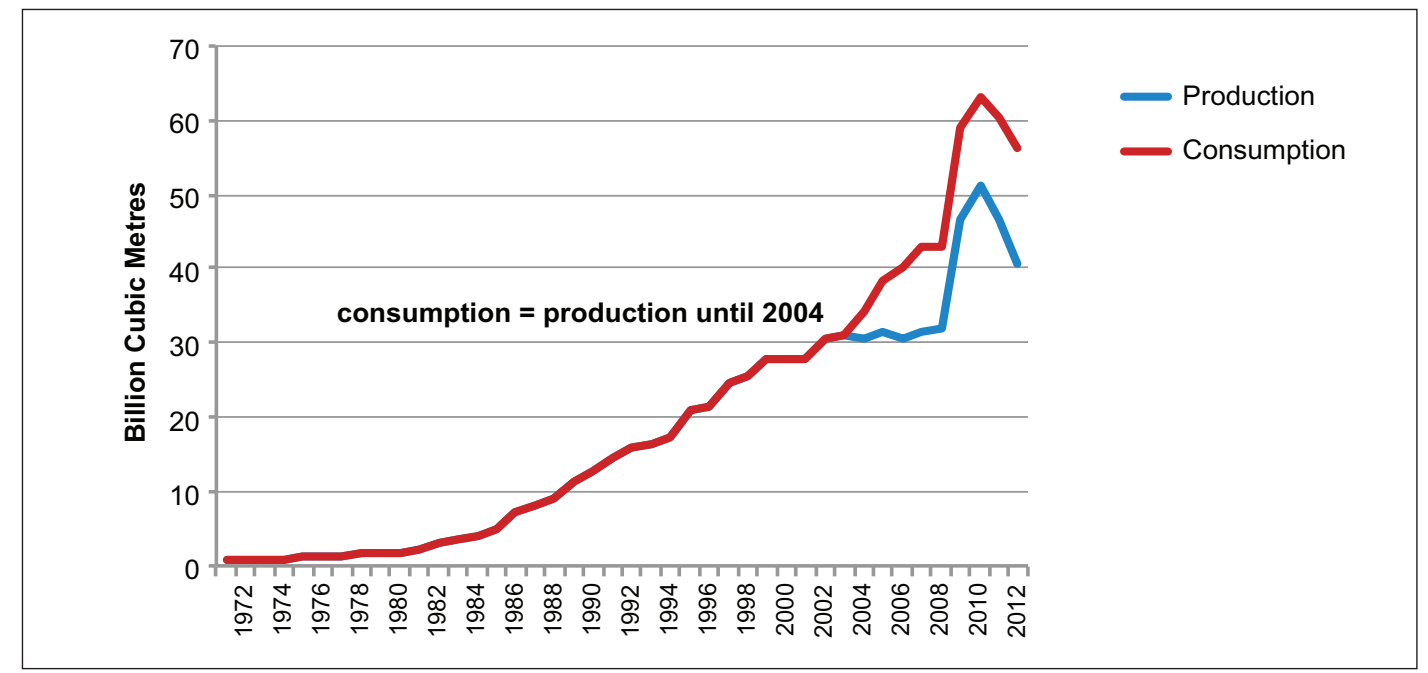

Source: IEA, "World - Natural Gas statistics," IEA Natural Gas Information Statistics (database), 2013, doi: 10.1787/data-00482-en.

In 2012 India produced 40.4 BCM of natural gas, compared to its consumption of $56.3 \mathrm{BCM}$ (Figure A2.7). The gap between consumption and domestic production was met through importing 12.4 MMT of LNG from six countries, of which 80 per cent came from Qatar (Figure A2.8).

\footnotetext{
${ }^{146}$ BP, BP Statistical Review (2013).

${ }^{147}$ World Bank, "Energy use (kg of oil equivalent per capita)," http://data.worldbank.org/indicator/EG.USE.PCAP.KG.OE.

${ }^{148}$ EIA website, "India."
} 
FIGURE A2.8: INDIA'S LNG IMPORTS BY SUPPLY COUNTRY (2010 - 2012)

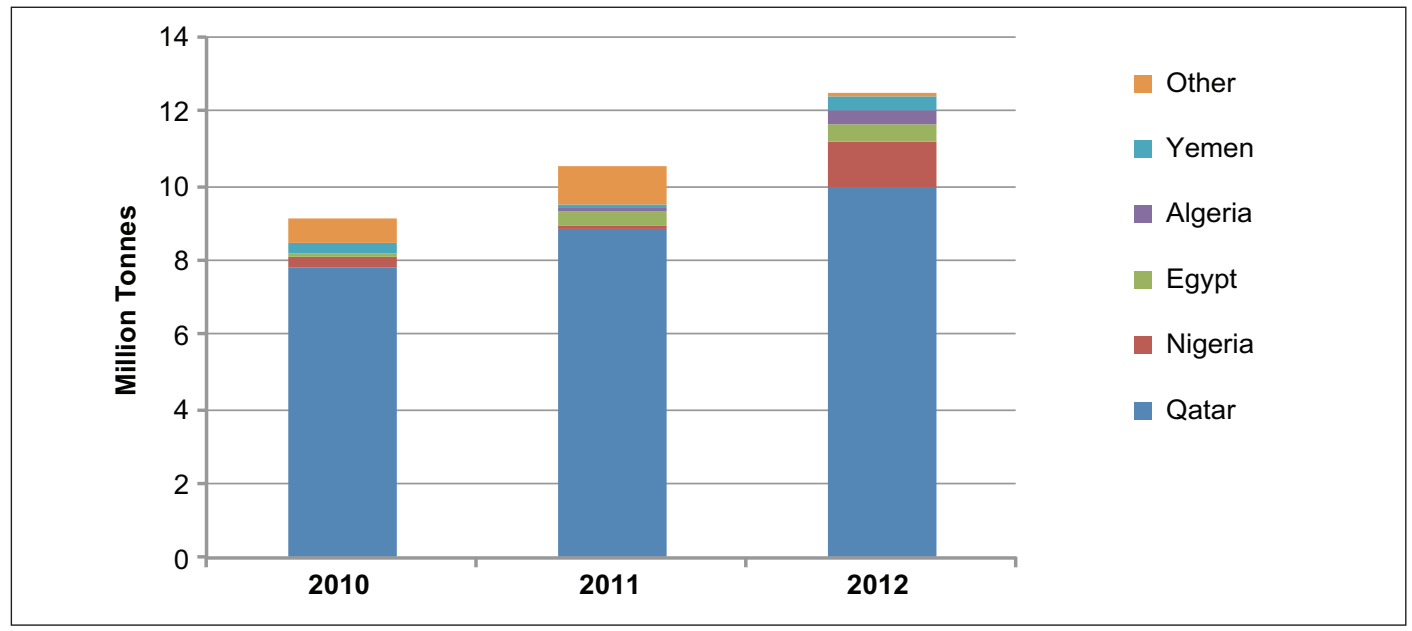

Note: "Other" includes Australia, Equatorial Guinea, Malaysia, Norway, Oman, Trinidad and Tobago, the United Arab Emirates, the United States and "non-specified/other."

Source: IEA, “World - Natural Gas imports by origin,” IEA Natural Gas Information Statistics (database), 2013, doi: 10.1787/data-00555-en.

India had 1.241 TCM of proved natural gas reserves at the start of 2013, representing a reserves/production ratio of 30 years. ${ }^{149}$ About 30 per cent of these reserves are onshore, while 70 per cent are offshore. ${ }^{150}$ India's upstream gas (and oil) sectors are dominated by ONGC and Oil India Ltd. ${ }^{151}$ ONGC provides a large amount of India's natural gas supply through its operation of the offshore Mumbai High Field. ${ }^{152}$ The government has encouraged private Indian companies and foreign companies to enter the upstream sector, and Reliance Industries, in partnership with BP, has been successful in entering, though there is limited activity from other major international oil companies. ${ }^{153}$

In 2002, a number of large gas discoveries were made in the Krishna-Godavari basin off of India's eastern coast. ${ }^{154}$ Much of India's recent increase in gas production came from the D6 fields in this basin. The D6 fields came online in early 2009, producing about $85 \mathrm{MMCM}$ per day in March 2009, which increased to almost $169 \mathrm{MMCM} / \mathrm{d}$ a year later. ${ }^{155}$ However, production fell to about 28.3 MCM/d in mid-2012, contributing to a two-year decline in India's domestic gas production. The operator cut the reserves of the major D6 field from 491.5 BCM in 2006 to $96.2 \mathrm{BCM}$ in 2012, because of the declines, and is considering shutting down the field. ${ }^{156}$ Not only would this have a significant impact on India's gas production, but it also raises concerns about the reliability of India's domestic gas supplies. Other potential fields are currently being explored and developed, but little is known about potential (or proven) reserves.

\footnotetext{
${ }^{149}$ CIA World Factbook, "India," https://www.cia.gov/library/publications/the-world-factbook/geos/in.html.

${ }^{150}$ EIA website, "India."

151 ibid.

152 ibid.

153 ibid.

154 ibid.

155 ibid.

${ }^{156}$ ibid.
} 
Despite prospects for increasing domestic natural gas production, PFC Energy expects that India will become one of the largest LNG markets. ${ }^{157} \mathrm{PFC}$ suggests imports could be at 30 MMTPA (40.8 BCM) by 2020, and the gap between supply and demand for natural gas is projected to grow to the equivalent of $55.7 \mathrm{BCM}$ (41 MMTPA) by $2030 .{ }^{158}$ The IEA predicts India's demand for natural gas will be $87 \mathrm{BCM}$ in 2020, and reach $140 \mathrm{BCM}$ by $2030 .{ }^{159}$ The EIA's prediction is more conservative, with natural gas demand reaching 76.4 BCM in 2020 and $96.2 \mathrm{BCM}$ in $2030 .{ }^{160}$ With a four per cent per year growth in natural gas demand, Figure A2.9 shows that production and contracted volumes are sufficient to supply demand up to 2025. The gap between supply and demand reaches 12 BCM in 2030 as existing LNG supply contracts expire. If India's demand growth slows, the gap will be less severe; however, if gas production falls, then the gap could open up as early as 2020 .

FIGURE A2.9: INDIA'S NATURAL GAS SUPPLY-DEMAND BALANCE

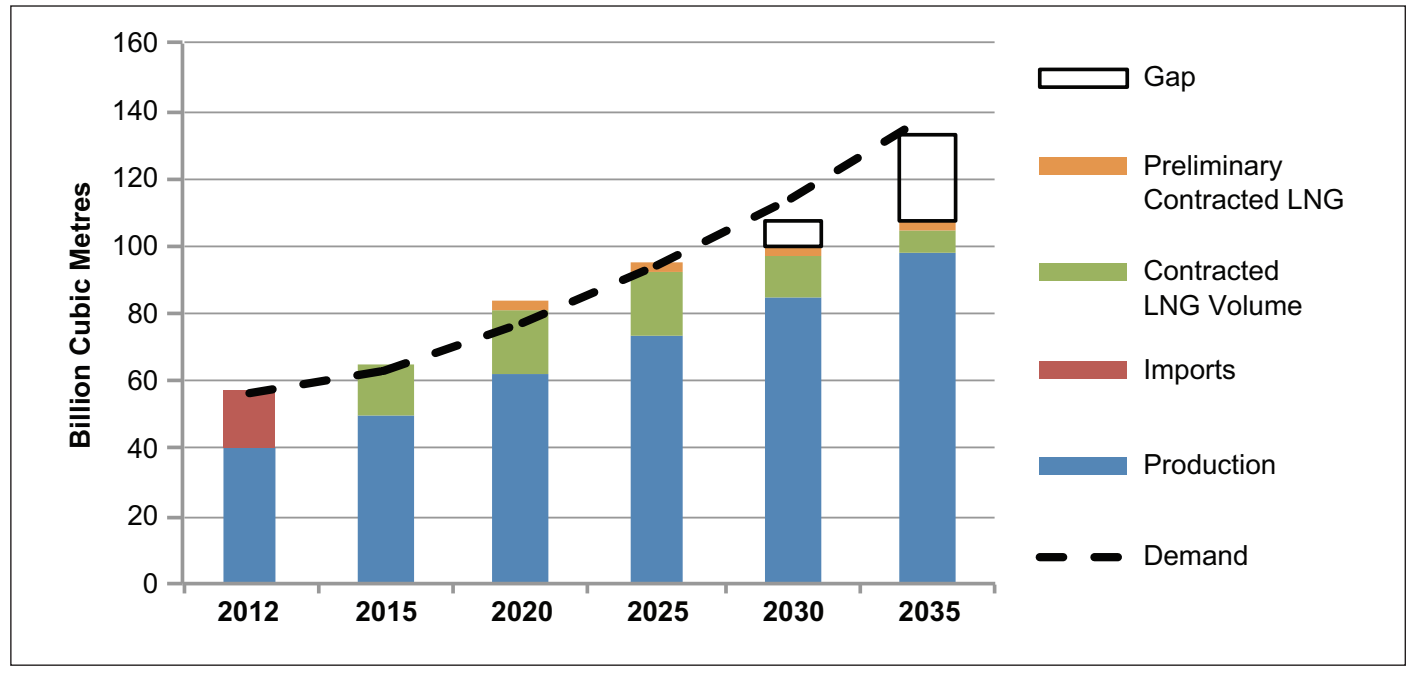

Notes: Production, imports, exports and consumption (demand) data for 2012 from IEA, “World - Natural Gas statistics," IEA Natural Gas Information Statistics (database), 2013, doi: 10.1787/data-00482-en. An annual growth rate of four per cent for natural gas demand was used. Production forecast from IEA, World Energy Outlook (Paris: OECD/IEA, 2013). LNG contracted volume from Bloomberg LNG Contract Database. Contracts defined as preliminary are with projects where no final investment decision has been made for the supplier.

Like their counterparts in China, Indian companies have been pursuing international upstream and LNG ventures to secure natural resources for the home market. ONGC and Oil India Ltd. have equity interests in the Mozambique LNG project. ${ }^{161}$ GAIL has secured LNG under longterm agreements from Cheniere's Sabine Pass (3.5 MMTPA) and Dominion Cove Point (2.3 MMTPA) in the U.S., as well as from Gazprom's Shtokman LNG project (2.5 MMTPA). ${ }^{162}$ Supplies from these projects are expected to commence between 2018 and 2020.

\footnotetext{
${ }^{157}$ PFC Energy, Global LNG.

158 ibid.

${ }^{159}$ IEA, World Energy Outlook.

${ }^{160}$ EIA, International Energy Outlook 2013 (Washington, D.C.: U.S. Department of Energy, 2013).

161 Oil and Natural Gas Corporation Ltd., "Mozambique Minister for Mineral Resources promises early LNG deals with Indian companies," news release, January 15, 2014, http://www.ongcindia.com/wps/wcm/connect/ongcindia/home/press_release/mozambique-minister-lngdealsindiancompanies.

${ }^{162}$ GAIL (India) Ltd. website, “LNG,” http://www.gail.nic.in/final_site/lng.html.
} 
A3 Emerging LNG Buyers of Southeast Asia: Indonesia, Malaysia, the Philippines, Singapore, Thailand, and Vietnam

\section{A3.1 CHARACTERISTICS OF EMERGING LNG BUYERS OF SOUTHEAST ASIA}

The emerging LNG buyers of Southeast Asia have just started importing LNG, or are poised to become LNG buyers in the next decade. A characteristic that Thailand, Singapore, Malaysia, Indonesia, the Philippines and Vietnam share is that they have established natural gas markets and infrastructure based on pipeline gas supplies, but will be forced to import LNG to supplement or replace pipeline gas supplies as these pipeline gas resources are depleted. As a group, these six countries consume a substantial quantity of natural gas in their domestic markets while, at the same time, they are significant exporters of natural gas through pipelines and as LNG. Collectively, they consumed 141.5 BCM of natural gas in 2012, ranging from 51.2 BCM in Thailand to 3.4 BCM in the Philippines. ${ }^{163}$

Figure A3.1 shows natural gas supply and demand by country in 2012. The Philippines and Vietnam rely solely on domestic production to supply their consumption. Thailand supplements domestic production with pipeline and LNG imports. Singapore supplies demand with pipeline imports alone. Malaysia and Indonesia are both net exporters, though Malaysia supplements domestic production with pipeline imports.

FIGURE A3.1: SOUTHEAST ASIA'S NATURAL GAS SUPPLY IN 2012

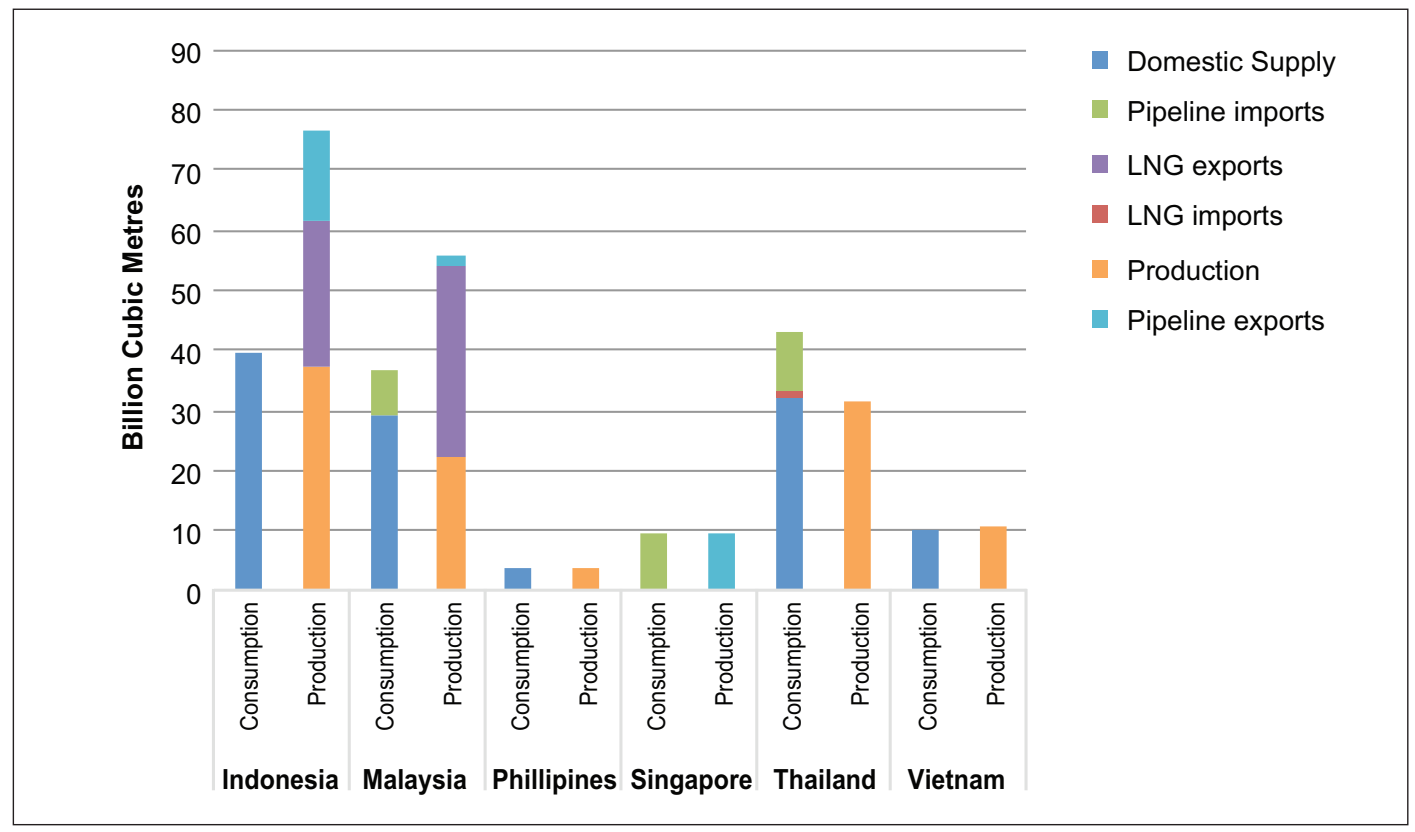

Source: IEA, "World - Natural Gas imports by origin," IEA Natural Gas Information Statistics (database), 2013, doi: 10.1787/data-00555-en; and IEA, "World - Natural Gas statistics," IEA Natural Gas Information Statistics (database), 2013, doi: 10.1787/data-00482-en.

\footnotetext{
${ }^{163}$ BP, BP Statistical Review (2013).
} 
Southeast Asia is experiencing rapid economic growth, with demand for energy growing at commensurate rates. Coal and liquid fuels are consumed throughout the region, although concerns about air quality are driving the region toward increased natural gas consumption. With growth in demand for natural gas, and an increasing role for LNG imports in meeting the demand, Southeast Asia will emerge as a significant market for LNG in the next several decades.

In Southeast Asia, pipeline gas supplies are much less expensive than LNG and, with the exception of Singapore, pipeline gas is the preferred option for meeting natural gas demand, particularly when pipeline gas is sourced from domestic resources. The inherent uncertainty of future pipeline gas supplies and resistance to LNG prices, which are much higher than historic pipeline gas prices, makes it difficult for Southeast Asian LNG buyers to commit to long-term commitments for substantial LNG imports, with Singapore being the notable exception. Singapore, a less price-sensitive market, has started importing LNG to supplement and replace its pipeline gas supplies, to provide energy security, and to help establish Singapore as a regional natural gas trading hub.

\section{A3.4 INDONESIA}

Indonesia is an archipelago of 17,500 islands, of which 6,000 are inhabited. ${ }^{164}$ It is the most populous country in Southeast Asia and the fourth most populous country in the world (behind China, India, and the United States) ${ }^{165}$ The island of Java is the centre of government, business and industry, and home to the majority of Indonesia's 253 million people.

Indonesia's oil and gas resources are spread from Aceh province at the western extreme of Indonesia to Papua province at the eastern end of the archipelago. ${ }^{166}$ Indonesia has three LNG export plants: Arun LNG in Aceh province on the island of Sumatra; Bontang LNG in East Kalimantan on the island of Borneo; and Tangguh LNG in Papua province on the island of New Guinea. A small, 2-MMTPA export plant is under construction on the island of Sulawesi, with expected start up in $2014 .{ }^{167}$

Indonesia is self-sufficient in natural gas resources (Figure A3.2). Natural gas production offshore Java and onshore Sumatra serves most of the domestic market, while most of the natural gas produced in the rest of the country is exported as LNG or consumed by industries co-located with the liquefaction plants (e.g., fertilizer). In 2012, Indonesia produced 76.7 BCM of natural gas, consumed 39.3 BCM, exported 24.2 BCM as LNG, and exported 15.1 BCM through pipelines to Singapore and Malaysia. ${ }^{168}$

\footnotetext{
${ }^{164}$ CIA World Factbook, "Indonesia," https://www.cia.gov/library/publications/the-world-factbook/geos/id.html.

165 CIA World Factbook, "Country Comparison: Population," https://www.cia.gov/library/publications/the-worldfactbook/rankorder/2119rank.html.

${ }^{166}$ EIA website, “Indonesia," http://www.eia.gov/countries/cab.cfm?fips=ID.

${ }^{167}$ Mitsubishi Corp., "Final Investment Decision on Donggi-Senoro LNG Project in Indonesia," news release, January 24, 2011, http://www.mitsubishicorp.com/jp/en/pr/archive/2011/html/0000011637.html.

${ }^{168}$ IEA, "World - Natural Gas imports; and IEA, "World - Natural gas statistics."
} 
Indonesia had proved natural gas reserves of $3.069 \mathrm{TCM}$ at the start of $2013,{ }^{169}$ which translates to a reserves-to-production ratio of 40 years based on 2012 production reported by the IEA. Indonesia's reserves have been steady or slightly increasing for the last 10 years. ${ }^{170}$ Indonesia's natural gas production has risen steadily in the past decade, keeping pace with the growth in domestic consumption and slowly declining LNG exports. While production is declining in more mature producing fields, new deep-water developments have the potential to offset this decline. ${ }^{171}$ The IEA forecasts that Indonesia's production will continue to increase, reaching $108 \mathrm{BCM}$ in 2020 and $129 \mathrm{BCM}$ in $2030 .^{172}$

FIGURE A3.2: INDONESIA'S NATURAL GAS PRODUCTION AND CONSUMPTION (1971 - 2012)

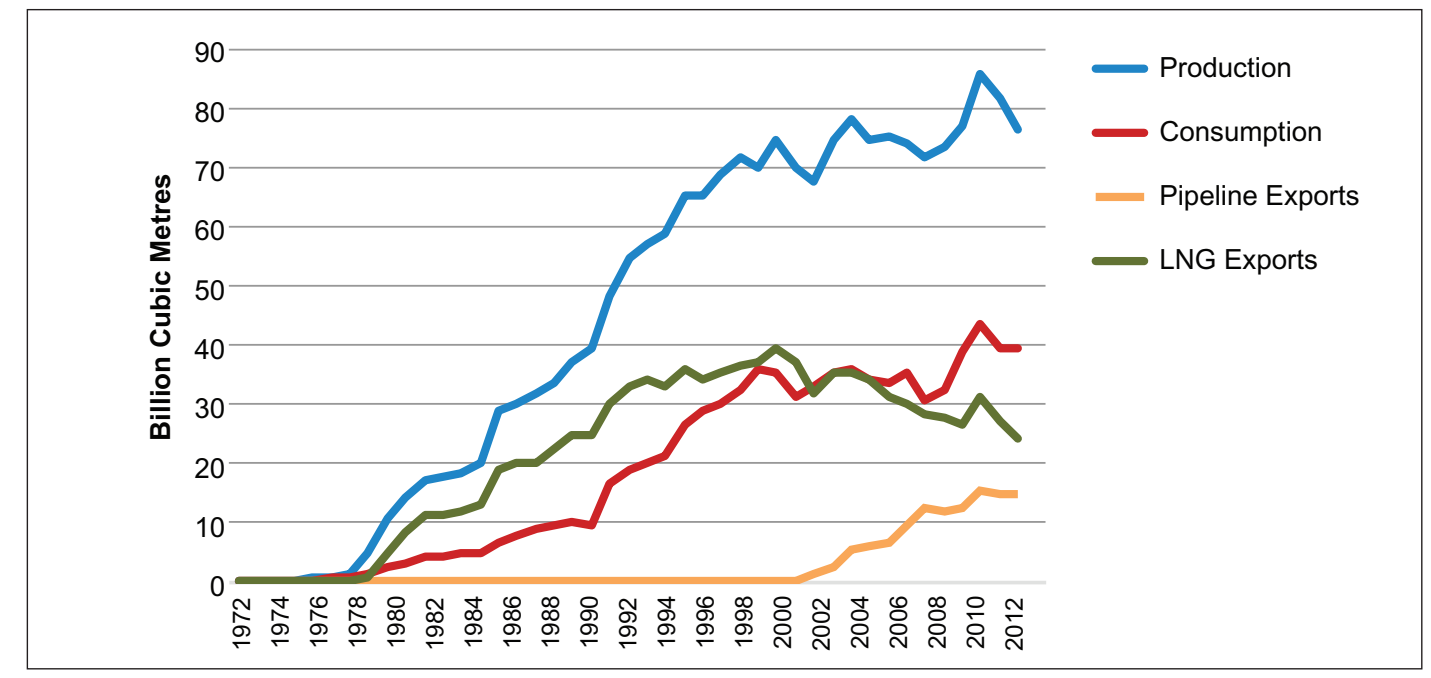

IEA, “World - Natural Gas statistics," IEA Natural Gas Information Statistics (database), 2013, doi: 10.1787/data-00482-en.

However, there is a growing mismatch between the geographic distribution of the country's gas reserves and the resources available to serve the largest domestic markets in Java and Sumatra. As a consequence, Indonesia has been preparing for LNG imports into Java and Sumatra to meet domestic natural gas demand. ${ }^{173}$ However, domestic distribution infrastructure is almost non-existent outside of Java and North Sumatra. ${ }^{174}$

Indonesia has been an LNG exporter for four decades. However, increasing domestic demand for natural gas, combined with a decline in natural gas production feeding its liquefaction plants at Arun and Bontang, have led to speculation that Indonesia might become an importer of LNG before the end of the decade. ${ }^{175}$

\footnotetext{
${ }^{169}$ CIA World Factbook, "Indonesia."

${ }^{170}$ BP, BP Statistical Review (2013).

${ }^{171}$ EIA website, "Indonesia."

172 IEA, World Energy Outlook 2013.

${ }^{173}$ EIA website, "Indonesia."

174 ibid.

175 ibid.
} 
Arun LNG has been gradually mothballing trains since 2000 as the gas feed to the plant declined. The website for Arun LNG notes that new gas fields will ensure sufficient gas supply to meet contractual LNG demand until $2015 .^{176}$ The Arun facility will likely be converted into an import terminal. ${ }^{177}$ The Bontang plant (19.6 MMTPA), of the same vintage as Arun, will eventually share the same fate, or have a significant portion of its LNG output diverted to domestic markets as contracts, primarily with North Asian buyers, expire.

A floating import terminal was commissioned offshore West Java, Indonesia in mid-2012. ${ }^{178}$ Indonesia can import LNG, or can ship LNG from its export plants in East Kalimantan and Papua provinces to West Java. In 2012, 0.7 MMT of LNG was delivered from Bontang to West Java. ${ }^{179}$ Indonesia has signed its first import contract with Cheniere Energy in the United States, with delivery starting in $2018 .{ }^{180}$

Neither the EIA nor the IEA have official forecasts for natural gas demand growth in Indonesia. PFC Energy forecasts that Indonesian demand will reach approximately 54 BCM by 2020 and over 68 BCM by 2030, but will remain self-sufficient in natural gas for the foreseeable future, with a supply-demand gap possibly opening up by $2035 .{ }^{181}$ Based on IEA production forecasts, a demand growth rate of six per cent per year is required for demand to surpass domestic production by 2035 . However, it is likely that Indonesia's LNG exports will continue to decline as Indonesia's natural gas production is diverted to domestic markets.

FIGURE A3.3: INDONESIA'S NATURAL GAS SUPPLY-DEMAND BALANCE

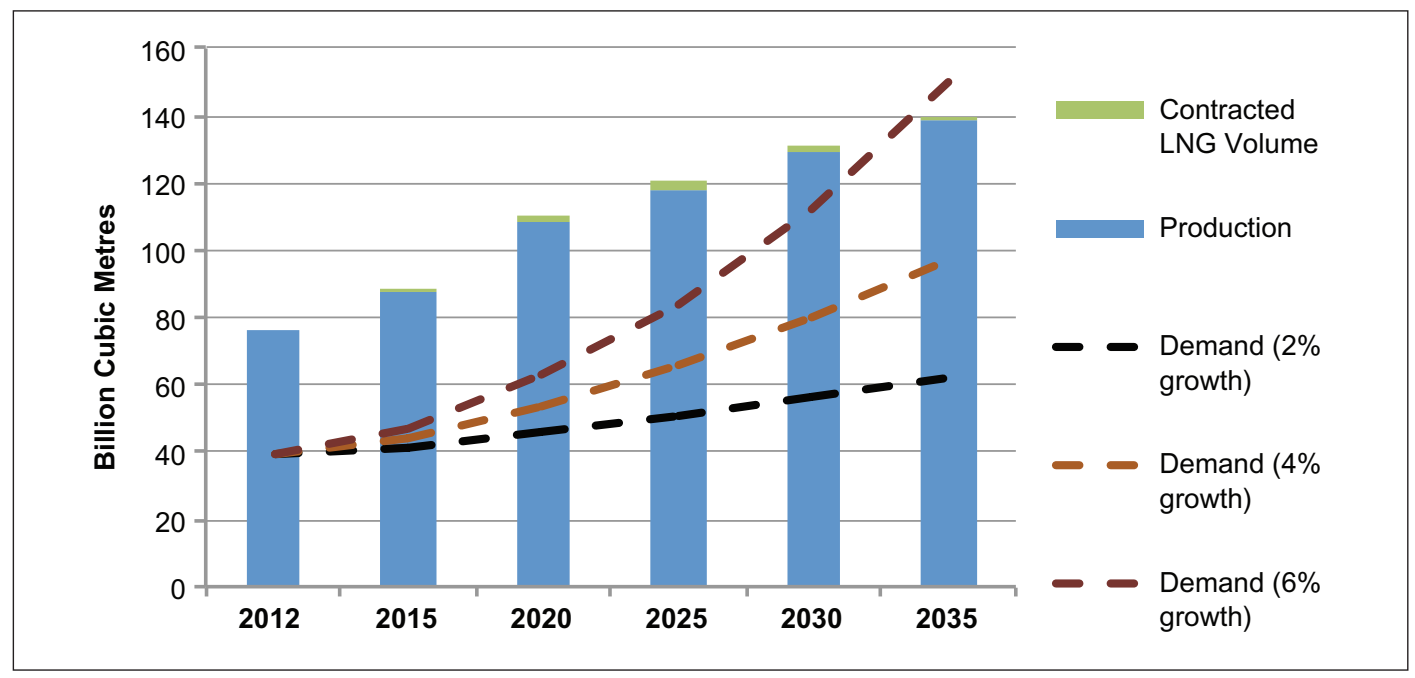

Notes: Production, imports and consumption (demand) data for 2012 from IEA, "World - Natural Gas statistics," IEA Natural Gas Information Statistics (database), 2013, doi: 10.1787/data-00482-en. Production forecast from IEA, World Energy Outlook (Paris: OECD/IEA, 2013). Contract volumes from Bloomberg POTN (Poten \& Partners) LNG contract database.

\footnotetext{
${ }^{176}$ PT Arun NGL website, “Our Profile,” http://www.arunlng.co.id/profile.php.

${ }^{177}$ Pertamina, "Repositioning Arun LNG Plant - 1st Time in LNG History, From Liquefaction Become Ragasification Terminal," presentation by Daniel Purba at LNG 17 conference, April 16, 2013, http://www.gastechnology.org/Training/Documents/LNG17-proceedings/03_05-Daniel-Purba-Presentation.pdf.

${ }^{178}$ GIIGNL, The LNG Industry in 2013.

${ }^{179}$ GIIGNL, The LNG Industry in 2012.

${ }^{180}$ EIA website, "Indonesia."

${ }^{181}$ PFC Energy, Global LNG.
} 


\section{A3.3 MALAYSIA}

Malaysia consists of two distinct geographic regions: Western, or Peninsular, Malaysia, where the majority of approximately 28 million Malaysians live, and the states of Sabah and Sarawak on the island of Borneo in Eastern Malaysia. ${ }^{182}$ Natural gas production offshore Peninsular Malaysia serves the domestic market, while most of the natural gas produced in Eastern Malaysia is exported as LNG. ${ }^{183}$

In 2012, Malaysia produced 55.6 BCM of natural gas, consumed 36.8 BCM, and exported 31.5 BCM as LNG. Malaysia is self-sufficient in natural gas resources. However, Malaysia imported 7.4 BCM in 2012 into Peninsular Malaysia via pipeline from fields in Indonesian territorial waters. ${ }^{184}$ Malaysia exports a similar quantity of gas from Peninsular Malaysia to Singapore under two pipeline contracts, each for 118 BCM, that expire in 2017 and 2022, respectively. ${ }^{185}$

Malaysia had proved natural gas reserves of 2.35 TCM, with a reserves-to-production ratio of 42 years based on the IEA's reported 2012 production. ${ }^{186}$ Malaysia's reserves have been in general decline since 2007, after plateauing at about 2.5 TCM for the 10-year period from 1997 to $2006 .{ }^{187}$ Recent discoveries offshore Sarawak and Sabah are expected to reverse the decline in reserves. ${ }^{188}$ Malaysia's natural gas production has risen steadily in the past decade, keeping pace with the growth in domestic consumption and increased LNG exports (Figure A3.4).

\footnotetext{
${ }^{182}$ Department of Statistics Malaysia, "Population Distribution and Basic Demographic Characteristics,” 2010, http://www.statistics.gov.my/portal/download_Population/files/census2010/Taburan_Penduduk_dan_Ciriciri_Asas_Demografi.pdf.

${ }^{183}$ EIA website, "Malaysia," http://www.eia.gov/countries/cab.cfm?fips=MY.

${ }^{184}$ IEA, "World - Natural Gas imports."

${ }^{185}$ EIA website, "Singapore," http://www.eia.gov/countries/cab.cfm?fips=SN.

${ }^{186}$ CIA World Factbook, "Malaysia," https://www.cia.gov/library/publications/the-world-factbook/geos/my.html.

${ }^{187}$ BP, BP Statistical Review (2013).

${ }^{188}$ Florence Tan, “Malaysia's \$30 bln drive reverses oil decline, boosts gas,” Reuters, June 14, 2013, http://www.reuters.com/article/2013/06/14/malaysia-oil-idUSL3NOEM2UQ20130614.
} 


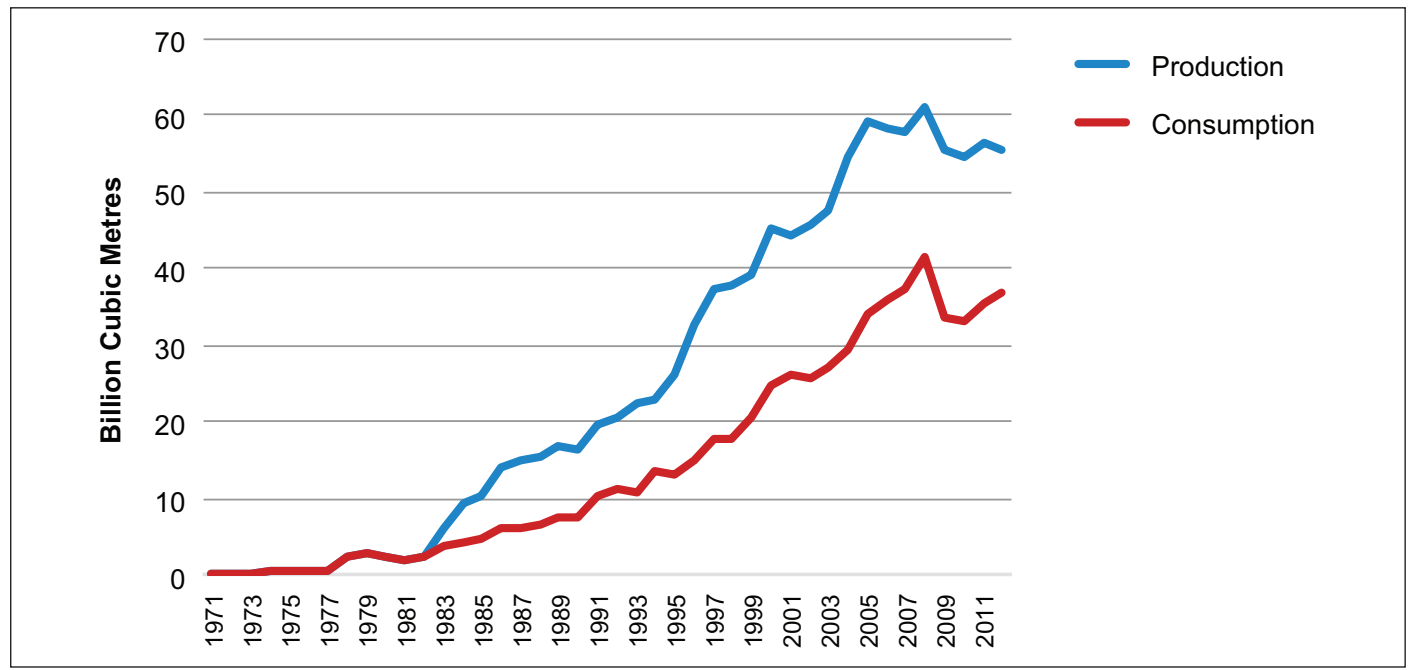

Source: IEA, “World - Natural Gas statistics,” IEA Natural Gas Information Statistics (database), 2013, doi: 10.1787/data-00482-en.

Malaysia's gas production is about equally split between the domestic market and LNG exports, though the share for domestic use has been above sixty per cent since $2006 .{ }^{189}$ However, there is a growing mismatch between the geographic distribution of the country's gas resources, which are concentrated in Eastern Malaysia, and the resources available to serve the domestic market in Peninsular Malaysia. The power sector accounts for about 74 per cent of natural gas demand, and demand for power, especially in Peninsular Malaysia, is expected to continuing growing. ${ }^{190}$ Gas production offshore Peninsular Malaysia is expected to decline after 2015, creating a supply-demand gap in the domestic market. ${ }^{191}$ As a consequence, Malaysia has been preparing for LNG imports into Peninsular Malaysia to meet domestic natural gas demand. ${ }^{192}$

Malaysia's first LNG import terminal, a floating storage and regasification unit, with a capacity of 3.8 MMTPA, became operational in $2013 .{ }^{193}$ Petronas has access to LNG from several LNG export projects in which it participates in Malaysia, Egypt and Australia. ${ }^{194}$

PFC Energy predicts that by 2020 there will be a growing natural gas supply-demand gap in Peninsular Malaysia, and that the gap is expected to grow to the equivalent of 8 MMTPA in 2025 and 11 MMTPA by $2030 .{ }^{195}$ Figure A3.5 shows two scenarios for Malaysia, both with two per cent per year increases in natural gas demand. In Panel A, expiry of export contracts for pipeline gas and LNG increase the availability of domestically produced gas for domestic consumption. Only the elimination of all imported pipeline gas would create a gap between supply and demand. In Panel B, the assumption is that the availability of domestically produced gas stays constant at 2012 volumes, as do pipeline imports. In this case, a gap opens up between contracted volumes and demand in 2020.

\footnotetext{
${ }^{189}$ IEA, "World - Natural Gas statistics."

${ }^{190}$ EIA website, "Malaysia."

${ }^{191}$ PFC Energy, Global LNG.

192 EIA website, "Malaysia."

193 GIIGNL, The LNG Industry in 2013.

${ }^{194}$ Petronas website, "LNG," http://www.petronas.com.my/our-business/gas-power/lng/Pages/default.aspx.

${ }^{195}$ PFC Energy, Global LNG.
} 
PANEL A

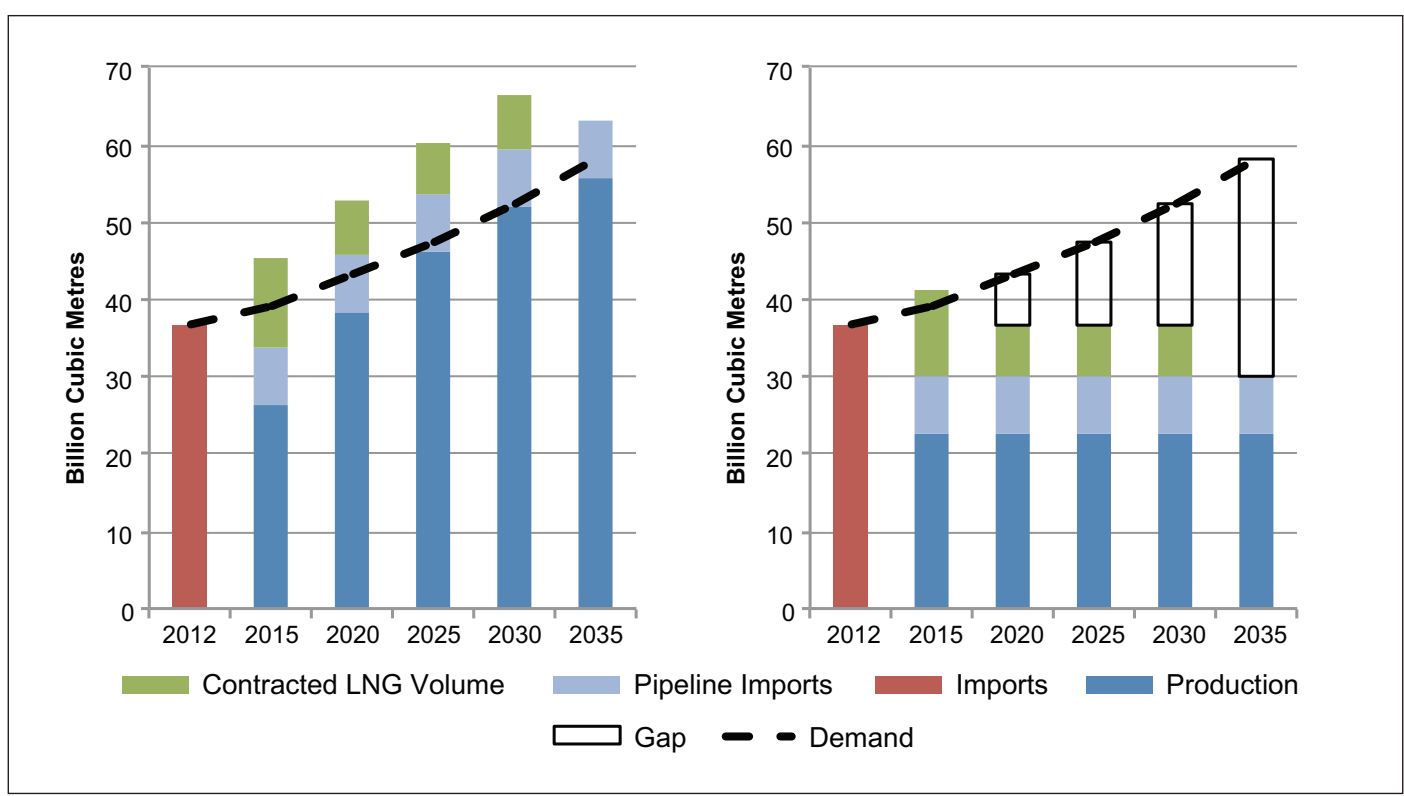

Notes: Production, imports, exports and consumption (demand) data for 2012 from IEA, “World - Natural Gas statistics," IEA Natural Gas Information Statistics (database), 2013, doi: 10.1787/data-00482-en. An annual growth rate of two per cent for natural gas demand was used. Production is assumed to continue at 2012 levels. Pipeline imports are assumed to continue at 2012 volumes. LNG contracted volume from Bloomberg LNG Contract Database. Panel A shows the supply-demand balance when domestically available production increases due to expiry of pipeline and LNG export contracts. Panel B shows the supply-demand balance assuming that pipeline and LNG exports stay at 2012 levels, decreasing production available for domestic use.

\section{A3.6 REPUBLIC OF THE PHILIPPINES}

The Philippines is an archipelago of 7,107 islands. ${ }^{196}$ The island of Luzon is the most populous and is the centre of government. The Philippines is the 12th most populous country in the world, and the second most populous in Southeast Asia, ${ }^{197}$ with a per capita GDP of $\$ 4,700.198$

The country's sole source of natural gas is the offshore Malampaya field, ${ }^{199}$ which produces about 3.8 BCM of natural gas per year. ${ }^{200}$ Production from the field started in 2001. The field is owned by Shell, Chevron, and the Philippines National Oil Corporation (PNOC) ${ }^{201}$ Gas is transported from Malampaya to Southern Luzon through a 505-kilometre subsea pipeline. ${ }^{202}$

\footnotetext{
${ }^{196}$ CIA World Factbook, "Philippines," https://www.cia.gov/library/publications/the-world-factbook/geos/rp.html.

197 CIA World Factbook, "Country Comparison: Population."

198 CIA World Factbook, "Philippines."

${ }^{199}$ Republic of the Philippines Department of Energy website, "Natural Gas," https://www.doe.gov.ph/fossilfuels/natural-gas.

${ }^{200}$ IEA, "World - Natural gas statistics."

${ }^{201}$ Shell website, "Malampaya," http://www.shell.com/global/aboutshell/major-projects-2/malampaya.html.

${ }^{202}$ Chevron website, "Philippines Business Portfolio," http://www.chevron.com/countries/philippines/businessportfolio/.
} 
Gas from Malampaya supplies three combined-cycle, gas-fired power plants with a combined generating capacity of $2,700 \mathrm{MW} \cdot{ }^{203}$ The three plants were constructed to monetize the Malampaya discovery, ${ }^{204}$ and provide 40 to 45 per cent of Luzon's power generation requirements. ${ }^{205}$ Prior to the development of the Malampaya field, small amounts of gas were produced from the Cagayan Valley in Northern Luzon. ${ }^{206}$

FIGURE A3.6: PHILIPPINES' NATURAL GAS CONSUMPTION (1990 - 2012)

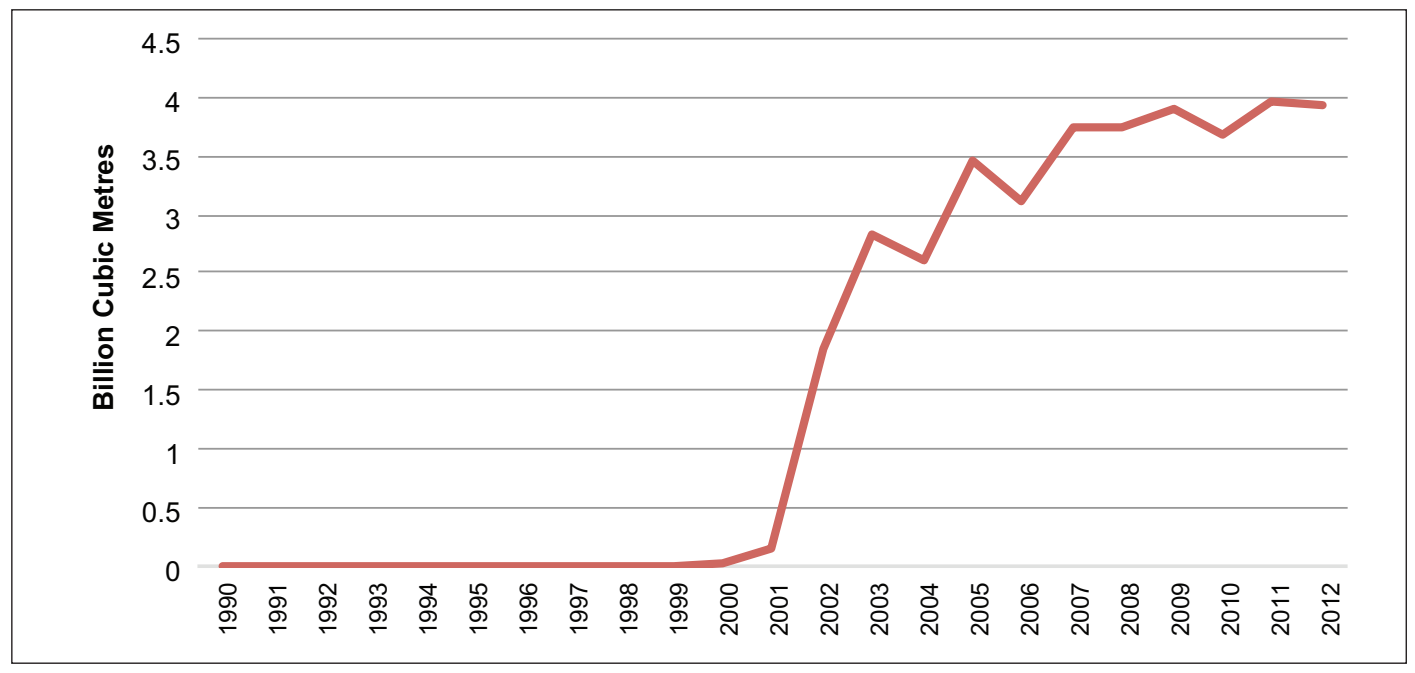

Source: IEA, "World - Natural Gas statistics," IEA Natural Gas Information Statistics (database), 2013, doi: 10.1787/data-00482-en.

Exploration has thus far been unsuccessful in extending the Philippines' commercial-gas resource base beyond the Malampaya area. ${ }^{207}$ The government is attempting to expand the use of natural gas in the power, industrial and transport sectors, ${ }^{208}$ but due to a lack of domestic gas resources, and no current infrastructure for LNG imports, attempts to expand gas penetration have failed.

PFC Energy estimates that Malampaya's gas production, and gas supply to the Luzon power plants, will be maintained at current levels through 2020, and additional gas resources will be required to maintain this level of output beyond $2020 .{ }^{209}$ The initial reserve estimate for the Malampaya field was $76.4 \mathrm{BCM},{ }^{210}$ of which $36.5 \mathrm{BCM}$ has been produced. ${ }^{211}$ At 2012 production levels, the reserves-to-production ratio is 10 years, slightly longer than the PFC estimate.

\footnotetext{
${ }^{203}$ ibid.

${ }^{204}$ Republic of the Philippines Department of Energy, "Natural Gas."

${ }^{205}$ Malampaya website, "Power from the Deep," http://malampaya.com/.

${ }^{206}$ Guillermo R. Balce and Eric F. Pablico, Report on Philippine Natural Gas Resources: Maximizing Their Potential (Taguig, Phillippines: Republic of the Philippines Department of Energy, 1998), https://www.doe.gov.ph/fossilfuels/natural-gas/356-reports-natgas-01.

${ }^{207}$ Republic of the Philippines Department of Energy website, “Oil \& Gas," https://www.doe.gov.ph/fossil-fuels/oil-gas.

${ }^{208}$ Republic of the Philippines Department of Energy website, "Downstream Natural Gas Sector Plans \& Programs," https://www.doe.gov.ph/microsites/ngmd\%20website/gas_plans_programs.html.

${ }^{209}$ PFC Energy, Global LNG.

${ }^{210}$ Malampaya website, “Overview of Malampaya," http://malampaya.com/about/.

${ }^{211}$ Authors' calculations, based on initial reserve estimates and production (2001 to 2012) from: IEA, "World - Natural gas statistics."
} 
Current natural gas reserves in the Philippines were at 98.5 BCM in 2013 and, based on 2012 production, the reserves-to-production ratio is 25 years. ${ }^{212}$ However, this relies on current demand remaining constant, an unlikely occurrence, as well as these additional reserves being developed. The Philippines Department of Energy estimates recoverable discovered and undiscovered natural gas reserves of $292.9 \mathrm{BCM}^{213}$

PFC Energy estimates that the Philippines will develop a natural gas supply-demand gap equivalent to 2 MMTPA (2.7 BCM) by 2025 and 3 MMTPA (4 BCM) by $2030 .{ }^{214}$ Based on demand growth of 1.5 per cent per year from 2012, and constant production at 2012 volumes, a gap will open immediately (Figure A3.7). If production increases to meet demand, the Malampaya field will be exhausted in 2022; a greater rate of demand growth will mean exhaustion occurs sooner. In the absence of additional domestic production, imports (via pipeline or LNG) will be required to continue providing fuel to installed gas-fired power plants once production from Malampaya starts to decline.

FIGURE A3.7: PHILIPPINES' NATURAL GAS SUPPLY-DEMAND BALANCE

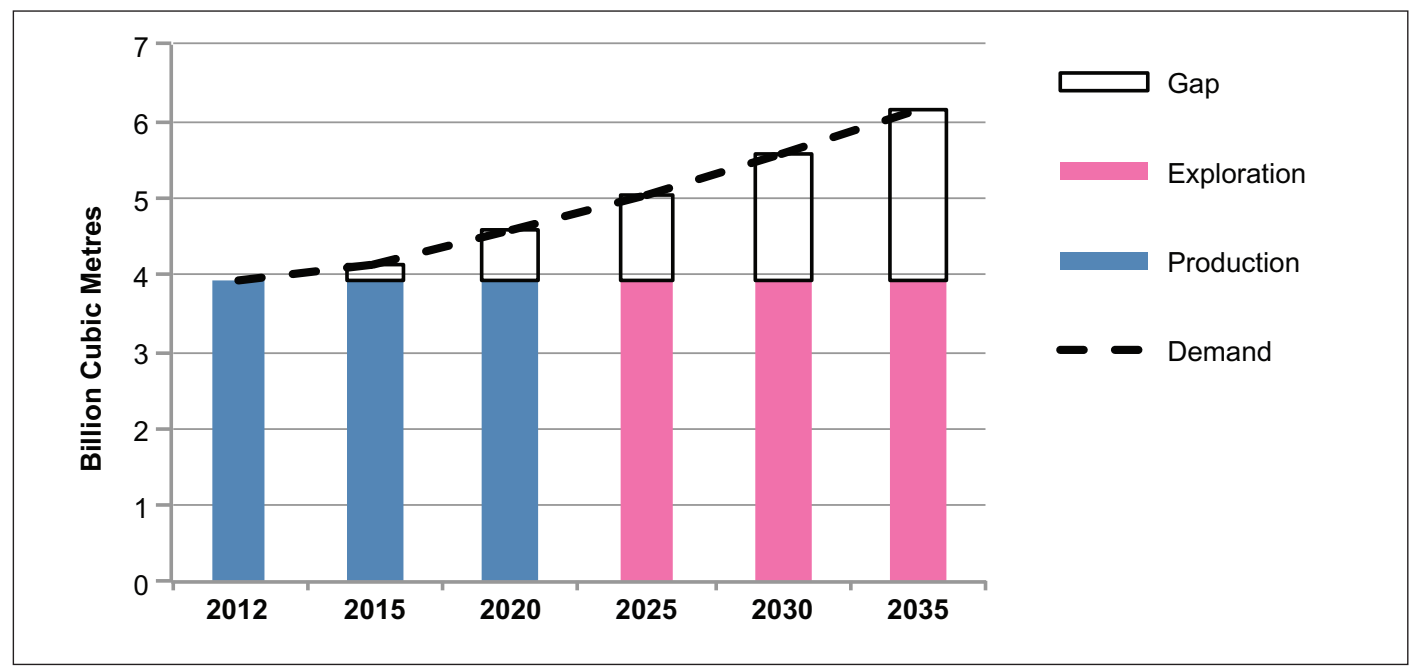

Notes: Production, imports and consumption (demand) data for 2012 from IEA, "World - Natural Gas statistics," IEA Natural Gas Information Statistics (database), 2013, doi: 10.1787/data-00482-en. Production is assumed to continue at 2012 volumes. An annual growth rate of 1.5 per cent for natural gas demand was used. Reserve estimates for Malampaya field are used to forecast production until the field is exhausted. Production from exploration assumes that other available reserves are developed.

\footnotetext{
${ }^{212}$ CIA World Factbook, "Philippines."

${ }^{213}$ Republic of the Philippines Department of Energy website, "Oil \& Gas."

${ }^{214}$ PFC Energy, Global LNG.
} 


\section{A3.2 THAILAND}

Thailand was the first country in Southeast Asia to import LNG. Thailand entered the ranks of LNG buyers in 2011, receiving deliveries from Indonesia, Nigeria, Peru, Qatar, and Russia. ${ }^{215}$ In 2012, Thailand imported 1.1 MMT of LNG in spot purchases from Yemen, Peru, Qatar, Nigeria and Trinidad. ${ }^{216}$ Thailand was unable to agree on the terms for long-term LNG purchases with an LNG supplier until December 2012, when it executed an agreement with Qatar. ${ }^{217}$ Under the terms of the agreement, Qatar will deliver 2 MMTPA to Thailand starting in 2015. ${ }^{218}$

In 2012, Thailand consumed 43 BCM of natural gas. Most of the natural gas was supplied by domestic producing fields in the Gulf of Thailand (31.3 BCM) and pipeline gas imports from Myanmar (9.7 BCM). ${ }^{219}$ Only three per cent of the natural gas consumed in 2012 came from LNG imports. However, if Thailand met all of its natural gas demand through LNG imports (the equivalent of 31.6 MMTPA) it would be the third-largest LNG importer in the world, just behind South Korea. ${ }^{220}$ Thailand anticipates importing increasing volumes of LNG to supplement and replace depleting domestic gas resources in the Gulf of Thailand and pipeline gas imports from Myanmar. ${ }^{221}$

Thailand has one LNG import terminal at Map Ta Phut, with capacity of 5 MMTPA. The Map Ta Phut terminal is operated by PTTLNG Company Ltd., which was established in 2004 and is wholly owned by PTT Public Company Ltd., Thailand's national oil and gas company. ${ }^{222} \mathrm{~A}$ doubling of its capacity and a second terminal are being planned. ${ }^{223}$ Thailand's LNG imports can be expected to grow to a substantial level, but the pace at which Thailand's LNG demand grows is highly dependent on how much pipeline gas will be available from the Gulf of Thailand, Myanmar and future imports that might become available from neighbouring Cambodia.

Domestic natural gas production has risen steadily in the past decade, although not enough to keep up with the growth in domestic consumption (Figure A3.4). Thailand had proved natural gas reserves of $284.9 \mathrm{BCM}$ at the start of $2013,{ }^{224}$ but these reserves have been in decline the last few years. ${ }^{225}$ Thailand's reserves-to-production ratio is nine years based on production volumes from 2012. Domestic production is expected to peak in 2017 and will be depleted by 2030 if there are no reserve additions. ${ }^{226}$

\footnotetext{
${ }^{215}$ IEA, "World - Natural Gas imports."

${ }^{216}$ Petroleum Economist, World LNG.

${ }^{217}$ Qatargas, “Qatargas 3 signs long-term agreement with PTT of Thailand,” press release, December 12, 2012, http://www.qatargas.com/English/MediaCenter/PressReleases/2012/Pages/12DecSPAwithPTT-PR.aspx.

${ }^{218}$ Bloomberg POTN (Poten \& Partners) LNG Contract Database.

${ }^{219}$ IEA, "World - Natural Gas imports"; and IEA, "World - Natural Gas statistics."

${ }^{220}$ Authors' calculations, based on: IEA, "World - Natural Gas imports"; and IEA, "World - Natural Gas statistics."

${ }^{221}$ EIA website, "Thailand," http://www.eia.gov/countries/cab.cfm?fips=TH

${ }^{222}$ PTT LNG website, "Welcome," http://www.pttlng.com/en/Default.aspx.

${ }^{223}$ PTT LNG website, “Company Information” http://www.pttlng.com/en/pj_composition.aspx.

${ }^{224}$ CIA World Factbook, "Thailand," https://www.cia.gov/library/publications/the-world-factbook/geos/th.html.

${ }^{225}$ EIA website, "Thailand," http://www.eia.gov/countries/cab.cfm?fips=TH.

${ }^{226}$ ibid.
} 
FIGURE A3.8: THAILAND'S NATURAL GAS PRODUCTION AND CONSUMPTION (1970 - 2012)

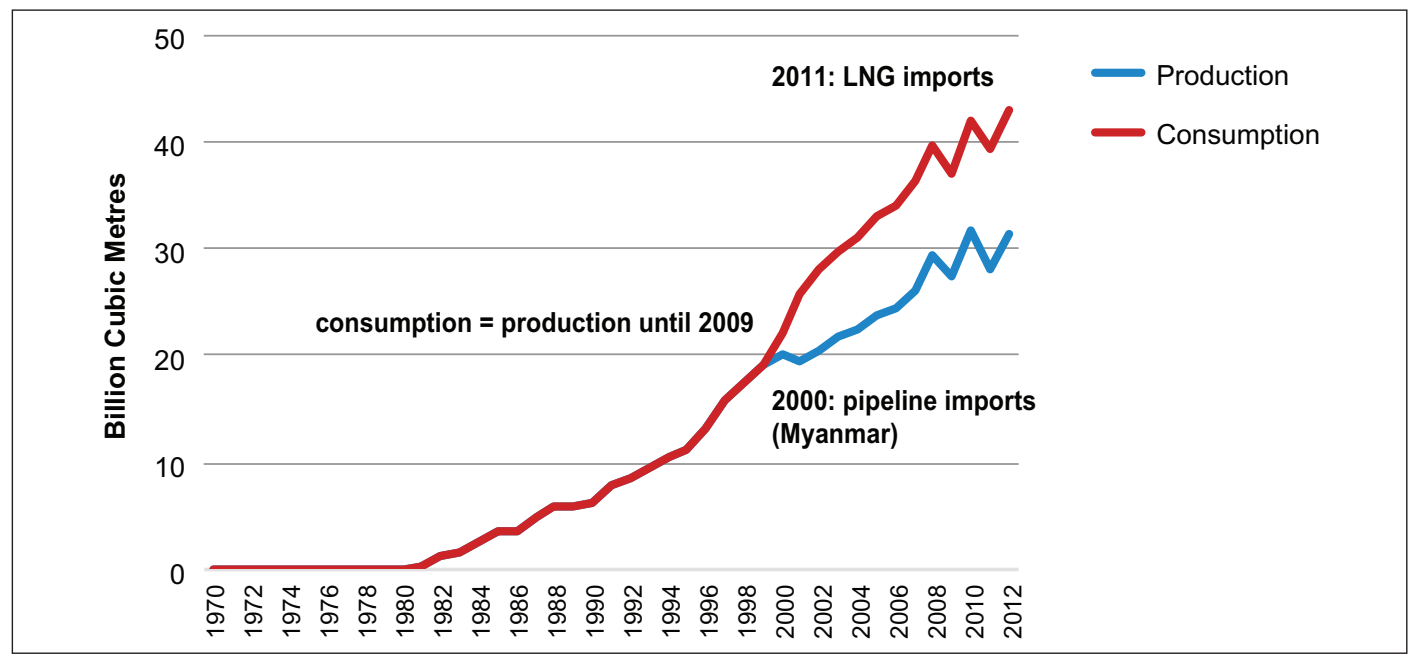

IEA, “World - Natural Gas statistics," IEA Natural Gas Information Statistics (database), 2013, doi: 10.1787/data-00482-en.

The power sector accounts for about 60 per cent of natural gas demand in Thailand, although this share has declined since 2000 as other sectors have increased their use of natural gas. ${ }^{227}$ Gas-fired facilities supplied 71 per cent of Thailand's domestic electricity supply in 2011, and coal- and lignite-fueled plants supplied a 21 per cent share. ${ }^{228}$ The government's powerdevelopment plan aims to diversify the fuel mix by building nuclear power plants and more renewable power plants. ${ }^{229}$

However, post-Fukushima, construction of nuclear plants seems unlikely, as the first proposed nuclear facility was scaled back in size and has been delayed until at least $2026 .{ }^{230}$ Even with optimistic projections for nuclear and renewables, the government projects that natural gas demand will increase 1.5 per cent per year to $72.3 \mathrm{BCM}$ per year by $2022 .{ }^{231}$

Thailand is seeking to secure additional gas supplies through increased domestic production and additional pipeline gas imports. However, the Gulf of Thailand is a very mature producing region with limited remaining potential. Thailand's natural gas imports from Myanmar peaked in 2010 at 10.5 BCM. ${ }^{232}$ There are two pipelines supplying gas from Myanmar's Yadana and Yetagun fields, and PTT Exploration and Production Company Ltd. is producing from an additional field, but construction for the pipeline link to Thailand is not yet complete. ${ }^{233}$ The EIA notes that Myanmar's own domestic gas needs are increasing, which may affect future exports to Thailand. ${ }^{234}$ In addition, China began importing pipeline gas from Myanmar in 2013, so additional imports from Myanmar are not assured. ${ }^{235}$

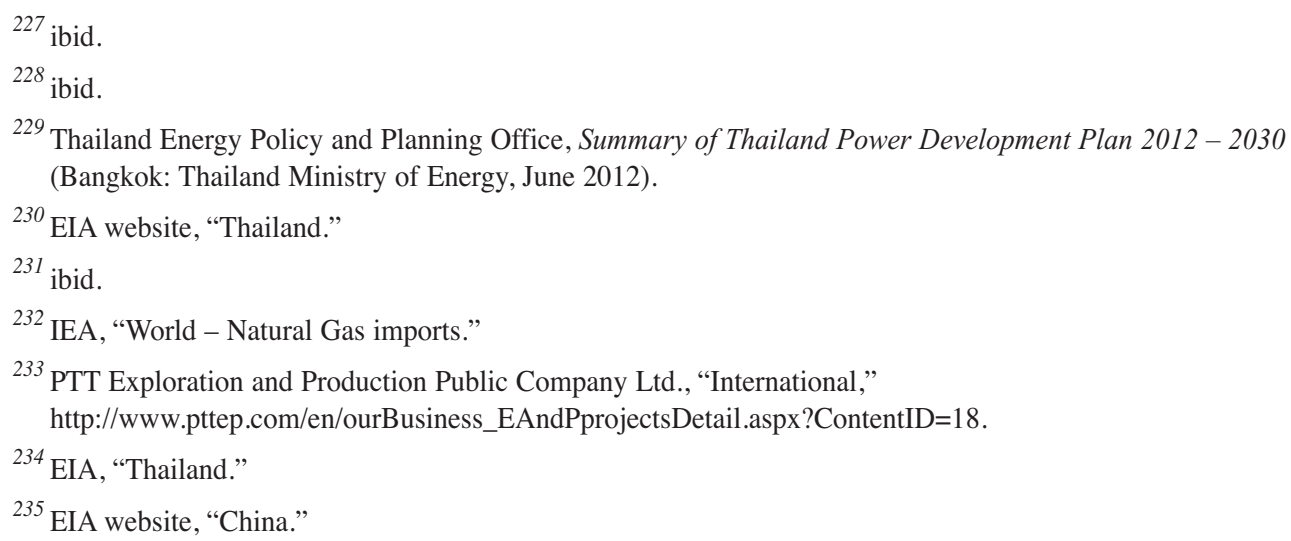


Despite this increase in pipeline gas imports, PFC Energy believes that additional LNG imports will be required to meet Thailand's natural gas demand. ${ }^{236} \mathrm{PFC}$ expects that Thailand will need an additional 11 MMTPA (15 BCM) of natural gas by 2020. We calculate the gap to be 4.3 BCM (3.1 MMT) in 2020, and the gap opens up substantially in 2025 due to the assumed exhaustion of reserves.

\section{FIGURE A3.9: THAILAND'S NATURAL GAS SUPPLY-DEMAND BALANCE}

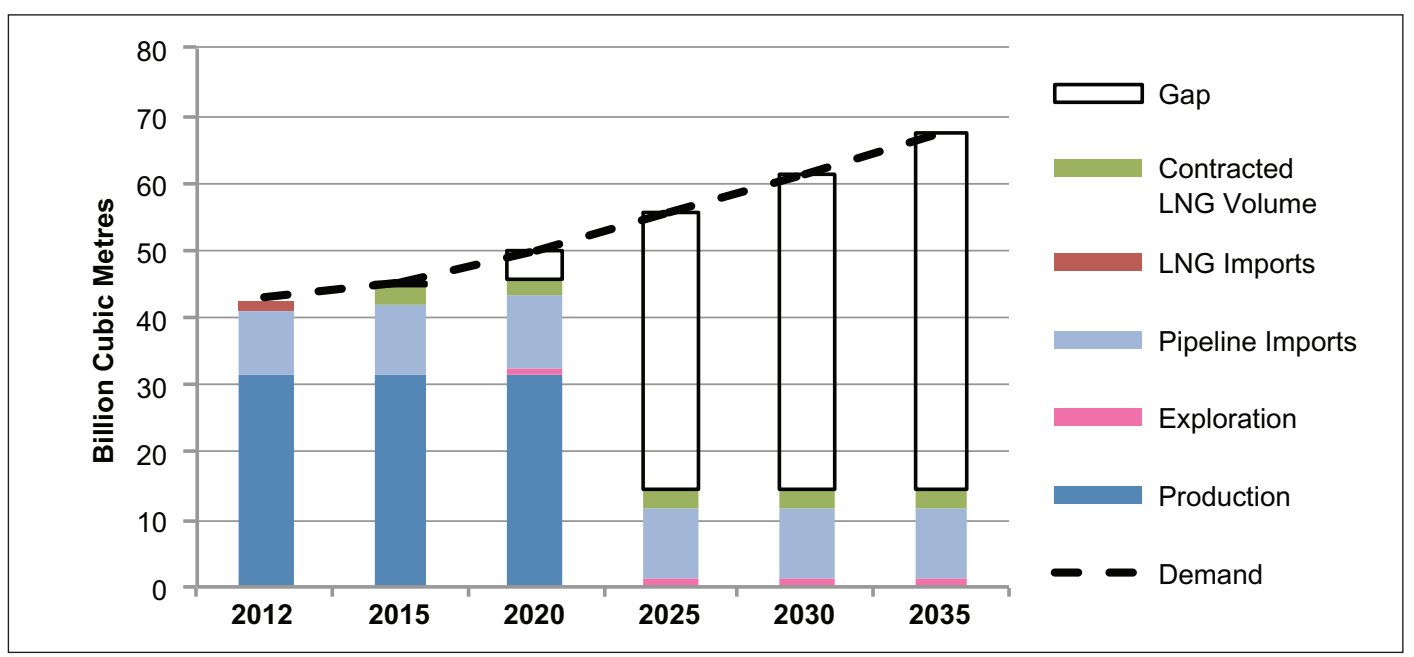

Notes: Production, imports and consumption (demand) data for 2012 from IEA, "World - Natural Gas statistics," IEA Natural Gas Information Statistics (database), 2013, doi: 10.1787/data-00482-en. Production is assumed to continue at 2012 volumes until reserves are exhausted. Pipeline supplies post-2012 are based on the maximum imports in 2010. Exploration data come from the ElA's description of Ubon field (ElA website "Thailand," http://www.eia.gov/countries/cab.cfm?fips=TH). An annual growth rate of 1.5 per cent for natural gas demand was used. Contract volumes are from Bloomberg POTN (Poten \& Partners) LNG contract database.

\section{A3.5 SINGAPORE}

Singapore is a small, prosperous, island city-state located at the southern tip of Peninsular Malaysia, across the Malacca Strait from the Indonesian island of Sumatra. Singapore has no oil or gas resources. For its natural gas supply, Singapore is entirely reliant on imported pipeline gas from Sumatra, Indonesian territorial waters in the Natuna Sea, and Peninsular Malaysia. ${ }^{237}$ In 2012, Singapore consumed 9.4 BCM of imported natural gas. ${ }^{238}$

\footnotetext{
${ }^{236}$ PFC Energy, Global LNG.

${ }^{237}$ EIA website, “Singapore," http://www.eia.gov/countries/cab.cfm?fips=SN.

${ }^{238}$ IEA, "World - Natural gas statistics."
} 


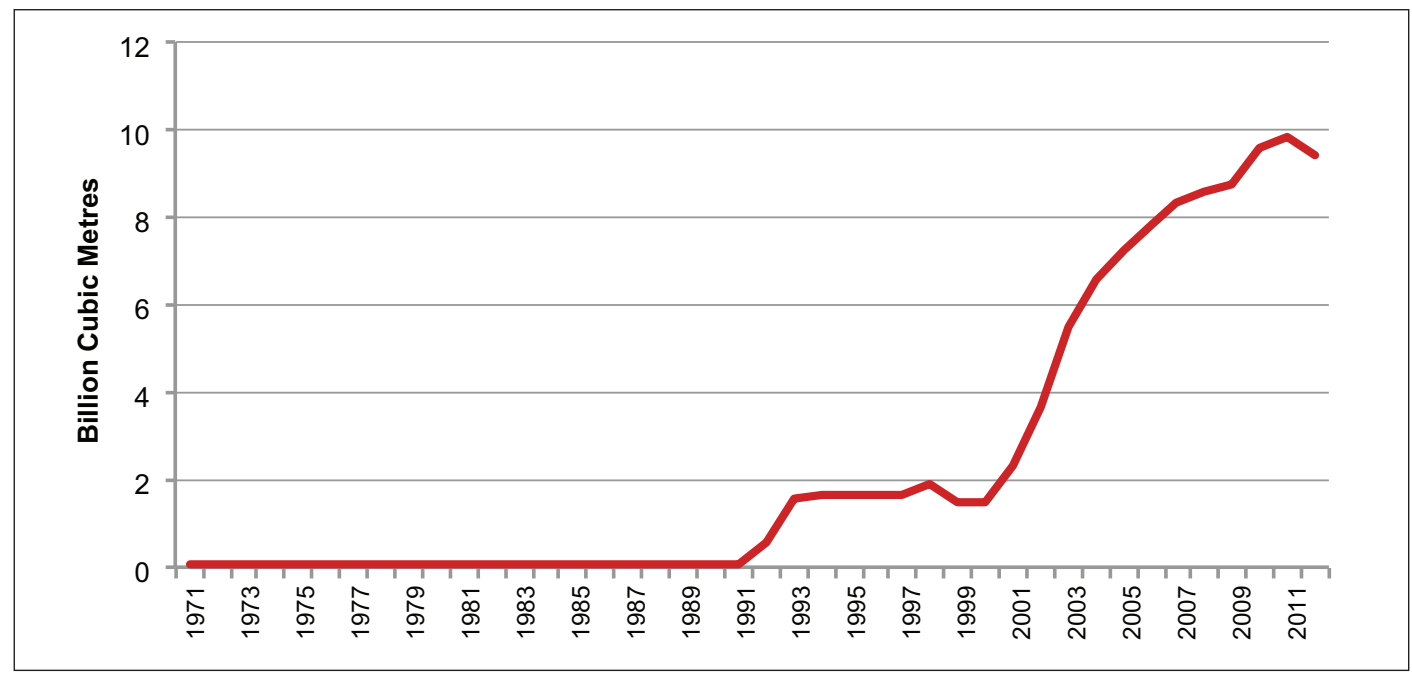

Source: IEA, “World - Natural Gas statistics," IEA Natural Gas Information Statistics (database), 2013, doi: 10.1787/data-00482-en.

The government of Singapore promotes the use of natural gas through vehicle rebates and targets for power generation. ${ }^{239}$ In 2001, the government also set a target to generate 60 per cent of the country's electricity from gas-fired power plants by 2012; Singapore met this target in $2003 .{ }^{240}$ The share of natural gas in power generation reached 78 per cent in $2011 .^{241}$

Singapore shifted abruptly from not using natural gas as an electricity source at all in 1990, to 91 per cent of natural gas going to power generation in $2000 .^{242}$ The share of natural gas going to power generation has decreased since then, with only 85 per cent of natural gas going to the power sector in $2011 .^{243}$ Installed generation capacity was 10.5 gigawatts $(\mathrm{GW})$ in 2012 , with plans to add $3 \mathrm{GW}$ by $2017 .{ }^{244}$ The additional capacity will be supplied by imported LNG. ${ }^{245}$

In 2006, the government of Singapore announced its decision to build an LNG import terminal to diversify its sources of natural gas and meet its rising future demand. ${ }^{246} \mathrm{BG}$ Asia-Pacific Pte Ltd. was granted an exclusive license to import, regasify and market up to 3.1 MMTPA (4.2 BCM) of LNG into Singapore. ${ }^{247}$ Singapore LNG, a subsidiary of the Energy Market Authority, was assigned to develop and operate the terminal. ${ }^{248}$ Construction of the terminal began in 2010, and the terminal received its first cargo in March 2013, with commercial operations starting in May 2013. ${ }^{249}$

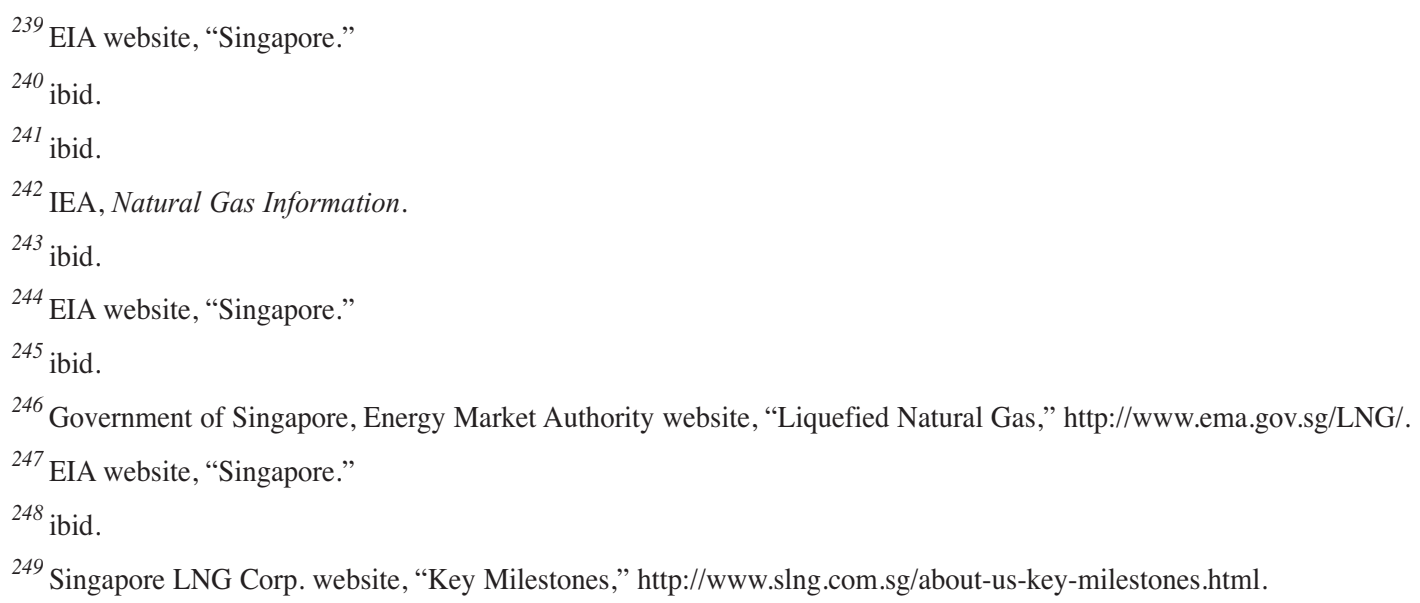


The terminal had an initial capacity of 3.5 MMTPA, increasing to 6 MMTPA with the addition of a third tank and additional regasification facilities. ${ }^{250}$ Plans for a fourth tank and additional regasification facilities were announced in October 2012, which would raise its capacity to 9 MMTPA. ${ }^{251}$ A second LNG terminal is also being considered. ${ }^{252}$ Current pipeline contracts with Malaysia and Indonesia supply up to $9.4 \mathrm{BCM}$ of natural gas per year. ${ }^{253}$ The first of these will expire in 2017, with the others continuing until 2021, 2022 and $2023 .{ }^{254}$

According to PFC Energy, Singapore's natural gas demand can be met in the near term with its existing pipeline gas and LNG contracts. ${ }^{255} \mathrm{PFC}$ forecasts that the supply-demand gap will reach 6 MMTPA by 2025, and 8 MMTPA by 2030. As seen in Figure A3.11, the existing pipeline and LNG contracts are more than sufficient until 2020; this would be the case even with two per cent annual demand growth. With the expiry of the pipeline contracts, the supply gap is 7.2 BCM in 2025. However, if the pipeline contracts with Indonesia are renewed, this would provide 7 BCM of natural gas supply. Combined with existing LNG contracts, the supply gap would be relatively minor.

\section{FIGURE A3.11: SINGAPORE'S NATURAL GAS SUPPLY-DEMAND BALANCE}

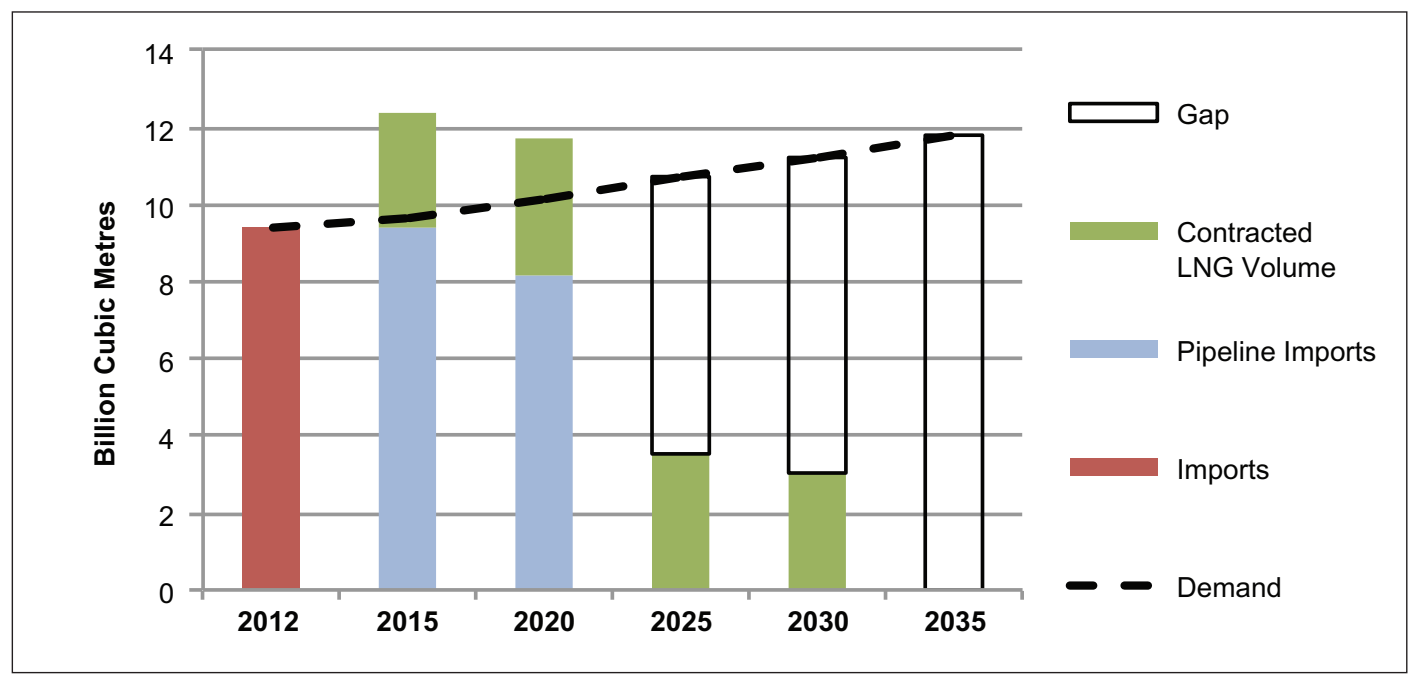

Notes: Production, imports and consumption (demand) data for 2012 from IEA, "World - Natural Gas statistics," IEA Natural Gas Information Statistics (database), 2013, doi: 10.1787/data-00482-en. Pipeline supplies post-2012 are based on the contracts described in the EIA's Singapore country analysis (EIA website, "Singapore," http://www.eia.gov/countries/cab.cfm?fips=SN). An annual growth rate of one per cent for natural gas demand was used. Contract volumes are from Bloomberg POTN (Poten \& Partners) LNG contract database.

\footnotetext{
${ }^{250}$ Government of Singapore, Energy Market Authority website, "Liquefied Natural."

${ }^{251}$ Singapore LNG Corp. website, "Key Milestones."

${ }^{252}$ Chou Hui Hong and Ramsey Al-Rikabi, "Singapore Bids for Role as LNG Hub With Second Terminal," Bloomberg, February 25, 2014.

${ }^{253}$ EIA website, "Singapore."

${ }^{254}$ ibid.

${ }^{255}$ PFC Energy, Global LNG.
} 


\section{A3.7 VIETNAM}

According to the EIA, Vietnam has become an important oil and natural gas producer in Southeast Asia. ${ }^{256}$ Increased domestic energy consumption was spurred by Vietnam's rapid economic growth and industrialization, as well as expanded export markets. ${ }^{257}$ The power sector is the largest gas consumer in Vietnam, accounting for 94 per cent of gas demand in 2011..$^{258}$

Vietnam produced 9.9 BCM of natural gas in 2012, all of which was consumed domestically. ${ }^{259}$ Vietnam's proved natural gas reserves increased threefold in the last 10 years, from 200 BCM in 2003 to 600 BCM in 2012. ${ }^{260}$ The CIA World Factbook reports Vietnam's reserves at 699 $\mathrm{BCM}$ at the start of $2013 .{ }^{261}$ Based on 2012 production, the reserves-to-production ratio is 70 years. However, as shown in Figure A3.12, consumption has recently overshot production, and as consumption continues to increase, production must as well, reducing the expected lifetime of current reserves. According to the EIA, the state-owned Vietnam Oil and Gas Corp.

(PetroVietnam) expects a natural gas supply gap of 13.4 BCM per year by $2025 .{ }^{262}$

FIGURE A3.12: VIETNAM'S NATURAL GAS PRODUCTION AND CONSUMPTION (1980 - 2012)

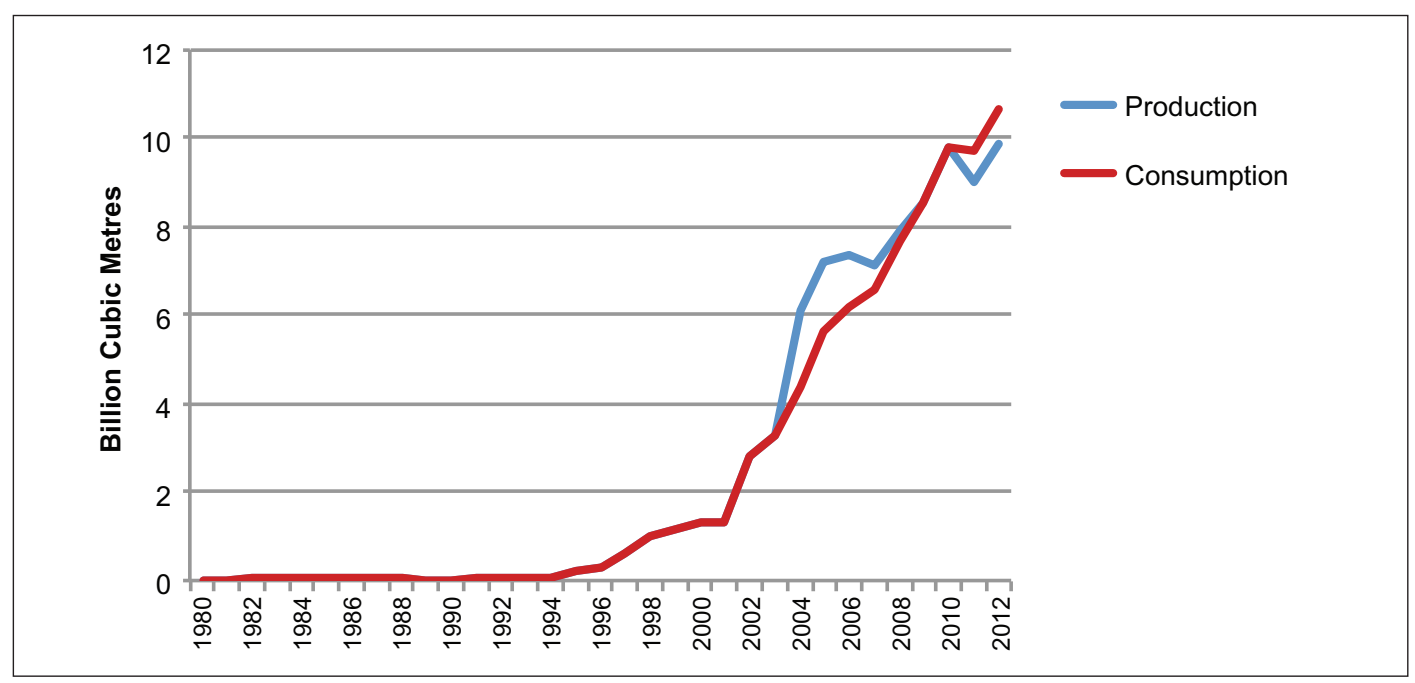

Source: IEA, “World - Natural Gas statistics," IEA Natural Gas Information Statistics (database), 2013, doi: 10.1787/data-00482-en.

PFC Energy expects domestic gas production to increase until 2020; development of exploration successes will be required to continue production growth rates beyond this period. ${ }^{263}$ Ongoing exploration activities could increase Vietnam's reserves as offshore areas have been relatively underexplored. ${ }^{264}$

\footnotetext{
${ }^{256}$ EIA website, "Vietnam," http://www.eia.gov/countries/country-data.cfm?fips=VM.

${ }^{257}$ EIA website, "Vietnam."

${ }^{258}$ IEA, Natural Gas Information.

${ }^{259}$ IEA, "World - Natural gas statistics."

${ }^{260}$ BP, BP Statistical Review (2013).

${ }^{261}$ CIA World Factbook, "Vietnam," https://www.cia.gov/library/publications/the-world-factbook/geos/vm.html.

${ }^{262}$ EIA website, "Vietnam."

${ }^{263}$ PFC Energy, Global LNG.

${ }^{264}$ EIA website, "Vietnam."
} 
Importing LNG to meet growing natural gas demand is an option being considered by Vietnam's government. ${ }^{265}$ Royal Haskoning, a Vietnamese consulting firm, was selected to complete a site-selection study for an LNG import terminal, comparing four potential sites: Phu Long Island, Soai Rap, Son My and Vinh Tan. ${ }^{266}$ PetroVietnam has signed an agreement with Gazprom to supply the 1-MMTPA Thi Vai facility, which is expected to be operational in $2017 .{ }^{267}$ In addition, PV Gas is planning to build a second terminal at Son My, with initial capacity of 1.8 MMTPA in $2020 .{ }^{268}$ Planned capacity increases are an additional 1.8 MMTPA by 2020 , with total capacity reaching 6 MMTPA in 2023 and 9.6 MMTPA by $2030 .{ }^{269}$ Whether either terminal is ever constructed will depend to a large extent on the success of Vietnam's ongoing exploration and development activities.

PFC Energy finds that prospects for LNG imports into Vietnam are fairly minor before 2025, at 2 to 3 MMTPA, with the potential to increase this amount to 5 to 8 MMTPA by $2030 .^{270}$ Figure A3.13 shows that the gap opens slightly in 2015, assuming production is slightly below demand. A gap of 1.8 BCM occurs in 2025 as production levels off.

\section{FIGURE A3.13: VIETNAM'S NATURAL GAS SUPPLY-DEMAND BALANCE}

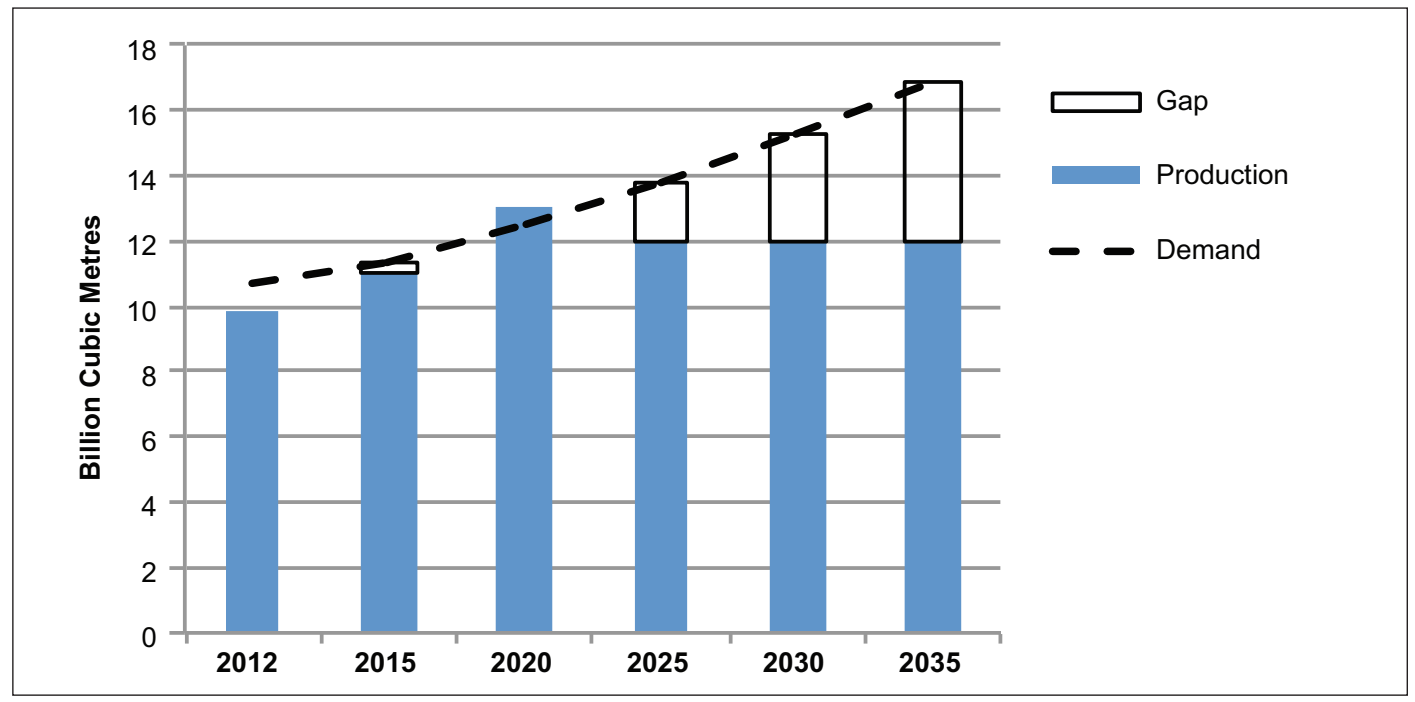

Notes: IEA, “World - Natural Gas statistics," IEA Natural Gas Information Statistics (database), 2013, doi: 10.1787/data-00482-en. Forecast production volumes from IEA, Southeast Asia Energy Outlook: World Energy Outlook Special Report (Washington, D.C.: ElA, September 2013). An annual growth rate of two per cent for natural gas demand was used.

\footnotetext{
265 ibid.

${ }^{266}$ Royal Haskoning website, "Vietnam LNG Receiving Terminal,” http://www.royalhaskoning.com.vn/en$\mathrm{gb} /$ fields/InfrastructureAndPorts/Pages/VietnamLNGReceivingTerminal.aspx.

${ }^{267}$ Dao Dang Toan, “Vietnam's PV Gas inks deal to buy LNG from Gazprom's Singapore unit," Platts, March 7, 2014, http://www.platts.com/latest-news/natural-gas/hanoi/vietnams-pv-gas-inks-deal-to-buy-lng-from-gazproms-27006980.

${ }^{270}$ PFC Energy, Global LNG.
} 


\section{APPENDIX B: NATURAL GAS CHARACTERISTICS}

This report deals with LNG as a market-changing phenomenon, but it is important to note that LNG is a way to transport natural gas, and not a product unto itself. The demand for and the nature of LNG markets are rooted in the demand for natural gas as a fuel or feedstock. In this capacity, natural gas is used as a fuel for power generation, residential and commercial heating, and in the form of compressed natural gas (CNG) and LNG for commercial vehicles and light or passenger vehicles.

In addition to fuel uses, there are a variety of demands for natural gas in the chemical industry where it can be reformed and used in compounds from plastics to hydrogen production (for hydrocracking, hydro-desulfurization, and ammonia) and for syngas (for methanol, and its derivatives, such as methyl tertiary butyl ether (MTBE), formaldehyde, and acetic acid).

\section{Natural Gas and Derivatives}

Natural gas is a naturally occurring hydrocarbon-gas mixture consisting primarily of methane, but commonly includes varying amounts of other higher alkanes and even a lesser percentage of carbon dioxide, nitrogen, and hydrogen sulfide. The natural gas transportation systems pipelines and LNG - require that the produced gas be processed to remove water, hydrogen sulfide, carbon dioxide and other impurities.

Gas obtained from field wells can range from "dry" to "wet," depending on the field. Dry natural gas is primarily methane with only small amounts of heavier hydrocarbons, and thus lacking condensate or liquid hydrocarbons. Wet gas is natural gas that flows from the well containing less methane and heavier hydrocarbons. These heavier hydrocarbons are classified as natural gas liquids (NGLs) and condensate. NGLs include propane, butane, pentane, hexane and heptane. NGLs do not include methane and ethane, since these hydrocarbons must be chilled substantially and continuously to become liquefied. The other byproduct of natural gas production is condensate, a low-density mixture of $\mathrm{C}_{5+}$ hydrocarbon liquids that condense out of the raw gas if temperature and pressure are reduced to below the hydrocarbon dew-point temperature of the raw gas.

\section{Natural Gas Liquids and Condensate}

NGLs comprise a portion of the petroleum market that occupies a space between oil and gas products, with values and market characteristics that are similar but still distinct from these two commodities. The majority of NGLs are derived from gas production, whether associated with crude oil production, or solely on its own non-associated gas production. ${ }^{l}$ Primarily, NGLs reflect gas characteristics and need special containment to remain in a liquid state. As noted above, NGLs are ethane $\left(\mathrm{C}_{2}\right)$, propane $\left(\mathrm{C}_{3}\right)$, normal butane $\left(\mathrm{NC}_{4}\right)$, isobutane (IC4) and natural gasoline $\left(\mathrm{C}_{5+}\right)$. Generally, when at least 90 per cent of the NGL stream has only one type of carbon molecule, it is defined as a purity product. Propane and butane, either as purity products or "in mix," are also called liquid petroleum gas (LPG) and are usually marketed as LPG. LPG is also produced by petroleum refineries.

\footnotetext{
All natural gas contains some NGLs. Sometimes there are enough NGLs to be recovered economically, sometimes not. Sometimes NGLs must be removed (whether economical or not) for the "residue" natural gas to meet heatcontent and other specifications for the takeaway natural gas pipeline or LNG liquefaction facility.
} 
As with all products meeting the literal, international definition of natural gas liquids, condensate consists of "wet" or liquid hydrocarbon molecules suspended in natural gas at subsurface temperature and pressure. Unlike ethane or LPG, a substantial volume of condensate naturally precipitates or falls out of the gas stream immediately after exiting the wellhead, usually into a stabilizer vessel, while the remaining condensate is typically recovered through NGL processing.

Condensate is a very light form of hydrocarbon that condenses in liquid form at the wellhead and has a high range of API gravity of 55 degrees or higher. Once it becomes a liquid, condensate remains a liquid at atmospheric temperatures. It is usually quite low in sulphur and typically produces a 50 per cent or greater naphtha yield, as well as distillate.

\section{Importance of The Heating Value of Natural Gas}

The heating value of natural gas is the amount of heat generated per unit of gas volume when the gas is burned. In using natural gas as a fuel, from gas turbines to home heating to internal combustion engines, the application is designed for a specific heating value of natural gas. Proper and stable combustion of natural gas requires that the correct heating-value gas be used. The reason is that, as gas becomes richer (higher heating value), more air per unit volume of natural gas is required for proper combustion; as the gas gets leaner (lower heating value), less air per unit of gas is required. Applications that use gas for fuel utilize fixed ratios of air to gas at the point of combustion, and using the wrong gas will cause poor or even dangerous combustion of the gas.

Table B1 reports average calorific values of natural gas produced, imported, exported and consumed by country. Calorific value is another term used to describe energy per volume, or the heat value. Based on consumption, there is quite a range in gas quality, with a minimum of $32 \mathrm{MJ} / \mathrm{m}^{3}$ (Pakistan) to a maximum of $48 \mathrm{MJ} / \mathrm{m}^{3}$ (Ecuador). The range of heating values across regions, however, is remarkably similar.

It is important to note however, that a country's total consumption includes required heating values that can differ across uses (home heating versus electricity generation, for example). The average calorific value based on different uses will depend on the share of natural gas consumed by each source of demand, as well as the required heating value for each use. 
TABLE B1: AVERAGE GROSS CALORIFIC VALUE OF NATURAL GAS (MJ/M³)

\begin{tabular}{|c|c|c|c|c|}
\hline & Production & Imports & Exports & Consumption \\
\hline World Average & 38.24 & 38.63 & 38.09 & 38.65 \\
\hline \multicolumn{5}{|l|}{ Asia-Pacific } \\
\hline Australia & 40.68 & 40.00 & 40.00 & 39.31 \\
\hline Brunei Darussalam & 40.07 & & 40.07 & 40.07 \\
\hline China, People's Republic & 38.93 & 38.93 & 38.93 & 38.93 \\
\hline Hong Kong (China) & & 38.00 & & 38.00 \\
\hline Indonesia & 40.60 & & 40.60 & 40.60 \\
\hline Japan & 44.51 & 38.98 & & 39.34 \\
\hline Korea & 41.70 & 41.69 & & 41.90 \\
\hline Malaysia & 39.25 & 39.25 & 39.25 & 39.25 \\
\hline Myanmar & 39.27 & & 39.27 & 39.27 \\
\hline New Zealand & 37.72 & & & 37.72 \\
\hline Philippines & 38.36 & & & 38.36 \\
\hline Singapore & & 38.00 & & 38.00 \\
\hline Taiwan & 37.26 & 41.45 & & 41.19 \\
\hline Thailand & 36.40 & 36.40 & & 36.40 \\
\hline Vietnam & 38.61 & & 38.61 & 38.61 \\
\hline Other Asia-Pacific & 38.00 & 38.00 & 38.00 & 38.00 \\
\hline Average & 39.38 & 39.07 & 39.34 & 39.06 \\
\hline \multicolumn{5}{|l|}{ The Americas } \\
\hline Canada & 38.39 & 38.39 & 38.39 & 38.43 \\
\hline Argentina & 38.95 & 38.95 & 38.95 & 38.95 \\
\hline Bolivia & 38.94 & & 38.94 & 38.94 \\
\hline Brazil & 39.43 & 39.43 & & 39.43 \\
\hline Chile & 39.10 & 39.10 & 0.00 & 39.10 \\
\hline Colombia & 34.60 & & 34.60 & 34.60 \\
\hline Cuba & 36.96 & & & 36.96 \\
\hline Dominican Republic & & 38.00 & & 38.00 \\
\hline Ecuador & 48.44 & & & 48.44 \\
\hline Mexico & 38.44 & 38.50 & 39.25 & 38.43 \\
\hline Peru & 44.92 & & 44.92 & 44.92 \\
\hline Trinidad and Tobago & 38.94 & & 38.94 & 38.94 \\
\hline Venezuela & 44.38 & 44.38 & & 44.38 \\
\hline United States & 38.22 & 38.15 & 37.64 & 38.22 \\
\hline Uruguay & & 38.00 & & 38.00 \\
\hline Other Non-OECD Americas & 38.00 & 38.00 & & 38.00 \\
\hline Average & 39.83 & 39.09 & 34.63 & 39.61 \\
\hline
\end{tabular}

Note: Average for each country calculated for values from 2006 through 2011.

Source: IEA, Natural Gas Information (2013), xxix-xxx. 
TABLE B1: AVERAGE GROSS CALORIFIC VALUE OF NATURAL GAS (MJ/M³) (cont'd)

\begin{tabular}{|c|c|c|c|c|}
\hline & Production & Imports & Exports & Consumption \\
\hline \multicolumn{5}{|l|}{ Europe } \\
\hline Albania & 38.89 & & & 38.89 \\
\hline Austria & 38.00 & 38.02 & 38.00 & 38.02 \\
\hline Belarus & 38.62 & 38.62 & & 38.62 \\
\hline Belgium & & 39.69 & 39.43 & 39.69 \\
\hline Bosnia-Herzegovina & & 37.86 & & 37.86 \\
\hline Bulgaria & 36.19 & 38.04 & & 37.88 \\
\hline Croatia & 3.79 & 37.79 & 37.78 & 37.79 \\
\hline Czech Republic & 37.63 & 38.05 & 38.05 & 38.04 \\
\hline Denmark & 41.61 & 41.59 & 41.61 & 41.61 \\
\hline Estonia & & 37.85 & & 37.85 \\
\hline Finland & & 37.89 & & 37.89 \\
\hline France & 38.65 & 40.33 & 40.30 & 40.34 \\
\hline Germany & 34.22 & 38.99 & 38.99 & 38.08 \\
\hline Greece & 49.36 & 38.71 & & 38.79 \\
\hline Hungary & 35.68 & 38.12 & 38.56 & 37.59 \\
\hline Ireland & 37.81 & 39.91 & & 40.11 \\
\hline Italy & 38.10 & 38.10 & 38.10 & 38.10 \\
\hline Republic of Macedonia & & 37.58 & & 37.55 \\
\hline Latvia & & 37.30 & & 37.30 \\
\hline Lithuania & & 37.21 & & 37.21 \\
\hline Luxembourg & & 40.71 & & 40.71 \\
\hline Moldova, Republic & & 35.79 & & 35.78 \\
\hline Netherlands & 33.34 & 33.34 & 33.34 & 33.34 \\
\hline Norway & 39.71 & & 39.71 & 39.71 \\
\hline Poland & 29.35 & 38.08 & 37.75 & 35.20 \\
\hline Serbia & 36.92 & 37.38 & & 37.33 \\
\hline Slovak Republic & 40.03 & 38.14 & 39.11 & 38.15 \\
\hline Slovenia & 39.92 & 37.86 & & 37.87 \\
\hline Spain & 40.18 & 40.37 & 40.39 & 40.34 \\
\hline Sweden & & 41.86 & & 41.86 \\
\hline Switzerland & & 38.09 & & 38.09 \\
\hline Portugal & & 40.55 & & 40.55 \\
\hline Romania & 37.03 & 37.07 & & 36.90 \\
\hline Russian Federation & 38.23 & 38.23 & 38.23 & 38.23 \\
\hline United Kingdom & 39.86 & 39.55 & 39.55 & 39.75 \\
\hline Ukraine & 36.99 & 38.49 & 37.26 & 37.97 \\
\hline Average & 36.67 & 38.45 & 38.60 & 38.36 \\
\hline
\end{tabular}

Note: Average for each country calculated for values from 2006 through 2011. 
TABLE B1: AVERAGE GROSS CALORIFIC VALUE OF NATURAL GAS (MJ/M³) (cont'd)

\begin{tabular}{|c|c|c|c|c|}
\hline & Production & Imports & Exports & Consumption \\
\hline \multicolumn{5}{|l|}{ Africa } \\
\hline Algeria & 42.00 & & 42.00 & 42.00 \\
\hline Angola & 38.00 & & & 38.00 \\
\hline Cameroon & 38.00 & & & 38.00 \\
\hline Congo & 38.00 & & & 38.00 \\
\hline Congo, Democratic Republic & 38.00 & & & 38.00 \\
\hline Cote d'Ivoire & 37.28 & & & 37.28 \\
\hline Egypt & 38.00 & & 38.00 & 38.00 \\
\hline Gabon & 37.70 & & & 37.70 \\
\hline Ghana & & 38.00 & & 38.00 \\
\hline Libya & 38.00 & & 38.00 & 38.00 \\
\hline Morocco & 39.17 & 39.17 & & 39.17 \\
\hline Mozambique & 38.00 & & 38.00 & 38.00 \\
\hline Nigeria & 38.00 & & 38.00 & 38.00 \\
\hline Senegal & 33.49 & & & 33.49 \\
\hline South Africa & 38.00 & 38.00 & & 38.00 \\
\hline Tanzania, United Republic & 38.00 & & & 38.00 \\
\hline Tunisia & 43.73 & 39.75 & & 42.60 \\
\hline Other Africa & 38.00 & 38.00 & 38.00 & 38.00 \\
\hline Average & 38.32 & 38.58 & 38.67 & 38.24 \\
\hline \multicolumn{5}{|l|}{ Western Asia } \\
\hline Armenia & & 37.70 & 37.70 & 37.70 \\
\hline Azerbaijan & 38.99 & 39.02 & 38.99 & 38.99 \\
\hline Bahrain & 38.00 & & & 38.00 \\
\hline Georgia & 35.53 & 39.66 & & 39.61 \\
\hline Iran, Islamic Republic & 39.36 & 39.36 & 39.36 & 39.36 \\
\hline Iraq & 38.00 & & & 38.00 \\
\hline Israel & 37.97 & 38.43 & & 37.95 \\
\hline Jordan & 36.82 & 38.06 & & 38.00 \\
\hline Kuwait & 38.00 & 38.00 & & 38.00 \\
\hline Lebanon & & 38.90 & & 38.90 \\
\hline Qatar & 41.40 & & 41.40 & 41.40 \\
\hline Oman & 38.00 & 38.00 & 38.00 & 38.00 \\
\hline Saudi Arabia & 38.00 & & & 38.00 \\
\hline Syrian Arab Republic & 37.70 & 37.70 & & 37.70 \\
\hline Turkey & 38.30 & 38.45 & 38.33 & 38.48 \\
\hline Yemen & 40.60 & & 40.60 & 40.60 \\
\hline United Arab Emirates & 39.00 & 38.00 & 39.00 & 39.00 \\
\hline Average & 38.38 & 38.44 & 39.17 & 38.69 \\
\hline
\end{tabular}

Note: Average for each country calculated for values from 2006 through 2011.

Source: IEA, Natural Gas Information (2013), xxix-xxx. 
TABLE B1: AVERAGE GROSS CALORIFIC VALUE OF NATURAL GAS (MJ/M³) (cont'd)

\begin{tabular}{|l|c|c|c|c|}
\hline & Production & Imports & Exports & Consumption \\
\hline Central Asia & & & & \\
Kazakhstan & 40.11 & 39.02 & 39.02 & 42.07 \\
Kyrgyzstan & 39.02 & 39.02 & & 39.02 \\
Tajikistan & 38.00 & 38.00 & & 38.00 \\
Turkmenistan & 37.70 & & 37.70 & 37.70 \\
Uzbekistan & 37.89 & 37.89 & 37.89 & 37.89 \\
Average & 38.54 & 38.48 & 38.20 & 38.94 \\
South Asia & & & & \\
Bangladesh & 38.64 & & & 38.64 \\
India & 38.54 & 38.78 & & 38.76 \\
Pakistan & 32.31 & 38.78 & & 36.31 \\
Average & 36.49 & 36.5 & \\
\hline
\end{tabular}

Note: Average for each country calculated for values from 2006 through 2011.

Source: IEA, Natural Gas Information (2013), xxix-xxx.

Table B2 shows the calorific value of gas supplied from various LNG terminals around the world. Note that even the driest gas, from Alaska, has a calorific value greater than gas from Canada (shown above in Table B1).

\section{TABLE B2: LNG CALORIFIC VALUE BY TERMINAL}

\begin{tabular}{|c|c|c|}
\hline Origin & Gas GCV MJ/m³ $(n)$ & Gas GCV MJ $/ \mathrm{m}^{3}(\mathrm{~s})$ \\
\hline Australia - NWS & 45.32 & 47.81 \\
\hline Australia - Darwin & 44.39 & 46.83 \\
\hline Algeria - Skikda & 42.3 & 44.63 \\
\hline Algeria - Bethioua & 43.22 & 45.60 \\
\hline Algeria - Arzew & 43.48 & 45.87 \\
\hline Brunei & 44.68 & 47.14 \\
\hline Egypt - Idku & 41.76 & 44.06 \\
\hline Egypt - Damietta & 40.87 & 43.12 \\
\hline Equatorial Guinea & 41.95 & 44.26 \\
\hline Indonesia - Arun & 43.29 & 45.67 \\
\hline Indonesia - Badak & 44.63 & 47.08 \\
\hline Indonesia - Tangguh & 41 & 43.26 \\
\hline Libya & 46.24 & 48.78 \\
\hline Malaysia & 43.67 & 46.07 \\
\hline Nigeria & 43.41 & 45.80 \\
\hline Norway & 42.69 & 45.04 \\
\hline Oman & 43.99 & 46.41 \\
\hline Peru & 42.9 & 45.26 \\
\hline Qatar & 43.43 & 45.82 \\
\hline Russia - Sakhalin & 43.3 & 45.68 \\
\hline Trinidad and Tobago & 41.05 & 43.31 \\
\hline U.S. - Alaska & 39.91 & 42.11 \\
\hline Yemen & 42.29 & 44.62 \\
\hline Average & 43.03 & 45.40 \\
\hline
\end{tabular}

Note: (n): Normal cubic metre: calorific values calculated at $0^{\circ} \mathrm{C}$ and 1.01325 bar of atmosphere. (s): standard cubic metre: calorific values calculated at $15^{\circ} \mathrm{C}$ and 1.01325 bar of atmosphere. See Appendix D for conversion rates. 


\section{APPENDIX C: PROPOSED LNG EXPORT FACILITIES IN BRITISH COLUMBIA AND THE NORTHWEST UNITED STATES}

\begin{tabular}{|c|c|c|c|c|c|c|}
\hline Location & Asset Name & Ownership & $\begin{array}{l}\text { Capacity } \\
\text { (MTPA) }\end{array}$ & $\begin{array}{l}\text { NEB Export } \\
\text { Application } \\
\text { Status and } \\
\text { Length }\end{array}$ & $\begin{array}{c}\text { NEB Maximum } \\
\text { Annual Export } \\
\text { Allowance } \\
\text { (MTPA) }\end{array}$ & $\begin{array}{l}\text { Expected } \\
\text { Start Date }\end{array}$ \\
\hline Kitimat, B.C. & $\begin{array}{l}\text { Douglas } \\
\text { Channel } \\
\text { Energy Project }\end{array}$ & $\begin{array}{l}\text { Haisla Nation/LNG } \\
\text { Partners (50\%), Golar } \\
\text { LNG (25\%), Unnamed } \\
\text { Asian Investor (25\%) (10) }\end{array}$ & $1.8(10)$ & $\begin{array}{l}\text { Approved; } 20 \\
\text { years }\end{array}$ & $1.98(2)$ & $2015(29)$ \\
\hline Kitimat, B.C. & $\begin{array}{l}\text { Kitimat LNG } \\
\text { Terminal }\end{array}$ & $\begin{array}{l}\text { Apache Canada Ltd. } \\
(50 \%) \text {, Chevron Corp. } \\
(50 \%)(8)\end{array}$ & $5(17)$ & $\begin{array}{l}\text { Approved; } 20 \\
\text { years }\end{array}$ & $11(1)$ & $2017(31)$ \\
\hline Kitsault, B.C. & Kitsault & $\begin{array}{l}\text { Kitsault Energy, and a } \\
\text { signed Memorandum of } \\
\text { Understanding "with an } \\
\text { Asian Oil and Gas Major" } \\
\text { (18) }\end{array}$ & $5(18)$ & $\begin{array}{l}\text { Under review; } \\
25 \text { years }\end{array}$ & & 2017 (18) \\
\hline Woodfibre, B.C. & Woodfibre LNG & $\begin{array}{l}\text { Woodfibre (Pacific Oil \& } \\
\text { Gas Group) }\end{array}$ & $2.1(23)$ & $\begin{array}{l}\text { Approved; } 25 \\
\text { years }\end{array}$ & $2.53(7)$ & $2017(23)$ \\
\hline $\begin{array}{l}\text { Kitimat or Prince } \\
\text { Rupert, B.C. (19) }\end{array}$ & Triton LNG & $\begin{array}{l}\text { AltaGas Ltd. (50\%), } \\
\text { Idemitsu Kosan Co. } \\
(50 \%)(11)\end{array}$ & $2.3(19)$ & $\begin{array}{l}\text { Approved; } 25 \\
\text { years }\end{array}$ & 2.645 (37) & 2017 (19) \\
\hline $\begin{array}{l}\text { Lelu Island, Port } \\
\text { Edward, B.C. }\end{array}$ & $\begin{array}{l}\text { Pacific } \\
\text { Northwest LNG }\end{array}$ & $\begin{array}{l}\text { Petronas (62\%), SINOPEC } \\
\text { (15\%), Indian Oil Corp. } \\
\text { (10\%), Japex (10\%), } \\
\text { Petroleum Brunei (3\%) } \\
\text { (14) }\end{array}$ & $12(22)$ & $\begin{array}{l}\text { Approved; } 25 \\
\text { years }\end{array}$ & $24.13(6)$ & $2018(22)$ \\
\hline Coos Bay, Ore. & $\begin{array}{l}\text { Jordan Cove } \\
\text { LNG }\end{array}$ & Versen Inc. (16) & $6(24)$ & $\begin{array}{l}\text { Approved; } 25 \\
\text { years }\end{array}$ & $13.63(36)$ & $2018(25)$ \\
\hline Astoria, Ore. & Oregon LNG & Oregon LNG & $9.74(26)$ & $\begin{array}{l}\begin{array}{l}\text { Approved; } 25 \\
\text { years }\end{array}\end{array}$ & $11.20(38)$ & $2019(27)$ \\
\hline $\begin{array}{l}\text { Campbell River, } \\
\text { B.C. }\end{array}$ & Discovery LNG & $\begin{array}{l}\text { Quicksilver Resources } \\
\text { Canada, and a "to be } \\
\text { determined third party" } \\
\text { (15) }\end{array}$ & & None & & $2019(30)$ \\
\hline Kitimat, B.C. & $\begin{array}{l}\text { LNG Canada } \\
\text { Terminal }\end{array}$ & $\begin{array}{l}\text { Shell Canada Ltd. (40\%), } \\
\text { Mitsubishi Corp. }(20 \%), \\
\text { Korea Gas Corp. }(20 \%), \\
\text { PetroChina }(20 \%)(9)\end{array}$ & $12(9)$ & $\begin{array}{l}\text { Approved; } 25 \\
\text { years }\end{array}$ & 27.6 (4) & $2020(28)$ \\
\hline $\begin{array}{l}\text { Kitimat or Prince } \\
\text { Rupert, B.C. (32) }\end{array}$ & WCC LNG & $\begin{array}{l}\text { Imperial Oil Ltd. (50\%), } \\
\text { ExxonMobil Canada } \\
(50 \%)(12)\end{array}$ & $10-15(12)$ & $\begin{array}{l}\text { Approved; } 25 \\
\text { years }\end{array}$ & $35.23(3)$ & $\begin{array}{l}2021-2022 \\
(12)\end{array}$ \\
\hline $\begin{array}{l}\text { Ridley Island, } \\
\text { Prince Rupert, B.C. }\end{array}$ & $\begin{array}{l}\text { Prince Rupert } \\
\text { LNG }\end{array}$ & BG Group & $14(20)$ & $\begin{array}{l}\text { Approved; } 25 \\
\text { years }\end{array}$ & $25.6(5)$ & 2021 (21) \\
\hline Grassy Point, B.C. & Aurora LNG & $\begin{array}{l}\text { Nexen (60\%), Inpex Corp. } \\
\text { \& JGC Corp. (40\%) (13) }\end{array}$ & 24 (39) & $\begin{array}{l}\text { Approved; } 25 \\
\text { years }\end{array}$ & $27.6(39)$ & $\begin{array}{l}2021-2023 \\
(13)\end{array}$ \\
\hline Stewart, B.C. & $\begin{array}{l}\text { Stewart Energy } \\
\text { LNG }\end{array}$ & $\begin{array}{l}\text { Canada Stewart Energy } \\
\text { Group Ltd. (34) }\end{array}$ & $5-30(34)$ & $\begin{array}{l}\text { Under review; } \\
25 \text { years (33) }\end{array}$ & & 2017 (34) \\
\hline Grassy Point, B.C. & TBA & Woodside Petroleum (35) & & None & & \\
\hline $\begin{array}{l}\text { Vancouver, B.C. } \\
\text { (42) }\end{array}$ & Tilbury LNG & $\begin{array}{l}\text { WesPac Midstream- } \\
\text { Vancouver LLC }\end{array}$ & $3(41)$ & $\begin{array}{l}\text { Under review; } \\
25 \text { years (40) }\end{array}$ & $3.5(41)$ & $2016(41)$ \\
\hline
\end{tabular}




\section{NEB Export Allowance Sources:}

(1) Source: National Energy Board, "Reasons for Decision, KM LNG Operating General Partnership, GH-1-2011," October 2011, 33, Appendix II, https://docs.neb-one.gc.ca/lleng/llisapi.dll/fetch/2000/90466/94153/552726/657379/657474/735753/728336/A2F3D2_ -_RfD_GH-1-2011_KM_LNG.pdf?nodeid=728337\&vernum=-2.

(2) Source: National Energy Board, "Reasons for Decision, BC LNG Export Co-operative LLC, GH-003-2011,” February 2012, 20, Appendix II, https://docs.neb-one.gc.ca/lleng/llisapi.dll/fetch/2000/90466/94153/552726/674445/674203/787318/787451/A2L8I2__BC_LNG_Export_Co-operative_LLC-_GH-003-

2011_Reasons_for_Decision.pdf?nodeid=787452\&vernum=-2.

(3) Source: National Energy Board, "Letter Decision, File OF-EI-Gas-GL-W156-2013-01 01,” December 16, 2013, 9, Appendix I, https://docs.neb-one.gc.ca/lleng/llisapi.dll/fetch/2000/90466/94153/552726/963926/977286/2392685/Letter_Decision_ WCC_LNG_Ltd._-_A3S0X4.pdf?nodeid=2393161\&vernum=-2. Conversion from 47.61 $109 \mathrm{~m} 3 / \mathrm{y}$ to $35.23 \mathrm{MTPA}$ using $1109 \mathrm{~m} 3=0.74 \mathrm{mt}$ LNG (BP Conversion Factors).

(4) Source: National Energy Board, "Letter Decision, File OF-EI-Gas-GL-L384-2012-01 01," February 4, 2013, 12, Appendix I, https://docs.neb-one.gc.ca/lleng/llisapi.dll/fetch/2000/90466/94153/552726/834773/834774/915307/A3F2D6__LNG_Canada_Development_Inc._Application_for_a_Licence_to_Export_Liquefied_Nat ural_Gas_-

_National_Energy_Board_Reasons_for_Decision.pdf?nodeid=915693\&vernum=-2.

(5) Source: National Energy Board, "Letter Decision, File OF-EI-Gas-GL-P756-2013-01 01," December 16, 2013, 8, Appendix I, https://docs.neb-one.gc.ca/lleng/llisapi.dll/fetch/2000/90466/94153/552726/963869/977381/2385390/Letter_Decision_ Prince_Rupert_LNG_Exports_Limited_-_A3SOX1.pdf?nodeid=2385281\&vernum $=-2$. Conversion from $34.60109 \mathrm{~m} 3 / \mathrm{y}$ to $25.6 \mathrm{MTPA}$ using $1109 \mathrm{~m} 3=0.74 \mathrm{mt}$ LNG (BP Conversion Factors).

(6) Source: National Energy Board, "Letter Decision, File OF-EI-Gas-GL-P757-2013-01 01," December 16, 2013, 8, Appendix I, https://docs.neb-one.gc.ca/lleng/llisapi.dll/fetch/2000/90466/94153/552726/971020/971021/2385392/Letter_Decision_ Pacific_NorthWest_LNG_Ltd._-_A3S0X9.pdf?nodeid=2385393\&vernum=-2. Conversion from $32.61109 \mathrm{~m} 3 / \mathrm{y}$ to $24.13 \mathrm{MTPA}$ using $1109 \mathrm{~m} 3=0.74 \mathrm{mt}$ LNG (BP Conversion Factors).

(7) Source: National Energy Board, "Letter Decision, File OF-EI-Gas-GL-W157-2013-01 01,” December 16, 2013, 7, Appendix I, https://docs.neb-one.gc.ca/lleng/llisapi.dll/fetch/2000/90466/94153/552726/977416/977417/2385283/Letter_Decision_ Woodfibre_LNG_Export_Pte._Ltd._-_A3S0Y4.pdf?nodeid=2385061\&vernum=-2 . Conversion from $3.42109 \mathrm{~m} 3 / \mathrm{y}$ to $2.53 \mathrm{MTPA}$ using $1109 \mathrm{~m} 3=0.74 \mathrm{mt}$ LNG (BP Conversion Factors).

(33) Source: National Energy Board, "Incomplete Application, File OF-EI-Gas-GL-C9642014-01 01." 
(36) Source: National Energy Board, "Letter Decision, File OF-EI-Gas-GL-J705-2013-01 01," December 16, 2013, 11, Appendix I, https://docs.neb-one.gc.ca/l1eng/llisapi.dll/fetch/2000/90466/94153/552726/977416/977417/2385283/Letter_Decision_ Woodfibre_LNG_Export_Pte._Ltd._-_A3S0Y4.pdf?nodeid=2385061\&vernum=-2 . Conversion from $18.43109 \mathrm{~m} 3 / \mathrm{y}$ to $2.53 \mathrm{MTPA}$ using $1109 \mathrm{~m} 3=0.74 \mathrm{mt}$ LNG (BP Conversion Factors).

(37) Source: National Energy Board, "Letter Decision File OF-EI-Gas_GL-T293-2013-01-01," April 16, 2014, https://docs.neb-one.gc.ca/lleng/llisapi.dll/fetch/2000/90466/94153/552726/1057161/1057402/2450590/Letter_Decisio n_to_Triton_LNG_Limited_Partnership_re_application_dated_29_October_2013_for_a_li cence_to_export_Liquefied_Natural_Gas_-_A3V9C2.pdf?nodeid=2450792\&vernum=-2 .

(38) Source: National Energy Board, "Letter Decision, File OF-EI-Gas-GI-O113-2014-01 01," May 1, 2014, https://docs.neb-one.gc.ca/lleng/llisapi.dll/fetch/2000/90466/94153/552726/2397958/2397738/2452611/Letter_Decision__Oregon_LNG_Marketing_Company_LLC_-_A3W3R6.pdf?nodeid=2452176\&vernum=-2.

(39) Source: National Energy Board, "Letter Decision, File OF-EI-Gas-GL-A777-2013-01 01," May 1, 2014, https://docs.neb-one.gc.ca/lleng/llisapi.dll/fetch/2000/90466/94153/552726/2381180/2381500/2452793/Letter_Decisio n_-_Aurora_LNG_Ltd._-_A3W3R3.pdf?nodeid=2452698\&vernum=-2.

(40) Source: National Energy Board website, "LNG Export License Applications," http://www.neb-one.gc.ca/clfnsi/rthnb/pplctnsbfrthnb/lngxprtlcncpplctns/lngxprtlcncpplctns-eng.html

\section{Ownership Sources:}

(8) Source: Kitimat LNG Facility Website, "Ownership," http://www.kitimatlngfacility.com/Project/project_ownership.aspx.

(9) Source: Shell, "Shell and partners announce LNG project in Canada," News Release, May 15, 2012, http://www.shell.com/global/aboutshell/media/news-and-mediareleases/2012/lng-canada-15052012.html.

(10) Source: Gordon Hamilton, "Golar LNG joins Douglas Channel liquefied natural gas project," Vancouver Sun, May 30, 2013, http://www.vancouversun.com/Golar+joins+Douglas+Channel+liquefied+natural+project/ 8456519/story.html.

(11) Source: Triton LNG Limited Partnership via National Energy Board, "Application of Triton LNG Limited Partnership,” October 29, 2013, 3, https://docs.neb-one.gc.ca/lleng/llisapi.dll/fetch/2000/90466/94153/552726/1057161/1057402/1057148/A3Q3C5__Application_for_Licence_to_Export_Natural_Gas.pdf?nodeid=1057149\&vernum $=-2$.

(12) Source: Warren True, "ExxonMobil affiliates plan Canadian LNG export," Oil and Gas Journal, July 10, 2013, http://www.ogj.com/articles/2013/07/exxonmobil-affiliates-plancanadian-lng-export.html. 
(13) Source: Bret Jang, "CNOOC heads group seeking to export liquefied natural gas," The Globe and Mail, November 29, 2013, http://www.theglobeandmail.com/report-onbusiness/industry-news/energy-and-resources/cnooc-heads-group-seeking-to-export-bcliquefied-natural-gas/article15687702/.

(14) Source: Canadian Newsire, "Progress Energy Canada and Pacific NorthWest LNG welcome fourth buyer to British Columbia LNG export project," April 29, 2014, http://www.newswire.ca/en/story/1345961/progress-energy-canada-and-pacific-northwestlng-welcome-fourth-buyer-to-british-columbia-lng-export-project.

(16) Source: Jordan Cove Energy Project Website, "About Us," http://www.jordancoveenergy.com/about.htm.

(35) Source: Bret Jang, "Australia's Woodside wins B.C. approval for LNG project," The Globe and Mail, January 16, 2014, http://www.theglobeandmail.com/report-onbusiness/industry-news/energy-and-resources/australias-woodside-wins-bc-approval-forlng-project/article16371320/.

\section{Capacity Sources:}

(17) Source: Kitimat LNG Facility Website, "Project Description," http://www.kitimatlngfacility.com/Project/project_description.aspx.

(18) Source: PRWeb.com, "Kitsault Energy has signed a Memorandum of Understanding (MOU) to partner with an Asian Oil and Gas Major," Kitsault Energy News Release, August 19, 2013, http://www.prweb.com/releases/2013/8/prweb11039379.htm.

(19) Source: Shaun Thomas, "Floating LNG export terminal proposed for the North Coast," The Northern View, October 31, 2013, http://www.thenorthernview.com/news/230061721.html.

(20) Source: Prince Rupert LNG Website, www.princerupertlng.ca.

(22) Source: Pacific NorthWest LNG, "Summary Sheet," 2. http://pacificnorthwestlng.com/wpcontent/uploads/2013/02/PNW_fs-Pacific-NorthWest-LNG-Feb-22.pdf.

(23) Source: Woodfibre LNG, "Project Overview," 2, http://www.woodfibrelngproject.ca/wpcontent/uploads/2013/11/LNGProjectOverview.pdf.

(24) Source: Jordan Cove Energy Project Website, "Project Overview," http://www.jordancoveenergy.com/project.htm.

(26) Source: Oregon LNG Website, "Terminal," http://www.oregonlng.com/terminal/. Calculated capacity: $(1.3 \mathrm{bcf} / \mathrm{d} * 365) / 48.7=9.74 \mathrm{MTPA}$.

(34) Source: Bret Jang, "Vancouver energy company applies for LNG export license," The Globe and Mail, March 5, 2014, http://www.theglobeandmail.com/report-onbusiness/industry-news/energy-and-resources/vancouver-energy-company-applies-for-lngexport-licence/article17337247/. Note: The initial 2017 capacity of 5mtpa is achieved using a floating liquefaction unit. The possibility of total plant capacity of $30 \mathrm{mtpa}$ is based on a land-based facility to be constructed in the future. 
(41) Source: National Energy Board website, "Application of WesPac Midstream - Vancouver LLC," https://docs.neb-one.gc.ca/lleng/llisapi.dll/fetch/2000/90466/94153/552726/2482343/2482959/2483502/Application_f or_Licence_to_Export_Natural_Gas_-_A3Y4Q6.pdf?nodeid=2483305\&vernum=-2.

\section{Expected Start Date Sources:}

(21) Source: AECOM, "Summary of Project Description: Prince Rupert LNG," 9, http://www.ceaa-acee.gc.ca/050/documents/p80042/88546E.pdf.

(25) Source: ECONorthwest, "Effect of the Jordan Cove Energy Project's LNG Exports on United States Balance of Trade 2018 - 2045," 1, http://www.jordancoveenergy.com/pdf/Trade_Balance.pdf.

(27) Source: Oregon LNG Website, http://www.oregonlng.com/.

(28) Source: Kitimat City Website, "Major Projects," http://www.kitimat.ca/EN/main/business/invest-in-kitimat/major-projects.html.

(29) Source: Invest in Northwest British Columbia Website, "Douglas Channel Energy Partnership," http://investnorthwestbc.ca/major-projects-and-investmentopportunities/map-view/kitimat/douglas-channel-energy-project-2.

(30) Source: Discovery LNG Website, http://www.discoverylng.com/.

(31) Source: The Globe and Mail, "China's Sinopec in talks to invest in Kitimat LNG project in B.C.:Source," November 27, 2013, http://www.theglobeandmail.com/report-onbusiness/industry-news/energy-and-resources/sinopec-in-talks-to-invest-in-kitimat-lngproject-in-bc-source/article15625726/.

\section{Location Sources:}

(32) Source: National Energy Board, "Letter Decision, File OF-EI-Gas-GL-W156-2013-01 01," December 16, 2013, 2, https://docs.neb-one.gc.ca/lleng/llisapi.dll/fetch/2000/90466/94153/552726/963926/977286/2392685/Letter_Decision_ WCC_LNG_Ltd._-_A3S0X4.pdf?nodeid=2393161\&vernum=-2.

(42) Source: WesPac Midstream website, "NEB Application to Export LNG from Canada," http://wespac.com/business/irvine-ca-june-24-2014-wespac-midstream-vancouver-llcwpmv-a-subsidiary-of-wespac-midstream-llc-wespac-has-submitted-an-application. 


\section{APPENDIX D: DEFINITIONS AND GLOSSARY}

\section{Definitions}

\begin{tabular}{l} 
Term \\
\hline British thermal unit (BTU) \\
$\begin{array}{l}\text { Conventional oil and gas } \\
\text { production }\end{array}$
\end{tabular}

Joule (J)

Liquefied
natural gas (LNG)

Liquefied

petroleum gas (LPG)

Natural gas liquid (NGL)

Normal cubic metre (NCM)

Sales and purchase agreement (SPA)

Standard cubic metre (SCM)

Unconventional oil and gas production ${ }^{2}$

\section{Definition}

A unit of energy equal to about 1,055 joules. It is the amount of energy needed to cool or heat $1 \mathrm{lb}$. of water by one degree Fahrenheit.

Crude oil and natural gas that is produced by a well drilled into a geologic formation in which the reservoir and fluid characteristics permit the oil and natural gas to readily flow to the wellbore. That is, geopressure is sufficient for fluid to flow to the surface.

The metre-kilogram-second unit of work or energy, equal to the work done by a force of one newton when its point of application moves through a distance of one metre in the direction of the force; equivalent to 107 ergs and one watt-second.

LNG is natural gas (predominantly methane) that is converted to liquid form via cooling to $-162^{\circ} \mathrm{C}$.

LPG is a flammable mix of hydrocarbon gases, usually containing primarily propane or butane.

NGLs comprise the light ends (ethane, propane, butanes) of the hydrocarbon family.

Volume measured at $0^{\circ} \mathrm{C}$ and a pressure of $760 \mathrm{mmHg}$, or 1.01325 bar of atmosphere.

A long-term (15-30 year) contract between LNG buyers and sellers.

Volume measured at $15^{\circ} \mathrm{C}$ and a pressure of $760 \mathrm{mmHg}$, or 1.01325 bar of atmosphere.

An umbrella term for oil and natural gas that is produced by means that do not meet the criteria for conventional production. Note: What has qualified as "unconventional" at any particular time is a complex interactive function of resource characteristics, the available exploration and production technologies, the current economic environment, and the scale, frequency, and duration of production from the resource. Perceptions of these factors inevitably change over time and they often differ among users of the term.

1 Quote of definition from: EIA, "Glossary,"

http://www.eia.gov/tools/glossary/index.cfm?id=C\#conv_oil_nat_gas_prod.

2 Quote of definition from: EIA, "Glossary," http://www.eia.gov/tools/glossary/index.cfm?id=U\#. 


\section{Abbreviations}

BP

CAPP

EIA

GIIGNL

IEA

IGU

NEB
British Petroleum

Canadian Association of Petroleum Producers

U.S. Energy Information Administration

International Group of Liquefied Natural Gas Importers

International Energy Agency

International Gas Union

National Energy Board of Canada

\section{Units}

\begin{tabular}{lll} 
Abbreviation & Unit & Use \\
\hline T & Tonne(s) & Mass \\
MMT & Million tonnes & Mass \\
TPA & Tonnes per annum & Capacity \\
MMTPA & Million tonnes per annum & Capacity \\
MMCM & Million cubic metres & \\
BCM & Billion cubic metres & Volume \\
TCM & Trillion cubic metres & Volume \\
MMCF & Million cubic feet & Volume \\
BCF & Billion cubic feet & Volume \\
TCF & Trillion cubic feet & Volume \\
J & & Volume \\
GJ & Joule & Energy content \\
PJ & Gigajoule & Energy content \\
BTU & Petajoule & Energy content \\
\hline MMTU & Million British thermal units & Energy content \\
\hline
\end{tabular}




\section{Conversions}

Source for conversions: IEA, Natural Gas Information 2013 (2013).

\section{GENERAL CONVERSION FACTORS FOR ENERGY}

\begin{tabular}{llllll} 
To: & TJ & Gcal & Mtoe & MBtu & GWh \\
\hline From: & Multiply by: & & & & \\
\hline TJ & 1 & 238.8 & $2.388 \times 10 \mathrm{e}-5$ & 947.8 & 0.2778 \\
Gcal & $4.1868 \times 10 \mathrm{e}-3$ & 1 & $10 \mathrm{e}-7$ & 3.968 & $1.163 \times 10 \mathrm{e}-3$ \\
Mtoe & $4.1868 \times 10 \mathrm{e} 4$ & $10 \mathrm{e} 7$ & 1 & $3.968 \times 10 \mathrm{e} 7$ & 11630 \\
MBtu & $1.0551 \times 10 \mathrm{e}-3$ & 0.252 & $2.52 \times 10 \mathrm{e}-7$ & 1 & $2.931 \times 10 \mathrm{e}-4$ \\
GWh & 3.6 & 860 & $8.6 \times 10 \mathrm{e}-5$ & 3412 & 1 \\
\hline
\end{tabular}

CONVERSION FACTORS FOR VOLUME

\begin{tabular}{lllllll} 
To: & U.S. gallon & U.K. gallon & Barrel & $\begin{array}{l}\text { Cubic } \\
\text { foot }\end{array}$ & Litre & $\begin{array}{l}\text { Cubic } \\
\text { metre }\end{array}$ \\
\hline From: & Multiply by: & & & & & \\
\hline U.S. gallon & 1 & 0.8327 & 0.02381 & 0.1337 & 3.785 & 0.0038 \\
U.K. gallon & 1.201 & 1 & 0.02859 & 0.1605 & 4.546 & 0.0045 \\
Barrel & 42.0 & 34.97 & 1 & 5.615 & 159.0 & 0.159 \\
Cubic foot & 7.48 & 6.229 & 0.1781 & 1 & 28.3 & 0.0283 \\
Litre & 0.2642 & 0.220 & 0.0063 & 0.0353 & 1 & 0.001 \\
Cubic metre & 264.2 & 220.0 & 6.289 & 35.3147 & 1000.0 & 1 \\
\hline
\end{tabular}


CONVERSION FACTORS FROM MASS OR VOLUME TO HEAT (GROSS CALORIFIC VALUE)

\begin{tabular}{|c|c|c|c|c|c|c|c|c|c|c|}
\hline \multirow[b]{3}{*}{ To: } & \multicolumn{2}{|c|}{ LNG** } & \multicolumn{8}{|c|}{ Gas } \\
\hline & & & \multicolumn{2}{|c|}{ Norway } & \multicolumn{2}{|c|}{ Netherlands } & \multicolumn{2}{|c|}{ Russia } & \multicolumn{2}{|c|}{ Algeria } \\
\hline & MJ & Btu & MJ & Btu & MJ & Btu & MJ & Btu & MJ & Btu \\
\hline From: & \multicolumn{10}{|c|}{ Multiply by: } \\
\hline $\mathbf{c m} *$ & 40.00 & 37,660 & 40.00 & 37,913 & 33.32 & 31,581 & 38.23 & 36,235 & 39.19 & 37,145 \\
\hline Kg & 54.25 & 51,417 & 52.22 & 49,495 & 42.07 & 39,875 & 55.25 & 52,363 & 52.46 & 49,726 \\
\hline
\end{tabular}

* at $15^{\circ} \mathrm{C}$.

** in gaseous state - average OECD imports.

\section{CONVERSION FACTORS FOR NATURAL GAS}

SCM versus NCM

From: Multiply by:

Standard cubic metre*

Normal cubic metre**

$* 1 \mathrm{Scm}$ measured at $15^{\circ} \mathrm{C}$ and $760 \mathrm{~mm} \mathrm{Hg}$.

**1 $\mathrm{Ncm}$ measured at $0^{\circ} \mathrm{C}$ and $760 \mathrm{~mm} \mathrm{Hg}$.

\section{LNG Versus Gas}

\begin{tabular}{llll} 
To: & Metric tonne LNG & CM of LNG & SCM* \\
\hline From: $\quad$ Multiply by: & & & \\
\hline Metric tonne LNG & 1 & 2.22 & 1,360 \\
CM LNG & 0.45 & 1 & 615 \\
SCM $^{*}$ & $7.35 \times 10 \mathrm{e}-4$ & $1.626 \times 10 \mathrm{e}-3$ & 1 \\
\hline
\end{tabular}

1

0.948

1.055

1

$* 1 \mathrm{SCM}=40 \mathrm{MJ}$ 
CONVERSION FACTORS FOR NATURAL GAS FLOW RATES ( *)

\begin{tabular}{|c|c|c|c|c|c|c|}
\hline To: & $\begin{array}{l}\text { BCM } \\
\text { per year }\end{array}$ & $\begin{array}{l}\text { Million } \\
\text { tonnes }\end{array}$ & $\begin{array}{l}\text { BCF } \\
\text { per day }\end{array}$ & $\begin{array}{l}\text { TCF } \\
\text { per year }\end{array}$ & $\begin{array}{l}\text { PJ } \\
\text { per year }\end{array}$ & $\begin{array}{l}\text { MMBTU } \\
\text { per year }\end{array}$ \\
\hline \multicolumn{7}{|l|}{ From: $\quad$ Multiply by: } \\
\hline BCM per year & 1 & 0.7350 & 0.09681 & 0.03534 & 40.00 & $3.79 \times 10 \mathrm{e} 7$ \\
\hline Million tonnes per year & 1.360 & 1 & 0.1317 & 0.04808 & 54.40 & $5.16 \times 10 \mathrm{e} 7$ \\
\hline BCF per day & 10.33 & 7.595 & 1 & 0.3650 & 413.2 & $3.91 \times 10 \mathrm{e} 8$ \\
\hline TCF per year & 28.30 & 20.81 & 2.740 & 1 & 1,132 & $1.07 \times 10 \mathrm{e} 9$ \\
\hline PJ per year & 0.02500 & 0.01838 & 0.002420 & $\begin{array}{l}8.834 x \\
10 e-4\end{array}$ & 1 & $9.47 \times 10 \mathrm{e} 5$ \\
\hline MMBTU per year & $\begin{array}{l}2.638 \mathrm{x} \\
10 \mathrm{e}-8\end{array}$ & $\begin{array}{l}1.939 x \\
10 e-8\end{array}$ & $\begin{array}{l}2.554 x \\
10 e-9\end{array}$ & $\begin{array}{l}9.32 \times \\
10 \mathrm{e}-10\end{array}$ & $\begin{array}{l}1.055 x \\
10 e-6\end{array}$ & 1 \\
\hline
\end{tabular}




\section{APPENDIX E: SOURCES FOR EXISTING AND PLANNED LIQUEFACTION TERMINALS}

\section{Algeria}

\section{A. OPERATIONAL}

Arzew GL 1Z: Year and capacity from International Group of Liquefied Natural Gas Importers, The LNG Industry in 2012 (Paris: GIIGNL, 2012).

Arzew GL 2Z: Year and capacity from International Group of Liquefied Natural Gas Importers, The LNG Industry.

Skikda Train 1-6: Year and capacity from Hydrocarbons Technology, "Sonatrach Skikda LNG Project, Algeria," http://www.hydrocarbons-technology.com/projects/sonatrach.

Skikda Rebuild: Year and capacity from International Gas Union, World LNG Report (2013), 49, http://www.igu.org/gas-knowhow/publications/igu-

publications/IGU_world_LNG_report_2013.pdf. Cost information from Hydrocarbons Technology, "Sonatrach Skikda."

\section{B. UNDER CONSTRUCTION}

Arzew GL 3Z: Year, capacity and construction status from International Gas Union, World LNG Report (2013), Appendix 2, http://www.igu.org/gas-knowhow/publications/igupublications/IGU_world_LNG_report_2013.pdf.

\section{Angola}

\section{A. OPERATIONAL}

Angola Soyo LNG Terminal: Year and capacity from Angola LNG Website, "About Us," http://www.angolalng.com/project/aboutLNG.htm. Cost from Benoit Faucon, "Chevron Confirms Angola LNG Plant To Cost \$9B," Downstream Today, December 24, 2009, http://downstreamtoday.com/news/article.aspx?a_id=20145\&AspxAutoDetectCookieSupport=1.

\section{Australia}

\section{A. OPERATIONAL}

Darwin LNG: Year and capacity from International Group of Liquefied Natural Gas Importers, The LNG Industry. Cost information from Hydrocarbons Technology, "Darwin LNG Project, Darwin Harbour, Australia," http://www.hydrocarbons-technology.com/projects/darwin/.

Pluto LNG: Year and capacity from International Group of Liquefied Natural Gas Importers, The LNG Industry. Cost information from Woodside, "Pluto Cost and Schedule Update," News Release, June 17, 2011, http://www.woodside.com.au/Investors-

Media/Announcements/Pages/Pluto-Cost-and-Schedule-Update.aspx.

Northwest Shelf Train 1-4: Year and capacity from Hydrocarbons Technology, "Northwest Shelf Venture, Australia," http://www.hydrocarbons-technology.com/projects/northwestshelf/.

Northwest Shelf Train 5: Year and capacity from Hydrocarbons Technology, "Northwest Shelf Venture." Cost information from Lloyd's List Daily Commercial News, "Woodside set to go ahead on fifth LNG train at Withnell Bay," January 10, 2005, http://www.lloydslistdcn.com.au/archive/2005/jan/10/woodside-set-to-go-ahead-on-fifth-lngtrain-at-withnell-bay. 


\section{B. UNDER CONSTRUCTION}

Queensland Curtis Train 1-2: Year and cost from QGC Website, "QCLNG Project," http://www.qgc.com.au/qclng-project.aspx. Capacity from QGC, "2013 QCLNG Project Fact Sheet," 2013, 1, http://www.qgc.com.au/media/100578/20121023_2013-qclng-project_fs.pdf. Construction status from International Gas Union, World LNG Report (2013), 49, http://www.igu.org/gas-knowhow/publications/igupublications/IGU_world_LNG_report_2013.pdf.

Australian Pacific: Year and cost from EPC Engineer, "Australia Pacific LNG Review Confirms Accelerated Schedule And Earlier Revenues - Costs Revised To \$24.7 Billion," February 21, 2013, http://www.epcengineer.com/news/post/9713/australia-pacific-lng-review-confirmsaccelerated-schedule-and-earlier-revenues-costs-revised-to-247. Capacity from Hydrocarbons Technology, "Queensland Pacific LNG Project, Gladstone, Queensland, Australia," http://www.hydrocarbons-technology.com/projects/australia-pacific-lng-queensland/. Construction status from International Gas Union, World LNG Report (2013), 49, http://www.igu.org/gas-knowhow/publications/igupublications/IGU_world_LNG_report_2013.pdf.

Fisherman's Landing Train 1: Year from PFC Energy, Global LNG Supply and Demand Study (May 2013), 49. Cost and capacity from James McGrath, "LNG project short of gas as big players snap up supply," The Observer, January 8, 2014, http://www.gladstoneobserver.com.au/news/project-short-of-gas-for-start-up/2133489/. Construction status from International Gas Union, World LNG Report (2013), 49, http://www.igu.org/gas-knowhow/publications/igupublications/IGU_world_LNG_report_2013.pdf.

Gladstone Santos: Year, capacity, and cost from the International Group of Liquefied Natural Gas Importers, The LNG Industry, 17. Construction status from International Gas Union, World LNG Report (2013), 49, http://www.igu.org/gas-knowhow/publications/igupublications/IGU_world_LNG_report_2013.pdf.

Gorgon Train 1-3: Year and capacity from International Gas Union, World LNG Report, Appendix 2. Cost from the International Group of Liquefied Natural Gas Importers, The LNG Industry, 17. Construction status from International Gas Union, World LNG Report (2013), 49, http://www.igu.org/gas-knowhow/publications/igupublications/IGU_world_LNG_report_2013.pdf.

Ichthys Train 1-2: Year, capacity, and cost from the International Group of Liquefied Natural Gas Importers, The LNG Industry, 17. Construction status from International Gas Union, World LNG Report (2013), 49, http://www.igu.org/gas-knowhow/publications/igupublications/IGU_world_LNG_report_2013.pdf.

Prelude FLNG: Year and capacity from the International Group of Liquefied Natural Gas Importers, The LNG Industry. Cost from Andrew Burrell, “\$12bn Prelude floating plant has Shell fired for LNG," The Australian, May 21, 2011, http://www.theaustralian.com.au/news/bnprelude-floating-plant-has-shell-fired-for-lng/story-e6frg6n6-1226059923612. Construction status from International Gas Union, World LNG Report (2013), 49, http://www.igu.org/gasknowhow/publications/igu-publications/IGU_world_LNG_report_2013.pdf.

Wheatstone LNG Train 1-2: Year, capacity, and cost from Reuters, "UPDATE 1-Chevron targets Australia LNG expansion despite cost pressure," May 27, 2013, http://www.reuters.com/article/2013/05/28/chevron-australia-idUSL3N0E90GT20130528. Construction status from International Gas Union, World LNG Report (2013), 49, http://www.igu.org/gas-knowhow/publications/igupublications/IGU_world_LNG_report_2013.pdf. 


\section{PROPOSED/ANNOUNCED}

Arrow T1-T2: Year from PFC Energy, Global LNG Supply, May 2013, 49. Capacity from Arrow Energy Website, “Arrow LNG Plant,” March 28, 2014, http://www.arrowenergy.com.au/projects/arrow-lng-plant. Cost from Ben Creagh, "Arrow LNG Project moves forward with environmental approval," Rigzone, September 11, 2013, http://www.rigzone.com/news/oil_gas/a/128973/Arrow_LNG_Project_Moves_Forward_with_E nvironmental_Approval.

Bonaparte FLNG: Year and capacity from Christine Forster, "Australia's Bonaparte floating LNG project to start up in 2019," Platts, September 11, 2013, http://www.platts.com/latestnews/natural-gas/darwin-australia/australias-bonaparte-floating-lng-project-to-27399343. Cost from Marc Castro, "GDF Suez and Santos May Seek New Partner for Bonaparte LNG," Venture Capital Post, May 1, 2013, http://www.vcpost.com/articles/8253/20130501/gdf-suezsantos-seek-new-partner-bonaparte-lng.htm.

Cash Maple LNG: Year from PTTEP Australasia website, "Proposed Projects," http://www.au.pttep.com/projects/proposed.

Fisherman's Landing Train 2: Cost and capacity from LNG Ltd website, "Australia," http://www.lnglimited.com.au/irm/content/australia1 .aspx?RID=262\&RedirectCount=1 .

Scarborough FLNG: Year, capacity, and cost from Rebekah Kebede, "Exxon, BHP plan world's largest floating LNG plant off Australia," Reuters, April 2, 2013, http://www.reuters.com/article/2013/04/02/us-exxon-bhp-lng-idUSBRE9310C920130402.

Sunrise - Timor Leste: Year and capacity from PFC Energy, Global LNG Supply, May 2013, 51. Cost from International Business Times, "Woodside Petroleum firm on floating LNG for East Timor Sunrise proj," June 4, 2010, http://au.ibtimes.com/articles/26734/20100604/woodsidepetroleum-floating-lng-greater-sunrise-gas-field-east-timor-xanana-gusmao-donvoelte.htm\#.U2zz_61dWuq.

\section{Brunei}

\section{A. OPERATIONAL}

Lumut: Year and capacity from International Group of Liquefied Natural Gas Importers, The LNG Industry.

\section{Cameroon}

\section{A. PROPOSED/ANNOUNCED}

Cameroon LNG: Capacity from Cameron LNG website, "Cameroon LNG Project," http://www.cameroonlngproject.com/documents/cameroon-lng-project-en.pdf. 


\section{Canada (excluding those described in Appendix C)}

\section{A. PROPOSED/ANNOUNCED}

Canaport LNG: Capacity from Ashok Dutta, "Canada's Canaport LNG import terminal keeps reexport option open," Platts, November 29, 2013, http://www.platts.com/latest-news/naturalgas/calgary/canadas-canaport-lng-import-terminal-keeps-re-27681324. Cost from Esteban Duarte and Rebecca Penty, "Repsol eyes US\$2B LNG export plant at Canaport site in New Brunswick," National Post, May 20, 2014, http://business.financialpost.com/2014/05/20/repsol-eyes-us2b-lng-export-plant-at-canaportsite-in-new-brunswick/?_lsa=f044-2735.

Goldboro LNG: Year, capacity and cost from Goldboro LNG website, "Project Overview," http://goldborolng.com/project/project-overview/.

\section{Colombia}

\section{A. UNDER CONSTRUCTION}

Exmar LNG FLNG: Year, capacity, and cost from Gurdip Singh, "EXMAR launches FLRSU to exploit stranded gas offshore Colombia," Offshore Magazine, August 1, 2012, http://www.offshore-mag.com/articles/print/volume-72/issue-8/engineering-constructioninstallation1/exmar-launches-flrsu-to-exploit-stranded-gas-offshore-colombia.html. Construction status from International Group of Liquefied Natural Gas Importers, The LNG Industry, 17.

\section{B. PROPOSED/ANNOUNCED}

Pacific Rubiales: Year and capacity from International Gas Union, World LNG Report (2013), 49, http://www.igu.org/gas-knowhow/publications/igupublications/IGU_world_LNG_report_2013.pdf.

\section{Cyprus}

\section{A. PROPOSED/ANNOUNCED}

Cyprus LNG: Year and cost from Karen Ayat, "Total, Noble, Delek and Avner Interested in Participating in Cyprus' LNG," Natural Gas Europe, June 28, 2013, http://www.naturalgaseurope.com/total-noble-delek-and-avner-interested-in-participating-incyprus-lng. Capacity from Ministry of Energy, Commerce, Industry, and Tourism, "Vasilikos Energy Centre,"

http://www.mcit.gov.cy/mcit/mcit.nsf/b1d9808b11a79c45c2256e6600488e3a/02b6e904de1dc82 2c2257b2100257b20?OpenDocument.

\section{Egypt}

\section{A. OPERATIONAL}

Damietta: Year and capacity from International Group of Liquefied Natural Gas Importers, The LNG Industry. Cost from Hydrocarbons Technology, "SEGAS Liquefied Natural Gas Complex, Damietta, Egypt," http://www.hydrocarbons-technology.com/projects/seagas/.

Idku Train 1-2: Year, capacity, and cost from Arab Republic of Egypt Ministry of Petroleum, "Egyption LNG Project in Idku," http://www.petroleum.gov.eg/en/ProjectsandActivities/StrategicProjects/Pages/Idku.aspx. 


\section{B. PROPOSED/ANNOUNCED}

Damietta Train 2-3: Capacity from Hydrocarbons Technology, "SEGAS Liquefied Natural Gas Complex, Damietta, Egypt," http://www.hydrocarbons-technology.com/projects/seagas/.

\section{Equatorial Guinea}

\section{A. OPERATIONAL}

Bioko Island: Year and capacity from International Group of Liquefied Natural Gas Importers, The LNG Industry. Cost from Hydrocarbons Technology, "Equatorial Guinea LNG Project, Bioko Island, Punta Europa, Equatorial Guinea," http://www.hydrocarbonstechnology.com/projects/bioko-lng/.

\section{Indonesia}

\section{A. OPERATIONAL}

Tangguh: Year and capacity from International Group of Liquefied Natural Gas Importers, The LNG Industry. Cost from Bambang Djanuarto and Yoga Rusmana, "BP Shuts Indonesia's Tangguh LNG Plant Unit for Maintenance," Bloomberg, May 27, 2011, http://www.bloomberg.com/news/2011-05-27/bp-shuts-down-indonesia-s-tangguh-lng-plantunit-for-maintenance.html.

Blang Lancang - Arun Train 1-6, Expansion 1-2: Year and capacity from PT Arun NGL Website, "Our Profile," http://www.arunlng.co.id/profile.php.

Badak (Bontang) A-H: Year and capacity from Michael D. Tusiani and Gordon Shearer, LNG: A Nontechnical Guide, 286 (Tulsa, Ok.: PennWell, 2007).

\section{B. UNDER CONSTRUCTION}

Donggi Senoro: Year, capacity, and cost from Mitsubishi Corp., "Final Investment Decision on Donggi-Senoro LNG Project in Indonesia," News Release, January 24, 2011, http://www.mitsubishicorp.com/jp/en/pr/archive/2011/html/0000011637.html. Construction status from International Gas Union, World LNG Report (2013), 49, http://www.igu.org/gasknowhow/publications/igu-publications/IGU_world_LNG_report_2013.pdf.

SengKang LNG: Year and capacity from the International Group of Liquefied Natural Gas Importers, The LNG Industry, 18. Cost from Pak Alfian, "BPMigas rejects development plan for Sengkang LNG project," The Jakarta Post, January 29, 2010, http://www.thejakartapost.com/news/2010/01/29/bpmigas-rejects-development-plan-sengkanglng-project.html. Construction status from Proactive Investors website, "Energy World Corporation advances construction of LNG projects in Indonesia, Philippines," November 6, 2013, http://www.proactiveinvestors.com.au/companies/news/49877/energy-world-corporationadvances-construction-of-lng-projects-in-indonesia-philippines--49877.html.

\section{PROPOSED/ANNOUNCED}

Abadi FLNG: Year from London South East, "Inpex delays Indonesia Abadi LNG project startup to 2019 -media," June 25, 2013,

http://www.lse.co.uk/FinanceNews.asp?code=kvkqidfa\&headline=Inpex_delays_Indonesia_Ab adi_LNG_project_startup_to_2019_media. Capacity and cost from Subsea IQ Website, “Abadi," http://www.subseaiq.com/(X(1)S(elrpu2qai1w1dp55lwvwux55))/data/PrintProject.aspx?project _id=874\&_AspxAutoDetectCookieSupport=1. 
XII. Iran

\section{A. UNDER CONSTRUCTION}

Iran LNG: Capacity from Iran Liquefied Natural Gas Co. website, "Process Units Summary," http://www.iranlng.ir/en/our-project/process-units-summary. Cost and construction status Iran Liquefied Natural Gas Co. website, "Current Status," http://www.iranlng.ir/en/ourproject/current-status.

\section{B. PROPOSED/ANNOUNCED}

Pars LNG: Capacity from WorleyParsons website, "CNOOC North Pars LNG Project," http://www.worleyparsons.com/Projects/Pages/CNOOCNorth.aspx.

Persian LNG: Capacity from Iran LNG Center website, "Persian LNG," http://iranlngcenter.com/Persianlng.aspx.

\section{Israel}

\section{A. PROPOSED/ANNOUNCED}

Eilat LNG: Year, capacity, and cost from Amiram Barkat, "Gov’t cos want to build \$6b Eilat LNG facility," Globes, October 1, 2012, http://www.globes.co.il/en/article-1000714303.

Tamar FLNG: Capacity from Anna Shiryaevskaya, "Gazprom Seeks to Export All LNG From Israeli Tamar Project," Bloomberg, February 26, 2013, http://www.bloomberg.com/news/201302-26/gazprom-holds-talks-to-export-all-lng-from-israeli-tamar-project.html.

\section{Libya}

\section{A. OPERATIONAL}

Marsa-el-Brega: Year and capacity from International Group of Liquefied Natural Gas Importers, The LNG Industry.

\section{Malaysia}

\section{A. OPERATIONAL}

Bintulu MLNG 1 (Satu) Train 1-3: Year and capacity from International Group of Liquefied Natural Gas Importers, The LNG Industry.

Bintulu MLNG 2 (Dua) Train 1-3 and Debottleneck: Year and capacity from International Group of Liquefied Natural Gas Importers, The LNG Industry.

Bintulu MLNG 3 (Tiga) Train 1-2: Year and capacity from International Group of Liquefied Natural Gas Importers, The LNG Industry.

\section{B. UNDER CONSTRUCTION}

Bintulu MLNG Mini-expansion: Year, capacity and construction status from Construction status from International Gas Union, World LNG Report (2013), 49, http://www.igu.org/gasknowhow/publications/igu-publications/IGU_world_LNG_report_2013.pdf. 
Petronas FLNG 1: Year, Capacity, and cost from Nina Rach, "Petronas' Kanowit field FLNG facility under construction," OE Digital, August 19, 2013,

http://www.oedigital.com/component/k2/item/3760-petronas-kanowit-field-flng-facility-underconstruction. Construction status from International Gas Union, World LNG Report (2013), 49, http://www.igu.org/gas-knowhow/publications/igu-

publications/IGU_world_LNG_report_2013.pdf.

Petronas LNG 9: Year, capacity and construction status from International Gas Union, World LNG Report (2013), 49, http://www.igu.org/gas-knowhow/publications/igupublications/IGU_world_LNG_report_2013.pdf. Cost from 2 b 1st Consulting website, "Petronas to invest \$61 billion in Malaysia on next five years," March 13, 2013, http://www.2b1 stconsulting.com/petronas-to-invest-61-billion-in-malaysia-on-next-five-years/.

\section{PROPOSED/ANNOUNCED}

Petronas FLNG 2: Year and capacity from Florence Tan, "TABLE-Petronas to expand global LNG capacity by 2020," Reuters, June 14, 2013, http://uk.reuters.com/article/2013/06/14/malaysia-oil-gas-idUKL3NOEO09720130614.

\section{Mozambique}

\section{A. PROPOSED/ANNOUNCED}

Anadarko Eni: Year, capacity, and cost from Franz Wild, "Mozambique Seeks Bigger Stake in Anadarko, Eni Gas Fields,” Bloomberg, November 11, 2013, http://www.bloomberg.com/news/2013-11-11/mozambique-seeks-bigger-stake-in-anadarko-enigas-fields.html.

\section{Nigeria}

\section{A. OPERATIONAL}

Bonny Island NLNG Train 1-6: Year from Hydrocarbons Technology, "Bonny Island, Nigeria," http://www.hydrocarbons-technology.com/projects/bonny/. Capacity from ICIS, "Nigeria LNG Output climbs to $83 \%$ as Train 1 returns," http://www.icis.com/resources/news/2011/01/24/9428874/nigeria-lng-output-climbs-to-83-astrain-1-returns/ and Technip website, "Gas Monetization Key References," http://www.technip.com/sites/default/files/technip/field_activity/key_contracts_attachment/gas_ monetization_key_V2.pdf. Cost from Nigeria LNG Ltd., "Facts and Figures on NLNG 2013," 2013,37, http://www.nlng.com/publications/Facts_Figures_on_NLNG_2013.pdf.

\section{B. UNDER CONSTRUCTION}

Bonny Island NLNG Train 7: Capacity and construction status from Hydrocarbons Technology, "Bonny Island."

\section{PROPOSED/ANNOUNCED}

Bonny Island NLNG Train 8: Capacity from Hydrocarbons Technology, "Bonny Island."

Brass LNG: Year and capacity from PFC Energy, Global LNG Supply, 49. Cost from Martin Ayankola, "Brass LNG Project may cost over \$15BN," The Punch Newspaper, January 30, 2010, http://www.ijawmonitor.org/news.php?article=641\&ct=3. 
Olokola LNG: Capacity from Energy Mix Report website, "Planned LNG projects to generate \$15bn," April 1, 2014, http://energymixreport.com/planned-lng-projects-to-generate-15b/. Year from Energy Mix Report website, "OK LNG requires new investors," March 26, 2014, http://energymixreport.com/ok-lng-requires-new-investors/.

\section{Norway}

\section{A. OPERATIONAL}

Hammerfest: Year and capacity from International Group of Liquefied Natural Gas Importers, The LNG Industry. Cost information from Subsea IQ Website, "Snohvit," http://www.subseaiq.com/data/PrintProject.aspx?project_id=223.

Skangass: Year and cost from Hydrocarbons Technology, "Linde to build LNG import terminal for Skangass in Sweden," http://www.hydrocarbons-technology.com/news/newslinde-lngterminal-skangass. Capacity from Skangass AS, "About Skangass," http://www.skangass.com/index.cfm?id=352980.

\section{Oman}

\section{A. OPERATIONAL}

Qalhat/Oman LNG Train 1-2: Year from Chiyoda Corp. Website, "Oman," http://www.chiyodacorp.com/project/en/area/middle-east/oman.html. Capacity from Oman LNG Website, "In Brief," http://www.omanlng.com/tabid/158/Default.aspx. Cost from Hydrocarbons Technology, "Qalhat LNG Plant, Oman," http://www.hydrocarbons-technology.com/projects/qalhat/.

Qalhat/Oman LNG Train 3: Year, capacity, and cost from Qalhat LNG Website, "QLNG Project," http://www.qalhatlng.com/_Project.html\#_Project_PR.

\section{Papua New Guinea}

\section{A. UNDER CONSTRUCTION}

PNG LNG Train 1-2: Year, capacity, and cost from Jane Wardell and James Regan, "Exxon's PNG LNG project costs balloon to $\$ 19$ billion," Reuters, November 11, 2012, http://www.reuters.com/article/2012/11/12/us-exxon-png-idUSBRE8AA0GR20121112. Construction status from International Gas Union, World LNG Report (2013), 49, http://www.igu.org/gas-knowhow/publications/igupublications/IGU_world_LNG_report_2013.pdf.

\section{B. PROPOSED/ANNOUNCED}

Gulf LNG: Year, capacity, and cost from InterOil, "Economics and Financing of Gulf Integrated LNG Project," September 2012, 7 , http://www.interoil.com/iocfiles/documents/investorrelations/presentationanddocuments/2012/L NG\%20Project\%20Update\%20Investor\%20Presentation\%20September\%2029\%202012.pdf. 
XXI. Peru

\section{A. OPERATIONAL}

Peru LNG: Year and capacity from International Group of Liquefied Natural Gas Importers, The LNG Industry. Cost from PR Newswire, "PERU LNG Inaugurates the First Natural Gas Liquefaction (LNG) Plant in South America," Peru LNG News Release, June 10, 2010, http://www.prnewswire.com/news-releases/peru-lng-inaugurates-the-first-natural-gasliquefaction-lng-plant-in-south-america-96065044.html.

\section{Qatar}

\section{A. OPERATIONAL}

Ras Laffan (Qatargas 1 Train 1-3): Year from International Group of Liquefied Natural Gas Importers, The LNG Industry. Capacity from Qatargas Website, "Qatargas 1," http://www.qatargas.com/English/QGVentures/Pages/Qatargas1.aspx. Cost from Hydrocarbons Technology, "Qatar Gas I LNG Plant, Ras Laffan, Qatar," http://www.hydrocarbonstechnology.com/projects/raslaffanlng/.

Ras Laffan (Qatargas 1 Train 1-3) Debottleneck: Year and capacity from Qatargas Website, "Qatargas 1," http://www.qatargas.com/English/QGVentures/Pages/Qatargas1.aspx. Cost from Hydrocarbons Technology, "Qatar Gas I LNG Plant, Ras Laffan, Qatar," http://www.hydrocarbons-technology.com/projects/raslaffanlng/.

Ras Laffan (Qatargas 2 Train 1-2): Year and capacity from International Group of Liquefied Natural Gas Importers, The LNG Industry.

Ras Laffan (Qatargas 3 Train 1): Year and capacity from International Group of Liquefied Natural Gas Importers, The LNG Industry.

Ras Laffan (Qatargas 4 Train 1): Year and capacity from International Group of Liquefied Natural Gas Importers, The LNG Industry.

Ras Laffan (Rasgas 1 Train 1-2): Year and capacity from International Group of Liquefied Natural Gas Importers, The LNG Industry.

Ras Laffan (Rasgas 2 Train 1-3): Year and capacity from International Group of Liquefied Natural Gas Importers, The LNG Industry.

Ras Laffan (Rasgas 3 Train 1-2): Year and capacity from International Group of Liquefied Natural Gas Importers, The LNG Industry.

\section{Russia}

\section{A. OPERATIONAL}

Sakhalin 2: Year and capacity from International Group of Liquefied Natural Gas Importers, The $L N G$ Industry.

\section{B. PROPOSED/ANNOUNCED}

Russia Far East: Capacity from Rosneft website, "Rosneft and ExxonMobil Selects Contractors for Initial Phase Engineering and Design for Russian Far East LNG Project," news release, September 27, 2013, http://www.rosneft.com/news/pressrelease/27092013.html. 
Vladivostok: Year and capacity from Gazprom Website, "Vladivostok-LNG Project," http://www.gazprom.com/about/production/projects/vladivostok-lng/. Cost from Vladimir Soldatkin, "Gazprom's investment in Vladivostok LNG plant seen at \$13.5 bln," Reuters, November 21, 2013, http://www.reuters.com/article/2013/11/21/gazprom-lng-investmentidUSL5N0J60UD20131121.

Yamal: Year, cost, and capacity from Oil and Gas Journal, "Yamal LNG owners issue FID," December 18, 2013, http://www.ogj.com/articles/2013/12/yamal-lng-owners-issue-fid.html.

\section{Tanzania}

\section{A. PROPOSED/ANNOUNCED}

Tanzania LNG: Year and Capacity from Karolin Schaps, "UPDATE 1-Ophir Energy says Tanzania LNG project could be expanded," Reuters, March 20, 2014, http://www.reuters.com/article/2014/03/20/lng-tanzania-ophir-idUSL6N0MH1G620140320. Cost from Gwladys Fouche and Balazs Koranyi, "Statoil plans LNG plant after Tanzania gas find," The Globe and Mail, March 18, 2013, http://www.theglobeandmail.com/report-onbusiness/international-business/african-and-mideast-business/statoil-plans-lng-plant-aftertanzania-gas-find/article9881045/.

\section{Trinidad and Tobago}

\section{A. OPERATIONAL}

Atlantic LNG Train 1-4: Year and capacity from Atlantic LNG Website, "Our Trains," http://www.atlanticlng.com/our-business/our-trains. Cost from Hydrocarbons Technology, "Point Fortin Refinery / LNG Liquefaction Plant, Trinidad and Tobago," http://www.hydrocarbons-technology.com/projects/pointfortin/.

\section{United Arab Emirates}

\section{A. OPERATIONAL}

Das Island: Year and capacity from International Group of Liquefied Natural Gas Importers, The LNG Industry.

\section{XXVII.U.S.A}

\section{A. OPERATIONAL}

Kenai: Year and capacity from ConocoPhillips Website, "ConocoPhillips LNG Projects," http://lnglicensing.conocophillips.com/EN/lngprojects/Pages/index.aspx. Mothball year from Tim Bradner, "State asks ConocoPhillips to reopen idle Kenai LNG plant," Alaska Journal of Commerce, September 12, 2013, http://www.alaskajournal.com/Alaska-Journal-ofCommerce/September-Issue-3-2013/State-asks-ConocoPhillips-to-reopen-idle-Kenai-LNGplant/. Reactivation from ConocoPhillips website, "ConocoPhillips Announces Resumption of Exports from the Kenai LNG Facility," news release, April 14, 2014, http://alaska.conocophillips.com/newsroom/news-releases/Pages/Kenai-LNG-Plant-to-ResumeExports-This-Spring.aspx. 


\section{B. UNDER CONSTRUCTION}

Sabine Pass Train 1-4: Year, cost, capacity and construction status from Cheniere Website, "Sabine Pass Liquefication Project,"

http://www.cheniere.com/lng_industry/sabine_pass_liquefaction.shtml.

\section{PROPOSED/ANNOUNCED}

Alaska LNG: Year, capacity and cost from Bradley Olson and Rebecca Penty, "Alaska to Pay \$5.75 Billion for Exxon LNG Project Stake," Bloomberg, January 15, 2014, http://www.bloomberg.com/news/2014-01-15/alaska-to-pay-5-75-billion-for-exxon-lng-exportproject-stake.html.

Cameron LNG: Year, capacity, and cost from Cameron LNG Website, "Expansion Update," http://cameronlng.com/expansion-update.html.

Corpus Christi LNG: Year, capacity, and cost from Bechtel Website, "Bechtel enters into contract with Cheniere for Corpus Christi Liquefication Project," December 13, 2013, http://www.bechtel.com/2013-12-13.html.

Cove Point LNG: Year, cost, and capacity from Dominion Website, "Dominion Cove Point," https://www.dom.com/business/gas-transmission/cove-point/.

Elba Island LNG Phase 1 and 2: Year and capacity from International Gas Union, World LNG Report, 36. Cost from Siana Mishkova, "Shell share price: Shell, Kinder Morgan start \$500m expansion of US LNG project," Invezz, December 20, 2013, http://invezz.com/news/equities/7753-shell-share-price-shell-kinder-morgan-start-dollar-500mexpansion-of-us-lng-project.

Freeport Expansion: Cost and capacity from Freeport LNG Website, "Liquefication Project," http://www.freeportlng.com/Liquefaction_Project.asp. Year from Freeport LNG, "Project Status," http://www.freeportlng.com/Project_Status.asp.

Gasfin LNG: Year from U.S. Office of Fossil Energy, Natural Gas Regulatory Activities, "SemiAnnual Project Progress Report," April 1, 2014, http://www.fossil.energy.gov/programs/gasregulation/authorizations/semiannual_reports/Gasfin_-_Semi-Annual_Report_-_2014_Apr_1.pdf. Capacity from International Gas Union, World LNG Report, 36. Cost from Carla Bridglal, "Gasfin hoping to build US \$400m LNG plant at La Brea,” Trinidad Express Newspapers, February 12, 2013, http://www.trinidadexpress.com/businessmagazine/Gasfin_hoping_to_build_US_400m_LNG_plant_at_La_Brea-190948141.html

Golden Pass: Year and capacity from International Gas Union, World LNG Report, 36. Cost from Financial Post, "Qatar, Exxon venture wins first U.S. LNG export permit," October 4, 2012, http://business.financialpost.com/2012/10/04/qatar-exxon-venture-wins-first-u-s-lngexport-permit/?_lsa=f616-9532.

Gulf Coast LNG Train 1-4: Capacity from International Gas Union, World LNG Report, 36.

Jordan Cove - Coos Bay: Year from Econorthwest, "Effect of the Jordan Cove Energy Project's LNG Exports on United States Balance of Trade 2018 - 2045," February 28, 2012, 1, http://www.jordancoveenergy.com/pdf/Trade_Balance.pdf. Capacity from Jordan Cove Energy Project Website, "Project Overview," http://www.jordancoveenergy.com/project.htm. Cost from Jordan Cove Energy Project Website, "Project Benefits," http://www.jordancoveenergy.com/benefits.htm. 
Lake Charles Expansion: Year, capacity, and cost from Energy Transfer Partners LP, "Update to the Lake Charles Liquefication Project," News Release, August 8, 2013, http://ir.energytransfer.com/phoenix.zhtml?c=106094\&p=irol-newsArticle\&ID=1846291.

Magnolia LNG T1-T2: Year, capacity, and cost from Magnolia LNG Website, "Magnolia LNG Project on Schedule," September 12, 2013, http://www.magnolialng.com/IRM/Company/ShowPage.aspx ?CategoryId=190\&CPID=1949\& $\mathrm{EID}=68984696$.

Main Pass Energy Hub: Year, cost, and capacity from Ruth Liao, "US floating LNG concept files for regulatory approval," ICIS, September 21, 2012, http://www.icis.com/resources/news/2012/09/21/9597730/us-floating-lng-concept-files-forregulatory-approval/.

Oregon LNG Terminal: Year from Oregon LNG Website, "Project Timeline," http://www.oregonlng.com/project-timeline/. Capacity from Oregon LNG Website, "Terminal," http://www.oregonlng.com/terminal/. Cost from The Daily Astorian, "Oregon LNG files new plan with feds," June 12, 2013, http://www.dailyastorian.com/free/oregon-lng-files-new-planwith-feds/article_0e5a652a-d387-11e2-97b7-001a4bcf887a.html.

South Texas LNG Train 1-2: Year and capacity from International Gas Union, World LNG Report, 36.

Texas LNG: Year and capacity from Texas LNG website, "Texas LNG Summary," http://www.txlng.com/about/texas-lng-summary.

\section{Venezuela}

\section{A. PROPOSED/ANNOUNCED}

Mariscal Sucre: Capacity and cost from Business News Americas, "Chavez: Qatar will join US\$2.5bn Mariscal Sucre LNG project," June 10, 2002,

http://www.bnamericas.com/news/oilandgas/Chavez:_Qatar_will_join_US*2,5bn_Mariscal_Su cre_LNG_project. Current status from Enrique Andres Pretel and Marianna Parraga, "UPDATE 3-Venezuela freezes LNG projects, eyes local demand," Reuters, September 28, 2011, http://www.reuters.com/article/2011/09/28/venezuela-gas-idUSS1E78R0UG20110928.

\section{Yemen}

\section{A. OPERATIONAL}

Balhalf Train 1-2: Year and capacity from Technip, "Yemen LNG," http://www.technip.com/sites/default/files/technip/publications/attachments/YLNG_March\%20 2011_web.pdf. Cost from Yemen LNG Company Website, "Project Overview," http://www.yemenlng.com/ws/en/go.aspx?c=proj_overview. 


\section{APPENDIX F: SOURCES FOR EXISTING AND PLANNED REGASIFICATION TERMINALS}

\section{Albania}

\section{A. PROPOSED/ANNOUNCED}

Fiere FRSU: Year and capacity from the International Group of Liquefied Natural Gas Importers, "Database for QFlex-QMax Acceptability,"

http://www.giignl.org/system/files/publication/130819_giignl_qflex_qmax_database.xlsx.

\section{Argentina}

\section{A. OPERATIONAL}

Bahia Blanca: Year and capacity from the International Group of Liquefied Natural Gas Importers, The LNG Industry in 2012 (Paris: GIIGNL, 2012).

Escobar FRSU: Year and capacity from the International Group of Liquefied Natural Gas Importers, The LNG Industry in 2012.

\section{B. PROPOSED/ANNOUNCED}

Enarsa PDV: Year from the International Group of Liquefied Natural Gas Importers, "Database for QFlex-QMax Acceptability." Capacity from Hydrocarbons Technology, "Excelerate Energy to Develop Argentinian LNG Terminal," http://www.hydrocarbonstechnology.com/news/news96798.html.

\section{Bahamas}

\section{A. PROPOSED/ANNOUNCED}

Ocean Cay: Year and capacity from the International Group of Liquefied Natural Gas Importers, "Database for QFlex-QMax Acceptability." Cost from Downstream Today, "AES Ocean LNG," June 3, 2010, http://www.downstreamtoday.com/projects/project.aspx?project_id=59.

\section{Bangladesh}

\section{A. PROPOSED/ANNOUNCED}

Bangladesh FRSU: Capacity from Mohammad Azizur Rahman, "Bangladesh puts LNG terminal project on fast-track route," Platts, January 23 2014, http://www.platts.com/latest-news/naturalgas/dhaka/bangladesh-puts-lng-terminal-project-on-fast-27859956.

\section{Belgium}

\section{A. OPERATIONAL}

Zeebrugge: Year and capacity from the International Group of Liquefied Natural Gas Importers, The LNG Industry in 2012.

\section{B. PROPOSED/ANNOUNCED}

Zeebrugge Expansion: Year and capacity from the International Group of Liquefied Natural Gas Importers, "Database for QFlex-QMax Acceptability." 


\section{Brazil}

\section{A. OPERATIONAL}

Bahia Regas Terminal: Year, capacity, and cost from Gastech News, "Petrobras starts up Brazil's third FSRU import facility," January 29, 2014, http://www.gastechnews.com/lng/petrobrasstarts-up-brazils-third-fsru-import-facility/.

Guanabara Bay FRSU: Year and capacity from the International Group of Liquefied Natural Gas Importers, The LNG Industry in 2012.

Guanabara LNG FRSU: Year and cost from International Gas Union, World LNG Report, 52.

Pecem FRSU: Year and capacity from the International Group of Liquefied Natural Gas Importers, The LNG Industry in 2012.

\section{Canada}

\section{A. OPERATIONAL}

Canaport LNG: Cost and capacity from Hydrocarbons Technology, "Canaport LNG Plant, St John, New Brunswick, Canada," http://www.hydrocarbons-technology.com/projects/canaport-lng/.

\section{Chile}

\section{A. OPERATIONAL}

Mejilones: Year and capacity from the International Group of Liquefied Natural Gas Importers, The LNG Industry. Cost from Hydrocarbons Technology, "Mejillones Liquefied Natural Gas (LNG) Terminal, Chile," http://www.hydrocarbons-technology.com/projects/cnlmejillones/.

Quintero: Year and capacity from the International Group of Liquefied Natural Gas Importers, The LNG Industry. Cost from SeeNews, "BG Group mulls over selling half of $40 \%$ stake in GNL Quintero - report," February 24, 2012, http://energy.seenews.com/news/bg-group-mullsover-selling-half-of-40-stake-in-gnl-quintero-report-255939.

\section{B. UNDER CONSTRUCTION}

Colbun FSRU: Year from James Fowler, "Chile's Colbun FSRU project hits delays as supply talks begin," ICIS, April 25 2013, http://www.icis.com/resources/news/2013/04/25/9662659/chile-s-colbun-fsru-project-hitsdelays-as-supply-talks-begin/. Capacity and construction status from International Gas Union, World LNG Report, 52.

Gas Atacama FSRU: Year and cost from Alexandra Ulmer, "Chile GasAtacama sees over $\$ 4$ billion in LNG power deal with miners," Reuters, October 18, 2012, http://www.reuters.com/article/2012/10/18/us-chile-gasatacama-lngidUSBRE89H1A020121018. Capacity from Golar LNG, "Golar LNG: Golar Secures Chile's First FSRU Award,” July 5, 2012, http://www.golarlng.com/index.php?name=seksjon/Stock_Exchange_Releases/Press_Releases. $\mathrm{html} \&$ pressrelease $=1624765 \mathrm{html}$. Construction status from International Gas Union, World LNG Report, 52. 


\section{China}

\section{A. OPERATIONAL}

Dailan: Year and capacity from the International Group of Liquefied Natural Gas Importers, The $L N G$ Industry. Cost from ICIS, "PetroChina's Dalian terminal approved, on back of Gorgon and Browse LNG deals," http://www.icis.com/heren/articles/2008/02/08/9302226/petrochinasdalian-terminal-approved,-on-back-of-gorgon-and-browse-lng-deals.html.

Dapeng, Guangdong: Year and capacity from Bloomberg News, "China’s Liquefied Natural Gas Terminals," August 16, 2012, http://www.bloomberg.com/news/2012-08-16/china-s-liquefiednatural-gas-terminals-table-.html. Cost from Hydrocarbons Technology, "Guangdong Liquefied Natural Gas, China," http://www.hydrocarbons-technology.com/projects/guangdong-lngterminal/.

Fujian: Year and capacity from International Gas Union, World LNG Report, 52. Cost from China National Offshore Oil Corp. Website, "Fujian LNG Phase II Commences Construction," http://en.cnooc.com.cn/data/html/news/2012-07-31/english/324567.html.

Rudong, Jiangsu: Year and capacity from the International Group of Liquefied Natural Gas Importers, The LNG Industry. Cost from Jing Yang, "Jiangsu LNG Terminal Gains Chinese Government Approval," Resource Investor, March 23, 2007,

http://www.resourceinvestor.com/2007/03/23/jiangsu-lng-terminal-gains-chinese-governmentappr.

Shanghai, Mengtougou: Year and capacity from the International Group of Liquefied Natural Gas Importers, The LNG Industry in 2012.

Shanghai LNG: Year and capacity from the International Group of Liquefied Natural Gas Importers, The LNG Industry. Cost from Hydrocarbons Technology, "Shanghai LNG Project, China," http://www.hydrocarbons-technology.com/projects/shanghai-lng/.

Tangshan LNG: Year and capacity from Platts, "PetroChina's Tangshan LNG import terminal starts commercial operations," December 11 2013, http://www.platts.com/latest-news/naturalgas/singapore/petrochinas-tangshan-lng-import-terminal-starts-27723562.

Tianjin: Year and capacity from Song Yen Ling, "China's CNOOC receives first LNG cargo at Tianjin FSRU,” Platts, November 26, 2013, http://www.platts.com/latest-news/naturalgas/singapore/chinas-cnooc-receives-first-lng-cargo-at-tianjin-27666510. Cost from Joao Peixe, "China Prepares for First Delivery to Floating LNG Terminal," Oilprice.com, November 6, 2013, http://oilprice.com/Latest-Energy-News/World-News/China-Prepares-for-First-Deliveryto-Floating-LNG-Terminal.html.

Zhejiang, Ningbo: Year and capacity from the International Group of Liquefied Natural Gas Importers, The LNG Industry. Cost from Hydrocarbons Technology, "Zhejiang Ningbo LNG Terminal, China," http://www.hydrocarbons-technology.com/projects/zhejiang-ningbo-lngterminal-china/.

\section{B. UNDER CONSTRUCTION}

Guangxi / Beihai: Year, capacity, and cost from Chen Aizhu, "Sinopec's \$2.8 bln LNG terminal to win approval soon - source," Reuters, January 19, 2012, http://www.reuters.com/article/2012/01/20/china-lng-beihai-idUSL3E8CK12X20120120. Construction status from International Gas Union, World LNG Report, 52. 
Hainan LNG: Year and capacity from Sofregaz, "Hainan - China - LNG Receiving Terminal," 2009, http://www.sofregaz.fr/en/news/2009/hainan-china-lng-receiving-terminal. Cost from Zhao Tingting, "CNOOC gets nod from Hainan LNG project," China Daily USA, July 20, 2011, http://www.chinadaily.com.cn/m/hainan/dutyfree/2011-07/20/content_13049093.htm. Construction status from China National Offshore Oil Corp. website, "CNOOC Starts Construction on Hainan LNG Project," news release August 2 2011, http://en.cnooc.com.cn/data/html/news/2011-08-01/english/302477.html.

Shandong Qingdao: Year and capacity from the International Group of Liquefied Natural Gas Importers, The LNG Industry. Cost from Fanny Zhang, "China's Sinopec to start up Qingdao LNG terminal in November 2013," ICIS, September 21, 2011, http://www.icis.com/Articles/2011/09/21/9493841/chinas-sinopec-to-start-up-qingdao-lngterminal-in-november.html. Construction status from ICIS website, "China's Sinopec targets LNG market entry by October," January 9 2014,

http://www.icis.com/heren/articles/2014/01/09/9741828/lng/glm/chinas-sinopec-targets-lngmarket-entry-by-october.html.

Shenzhen Diefu: Year, capacity, cost and construction status from China National Offshore Oil Corp. Website, "Shenzhen Diefu LNG Receiving Terminal Starts Construction," September 3, 2012, http://en.cnooc.com.cn/data/html/news/2012-09-02/english/326841.html.

Yuedong / Jieyang LNG: Year from Holman Fenwick Willan, "Feeding the Dragon," July 2012, http://www.hfw.com/Feeding-the-dragon. Capacity, cost and construction status from China National Offshore Oil Corp. website, "CNOOC Yuedong LNG Project Lays Foundation," News Release, December 11, 2010, http://en.cnooc.com.cn/data/html/news/2010-1210/english/301873.html.

\section{PROPOSED/ANNOUNCED}

Dalian Expansion: Year and capacity from the International Group of Liquefied Natural Gas Importers, "Database for QFlex-QMax Acceptability."

Rudong Expansion: Year and capacity from LGC Fuel website, "Jiangsu Rudong LNG Terminal," http://www.lgcfuel.com/jiangsu-rudong-lng-terminal-china/.

Shanghai Expansion: Year from the International Group of Liquefied Natural Gas Importers, "Database for QFlex-QMax Acceptability." Capacity from LGC Fuel website, "Shanghai LNG Terminal," http://www.lgcfuel.com/shanghai-lng-terminal-china/.

Tianjin Phase 2: Year from the International Group of Liquefied Natural Gas Importers, "Database for QFlex-QMax Acceptability." Capacity and cost from Judy Hua and David Stanway, "UPDATE 1-China approves first floating terminal for LNG imports," Reuters, August 14 2013, http://www.reuters.com/article/2013/08/14/china-cnooc-lngidUSL4N0GF24C20130814.

Wenzhou Project Terminal: Cost and capacity from SinoShip News, "Wenzhou to start major LNG project," April 2, 2013, http://sinoshipnews.com/news_content.php?fid=3w3c1175.

Zhejiang Ningbo Phase II: Year, capacity and cost from Hydrocarbons Technology, "Zhejiang Ningbo LNG Terminal, China," http://www.hydrocarbons-technology.com/projects/zhejiangningbo-lng-terminal-china/.

Zhoushan: Year, capacity and cost from LNG World News website, "China Approves LNG Bunkering Project in Zhoushan," August 19 2013, http://www.lngworldnews.com/chinaapproves-lng-bunkering-project-in-zhoushan/. 


\section{Colombia}

\section{A. UNDER CONSTRUCTION}

Puerto Bahia: Year, cost and capacity from James Fowler, "Puertoa Bahia set for 2014 start," BN Americas, http://www.bnamericas.com/news/oilandgas/puerto-bahia-set-for-2014-start.

\section{B. PROPOSED/ANNOUNCED}

Colombia LNG: Year, capacity, and cost from Chris Kraul, "Colombia to build \$400 million LNG Regasification Plant: Official,” Platts, December 13, 2013, http://russia.platts.com/latestnews/natural-gas/bogota/colombia-to-build-400-million-lng-regasification-21919588.

\section{Croatia}

\section{A. PROPOSED/ANNOUNCED}

LNG Hrvatska: Year, capacity and cost from Igor Ilic, "Croatia confirms plans for new LNG terminal in 2016," Reuters, July 3, 2012, http://www.reuters.com/article/2012/07/03/croatialng-project-idUSL6E8I36O620120703.

\section{Dominican Republic}

\section{A. OPERATIONAL}

Punta Caucedo: Year and capacity from the International Group of Liquefied Natural Gas Importers, The LNG Industry in 2012.

\section{El Salvador}

\section{A. PROPOSED/ANNOUNCED}

CECAM: Year and capacity from the International Group of Liquefied Natural Gas Importers, "Database for QFlex-QMax Acceptability." Cost from Cutuco Energy, "Overview," http://www.cecalng.com/project0.htm.

\section{Estonia}

\section{A. PROPOSED/ANNOUNCED}

Muuga LNG: Year and capacity from Kari Liuhto, "A liquefied natural gas terminal boom in the Baltic Sea region?” Electronic Publications of the Pan-European Institute, May 2012, http://www.utu.fi/fi/yksikot/tse/yksikot/PEI/raportit-jatietopaketit/Documents/Liuhto\%20LNG.pdf. Cost from Juhan Tere, "Elering: our LNG terminal in Muuga port would be by 30\% cheaper," The Baltic Course, September 6, 2012, http://www.baltic-course.com/eng/energy/?doc $=62428$.

Paldiski: Year and capacity from the International Group of Liquefied Natural Gas Importers, "Database for QFlex-QMax Acceptability." Cost from LNG World News, "Balti Gaas: LNG Terminal in Paldiski to Cost 350 Million EUR (Estonia)," January 7, 2011, http://www.lngworldnews .com/balti-gaas-lng-terminal-in-paldiski-to-cost-eur-350-millionestonia/. 


\section{Finland}

\section{A. PROPOSED/ANNOUNCED}

Joddbole/Tolkinnen: Year and capacity from the International Group of Liquefied Natural Gas Importers, "Database for QFlex-QMax Acceptability."

\section{France}

\section{A. OPERATIONAL}

Fos-sur-Mer: Year and capacity from the International Group of Liquefied Natural Gas Importers, The LNG Industry in 2012.

Fos-Cavaou: Year and capacity from the International Group of Liquefied Natural Gas Importers, The LNG Industry in 2012.

Montoir- de-Bretagne: Year and capacity from the International Group of Liquefied Natural Gas Importers, The LNG Industry in 2012.

\section{B. UNDER CONSTRUCTION}

Dunkerque LNG: Year and capacity from the International Group of Liquefied Natural Gas Importers, The LNG Industry. Cost from Hydrocarbons Technology, "Dunkirk LNG Terminal, France," http://www.hydrocarbons-technology.com/projects/dunkirklngterminal. Construction status from International Gas Union, World LNG Report, 52.

\section{PROPOSED/ANNOUNCED}

Le Havre: Year, cost, and capacity from Gaz de Normandie, "Gas de Normandie has lodged its application for permission to operate the Antifer LNG Terminal," November 5, 2009, http://gazdenormandie.com/tl_files/documents/CP\%205\%20nov\%202009_EN.pdf.

Fos Faster: Year, cost and capacity from Doris Leblond, "Fos Faster LNG terminal given goahead," Oil \& Gas Journal, May 25, 2012, http://www.ogj.com/articles/2011/05/fos-faster-lngterminal.html.

\section{Greece}

\section{A. OPERATIONAL}

Revithoussa: Year and capacity from the International Group of Liquefied Natural Gas Importers, The LNG Industry in 2012.

\section{B. PROPOSED/ANNOUNCED}

Revithoussa Expansion: Year and capacity from the International Group of Liquefied Natural Gas Importers, "Database for QFlex-QMax Acceptability." 


\section{India}

\section{A. OPERATIONAL}

Dahbol: Year and capacity from Oil and Gas Journal, "GAIL Comissions Dahbol LNG Terminal, plans expansions," January 22, 2013, http://www.ogj.com/articles/2013/01/gailcommissions-dabhol-lng-terminal--plans-expansions.html. Cost from Sudheer Pal Singh, "India's Third LNG Terminal at Dahbol in Oct," Rediff Business, June 15, 2009, http://business.rediff.com/report/2009/jun/15/dpc-indias-third-lng-terminal-at-dabhol-inoct.htm.

Dahej: Capacity and cost from Petronet LNG, "LNG Terminal Dahej (Gujarat), India," http://rsinfotech.com/work/web/allwebsite/pll/lngterminals.htm.

Dahej Expansion: Capacity from Press Trust of India, “ADB to give $\$ 150 \mathrm{mn}$ loan for Petronet's Dahej LNG expansion,” Business Standard, December 17, 2013, http://www.businessstandard.com/article/companies/adb-to-give-150-mn-loan-for-petronet-s-dahej-lng-expansion113121700818_1.html.

Hazira: Year and capacity from the International Group of Liquefied Natural Gas Importers, The LNG Industry in 2012. Cost from Hydrocarbons Technology, "Hazira LNG Terminal, India," http://www.hydrocarbons-technology.com/projects/haziralngterminalguj/.

Hazira Expansion: Year and capacity from the International Group of Liquefied Natural Gas Importers, The LNG Industry in 2013.

Kochi LNG: Year and cost from Zdravka Lyubomirova Traykova, "Petronet LNG terminal at Kochi port to start operations next week - report," SeeNews, August 9, 2013,

https://energy.seenews.com/news/petronet-lng-terminal-at-kochi-port-to-start-operations-nextweek-report-370997. Capacity from Hydrocarbons Technology, "Kochi LNG Terminal, India," http://www.hydrocarbons-technology.com/projects/kochi-lng-terminal/.

\section{B. UNDER CONSTRUCTION}

Dahej Expansion 1: Year, capacity and construction status from the International Group of Liquefied Natural Gas Importers, The LNG Industry in 2013.

\section{PROPOSED/ANNOUNCED}

Dahej Expansion 2: Year, capacity and cost from Business Standard, "ADB to give \$150 mn loan for Petronet's Dahej LNG expansion," December 17, 2013, http://www.businessstandard.com/article/companies/adb-to-give-150-mn-loan-for-petronet-s-dahej-lng-expansion113121700818_1.html.

Ennore: Year, cost and capacity from The Hindu Business Line, "ONGC in talks to buy $26 \%$ stake in IOC's Ennore LNG terminal," January 17 2014, http://www.thehindubusinessline.com/companies/ongc-in-talks-to-buy-26-stake-in-iocs-ennorelng-terminal/article5585773.ece.

Gangavaram: Year and capacity from The Economic Times, "Petronet invites bids for Gangavaram LNG terminal," May 13, 2013, http://articles.economictimes.indiatimes.com/2013-05-13/news/39228716_1_kochi-terminallng-terminal-gangavaram-port.

Mundra: Year, cost and capacity from The Hindu, "RIL-BP front-runner for picking 25\% stake in Mundra Terminal," December 3, 2013, http://www.thehindu.com/business/Industry/rilbpfrontrunner-for-picking-25-stake-in-mundra-terminal/article5417890.ece. 
Ratnagiri (Dabhol) Expansion 1 and 2: Year and capacity from The Indian Express, "Gail commissions Dabhol LNG terminal in Ratnagiri," January 11, 2013, http://archive.indianexpress.com/news/gail-commissions-dabhol-lng-terminal-inratnagiri/1057766/.

\section{Indonesia}

\section{A. OPERATIONAL}

Nusantara FRSU: Year and capacity from the International Group of Liquefied Natural Gas Importers, The LNG Industry. Cost from Golar LNG, "Golar LNG Energy Wins Tender for West Java FSRU Project (Indonesia)," LNG World News, October 12, 2010, http://www.lngworldnews .com/indonesia-golar-lng-to-build-jakarta-fsru/.

\section{B. UNDER CONSTRUCTION}

Arun Conversion: Year, cost and capacity from Raras Cahyafitri, "Pertamina begins work on Arun gas facilities," The Jakarta Post, November 11, 2013, http://www.thejakartapost.com/news/2013/11/11/pertamina-begins-work-arun-gasfacilities.html. Construction status from the International Group of Liquefied Natural Gas Importers, The LNG Industry.

North Sumatra (Medan/Lampung) FSRU: Year and capacity from Priyambodo RH, "Lampung's floating gas terminal to be operational in 2014," Antara News, February 28, 2013, http://www.antaranews.com/en/news/87568/lampungs-floating-gas-terminal-to-be-operationalin-2014. Cost from Hoegh LNG, "Indonesia FRSU," http://www.hoeghlng.com/regas/Pages/Indonesia-FSRU.aspx. Construction status from International Gas Union, World LNG Report, 52.

\section{PROPOSED/ANNOUNCED}

East Java: Year from the International Group of Liquefied Natural Gas Importers, The LNG Industry. Capacity and cost from Pak Alfian, "Pertamina to build a \$200m LNG terminal in East Java," The Jakarta Post, January 19, 2010, http://www.thejakartapost.com/news/2010/01/19/pertamina-build-a-200m-lng-terminal-eastjava.html.

\section{Italy}

\section{A. OPERATIONAL}

Panigaglia: Year and capacity from the International Group of Liquefied Natural Gas Importers, The LNG Industry in 2012.

Porto Levante FRSU: Year and capacity from the International Group of Liquefied Natural Gas Importers, The LNG Industry. Cost from Aker Solutions, "Contract for the Isola di Porto Levante LNG Terminal project," News Release, http://www.akersolutions.com/en/Globalmenu/Media/Press-Releases/All/2005/Contract-for-the-Isola-di-Porto-Levante-LNG-Terminalproject/. 


\section{B. PROPOSED/ANNOUNCED}

Gioria Tauro: Year and capacity from the International Group of Liquefied Natural Gas Importers, "Database for QFlex-QMax Acceptability." Cost from World Construction Netwrok website, "MG/Sorgenia/Iride - Gioia Tauro LNG terminal, Calabria, Italy," August 26, 2013, http://www.worldconstructionnetwork.com/projects/mgsorgeniairide-gioia-tauro-lng-terminalcalabria-italy/.

Porto Empedocle: Year and capacity from the International Group of Liquefied Natural Gas Importers, "Database for QFlex-QMax Acceptability." Cost from Stephen Jewkes, "Enel sees Sicily LNG terminal operating in 2015," Reuters, February 8, 2011, http://www.reuters.com/article/2011/02/08/enel-lng-idAFLDE71724F20110208.

Panigaglia Expansion: Year from the International Group of Liquefied Natural Gas Importers, "Database for QFlex-QMax Acceptability." Capacity and cost from ICIS website, "Eni's import empire expands as Snam confirms Panigaglia expansion," Feburay 23, 2007, http://www.icis.com/heren/articles/2007/02/23/9294191/enis-import-empire-expands-as-snamconfirms-panigaglia-expansion.html.

Api Nova FSRU: Year and capacity from the International Group of Liquefied Natural Gas Importers, "Database for QFlex-QMax Acceptability."

Zaule: Year and capacity from the International Group of Liquefied Natural Gas Importers, "Database for QFlex-QMax Acceptability."

\section{Japan}

\section{A. OPERATIONAL}

Chita: Year and capacity from the International Group of Liquefied Natural Gas Importers, The LNG Industry in 2012.

Chita Kyodo: Year and capacity from the International Group of Liquefied Natural Gas Importers, The LNG Industry in 2012.

Chita-Midorihama Works: Year and capacity from the International Group of Liquefied Natural Gas Importers, The LNG Industry in 2012.

Fokuoka: Year and capacity from the International Group of Liquefied Natural Gas Importers, The LNG Industry in 2012.

Futtsu: Year and capacity from the International Group of Liquefied Natural Gas Importers, The LNG Industry in 2012.

Hatsukaichi: Year and capacity from the International Group of Liquefied Natural Gas Importers, The LNG Industry in 2012.

Higashi-Ohgishima: Year and capacity from the International Group of Liquefied Natural Gas Importers, The LNG Industry in 2012.

Himeji: Year and capacity from the International Group of Liquefied Natural Gas Importers, The LNG Industry in 2012.

Himeji LNG: Year and capacity from the International Group of Liquefied Natural Gas Importers, The LNG Industry in 2012. 
Ishikari LNG: Year and capacity from the International Group of Liquefied Natural Gas Importers, The LNG Industry in 2012.

Joetsu: Year and capacity from the International Group of Liquefied Natural Gas Importers, The LNG Industry in 2012.

Kagoshima: Year and capacity from the International Group of Liquefied Natural Gas Importers, The LNG Industry in 2012.

Kawagoe: Year and capacity from the International Group of Liquefied Natural Gas Importers, The LNG Industry in 2012.

Mizushima: Year and capacity from the International Group of Liquefied Natural Gas Importers, The LNG Industry in 2012.

Nagasaki: Year and capacity from the International Group of Liquefied Natural Gas Importers, The LNG Industry in 2012.

Negishi: Year and capacity from the International Group of Liquefied Natural Gas Importers, The LNG Industry in 2012.

Niigata: Year and capacity from the International Group of Liquefied Natural Gas Importers, The LNG Industry.

Ongishima: Year and capacity from the International Group of Liquefied Natural Gas Importers, The LNG Industry in 2012.

Oita: Year and capacity from the International Group of Liquefied Natural Gas Importers, The LNG Industry in 2012.

Sakai: Year and capacity from the International Group of Liquefied Natural Gas Importers, The LNG Industry in 2012.

Sakaide: Year and capacity from the International Group of Liquefied Natural Gas Importers, The LNG Industry in 2012.

Sedogaura: Year and capacity from the International Group of Liquefied Natural Gas Importers, The LNG Industry in 2012.

Senboku I and II: Year and capacity from the International Group of Liquefied Natural Gas Importers, The LNG Industry in 2012.

Shin-Minato: Year and capacity from the International Group of Liquefied Natural Gas Importers, The LNG Industry in 2012.

Sodeshi: Year and capacity from the International Group of Liquefied Natural Gas Importers, The LNG Industry in 2012.

Tobata: Year and capacity from the International Group of Liquefied Natural Gas Importers, The LNG Industry in 2012.

Yanai: Year and capacity from the International Group of Liquefied Natural Gas Importers, The LNG Industry in 2012.

Yokkaichi LNG Centre: Year and capacity from the International Group of Liquefied Natural Gas Importers, The LNG Industry in 2012.

Yokkaichi Works: Year and capacity from the International Group of Liquefied Natural Gas Importers, The LNG Industry in 2012. 


\section{B. UNDER CONSTRUCTION}

Hachinohe LNG: Year and capacity from the International Group of Liquefied Natural Gas Importers, The LNG Industry in 2013 (Paris: GIIGNL, 2012)..

Hibiki: Year and capacity from the International Group of Liquefied Natural Gas Importers, The LNG Industry in 2012.

Hitachi: Year from the International Group of Liquefied Natural Gas Importers, The LNG Industry in 2013.

Kushiro LNG: Year and capacity from the International Group of Liquefied Natural Gas Importers, The LNG Industry in 2013.

Naoetsu: Year and capacity from the International Group of Liquefied Natural Gas Importers, "Database for QFlex-QMax Acceptability." Cost from Hydrocarbons Technology, "Naoetsu LNG Receiving Terminal, Japan," http://www.hydrocarbons-technology.com/projects/naoetsulng-receiving-terminal/.

\section{PROPOSED/ANNOUNCED}

Shin-Sendai: Year and capacity from the International Group of Liquefied Natural Gas Importers, "Database for QFlex-QMax Acceptability."

Wakayama: Year and capacity from LNG Market website, "Wakayama LNG Terminal (Wakayama)," http://www.lngmarket.com/installation/Wakayama-LNG-Terminal-242.

\section{Kuwait}

\section{A. OPERATIONAL}

Mina al Ahmadi FRSU: Year and capacity from the International Group of Liquefied Natural Gas Importers, The LNG Industry in 2012.

\section{Latvia}

\section{A. PROPOSED/ANNOUNCED}

Riga: Year, capacity and cost from The Baltic Times, "Riga deemed best for LNG terminal," July 13, 2011, http://www.baltictimes.com/news/articles/29052/\#.UxDsu_mwLYg.

\section{Lithuania}

\section{A. UNDER CONSTRUCTION}

Hoegh FRSU: Year and capacity from the International Group of Liquefied Natural Gas Importers, The LNG Industry. Cost from Hoegh LNG, "Lithuania FRSU," http://www.hoeghlng.com/regas/Pages/Lithuania-FSRU.aspx. Construction status from Petroleum Economist, World LNG Factbook (London: Euromoney, 2013), http://www.petroleum-economist.com/pdf/LNGInsight_May/LNG\%20Importers.pdf.

Klaipeda FSRU: Year, capacity, cost and construction status from Joanna Hyndle-Hussein, "The Lithuanian LNG terminal in Klaipeda is to be operational in 2014," OSW, March 7, 2012, http://www.osw.waw.pl/en/publikacje/analyses/2012-03-07/lithuanian-lng-terminal-klaipeda-tobe-operational-2014. 


\section{Malaysia}

\section{A. OPERATIONAL}

Melaka: Year and capacity from the International Group of Liquefied Natural Gas Importers, The LNG Industry in 2013.

\section{Mexico}

\section{A. OPERATIONAL}

Altamira: Year and capacity from the International Group of Liquefied Natural Gas Importers, The LNG Industry in 2012. Cost from Fluor, "Ishikawajima-Harima Heavy Industries Co. Ltd. \& ICA Fluor Consortium Awarded First LNG Terminal in Mexico," News Release, December 18, 2003, http://investor.fluor.com/phoenix.zhtml?c=124955\&p=irolnewsArticle \&ID=479409\&highlight $=$.

Energía Costa Azul: Year and capacity from the International Group of Liquefied Natural Gas Importers, The LNG Industry in 2012. Cost from Energía Costa Azul Website, "Sempra LNG's Energía Costa Azul helps meet the energy needs of Baja California," http://eca.sempralng.com/about-us.html.

Manzanillo: Year and capacity from the International Group of Liquefied Natural Gas Importers, The LNG Industry in 2012. Cost from Samsung C\&T, "Samsung C\&T Completes Manzanillo LNG Terminal," News Release, March 28, 2012,

http://www.samsungent.com/EN/cnt/pr/401000/articleRead.do?board_id=6\&article_id=2209\&p age_index $=3$.

\section{B. PROPOSED/ANNOUNCED}

Topolobampo: Year and capacity from the International Group of Liquefied Natural Gas Importers, "Database for QFlex-QMax Acceptability."

\section{Netherlands}

\section{A. OPERATIONAL}

Gate LNG: Year and capacity from the International Group of Liquefied Natural Gas Importers, The LNG Industry in 2012. Cost from Green Car Congress, "Netherlands opens first LNG terminal; US\$1.1B GATE terminal has 12BCM annual throughput capacity," September 25, 2011, http://www.greencarcongress.com/2011/09/gate-201109025.html.

\section{Pakistan}

\section{A. PROPOSED/ANNOUNCED}

Marshal: Capacity from Haris Zamir, "Pakistan to invite fresh bids for $3.5 \mathrm{mil}$ mt/year LNG supply mid-Feb," Platts, January 31, 2011, http://www.platts.com/latestnews/oil/karachi/pakistan-to-invite-fresh-bids-for-35-mil-mtyear-8475527. Cost from Ahmad Ahmadani, "Multi-million dollars LNG import project in doldrums," The Nation, March 5, 2011, http://www.nation.com.pk/Business/05-Mar-2011/Multimillion-dollars-LNG-importproject-in-doldrums. 


\section{Panama}

\section{A. PROPOSED/ANNOUNCED}

Colon LNG: Year and capacity from the International Group of Liquefied Natural Gas Importers, "Database for QFlex-QMax Acceptability." Cost from Don Winner, "Panama to spend \$430 Million on LNG Terminal, Gas-Fired Plant," Panama Guide, January 21, 2010, http://www.panama-guide.com/article.php/new-lng-terminal-and-power-plant.

\section{Philippines}

\section{A. PROPOSED/ANNOUNCED}

Bataan-Manila: Year and capacity from LNG Market website, "Bataan-Manila LNG II (Batman II), http://www.Ingmarket.com/installation/Bataan-Manila-LNG-II-353. Cost from Alexander's Gas \& Oil Connections website, "PNOC plans completion of LNG facility by 2012," December 2, 2006, http://www.gasandoil.com/news/2007/01/cns70376.

Mariveles: Year and capacity from LNG Market website, "Mariveles LNG Terminal (Bataan I)," http://www.lngmarket.com/installation/Mariveles-LNG-(Bataan)-246.

\section{Poland}

\section{A. PROPOSED/ANNOUNCED}

Polskie LNG / Swinoujscie LNG: Year, capacity and construction status from the International Group of Liquefied Natural Gas Importers, The LNG Industry in 2013. Cost from Hydrocarbons Technology, "Swinoujscie LNG Gas Terminal, Poland," http://www.hydrocarbons-technology.com/projects/swinoujscie/.

\section{Portugal}

\section{A. OPERATIONAL}

Sines: Capacity from ICIS, "Portugal's Sines LNG terminal operator outlines expansion plans," March 27, 2009, http://www.icis.com/heren/articles/2009/03/27/9310651/portugals-sines-lngterminal-operator-outlines-expansion-plans.html.

Sines Expansion: Capacity from Somague, "Sines LNG Terminal Expansion Project inaugurated," September 25, 2012, http://www.somague.pt/site/shownews.asp?lg=en\&idn=833.

\section{Puerto Rico}

\section{A. OPERATIONAL}

Penuelas: Year and capacity from the International Group of Liquefied Natural Gas Importers, The LNG Industry in 2012. Cost from Zeus Intelligence, "LNG Import Terminal Profile: EcoEléctrica LP - LNG terminal, Guayanilla Bay, Puerto Rico,” December 15, 2005, http://member.zeusintel.com/ZLNGR/show_image.aspx?id=1669. 


\section{B. PROPSED/ANNOUNCED}

Aguirre FSRU: Year from Aguirre Offshore Gasport website, "Project Status and Timeline," http://en.aguirreoffshoregasport.com/the-aguirre-offshore-gasport-project-overview/gasportproject-status-and-timeline/. Capacity from Aguirre Offshore Gasport website, "Project Site Plan," http://en .aguirreoffshoregasport.com/the-aguirre-offshore-gasport-project-overview/lnggasport-project-site-plans/.

\section{Singapore}

\section{A. OPERATIONAL}

Singapore LNG Phase 1-2: Year and capacity from Singapore LNG Corp., "Prime Minister Lee Hsien Loong Officially Opens the Singapore LNG Terminal," News Release, February 25, 2014, http://www.slng.com.sg/newsroom-press-release-20140225.html. Cost from Hydrocarbons Technology, "Singapore LNG Terminal, Jurong Island, Singapore," http://www.hydrocarbons-technology.com/projects/singaporelngterminal/.

\section{B. PROPOSED/ANNOUNCED}

Singapore LNG Phase 3: Year from Cou Hui Hong and Ramsey Al-Rikabi, "Singapore Bids for Role as LNG Hub With Second Terminal," Bloomberg, February 25, 2014, http://www.bloomberg.com/news/2014-02-25/singapore-plans-to-build-second-lng-terminal-incountry-s-east.html. Capacity from Singapore LNG Corp., "Prime Minister Lee Hsien Loong Officially Opens the Singapore LNG Terminal," News Release, February 25, 2014, http://www.slng.com.sg/newsroom-press-release-20140225.html.

\section{South Korea}

\section{A. OPERATIONAL}

Gwangyang: Year and capacity from the International Group of Liquefied Natural Gas Importers, The LNG Industry in 2012. Cost from Gas and Oil Connections, "POSCO Completes LNG Terminal in Gwangyang," July 7, 2005, http://www.gasandoil.com/news/south_east_asia/fff7fe41c85dd715f16f54514fd2d5b2?b_start= 9520 .

Incheon: Year and capacity from the International Group of Liquefied Natural Gas Importers, The LNG Industry in 2012.

Pyeong-Taek: Year and capacity from the International Group of Liquefied Natural Gas Importers, The LNG Industry in 2012.

Tong-Yeong: Year and capacity from the International Group of Liquefied Natural Gas Importers, The LNG Industry in 2012.

\section{B. UNDER CONSTRUCTION}

Samcheok: Year, capacity and construction status from International Gas Union, World LNG Report, 52. Cost from Charles Lee, "S Korea's LNG demand to fall $1.5 \%$ to $38.29 \mathrm{mil} \mathrm{mt}$ by 2027: energy ministry," Platts, April 30, 2013, http://www.platts.com/latest-news/naturalgas/seoul/s-koreas-lng-demand-to-fall-15-to-3829-mil-mt-27927622. 


\section{PROPOSED/ANNOUNCED}

Borycong: Year, capacity and cost from Yonhap News Agency website, "Two Korean firms to build US\$681 mln LNG terminal in S. Korea,” May 15, 2013, http://english.yonhapnews.co.kr/news/2013/05/15/71/0200000000AEN20130515006700320F.H TML.

Smacheok Expansion: Year and capacity from the International Group of Liquefied Natural Gas Importers, "Database for QFlex-QMax Acceptability."

\section{Spain}

\section{A. OPERATIONAL}

Barcelona: Year and capacity from the International Group of Liquefied Natural Gas Importers, The LNG Industry in 2012.

Bilbao: Capacity and cost from David Nakamura, "BP Amoco and partners sanction major 'wellhead to wire' integrated energy project," Hydrocarbon Online, June 26, 2000, http://www.hydrocarbononline.com/doc/bp-amoco-and-partners-sanction-major-wellhead-0001.

Bilbao Expansion: Capacity from the International Group of Liquefied Natural Gas Importers, The LNG Industry in 2012. Year from A Barrel Full, "Bilbao LNG Terminal," December 2, 2013, http://abarrelfull.wikidot.com/bilbao-lng-terminal.

Cartagena: Year and capacity from the International Group of Liquefied Natural Gas Importers, The LNG Industry in 2012.

El Musel: Year from the International Group of Liquefied Natural Gas Importers, The LNG Industry in 2012, 27. Capacity from the International Group of Liquefied Natural Gas Importers, The LNG Industry in 2011 (Paris: GIIGNL, 2011).

Huelva: Year and capacity from the International Group of Liquefied Natural Gas Importers, The LNG Industry in 2012.

Mugardos: Year and capacity from the International Group of Liquefied Natural Gas Importers, The LNG Industry in 2012. Cost from Zeus Intelligence, "LNG Import Terminal Profile: Murgardos LNG terminal, Galicia, Spain," February 15, 2006, http://member.zeusintel.com/ZLNGR/show_image.aspx?id=1918.

Sagunto: Year and capacity from the International Group of Liquefied Natural Gas Importers, The LNG Industry in 2012. Cost from Zeus Intelligence, "LNG Import Terminal Profile: Sagunto, Valencia, Spain," February 15, 2006, http://member.zeusintel.com/ZLNGR/show_image.aspx?id=1917.

\section{B. UNDER CONSTRUCTION}

Bilbao Expansion 2: Year, capacity and construction status from International Gas Union, World LNG Report 2013.

Tenerife: Year and capacity from LNG market website, "Tenerife LNG Terminal (Tenerife)," http://www.lngmarket.com/installation/Tenerife-LNG-Terminal-83\#/Tenerife-LNG-Terminal83. Construction status from the International Group of Liquefied Natural Gas Importers, "Database for QFlex-QMax Acceptability." 


\section{PROPOSED/ANNOUNCED}

Gran Canaria: Year and capacity from LNG market website, "Gran Canaria LNG Terminal (Gran Canaria)," http://www.lngmarket.com/installation/Gran-Canaria-LNG-Terminal-80\#/GranCanaria-LNG-Terminal-80.

\section{Sweden}

\section{A. UNDER CONSTRUCTION}

Gothenburg LNG Terminal: Year and capacity from Kari Liuhto, "A liquefied natural gas terminal boom in the Baltic Sea region?" Electronic Publications of the Pan-European Institute, May 2012, http://www.utu.fi/fi/yksikot/tse/yksikot/PEI/raportit-jatietopaketit/Documents/Liuhto\%20LNG.pdf. Cost from Port of Gothenburg website, "New terminal for liquefied natural gas," February 11, 2011, http://www.portofgothenburg.com/News-desk/News-articles/New-terminal-for-liquefiednatural-gas/. Construction status from Port of Gothenburg website, "LNG terminal at the Port of Gothenburg," September 18, 2013, http://www.portofgothenburg.com/About-theport/Sustainable-port/Liquefied-natural-gas--LNG/LNG-terminal-at-the-Port-of-Gothenburg-/.

\section{Taiwan}

\section{A. OPERATIONAL}

Yung-An: Year and capacity from the International Group of Liquefied Natural Gas Importers, The LNG Industry in 2012.

Taichung: Year and capacity from the International Group of Liquefied Natural Gas Importers, The LNG Industry in 2012. Cost from LGC Fuel, "Taichung LNG Terminal Taiwan," http://www.lgcfuel.com/taichung-lng-terminal-taiwan/.

\section{B. PROPOSED/ANNOUNCED}

Taipei LNG: Year and capacity from Platts, "Taiwan's CPC finalizes location of third LNG terminal, says chairman,” September 19, 2012, http://www.platts.com/latest-news/naturalgas/tokyo/taiwans-cpc-finalizes-location-of-third-lng-terminal-7079593.

\section{Thailand}

\section{A. OPERATIONAL}

Map Ta Phut: Year and capacity from the International Group of Liquefied Natural Gas Importers, The LNG Industry in 2012. Cost from Hydrocarbons Technology, "Map Ta Phut LNG Regasification Terminal, Thailand," http://www.hydrocarbonstechnology.com/projects/thailandptt/.

\section{B. PROPOSED/ANNOUNCED}

Map Ta Phut Expansion: Year and capacity from PTT LNG website, "Company Information," http://www.pttlng.com/en/pj_composition.aspx. Status from PTT LNG website, "Project Milestones," http://www.pttlng.com/en/pj_mile.aspx. 


\section{Turkey}

\section{A. OPERATIONAL}

Aliaga/Izmir: Year and capacity from the International Group of Liquefied Natural Gas Importers, The LNG Industry in 2012. Cost from King and Spalding, LNG in Europe (2006), 27, http://www.kslaw.com/library/pdf/LNG_in_Europe.pdf.

Marmara Ereglisi: Year and capacity from the International Group of Liquefied Natural Gas Importers, The LNG Industry in 2012. Cost from Zeus Intelligence, "LNG Import Terminal Profile: Marmara Ereglisi, Turkey," May 1, 2005, http://member.zeusintel.com/ZLNGR/show_image.aspx?id=1149.

\section{Ukraine}

\section{A. PROPOSED/ANNOUNCED}

Black Sea LNG: Year and capacity from the International Group of Liquefied Natural Gas Importers, "Database for QFlex-QMax Acceptability." Cost from Invest Ukraine website, "Direct Expenses of Ukraine on LNG Terminal National Project will Equal to 3-day Payment to Gazprom," March 30, 2012, http://investukraine.com/5127-direct-expenses-of-ukraine-onlng-terminal-national-project-will-equal-to-3-day-payment-to-gazprom.

Port of Yuzhny FSRU: Year and cost from Investment Port of Kyiv Region website, "LNGterminal construction will start in Yuzhny in November - Kaskiv," http://investkoda.gov.ua/en/lng-terminal-construction-will-start-in-yuzhny-in-november-kaskiv/. Capacity from the International Group of Liquefied Natural Gas Importers, The LNG Industry in 2012.

\section{United Arab Emirates}

\section{A. OPERATIONAL}

Jebel Ali FRSU: Year and capacity from the International Group of Liquefied Natural Gas Importers, The LNG Industry in 2012.

\section{United Kingdom}

\section{A. OPERATIONAL}

Isle of Grain Train 1-3: Year from National Grid plc website, "National Grid Grain LNG: UK leaders in LNG importation," http://www.nationalgrid.com/NR/rdonlyres/F57A356F-603E4738-ABFF-26920C061A71/41131/GrainBrochure0209.pdf. Cost and capacity from Ben Farey, "U.K. Isle of Grain LNG Terminal's Expansion Delayed, Grid Says," Bloomberg, November 29, 2010, http://www.bloomberg.com/news/2010-11-29/u-k-isle-of-grain-lngterminal-s-expansion-delayed-grid-says.html.

Dragon: Year and capacity from the International Group of Liquefied Natural Gas Importers, The LNG Industry in 2012. Cost from Hydrocarbons Technology, "Dragon LNG Terminal, United Kingdom," http://www.hydrocarbons-technology.com/projects/dragon-lng/.

South Hook: Year and capacity from the International Group of Liquefied Natural Gas Importers, The LNG Industry in 2012. Cost from South Hook LNG, South Hook LNG Seasons, $1,2012,4$, http://www.southhooklng.com/uploads/newsletters/SHLNGAutumnNewsletter2012.pdf. 
Teesside FRSU: Year and capacity from the International Group of Liquefied Natural Gas Importers, The LNG Industry in 2012.

\section{U.S.A.}

\section{A. OPERATIONAL}

Cameron LNG: Year and capacity from the International Group of Liquefied Natural Gas Importers, The LNG Industry in 2012.

Cove Point: Capacity from Dominion Virginia Power Website, "Growth at Dominion Cove Point LNG." Mothball Information from Dominion Virginia Power Website, "History of Cove Point," https://www.dom.com/business/gas-transmission/cove-point/history-of-cove-point.jsp

Cove Point Expansion I: Year and capacity from the International Group of Liquefied Natural Gas Importers, The LNG Industry in 2012.

Cove Point Expansion II: Year and capacity from Dominion Virginia Power Website, "Growth at Dominion Cove Point LNG," https://www.dom.com/dominion-virginia-power/poweringvirginia/dominion-cove-point.jsp.

Elba Island: Year and capacity from Hydrocarbons Technology, "Elba Island LNG Terminal, United States of America," http://www.hydrocarbons-

technology.com/projects/elbaislandlngtermina/. Mothball Information from California Energy Commission, "Significant Events of LNG History," http://www.energy.ca.gov/lng/documents/SIGNIFICANT_EVENTS_LNG_HISTORY.PDF.

Everett: Year and capacity from the International Group of Liquefied Natural Gas Importers, The LNG Industry in 2012.

Freeport LNG: Year and capacity from the International Group of Liquefied Natural Gas Importers, The LNG Industry in 2012. Cost from Port Freeport, "State of the Port 2009" Presentation, Slide 17, http://www.portfreeport.com/about_files/StateofthePort2009.pdf.

Golden Pass: Year and capacity from the International Group of Liquefied Natural Gas Importers, The LNG Industry. Cost from GCaptain, "ExxonMobil and Qatar Submit \$10 Billion Request to Export LNG From the US Gulf Coast," August 17, 2012. http://gcaptain.com/exxonmobil-qatar-submit-billion/

Gulf LNG Energy: Year and capacity from the International Group of Liquefied Natural Gas Importers, The LNG Industry in 2012. Cost from Ellen Mitchell, "Pascagoula's LNG importing facility could see exports as well," Alabama.com, June 27, 2012, http://blog.al.com/pressregister-business/2012/06/pascagoulas_lng_importing_faci.html.

Lake Charles: Year and capacity from Hydrocarbons Technology, "Trunkline LNG Lake Charles Terminal, Louisiana, United States of America," http://www.hydrocarbonstechnology.com/projects/trunklinelnglakechar/.

Neptune LNG FRSU: Year and capacity from the International Group of Liquefied Natural Gas Importers, The LNG Industry in 2012. Cost from Fitzgerald, "2 Costly LNG Terminals."

Northeast Gateway FRSU: Year and capacity from the International Group of Liquefied Natural Gas Importers, The LNG Industry in 2012. Cost from Jay Fitzgerald, "2 Costly LNG Terminals Sit Idle," The Boston Globe, January 23, 2013, https://www.bostonglobe.com/business/2013/01/23/offshore-gas-terminals-mass-bustfar/Qu8dyZzF6yBNAsDNaTT1ZJ/story.html. 
Sabine Pass: Year and capacity from the International Group of Liquefied Natural Gas Importers, The LNG Industry in 2012. Cost from Rigzone, "Cheniere Completes Sabine Pass LNG Terminal in 3Q 2009," November 6, 2009, http://www.rigzone.com/news/oil_gas/a/82193/Cheniere_Completes_Sabine_Pass_LNG_Termi nal_in_3Q_2009. 


\section{About the Authors}

Michal C. Moore, $(\mathrm{PhD})$ is an economist and Professor of Energy Economics at The School of Public Policy at the University of Calgary. $\mathrm{He}$ is the former chief economist at the U.S. National Renewable Laboratory in Golden Colorado, where he led a research team engaged in examining over-the-horizon issues for the U.S. Department of Energy and developing new methods for cross-cutting analysis. He is an economist and a former commissioner with the California Energy Commission, where he held the designated economist position.

Dave Hackett has been a participant in all the recent developments in the transportation fuels industry. Leveraging a Supply and Trading background at Mobil, Dave started Stillwater Associates in 1998. Since then, Stillwater's work on issues like the MTBE phase out, gasoline price controls, corn ethanol distribution, biodiesel production, next generation renewable fuels implementation, price gouging, fuels infrastructure constraints, mergers and acquisitions, interstate commerce, low carbon fuel standard, crude oil logistics, and refining technology have helped to make the firm a leading force in the transportation fuels space.

Leigh Noda has had a long career in the petroleum products and energy business. After earning a degree in Chemical Engineering from UC Davis and an MBA from UCLA, he was with ARCO through 1980. Leigh's ARCO career included managerial assignments in refining technology, refining operations, strategic planning, international business development, project development \& economics, and environmental, health and safety. A consultant in the refining and fuels business for the past fourteen years, he has been affiliated with Stillwater Associates since 2010.

Jennifer Winter, $(\mathrm{PhD})$ is the Associate Director for the Energy and Environmental Policy area at The School of Public Policy. Her research is focused on the effects of government regulation on the development of natural resources. Jennifer has authored several research papers for The School, including three on Canadian energy literacy. Prior to joining The School, she worked at Human Resources and Skills Development Canada in Ottawa, analysing Canadian labour markets.

Roman Karski is a Regulatory Analyst at TransCanada. He formerly worked as a Research Assistant at The School of Public Policy, specializing in LNG markets and policy. He holds a Bachelor of Arts in Economics (Applied Energy Concentration), as well as a Master of Public Policy from the University of Calgary.

Mark Pilcher worked in the energy industry for 38 years for BP, ARCO (acquired by BP in 2000), and First Interstate Bank (subsequently acquired by Wells Fargo). He has experience in all phases of oil and gas exploration and production, and LNG projects: exploration, appraisal, development, operations, market assessment, market development, commercial contracts, LNG plants and import terminals, shipping and finance. He has worked in technical and commercial management roles, and negotiated Joint Venture Agreements, Operating Agreements, and LNG Sales \& Purchase Agreements. He has a proven track record in building and leading multi-disciplinary, multi-cultural business development teams. 


\title{
ABOUT THE SCHOOL OF PUBLIC POLICY
}

The School of Public Policy will become the flagship school of its kind in Canada by providing a practical, global and focused perspective on public policy analysis and practice in areas of energy and environmental policy, international policy and economic and social policy that is unique in Canada.

The mission of The School of Public Policy is to strengthen Canada's public service, institutions and economic performance for the betterment of our families, communities and country. We do this by:

- Building capacity in Government through the formal training of public servants in degree and non-degree programs, giving the people charged with making public policy work for Canada the hands-on expertise to represent our vital interests both here and abroad;

- Improving Public Policy Discourse outside Government through executive and strategic assessment programs, building a stronger understanding of what makes public policy work for those outside of the public sector and helps everyday Canadians make informed decisions on the politics that will shape their futures;

- Providing a Global Perspective on Public Policy Research through international collaborations, education, and community outreach programs, bringing global best practices to bear on Canadian public policy, resulting in decisions that benefit all people for the long term, not a few people for the short term.

\author{
The School of Public Policy \\ University of Calgary, Downtown Campus \\ 906 8th Avenue S.W., 5th Floor \\ Calgary, Alberta T2P $1 \mathrm{H} 9$ \\ Phone: 4032107100
}

\section{DISTRIBUTION}

Our publications are available online at www.policyschool.ca.

\section{DISCLAIMER}

The opinions expressed in these publications are the authors' alone and therefore do not necessarily reflect the opinions of the supporters, staff, or boards of The School of Public Policy.

\section{COPYRIGHT}

Copyright (C) 2014 by The School of Public Policy.

All rights reserved. No part of this publication may be reproduced in any manner whatsoever without written permission except in the case of brief passages quoted in critical articles and reviews.

\section{ISSN}

1919-112x SPP Research Papers (Print)

1919-1138 SPP Research Papers (Online)

\section{DATE OF ISSUE}

July 2014

\section{MEDIA INQUIRIES AND INFORMATION}

For media inquiries, please contact Morten Paulsen at 403-453-0062.

Our web site, www.policyschool.ca, contains more information about The School's events, publications, and staff.

\section{DEVELOPMENT}

For information about contributing to The School of Public Policy, please contact Courtney Murphy by telephone at 403-210-7201 or by e-mail at cdmurphy@ucalgary.ca. 


\section{RECENT PUBLICATIONS BY THE SCHOOL OF PUBLIC POLICY}

WHO, OR WHAT, IS TO BLAME FOR THE ACCUMULATION OF DEBT IN ONTARIO AND QUEBEC (AND WHAT WILL IT TAKE TO STOP THE BLEEDING?)

http://policyschool.ucalgary.ca/sites/default/files/research/kneebone-ontdebt3.pdf

Margarita Wilkins and Ron Kneebone | July 2014

THE IMPACT OF FOREIGN INVESTMENT RESTRICTIONS ON THE STOCK RETURNS OF OIL SANDS COMPANIES

http://policyschool.ucalgary.ca/sites/default/files/research/beaulieau-foreign-inv.pdf

Eugene Beaulieu and Matthew Saunders | June 2014

FROM TRIAL TO TRIUMPH: HOW CANADA'S PAST FINANCIAL CRISES HELPED SHAPE A SUPERIOR REGULATORY SYSTEM

http://policyschool.ucalgary.ca/sites/default/files/research/savage-financeevol.pdf

Lawrie Savage | May 2014

THE FREE RIDE IS OVER: WHY CITIES, AND CITIZENS, MUST START PAYING FOR MUCH-NEEDED INFRASTRUCTURE

http://policyschool.ucalgary.ca/sites/default/files/bazelmintz-urban-growth.pdf

Philip Bazel and Jack Mintz | May 2014

ALBERTA CITIES AT THE CROSSROADS: URBAN DEVELOPMENT CHALLENGES AND OPPORTUNITIES IN HISTORICAL AND COMPARATIVE PERSPECTIVE http://policyschool.ucalgary.ca/sites/default/files/research/taylor-ab-cities-5.pdf

Anna Kramer, Marcy Burchfield and Zack Taylor | May 2014

ONTARIO'S EXPERIMENT WITH PRIMARY CARE REFORM

http://policyschool.ucalgary.ca/sites/default/files/ontario-health-care-reform.pdf

Gioia Buckley / Arthur Sweetman | May 2014

THE MIDDLE POWER AND THE MIDDLE KINGDOM: SECURING CANADA'S PLACE IN THE NEW CHINA-U.S. ECONOMIC AND STRATEGIC WORLD ORDER http://policyschool.ucalgary.ca/sites/default/files/dobson-china-communique.pdf

Wendy Dobson | April 2014

SAFETY IN NUMBERS: EVALUATING CANADIAN RAIL SAFETY DATA

http://policyschool.ucalgary.ca/sites/default/files/research/winter-rail-safety-communique.pdf Jennifer Winter | April 2014

CHINA'S STATE-OWNED ENTERPRISES AND CANADA'S FDI POLICY

http://policyschool.ucalgary.ca/sites/default/files/research/dobson-china.pdf

Wendy Dobson | March 2014

THE TAMING OF THE SKEW: FACTS ON CANADA'S ENERGY TRADE

http://policyschool.ucalgary.ca/sites/default/files/research/tombe-can-energytrade.pdf

Trevor Tombe | March 2014

CANADA-KOREA FREE TRADE: A WATERSHED IN ECONOMIC INTEGRATION WITH ASIA

http://policyschool.ucalgary.ca/sites/default/files/research/canada-korea-trade.pdf

Eugene Beaulieu | March 2014

KEEPING THE GENIE IN THE BOTILE: GRADING THE REGULATION OF CANADIAN FINANCIAL INSTITUTIONS

http://policyschool.ucalgary.ca/sites/default/files/research/chant-financial-regulation-final.pdf

John Chant | March 2014

SIMULATED REPLACEMENT RATES FOR CPP REFORM OPTIONS

http://policyschool.ucalgary.ca/sites/default/files/research/milligan-cpp-options-final.pdf

Kevin Milligan and Tammy Schirle | March 2014 